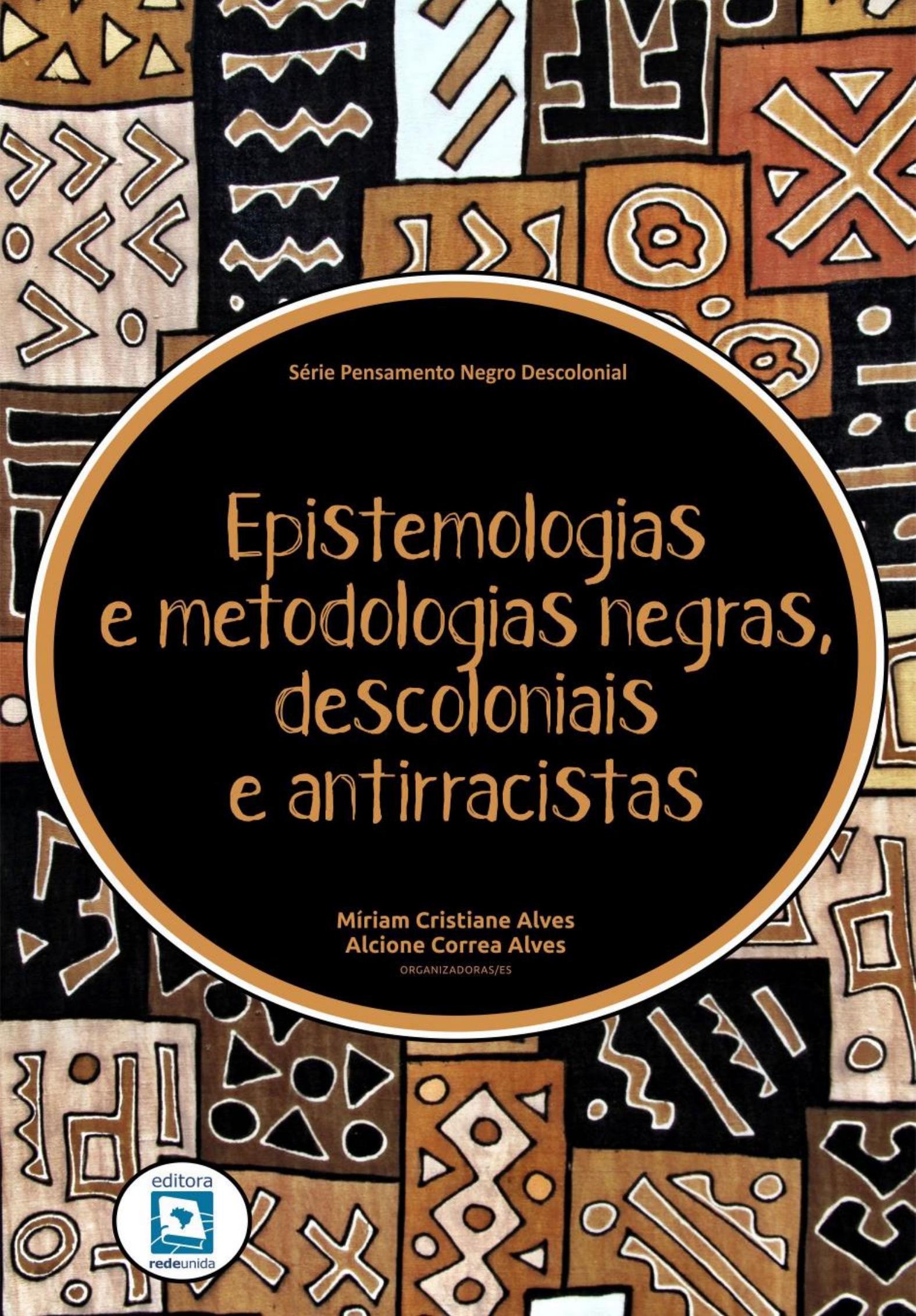


Míriam Cristiane Alves

Alcione Correa Alves

ORGANIZADORAS/ES

Série Pensamento Negro Descolonial

\section{Epistemologias e metodologias negras, descoloniais e antirracistas}

$1^{\text {a Edição }}$

Porto Alegre

2020

editora

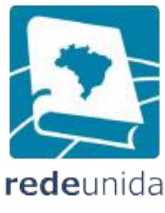


Comissão Executiva Editorial Márcia Regina Cardoso Torres

Coordenador Nacional da Rede UNIDA

Túlio Batista Franco

Coordenação Editorial

Editor-Chefe: Alcindo Antônio Ferla

Editores Associados: Gabriel Calazans Baptista, Ricardo Burg Ceccim, Cristian Fabiano Guimarães, Márcia Fernanda Mello Mendes, Julio Cesar Schweickardt, Sônia Lemos, Fabiana Mânica Martins

\section{Conselho Editorial}

Adriane Pires Batiston - Universidade Federal de Mato Grosso do Sul, Brasil;

Alcindo Antônio Ferla - Universidade Federal do Rio Grande do Sul, Brasil

Alexandre Ramos de Souza Florêncio - Organização Panamericana da Saúde, Nicarágua;

Àngel MartínezHernáez - Universitat Rovira i Virgili, Espanha;

Angelo Stefanini - Università di Bologna, Itália;

Ardigó Martino - Universita di Bologna, Itáli

Berta Paz Lorido - Universitat de les Illes Balears, Espanh

Celia Beatriz Iriart - University of New Mexico, Estados Unidos da América;

Denise Bueno - Universidade Federal do Rio Grande do Sul, Brasil;

Emerson Elias Merhy - Universidade Federal do Rio de Janeiro, Brasil;

Erica Rosalba Mallmann Duarte - Universidade Federal do Rio Grande do Sul, Brasil;

Francisca Valda Silva de Oliveira - Universidade Federal do Rio Grande do Norte, Brasil

Izabella Barison Matos - Universidade Federal da Fronteira Sul, Brasil;

Hêider Aurélio Pinto - Universidade Federal do Recôncavo da Bahia, Brasil;

João Henrique Lara do Amaral - Universidade Federal de Minas Gerais, Brasil;

Juleimar Soares Coelho de Amorim - Instituto Federal de Educação, Ciência e Tecnologia do Rio de Janeiro, Brasil;

Júlio César Schweickardt - Fundação Oswaldo Cruz/Amazonas, Brasil;

Laura Camargo Macruz Feuerwerker - Universidade de São Paulo, Brasil;

Laura Serrant-Green - University of Wolverhampton, Inglaterra;

Leonardo Federico - Universidad Nacional de Lanús, Argentina;

Lesiane Böer Possa - Universidade Federal de Santa Maria Basi;

Liliana Santos - Universidade Federal da Bahia, Brasil;

Luciano Bezerra Gomes - Universidade Federal da Paraíba, Brasil;

Mara Lisiane dos Santos - Universidade Federal de Mato Grosso do Sul, Brasil;

Márcia Regina Cardoso Torres - Secretaria Municipal de Saúde do Rio de Janeiro, Brasil;

Marco A

Maria Luiza Jaeger - Associação Brasileira da Rede UNIDA, Brasil

Maria Luiza Jaeger - Associação Brasileira da Rede UNIDA, Brasil;

Maria Rocineide Ferreira da Silva - Universidade Bs

Paulo de Tarso Ribeiro de Oliveira - Universidade Federal do Pará, Brasil;

Paulo de Tarso Ribeiro de Oliveira - Universidade Federal do Para, Brasil;

Ricardo Burg Ceccim - Universidade Federal do Rio Grande do Sul, Brasil;
Rodrigo Tobias de Sousa Lima - Fundacão Oswaldo Cruz/Amazonas, Brasil

Rodrigo Tobias de Sousa Lima - Fundação Oswaldo Cruz/Amazonas,
Rossana Staevie Baduy - Universidade Estadual de Londrina, Brasil;

Rossana Staevie Baduy - Universidade Estad

Simone Edi Chaves - Ideia e Método, Brasil;

Sueli Terezinha Goi Barrios - Ministério da Saúde, Brasil;

Túlio Batista Franco - Universidade Federal Fuminense, Brasil;

Vera Lucia Kodjaoglanian - Fundação Oswaldo Cruz/Pantanal, Brasil;

Vera Maria Rocha - Associação Brasileira da Rede UNIDA, Brasil.
Lucia Pouchain

ISSN: 2446-4813
Avaliadoras/es

Alcione Correa Alves - UFP

Jean-Bosco Kakozi Kashindi - UNIL

Livia Mara Natália de Solza - UFBA

Mirian Cristane Alves - UTPE/ PPGPSI-UFRGS

Raquel da Silva Silveira - UFRGS

Rutte Tavares Cardoso Andrade - UNILAB

\section{DADOS INTERNACIONAIS DE CATALOGAÇÃO NA PUBLICAÇ̃̃O-CIP}

E64 Epistemologias e metodologias negras, descoloniais e antirracistas / Míriam Cristiane Alves, Alcione Correa Alves, organizadoras/es. -1. ed. - Porto Alegre : Rede UNIDA; 2020 213 p. - (Série Pensamento Negro Descolonial)

ISBN: 978-85-54329-36-5

DOI: $10.18310 / 9788554329365$

1. Colonialismo. 2. Fatores Raciais. 3. Grupo com Ancestrais do Continente Africano 4 . Comportamento e Mecanismos Comportamentais. 5. Características do Estudo 6 Racismo. I. Alves, Míriam Cristiane (org.). Il. Série.

NLM: H 71

Catalogação elaborada pela Editora Rede UNIDA

Todos os direitos desta edição reservados à Associação Brasileira Rede UNIDA Rua São Manoel, nº 498 - CEP 90620-110, Porto Alegre - RS. Fone: (51) 3391-1252

\section{www.redeunida.org.br}

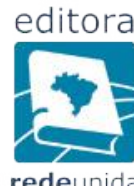


Deivison Faustino

Apresentação

Míriam Cristiane Alves e Alcione Correa Alves

Escritura, representación y colonialidad. Una hipótesis de trabajo a partir de Fanon

Colonialidade da sexualidade: dos conceitos "Clássicos" ao pensamento crítico descolonial.

Tatiane Borchardt da Costa e Miriam Cristiane Alves

As cores do afeto: um ensaio sobre as mulheres negras no contexto das relações afetivas

Andréa Franco Lima e Silva

Potências auto-antropológicas: reflexões de uma estudante negra sobre teorias antropológicas contemporâneas... Aline de Moura Rodrigues

Escrevivências sobre cuidado ao usuário de álcool e outras drogas: diálogos entre redução de danos e pensamento descolonial

Marina Tremper, Míriam Cristiane Alves e Károl Veiga Cabral

A arte de trazer a vida pelas mãos

Diálogo com bell hooks: reorientação da formação em saúde a partir da perspectiva negra decolonial 
Abaixa a guarda e abre o peito: o resgate físico, cognitivo e subjetivo do sujeito negro no Slam Chamego ... 159 Fernanda Maiato, Maíne Alves e Rafael Barcellos

Contribuições à reflexão afrocêntrica: aprendizagens matricentrais em processos de longa duração. 176 Jefferson Olivatto da Silva, Márcia Denise de Lima Dias e Thais Rodrigues dos Santos

Urbanização e resistência na África contemporânea: itinerários da ocupação urbana e a colonização em Cabo Verde. 190 Rutte Tavares Cardoso Andrade

Sobre as autoras e os autores 210

\section{PREFÁCIO}

Deivison Faustino

"No princípio era o Verbo, e o Verbo estava com Deus, e o Verbo era Deus” (João, 1:1-5 - Bíblia Cristã)

"o ferreiro forja a Palavra, o tecelão a tece e o sapateiro amacia-a curtindo-a” (Hampatê Ba, 2010)

De acordo com a cosmovisão Dogon - povo que vive nas Falésias do Bandiagara, Mali - a divindade Amma gerou o universo a partir de um sopro sagrado original que permanece ecoando em espiral no tempo e no espaço que nos circunda ${ }^{1}$. Para esta cultura, a fala não se limita a um ato singular do indivíduo em seu intento de transmitir determinados signos, mas a uma ação criativa sagrada que transforma o mundo material e espiritual a partir da manutenção do hálito divino original que gerou a vida no mundo.

No mesmo caminho, o etnólogo malinês Amadou Hampatê Ba fala da tradição bambara do Komo - uma grande escola de iniciação Mandê - onde se ensina que Kuma (palavra) é uma força fundamental que emana do criador supremo, Maa Ngala². Nesta tradição, Ma (o Ser humano), eleito pelo Criador como Guardião do Universo, recebera como herança divina o dom da mente e da palavra, permitindo-lhe manter a harmonia universal.

Assim como na mitologia Dogon, o ato de falar, para os bambara, nos conecta a uma universalidade cósmica sagrada a partir da incorporação, em escala menor, do ato divino da criação. É interessante notar aqui a inexistência de um conjunto de dicotomias hierárquicas fartamente presentes na cosmovisão helênica, e, em consequência, nos mitos de criação judaico-cristãos. Me refiro às dicotomias entre o sagrado (deus) e o profano (Humano); o corpo e a alma; a razão e a emoção; o inteligível e o sensível e, sobretudo, a dicotomia entre a teoria e prática, a partir de uma matriz de pensamento onde a concepção da ação e a fala pertence aos Senhores enquanto os escravos, meros instrumentos animados. 1 Ver: DIAGNE, Mamoussé, 2005, Critique de la raison orale. Les pratiques discursives en Afrique noire, Paris, Karthala, $600 \mathrm{p}$.

2 Ver: BÃ, A. Hampaté. A tradicão viva. KI-ZERBO, Joseph. História geral da África, I: Metodologia e pré-história da África. 2. ed. rev. - Brasília: UNESCO, 2010. 
Para as cosmovisões Bambara e Dogon, ao contrário, o sujeito que pensa e fala é o mesmo que produz e a produção, por sua vez, o momento onde o sagrado fala a partir dos gestos criativos e ritmados do produtor. Assim a fala, enquanto vivificação da palavra divina, é “a materialização, ou a exteriorização, das vibrações das forças" 3 . Como revela um canto tradicional expresso por Hampaté Ba, “o ferreiro forja a Palavra, o tecelão a tece e o sapateiro amacia-a curtindo-a"4.

A semelhança entre tradições e os mitos de criação judaico-cristãos parece evidente, quando a comparamos com o livro de João I da Bíblia onde o Verbo é deus. Ocorre que nas culturas africanas supracitadas, esse Verbo não está fora e em oposição ao humano, mas existe também através de sua fala. A fala, portanto, não é apenas algo que nos humaniza, mas sim, a manifestação de deus em Nós.

Se a fala é sagrada, como sugerem os mitos acima aludidos, a pergunta que se pode fazer diante do instigante desafio de apresentar a Série Pensamento Negro Descolonial: Epistemologias e Metodologias Negras, Descoloniais e Antirracistas é: quem, de fato tem o poder e a prerrogativa da fala em uma sociedade forjada estruturalmente pelo colonialismo e a escravidão? Esta pergunta não é nova nas ciências sociais e humanas contemporâneas e, recentemente, se fez notar com a teórica literária e crítica feminista Gayatri Chakravorty Spivak a partir de seu ensaio intitulado Pode o subalterno falar? ${ }^{5}$ escrito originalmente em 1985.

No ensaio Spivak denuncia a posição etnocêntrica implícita no culto cânones de intelectuais do ocidente, como Michel Foucault e Gilles Deleuze. A denúncia oferecida por ela constata que mesmo nas tradições teóricas críticas ocidentais protagonizadas, em geral, por homens brancos do norte global - a alteridade (o outro, subalternizado) só existe enquanto objeto da produção de conhecimento. $\mathrm{E}$ como tal, enjaulados em uma alteridade essencial e intransponível, os subalternos dependeriam sempre da benevolência de pesquisadores hegemônicos para terem a sua existência reconhecida. Diane dessa violência epistêmica, a autora se pergunta: Pode o subalterno falar? Ou seja, se a fala é postulado divino em ato de criação, quem tem a prerrogativa de falar e ter sua sagrada existência reconhecida?

Quase quatrocentos anos antes, o dramaturgo inglês William Shakespeare levantara uma questão semelhante em sua peça de teatro escrita no Ba, 2010, p. 172.

Spivak, Gayatri Chakravorty. Pode o subalterno falar? Tradução de Sandra Regina Goulart Almeida, Marcos Pereira Feitosa e André Pereira Feitosa. Belo Horizonte: Editora UFMG, 2010. início do século XVII intitulada The Tempest ${ }^{6}$ ao descrever a personagem Caliban único habitante de uma ilha "deserta" e filho de uma bruxa africana - como "escravo selvagem e disforme". Se todo escravo é um objeto mudo de alguém, o verdadeiro sujeito da estória é a personagem Próspero, um Duque feiticeiro europeu que chegara na ilha e a colonizara para empreender um plano geopolítico contra adversários europeus, mas não sem antes, tomar o nativo Caliban como escravo. No diálogo entre o colonizador Próspero e sua filha Miranda, onde a personagem Caliban é apresentado pela primeira vez na peça, lê-se a seguinte descrição:

Próspero - Vamos visitar Caliban, o meu escravo, que nunca nos dá uma resposta amável.

Miranda - E um vilão, Senhor, para quem eu não gosto de olhar.

Próspero - Mas mesmo assim não podemos dispensá-lo: é ele que acende o nosso fogo, vai buscar a nossa lenha, e serve-nos em tudo o que nos faz falta. Ei! Escravo! Caliban! Tu, terra! Tu, fala! (v. 307-314) ${ }^{7}$.

Spivak alertou em seu "pode o sulbalterno falar" a respeito da violência epistêmica colonial que permite o direito à fala apenas ao homem branco cisgênero e heterossexual, mesmo quando a fala é uma crítica social. Mas a provocação de Shakespeare parece ser ainda mais perturbadora quando se constata que o próprio Próspero permite que seu servo Caliban fale, aliás, o ordena, desde o faça quando lhe for conveniente. A questão, portanto, não se reduz à possibilidade ou não de fala mas, precisamente, no naquilo que se fala e em quais condições.

Dito de outro modo, a violência epistêmica pode estar presente mesmo quando o subalterno fale, caso as condições de subalternidade não se lhe permita dizer o que de fato convém, em seus próprios termos, ou, pior que isso, quando as próprias regras da linguagem, "impostas, não propostas pelo poder de canhões e sabres" são exógenas aos significados e desejos em jogo. Trata-se de uma imposição política de um conjunto de signos que não apenas restringe a fala do colonizado, mas, também, o mantém em seu lugar. Como lembra Próspero diante

$\overline{6}$ Shakspeare, William, The tempest. Noston, W. W. \& Company, Inc. Second. Edition. 2019 [1610]. 7 Shakspeare, William, apud CENTENO, Y. K. Shakspeare: Caliban ou as fulgurações da linguagem Imateriais de trabalho). HVMANITAS. Vol. XLVII, 1995.

8 Fanon, Frantz, Racismo e cultura. In: Em defesa da revolução africana. Lisboa: Sá da Costa, 1969. P. 38 
da ameaça de insubmissão de Caliban: "quando tu, selvagem, não conhecias o teu próprio sentido, e andavas por aí tagarelando como um bruto, fui eu que atribuí palavras aos teus desejos, para os poderes exprimir" 9

Não seria exatamente este o dilema que os povos colonizados da África, América e Ásia vão enfrentar diante da universalização das relações capitalistas de produção, levada a cabo pelas potências coloniais europeias nos últimos quinhentos anos? Assim como Caliban, os povos colonizados viram suas culturas, epistemes e crenças serem incorporadas e apropriadas pelos colonizadores - quando esses conhecimentos convinham à dinamização da produtividade escravista - ${ }^{10}$ ou desmanteladas e estigmatizadas diante de uma nova ordem social que se impunha a partir de crenças, teorias, mitos, signos e armas que afirmavam a pretensa superioridade natural, social e espiritual dos europeus. Como recusar radicalmente esse repertório se até a língua sobre o qual o pensamento se consolida, é a língua do colonizador? Poderiam as ferramentas do opressor derrubar as estruturas da casa grande? ${ }^{11}$

A Série Pensamento Negro Descolonial. Epistemologias e Metodologias Negras, Descoloniais e Antirracistas, que o leitor tem em mãos, oferece interessantes aportes a esse dilema. Em primeiro lugar porque o conjunto de artigos aqui apresentados, embora adotem caminhos e referencias teóricos diversos, apontam acertadamente para a existência de uma colonialidade racial e sexual que atravessa a produção de conhecimento contemporâneo, mesmo em expressões assumidamente críticas. Em segundo lugar, porque propõe saídas bastantes frutíferas e instigantes para fazer frente à essa colonialidade tanto no plano acadêmico, quanto nas dimensões éticas, políticas e estéticas.

Voltando à problemática da fala, os artigos aqui apresentados contribuem para refletirmos sobre duas questões perturbadoras: Em primeiro lugar, quem tem o privilégio de ser reconhecido como subalterno e, portanto, legitimado a falar sobre o silenciamento epistêmico? Em segundo lugar, se a expressão epistêmica da colonização não se reduz à possibilidade da fala, mas, sobretudo,

$9 \quad$ Op. cit. Shakspeare, William, apud CENTENO.

10 Na peça, Caliban recebe Próspero de maneira xenofílica e lhe apresenta a ilha e os seus segredos que até então dominava. Ver: Shakspeare, William, The tempest. Op. cit.

11 Pergunta baseada na afirmação taxativa de Audre Lorde "As ferramentas do senhor jamais irão desmantelar a casa grande" Lorde, Audre. "For the master's tools will never dismantle the master's house" in: Histoy is eapon. ao controle do que, como e quando as coisas podem ser ditas, o que seria uma rebeldia epistêmica autêntica?

Em relação à primeira pergunta, a cientista social Larissa Pelúcio lança uma provocação bastante interessante ao denunciar a presença de uma certa colonização anglo-saxã nos estudos contemporâneos sobre subalternidades. Para ela há um conjunto de particularidades históricas-culturais, mas também de insurgências políticas e epistêmicas que se perdem quando pensamos o antirracismo, o feminismo e a teoria Queer apenas a partir das lentes críticas que emergem sob o solo e a legitimidade do Norte Global. Notemos que a crítica da autora não é à validade ou não dessas epistemes, mas aos limites - nem sempre equacionados - que elas podem oferecer ao serem aplicadas mecanicamente à outros contextos socio-culturais como a Améfrica Ladina, por exemplo ${ }^{12}$.

É neste contexto onde a subalternidade escrita ou falada em inglês, a partir da inserção de seus formuladores em universidades renomadas do centro capitalista, tem infinitas chances a mais de circular mundialmente que Pellúcio lança a pergunta: Subalterno quem, cara pálida? Será que as insurgências que não fazem referência aos cânones (em geral, anglófonos) das subalternidade, aquelas que não se adequam às normas ocidentais acadêmicas ou aquelas que não foram escritas na língua franca do capitalismo contemporâneo, também terão o mesmo poder de projeção e circulação nos espaços de formação e produção de conhecimento? O livro que o leitor tem em mãos oferece instigantes apontamentos à essa questão.

A segunda pergunta, relacionada a quem, o que, quando e como se fala é respondida nesta coletânea de maneiras muito diversas. Devo reconhecer que este é seu maior mérito, uma vez que consegue acolher perspectivas teóricas e políticas distintas e, em disputa ou negociação no campo do antirracismo. A resposta de Caliban a essa pergunta - e acredito que também de Frantz Fanon, Patrice Lumumba, Angela Davis, Beatriz Nascimento, Lélia Gonzales, entre outres - foi

12 Em seu artigo, Pelúcio coloca essa questão da seguinte maneira: "ossa drag, por exemplo, não é a mesma do capítulo 3 do Problemas de Gê-nero de Judith Butler (2003), nem temos exatamente as drag king das oficinas de montaria de Beatriz Preciado, ou sequer podemos falar de uma história da homossexualidade do mesmo modo de David M. Halperin, ou da Aids como o fez Michel Warner. Nosso armário não tem o mesmo "formato" daquele discu- tido por Eve K. Sedgwick. Cito aqui o quinteto fantástico do queer. Ainda que entre nós alguns
nomes sejam mais familiares que outros, foi essa a bibliografia que chegou com mais força até nós a partir do ternomes sejam mais familiares que outros, foi essa a bibliografia que chegou com mais força até nós a partir do ter-
ritório queer euro-americano". Pelúcio, Larissa. Subalterno quem, cara pálida? Apontamentos às margens sobre ritório queer euro-americano.
pós-colonialismos, feminismos estudos queer. Contemporânea, Salvador, vol. 2, no 2, 2012, pp.395-418 p. 413 
a de não se furtar à linguagem e referenciais teóricos validados pelo colonizador, mas sim, toma-las para si, utilizando-a em seus próprios termos, como afirma Caliban usando a linguagem do colonizador para manda-lo à merda: "Ensinasteme a falar e a minha vantagem foi que aprendi a (lhe) amaldiçoar"13

Ciente dessa poderosa insurgência, Jean Paul Sartre, no prefácio da Antologie de la poésie nègre et malgache de Léopold Sedar Senghor (1948), ao tomar contato com o movimento anticolonial que se gestava sob o signo francês da Négritude, avisou aos europeus o que estaria por vir quando os milhões de Calibans se insurgissem:

O que vocês esperavam que acontecesse quando tiraram a mordaça que tapava essas bocas negras? Esperavam que elas lhes lançassem louvores? E essas cabeças que seus avós e seus pais haviam dobrado à força até o chão? O que esperavam? Que se reerguessem com adoração nos olhos? Ei-los em pé. Homens que nos olham. Ei-los em pé. Faço votos para que vocês sintam como eu a comoção de ser visto ${ }^{14}$ (Sartre, 1968, p. 89)

Esses levantes balançaram irreversivelmente o mundo colonial, no século XX, ao promover transformações, ressignificações, decodificações das mais diversas, mas também, abrindo as portas para contradições e ambiguidades identitárias - e por vezes, totalitárias - jamais pensadas. Este movimento transnacional afro-diaspórico de libertação anticolonial está na raiz política e teórica de movimentos como os Black Panthers, dos EUA da década de 1960 e na teoria da afrocentricidade, proposto pelo estadunidense Molefi Asante, na década de 1980, no Movimento Negro Unificado Contra a Discriminação Racial, surgido em 1978 em plena ditadura militar brasileira e nos movimentos de mulheres negras que surgem de forma independente em vários países americanos a partir da década de 1980.

Esses movimentos foram pautados, incialmente por uma certa ideia de identidade, mas também de relação com epistemes críticas que circulavam hegemonicamente nestes contextos como o marxismo, o nacionalismo ou o feminismo. Essas perspectivas, embora reconhecidas em suas contribuições $13 \quad$ Op. cit. Shakspeare, William, apud CENTENO.

14 SARTRE, Jean Paul. Précédée de Orphée noir par Jean-Paul Sartre, anthologie de la nouvelle poésie nègre et malgache de langue française [1948]. In: SARTRE, Jean Paul. Reflexões sobre o racismo. Difusão europeia gre et malgache de la
do livro, 1960. P. 89 históricas, serão duramente criticadas, a partir da década de 1980, pelo então emergente pensamento pós-colonial. A visível influência estruturalista ${ }^{15}$ e pósestruturalista ${ }^{16}$ desta perspectiva político-teórica, mas também a sua vinculação, de um lado, com os estudos subalternos e, do outro, com os estudos culturais e a nova esquerda britânica ${ }^{17}$ os municiou para fazer uma crítica às noções essencialistas de identidade e sujeito, presentes nos movimentos anticoloniais, bem como à ausência da tematização do colonialismo nos cânones críticos europeus, para então, apontar a centralidade de uma cultura, da gramatologia textual, da linguagem ou discurso colonial para a política contemporânea.

A partirdaí o pensamento pós-colonial passará a circular com bastante força - embora sempre às margens - na academia do norte global e, em consequência, em importantes espaços de produção de conhecimento nas periferias conectadas à essas matrizes. Neste processo, um grupo de intelectuais latino-americanos, bastante influenciados pela teoria da dependência ou pelas teoria do sistemamundo-capitalista se aproxima e se influencia por esse referencial, mas logo depois se afasta dele, em busca de uma identidade e referencias teóricos próprios, sendo conhecidos, posteriormente como Grupo Modernidade Colonialidade GMD ou pensamento decolonial.

Um dos pontos de cisão entre a teoria pós-colonial e o pensamento decolonial, segundo afirmam os protagonistas do segundo grupo, é a demasiada vinculação eurocêntrica do primeiro grupo aos cânones ocidentais do pós-estruturalismo e a ausência de uma reflexão sobre as insurgências ibero-americanas. Aliás, uma das principais apostas do grupo latinoamericano foi a constatação de que, não apenas a Europa criou a América, mas esta, ao ser criada em atos violentos de colonização, forjou também a Europa e o ocidente. Mais do que isso, esses pensadores lembrarão que enquanto os pensadores pós-coloniais focaram nas experiências de independência africanas, ocorridas em meados do século XX, ocultou-se o fato de que, as independências na América Latina ocorreram um século antes.

15 . Ver nesse sentido Dosse, F. História do estrturalismo São Paulo: Ensaio, 1993.

16 Me refiro especialmente a autores que nem sempre se consideravam ou são considerados pós-estruturalistas mas que protagonizaram uma crítica à identidade, ao sujeito e às meta-narrativas, como Michel Foucault, turalismo e a filosofia da diferença. Belo Horozonte. Autêntica, 2000. e Luc-Ferry J. e Renaut, A. Pensamento 68: turalismo e a filosofia da diferença. Belo Horozonte. Autêntica, 2000. e Luc-
ensaio sobre o anti-humanismo contemporâneo. São Paulo, Ensaio, 1988.

ensaio sobre o anti-humanismo contemporâneo. São Paulo, Ensaio, 1988.
$17 \quad$ Ver Hall artigo de da diaspora HALL, Stuart. "Quando foi o pós-colonial?" In: Da Diáspora: Identidades 17 Ver Hall artigo de da diaspora HALL, Stuart. "Quando foi o pós-colonial?" In: Da Diáspora: Identidades Brasília: Representação da Unesco no Brasil, 2003. 
Essa experiência singular do nosso continente é tomada como centro, por esses pensadores, para indagar que o fim do colonialismo não foi suficiente para romper com a colonialidade do ser, do poder e do saber ${ }^{18}$, que marcam a nossa configuração social. A partir daí, se iniciará uma série de esforços para visibilizar epistemes outrora ocultadas tanto pelo colonialismo, em sua expressão histórica, quanto pela permanência de longa duração do antigo ethos colonial, expressa, inclusive, pela aceitação apressada de epistemes insurgentes produzidos a partir do norte global. É nesta tradição que se situa a pergunta de Larissa Pelúcio à Spivak: "subalterno quem, cara pálida?"

Esta longa digressão tem como objetivo avisar ao leitor, tal como o fez Sartre no prefácio à Léopold Sédar Senghor, que não encontramos, na presente publicação, louvores à epistemes ocidentais, sejam elas críticas ou ordinárias. Há uma preocupação assumida em recuperar a possibilidade da fala, mas também disputar os termos pelo qual ela é legitimada. No entanto, como já afirmado, os caminhos pelo qual essa disputa se dá em cada artigo são bastante diversos e revelam as diferenças, tensões e negociações entre perspectivas teóricas como o feminismo, o feminismo negro, teoria da intereseccionalidade, o pensamento pós-colonial e o decolonial, entre outros.

No artigo que abre a coletânea, intitulado "Escritura, Representación e Colonialidad: una Hipótesis de Trabajo e Partir de Fanon", de Alejandro De Oto temos logo de cara, um diálogo do autor com Fanon para pensar não apenas quem fala mas como se fala. Curioso que o autor inicia o artigo revelando o quanto a colonialidade do saber também marcou a sua formação como um pensador crítico e o quanto ainda se configura como um desafio não vencido à produção de conhecimento.

Já Alcione Correa Alves, em “A Teoria Literária Como Jogo" dá sequência às preocupações de Oto em um outro sentido ao tomar os Estudos Literários no Brasil como campo onde se estabelecem verdadeiros jogos de enunciação. $\mathrm{O}$ autor utiliza a ideia de uma "epistema centroeuropeu" ou "colonização discursiva" para falar da desumanização, invisibilidade imposta às mulheres negras, inclusive, muitas vezes, por narrativas contra-hegemônicas como o feminismo.

$18 \quad$ O conceito de Colonialidade do Poder, cunhado por Aníbal Quijano (2005) foi retomado e sofisticado, posteriormente, por outros autores do grupo resultando na tríade Colonialidade do Poder, do Ser e do Saber. posteriormente, por outros autores do grupo resultando na triade Colonialida
(MALDONADO-TORRES, 2007, CASTRO-GÓMEZ; GROSFOGUEL, 2007).
Para ele, questionar a atribuição naturalizada de papeis aos sujeitos-em-jogo é a possibilidade das "Pretas" não apenas jogarem os jogos impostos mas também definirem os seus termos.

Num outro caminho Tatiane Borchardt da Costa e Miriam Cristiane Alves, em seu artigo sob o título de "Colonialidade da Sexualidade: dos Conceitos "Clássicos” ao Pensamento Crítico Descolonial” apresentam a seguinte pergunta: "Quem é o Humano no Conceito "Clássico" da Sexualidade Humana?" A partir daí, retomam as noções de colonialidade do Poder, do Ser e do Saber para pensar no quanto as estruturas de poder da modernidade/colonialidade, fundadas a partir da ideia de raça e gênero, imprimem uma apreensão hierarquizada do humano e da sexualidade que deixam de fora a experiência negra e outras geografias periféricas em contextos de racialização.

Em "As Cores do Afeto: um Ensaio Sobre as Mulheres Negras no Contexto das Relações Afetivas", Andréa Franco Lima e Silva apresenta um ensaio que coloca em tela as questões de afetividade e solidão das mulheres negras. Para tal, propõe um olhar sociológico para este público que nos permita avançar para além da descrição e seus lugares nos indicadores sociais dando visibilidade à sua subjetividade em uma sociedade racializada. Por outro lado, Aline de Moura Rodrigues em "Potências Auto-Antropológicas: Reflexões de Uma Estudante Negra Sobre Teorias Antropológicas Contemporâneas" propõe uma escrevivência da própria trajetória que nos convida a romper o silenciamento e a invizibilidade imposta às mulheres negras que chegam à academia.

Marina Tremper, Míriam Cristiane Alves, Károl Veiga Cabral, por sua vez, em "Escrevivências sobre Cuidado ao Usuário de Álcool e Outras Drogas: Diálogos Entre Redução de Danos e Pensamento Descolonial” lançaram mão do referencial teórico decolonial para apresentar uma escrevivencia do cuidado, pautado pela $\mathrm{RD}$ em direção ao que denominam "espaço de compreensibilidade mútua entre vivências, experiências e saberes diferentes que se encontram nos territórios, no tecido social".

Em um caminho semelhante, mas com vistas aos desafios da formação e educação permanente em saúde, Dyana Helena de Souza propõe um "diálogo com bell hooks: reorientação da formação em saúde a partir da perspectiva negra decolonial”. O texto, ao relatar uma experiência de diálogo pedagógico e 
epistêmico antirracista em uma disciplina de pós-graduação em Saúde Coletiva e criticar os limites bancários e conteudistas de certas abordagens, problematiza a importância reconhecer a centralidade da equidade racial no processo ensinoaprendizagem em saúde.

Já Mirian Teresa de Sá Leitão Martins em “A Arte de Trazer a Vida Pelas Mãos” fala das magias e os perigos envolvidos no ato de partejar. Pautada por uma crítica à biopolítica implícita na institucionalização das funções relacionadas ao parto, pela medicina moderna e a consequente desqualificação das práticas e saberes populares referentes ao partejar. A autora aborda os saberes tradicionais e também modernos - sobre a guarda dessas mulheres.

$\mathrm{O}$ artigo seguinte, intitulado "Abaixa a Guarda e Abre o Peito: O Resgate Físico, Cognitivo e Subjetivo do Sujeito Negro no Slam Chamego" de Fernanda Maiato, Maíne Alves e Rafael Barcellos aborda como a temática do afeto e da sexualidade aparecem em espaços culturais insurgentes organizados por jovens negros de periferia. Ao apontar provocativamente que "Os resistentes também amam" provocam-nos a pensar o amor e a sua tematização como forma de resistência política.

Num caminho bastante distintos dos anteriores, mas não sem um diálogo e influência recpíproca, Jefferson Olivatto da Silva, Márcia Denise de Lima Dias e Thais Rodrigues dos Santos apresentam o ensaio "Contribuições à Reflexão Afrocêntrica: Aprendizagens Matricentrais em Processos de Longa Duração". O texto, fortemente embasado no referencial teórico da afrocentricidade, retoma os Estudos de Cheikh Anta Diop, Molefi Kete Asante e Wade Nobles para problematizar a experiência de desencarrilhamento social, cultural e subjetivo que a escravidão provocou para em seguida proporem o retorno aos sistemas matricentrais, ou seja, de cuidado, afeto, confiança, compromisso, respeito e proximidade, presentes na cultura africana.

No mesmo caminho, Rutte Tavares Cardoso Andrade, em seu "Urbanização e Resistência na África Contemporânea: Itinerários da Ocupação Urbana e a Colonização em Cabo Verde" encerra a coletânea ao tomar a teoria da afrocentricidade como referencial teórica para problematizar as lógicas implícitas à urbanização de Cabo Verde, promovida em um contexto de dominação e de exploração colonial. Para ela, os esforços governamentais de promoção de habitação e trabalho, neste país, têm sido ineficazes ao não dialogar com as necessidades e os princípios de coletividade e protagonismo social das mulheres caboverdianas.

Em síntese, encontrar-se-á aqui algumas contribuições de grande valor aos estudos contemporâneos sobre a cultura, identidade e identificação. Mais do que isso, os textos aqui reunidos acabam se configurando como um posicionamento teórico e político relevante diante da dimensão epistêmica da violência colonial, a colonialidade do saber ao apontar a possibilidade do subalterno falar através caminhos mais diversos. Como dizia o militante estadunidense Stokely Carmichael, fundador do Black Power e antecipador teórico do usual slogam "nós por nós": "temos que lutar para ter o direito de inventar os termos que nos permitirão definir a nós e à nossa relação com a sociedade, e temos que lutar para que esses termos sejam aceitos".

O grande desafio apresentado por Frantz Fanon ${ }^{19}$, há 70 anos, quando ele tinha vinte e quatro anos de idade e escrevia o seu TCC para a graduação em psiquiatria, é que a necessária afirmação do Nós - presente no "nós por nós" - em um contexto de subalternização depende da aceitação e interiorização, a priore, das barreiras identitárias que Eles - quem se privilegiam da subalternidade - nos impuseram em benefício de seus interesses. Isso significa que qualquer afirmação do Nós, mesmo que subversiva à ordem em sua inversão radical dos termos da oração, é sempre também a afirmação Deles, seguida pela rejeição de tudo o que é Deles em benefício da afirmação incondicional de tudo o que é "Nosso".

O problema é que se o limite entre "o nossos" e "o deles" foi criado por Eles (e em benefício deles). A afirmação político-identitária do que se entende por nosso, portanto, caso aceite os limites criados por eles, corre o risco de deixar para eles aquilo que também é nosso, mas sempre foi apresentado por eles como deles. Neste caso, o Caliban, em seu grito mais insubmisso, abriria mão da linguagem de Próspero, recusando as ferramentas do opressor, e com isso, perderia a chance de amaldiçoa-lo em um contexto social em que língua colonial é a única fonte de comunicação que conecta o emissor e o receptor ${ }^{20}$.

$19 \quad$ Fanon, F. Pele negra, máscaras bracas. Salvador ed. Editora EDUFBA, 2008.

20 Tenho abordado essa questão em outros lugares: Faustino, D. A emoção é negra e a razão é helênica? Considerações fanonianas sobre a (des) universalização do. Revista Tecnologia e Sociedade (on-line), v. 1, 2013, DO II COLOQQUIO INTERNACIONAL SOBRE SARTRE: interseccionalidades na compreensão do sujeito con- 
O que estou tentando chamar a atenção é que, se os Dogon e os Bambara estiverem corretos e as falas de cada falante singular foram manifestação de algo que os transcende, a noção de "nós" poderia ser muito mais ampla do que aquelas definidas pelo colonizador - aquilo que escapa à noção branquitude hetero-patriarcal -, talvez, se não fosse a colonização, o "nós" remeteria a toda a humanidade e esta mesma, pensada em sua relação simbiótica com os outros seres vivos e com o universo como um todo e não apenas à sua parte subalternizada.

Para Fanon essa consciência ampliada do "Nós" não se alcança por decreto ou negação verbal das diferenças concretas historicamente criadas pelo colonialismo e nem pelo simples direito de falar mas sim, pela luta de vida e morte do colonizado em busca de sua emancipação e construção de condições sociais, econômicas e políticas igualitárias para a fala. Ocorre que se essa luta violenta não for acompanhada por aquilo que ele chamava de "novo humanismo" - ou seja, uma consciência de que o "nós" de fato está para além desse "nós" restrito que não podemos abrir mão de afirmar - ela corre o risco de, mesmo buscando falar em seus próprios termos, aceitar como próprio aquilo que seu algoz lhe impôs.

Mas como, para Fanon, não é possível ascender a esse "Nós" ampliado apenas "apelando à razão" abstrata mas, sim, pela afirmação radical daquilo que foi negado ou invisibilizado em nome de um projeto colonial de cunho universalista, a luta pela auto-definição se faz necessária e fundamental. É por isso que uma publicação como a Série Pensamento Negro Descolonial. Epistemologias e Metodologias Negras, Descolonias e Antirracistas é tão importante.

temporâneo - UEM/Maringá/PR - 30 de Setembro a 02 de Outubro, 2019
APRESENTAÇÃo

Míriam Cristiane Alves Alcione Correa Alves

Enquanto obra tributária das três edições das Jornadas do Núcleo de Estudos e Pesquisa É'LÉÉKO já realizadas ${ }^{21}$, esse primeiro volume da Série Pensamento Negro Descolonial apresenta produções autorais com narrativas de intelectuais, em sua maioria pesquisadoras/es negra/os, tendo como centralidade a insurgência de epistemologia e metodologias negras no campo das ciências humanas e da saúde. Além da insurgência, quiçá poderíamos considerar, igualmente, a necessidade (em um sentido metafísico ocidental, de algo somente possível de um único modo, específico) de tais epistemologias a nosso campo: da necessidade de propor, estabelecer e difundir uma ciência negra a se enunciar desde seu lugar negro, com todas as decorrências desta escolha política. Os anos mais recentes desta década nos têm desenhado um esforço conjunto de publicação de obras e traduções fundamentais neste sentido, ao que buscamos nos somar com esta primeira publicação da Série.

Em referência a este conjunto de publicações, pensemos, apenas a título ilustrativo, na publicação dos volumes do pensamento de bell hooks em português brasileiro, pela Editora Elefante, em 2019 (constando dentre os volumes já publicados, por exemplo, Olhares negros e Anseios); a publicação de traduções, em português brasileiro, de referências negras estadunidenses como Irmã Outsider: ensaios e conferências, de Audre Lorde (Autêntica), A origem dos outros: seis ensaios sobre racismo e literatura, de Toni Morrison (Companhia das Letras), além de Pensamento feminista negro, de Patricia Hill

$21 \quad$ As Jornadas do Núcleo de Estudos e Pesquisas ÉLÉÉKO têm se destacado, desde sua primeira edição, em 2017, como um evento acadêmico de discussões epistemológicas e formação de novas redes acadêmicas negras sob um eixo, o antirracismo. Se, em sua primeira edição (ate o momento, todas realizadas nas dependências da

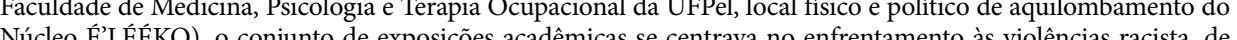
gênero de possibilidade a epistemologias e metodologias descoloniais antirracistas; uma vez mais, o antirracismo ao centro, assim como um marco de pensamento descolonial negro enquanto base comum a nossas somas de esforços tro, assim como um marco de pensamento descolonial negro enquanto base consér assas sonas de esforços científicos nestes três anos de evento e, doravante, neste primeiro volume de nossa Série. Importante salientar que esse primeiro volume é fruto de um projeto realizado pela Núcleo ÉLÉÉKO em parceria com a Rede Nacional de Social da Secretaria de Gestão Estratégica e Participativa do Ministério da Saúde (DAGEP/SGEP/MS). 
Collins (Boitempo). Quando a este contexto nos buscamos, nos referimos e nos fazemos sintoma de redes intelectuais negras em movimento, ao qual vos convidamos mediante leitura e apropriação deste primeiro volume de nossa Série.

O volume ora apresentado, assim como o conjunto da Série Pensamento Negro Descolonial, busca reunir diferentes perspectivas teóricas e políticas em torno de um eixo, o antirracismo, cujos deslocamentos, desdobramentos e agenciamentos epistêmicos têm o intuito de estimular reflexões sobre nossos usos e interpretações de matrizes do pensamento negro, assim como sobre a necessidade de formação de novas redes intelectuais na produção do conhecimento. Cabe a nós, nesta apresentação da obra, assinalar o caráter político de tal escolha (o antirracismo como nossa constante), assim como uma premissa a congregar, em distintos níveis, o conjunto de textos deste primeiro volume: o lugar de epistemologias e metodologias negras em nossas produções e difusões de conhecimento. Desde publicada a tradução, em português brasileiro, de Introdução a uma poética da Diversidade (Editora da UFJF, 2005), um público mais amplo passara a recorrer ao pensamento de Édouard Glissant para, a partir dele, apre(e)nder a ideia de que o lugar importa, isto é, o lugar desde o qual produzimos e difundimos conhecimento; o lugar desde o qual compreendemos e enunciamos o mundo, assim como o lugar desde o qual escutamos e apre(e)ndemos os lugares outros deste mesmo mundo - a gama de lugares possíveis no Tout-monde: a palavra não se enuncia no ar, em uma perspectiva ocidental de transcendência, mas se enuncia desde e para seu lugar no mundo ${ }^{22}$.

Disso se trata este primeiro volume, bem como o conjunto da Série Pensamento Negro Descolonial: enunciar desde um lugar negro descolonial, em busca de aprendizados e conhecimentos coletivos, à luz de epistemologias e metodologias às quais o lugar importa.

22 Sobre a ideia de lugar, do que decorreria o princípio da importância do lugar na produção, validação e difusão de conhecimento à luz de epistemologias negras: GLISSANT, 2005; HILL COLLINS, 2019, p. 401-432; sobre o desenho deste problema epistemológico: ALCOFF, 2016. Sobre a necessidade de compreensão e estabelecimento de marcos epistemológicos a uma produção, validação e difusão de conhecimento desde nossos lugares 2010, p. 65; CURIEL, 2019, p. 48).

\section{Referências}

HILL COLLINS, Patricia. Epistemologias negras feministas. Pensamento feminista negro. Tradução de Jamille Pinheiro Dias. São Paulo: Boitempo, 2019, p. 401-432.

GLISSANT, Édouard. Introdução a uma poética da diversidade. Tradução de Enilce do Carmo Albergaria Rocha. Juiz de Fora: Editora da UFJF, 2005.

hooks, bell. Olhares negros: raça e representação. Tradução de Stephanie Borges; revisão técnica de Rosane Borges. São Paulo: Elefante, 2019.

. Anseios: raça, gênero e políticas culturais. Tradução de Jamille Pinheiro. São Paulo: Elefante, 2019.

RIVERA Cusicanqui, Silvia. Ch'ixinakax utxiwa. Una reflexión sobre prácticas y discursos descolonizadores. Buenos Aires: Tinta Limón, 2010 (Pinturas)

CURIEL, Ochy. Construindo metodologias feministas desde o feminismo decolonial. Descolonizar o feminismo [recurso eletrônico]: VII Sernegra / Paula Balduino de Melo [et al.]., organizadora. - Brasília: Instituto Federal de Educação, Ciência e Tecnologia de Brasília, 2019, p. 32-51.

ALCOFF, Linda Martín. Uma epistemologia para a próxima revolução. Tradução: Cristina Patriota de Moura. Revista Sociedade e Estado, volume 31, número 1, Janeiro/Abril 2016. 
ESCRITURA, REPRESENTACIÓN Y COLONIALIDAD.

UNA HIPÓTESIS DE TRABAJO A PARTIR DE FANON

Alejandro De Oto

A fines de los años ochenta del siglo XX me encontraba cursando las últimas materias de una licenciatura en Historia, en la Universidad de la Patagonia San Juan Bosco, en Argentina. En una de esas materias, en concreto "sociología", uno de los textos centrales era "Los condenados de la tierra" de Frantz Fanon (1983). No tomé ese curso pero me presenté a rendir el examen final en calidad de libre, que en Argentina significa que uno puede no asistir a las clases pero si presentarse a dar un examen global que permite aprobar la asignatura. Recuerdo que leí por completo el libro de Frantz Fanon (1983), sobre el que me harían unas preguntas con seguridad, y recuerdo también que entendí poco y nada de lo que allí pasaba. A la distancia me parece extraño que fuera así porque en mis estudios había tenido contacto directo con los historiadores marxistas, en especial con aquellos que genéricamente designamos con la rúbrica de "marxismo inglés", lo cual haría suponer cierta familiaridad con la escritura de Frantz Fanon. Edward Palmer Thompson, Eric Hoy bsbawm, Ralph Samuel, Perry Anderson, y tantos otros, eran los nombres más frecuentados por entonces. No obstante, cuando leí "Los condenados de la tierra" me di cuenta que ese raro texto revolucionario hablaba de cosas diferentes y, sobre todo, tenía la impresión permanente de que hablaba de un tiempo ido, de un momento de la historia contemporánea que parecía sistemáticamente perdido tras los fracasos de las revoluciones del Tercer Mundo, de los movimientos de liberación nacional, de los horrores de las guerras emprendidas en términos de revoluciones, del despliegue sistemático de la configuración mental, política y cultural llamada neoliberalismo y un largo etcétera. Es decir, nada de lo que acontecía en mi contexto de referencias inmediato, la sociedad argentina de la postdictadura y de la débil transición democrática, junto con sus discursos afiliados a los consensos sociales, alentaba la lectura de semejante texto como una herramienta del presente. Por el contrario, si uno lo leía era para sentir cierta satisfacción por haber dejado de ser epígono de aquellos sueños perdidos en los pliegues generacionales de las dos décadas precedentes, los setenta y los sesenta. Ahora era nuestro derecho a la temporalidad el que estaba emergiendo y nadie, yo creo que tampoco, lo quería desaprovechar. Sin embargo, de todas las inconsistencias de mi lectura, que ahora me son reveladas por el hecho de haber transitado largamente la escritura de Frantz Fanon, la que más me impresiona, porque expresa el carácter de una práctica social fuertemente enraizada en los procesos de subjetivación de la sociedad argentina, fue el hecho concreto y brutal que nadie me hizo notar, una evidencia irrefutable acerca del autor de "Los condenados de la tierra": él era negro.

Tardé un tiempo relativamente largo en darme cuenta del error cognitivo o intelectual, en parte porque aquella primera lectura estuvo indicada para dar un examen, pero no habíallegado a mí por un interés genuino en los temasy problemas que trataba. Sin embargo, lo que me interesa de esta introducción sobre mi acercamiento inicial, luego abandonado, a la escritura de Frantz Fanon son dos dimensiones que se volvieron recurrentes en cada una de las inmersiones posteriores que hice en ella.

La primera, y principal, es que hay algo en mi error que es propio de un efecto y una consecuencia de la colonialidad del saber y de las geopolíticas del conocimiento $^{23}$; la segunda, tal vez menos clara y más difícil de delinear, se refiere a que se trata de un error que la escritura de Frantz Fanon relevará tanto para su narrativa como para las experiencias que intenta mostrar, al dar cuenta de los procesos que los cuerpos coloniales racializados atraviesan y conforman. Un error anclado en las regulaciones de una colonialidad del saber, pero al mismo tiempo desplegado en el modo de la tragedia de Sófocles, en tanto cada uno de los sucesivos descubrimientos que hacen los personajes fanonianos, lo hacen a partir del hecho de que sus equivocaciones y errores no son problemas morales sino centralmente cognitivos. Es decir, hay errores valorativos que hacen que las decisiones fueran incorrectas. Entonces, al advertirlos, la consecuencia es que nos empujan y conducen a zonas innominadas de la experiencia social e histórica que pueden producir (no es una determinación) una interpelación directa al mapa tranquilizador de conceptos y categorías de los saberes coloniales, entendiendo

$23 \quad$ Ambos conceptos tienen una dilatada presencia en las escrituras decoloniales. La colonialidad del saber, el igual que la del Ser (MALDONADO-TORRES, 2006, 2007) es una deriva del extensamente conocido concepto de Anibal Quijano: la colonialidad del poder (2007). Para un conjunto de intervenciones que fueron y son
centrales sobre el modo de concebir la colonialidad del saber, ver la compilación dirigida por Edgardo Lander centrales sobre el modo de concebir la colonialidad del saber, ver la compilación dirigida por Edgardo Lander
(1993), "La colonialidad del saber: eurocentrismo y ciencias sociales Perspectivas latino-americanas". Para el (1993), "La colonialidad del saber: eurocentrismo y ciencias sociales Perspectivas latino-americanas". Para el
concepto de geopolítica del conocimiento, sobre el que no discurro en este texto pero quiero dejarlo mencionaconcepto de geopolítica del conocimiento, sobre el que no discurro en este texto pero quiero dejarlo menciona-
do, hay varios trabajos de Walter Mignolo $(2001,2002,2003 a)$, que se pueden consultar y dan una visión precisa del problema en juego. 
por tal los conjuntos completos de disciplinas acuñadas en las matrices de la colonialidad y de la geopolítica del conocimiento.

Veamos esto con más detalle. Uso la colonialidad del saber como una categoría flexible, y en el sentido que permite describir situaciones en las que una de las dimensiones, o varias, vinculadas a las condiciones de producción del conocimiento están ausentes o, por el contrario, demasiado presentes. Quiero decir con ello que la colonialidad del saber como modo de reproducción de las lógicas coloniales implica una discriminación de factores centrales y secundarios en los procesos cognitivos. No sólo representa un modo de dejar de lado los conocimientos alter, en el sentido de conocimientos y saberes tramados en relaciones diferentes a las de la ciencia moderna, por ejemplo por sociedades no europeas ${ }^{24}$, sino que también funciona regulando los énfasis temáticos, conceptuales y los acentos dentro de los saberes normalizados bajo la rúbrica de científicos o académicos. De todos modos, me gustaría señalar que mi uso de la categoría pretende ocurrir en los límites de sus posibilidades heurísticas y sobre todo porque me ayuda a pensar la escena inicial de este relato. No creo que los traslados mecánicos funcionen pero si me parece, por el contrario, que si uno logra conectar una experiencia con la extensión semántica de un concepto o categoría gran parte de la rigidez y exterioridad desaparece ${ }^{25}$.

Ante todo, y para los efectos comparativos de los que siempre echamos mano en las ciencias humanas, la colonialidad del saber trabaja de manera muy parecida al discurso porque selecciona, recorta e indica que es adecuado o no pensar, en que es adecuado o no hacer preguntas de alguna relevancia para la relación entre los sujetos que conocen -sus vidas concretas en una articulación histórica precisa que implica producción de relaciones y poder- y aquello que es tendencialmente descrito como los objetos de investigación.

Su peculiaridad, sin embargo, es que ella se describe mejor por las omisiones que propone que por los elementos positivos. Por ejemplo, allí donde no hay reflexión sobre el lugar de enunciación, y no sólo en términos de coordenadas histórico-sociales,

$24 \quad$ Al respecto continúa siendo muy clara la intervención de Catherine Walsh (2007) en un texto que piensa directamente este problema y muestra un ejemplo de pensamiento alternativo. Me refiero a "Interculturalidad y 25 Fanon es un caso testigo de este tipo de proceso. Hay en su escritura una apuesta perr.

25 Fanon es un caso testigo de este tipo de proceso. Hay en su escritura una apuesta permanente por desplazar términos y conceptos de sus contextos originarios. Al respecto vale la pena revisar dos textos de Edward
Said $(1983,1999)$ donde se involucra a Fanon como una activo transformador, en nuevos contextos, de las conSaid $(1983,1999)$ donde se involucra a Fanon como una activo transformador, en nuevos contextos, de las conand The Critic" y "Travelling theories reconsidered". allí donde la materialidad de los cuerpos y sus articulaciones están ausentes o donde las tabulaciones sobre raza, género, sexo, clase ordenan subrepticiamente las encuestas, justo allí, estarían en marcha sus capacidades performativas. Tales capacidades actúan en diversos planos pero en donde se vuelve más incisiva y persistente la operación es donde los cuerpos aparecen separados de su materialidad concreta y son invocados por figuras conceptuales y categorías que los vuelven predecibles en sus trayectorias y relaciones.

Uso con total intencionalidad la idea de lo "adecuado" porque no es un tópico menor en la serie que estudia el vínculo entre cuerpos coloniales racializados, o simplemente cuerpos negros, y una normatividad (y racionalidad también) a la cual son atraídos y a la vez expulsados sistemáticamente, como de alguna manera ocurrió en mi lectura universitaria de "Los condenados de la tierra". La noción remite a un un vasto espacio reflexivo inaugurado por William Edward Burghardt DuBois (2003), en varios escritos, y sobre todo en "The Souls of the Black Folks". La idea de experimentar el propio cuerpo como algo inadecuado es una creación que conecta experiencia y concepto en este pensador y que tiene consecuencias. La más concreta es la percepción de cierto desdoblamiento frente a los discursos de la ciudadanía, de la civilidad, de lo civilizatorio de los sujetos interpelados por la evidencia de sus cuerpos. Un desdoblamiento que al mismo tiempo que promete algún tipo de ingreso a esas dimensiones lo hace estableciendo límites precisos. Lewis Gordon (2009) ha reflexionado sobre la inadecuación a partir del modo en que funciona la idea misma de teodicea. En ese marco, la normatividad del discurso blanco se ofrece como punto de referencia frente al cual la única posibilidad es la de que ocurran mayores o menores identificaciones con respecto a él. A partir de allí es una referencia infalible, como un dictum, en el mismo sentido que en la palabra de dios funciona frente a los creyentes. Ellos, sus intérpretes y los actos que lleven a cabo sólo pueden "adecuarse" a ese dictum pero si fallan no es culpa de la palabra sino de una inadecuación persistente, muchas veces originaria, de sus propias constituciones corporales. No es difícil reconocer, por otra parte, en este tipo de operaciones las discusiones de fondo sobre el problema de la razón subjetiva y objetiva que atraviesa gran parte de los debates filosóficos y a los cuales, por ejemplo, Max Horkheimer (1973) consagrara gran parte de su "Crítica de la razón instrumental". En particular esa imagen de la razón objetiva caracterizada por ser una suerte de fuerza contenida tanto en los hombres y mujeres como en las relaciones de clase, en las instituciones y la naturaleza que daba lugar, como consecuencia, a una racionalidad 
vinculada a los fines desplegada en términos objetivos en los sistemas filosóficos. El efecto para los individuos era justamente el de hacer que el grado de racionalidad se midiera a partir de la armonía o la capacidad de ajustarse a esa totalidad que la razón objetiva proponía como marco vinculado a los fines (HORKHEIMER, 1973, p.16). El punto sin embargo en el cual una razón subjetiva no podría pasar la prueba de ninguna de las formas esperables, sea como crítica de los fines, sea como elogio de los medios, es lo que William DuBois (2003) detecta con claridad: que los cuerpos racializados están por afuera de cualquiera de los parámetros que delinean esas racionalidades. En la saga de las ideas sobre la inadecuación que William DuBois (2003) despliega, Frantz Fanon aparece como una figura central sin mayores dificultades. Es en el capítulo cinco de "Piel negra, máscaras blancas", titulado "La experiencia vivida del negro" donde Frantz Fanon (2009) describe un conflicto con la demanda racionalista que la filosofía de Sartre ${ }^{26}$ le interpone a los cuerpos coloniales racializados que entregaron su causa, por decirlo de algún modo posible, a la afirmación radical de su singularidad. Frantz Fanon (2009) juega irónicamente con el arreglo a los fines de la dialéctica de la historia de Sartre, quien ve la crítica de las relaciones coloniales que lleva adelante la negritud como el movimiento antitético de la sociedad racista colonial. Y en el momento más alto, en el cual se articula prácticamente un sarcasmo sobre la operación ideológica de representar lo racional como fin ulterior, en este caso de una suerte de filosofía de la historia implícita en la dialéctica de Sartre, Frantz Fanon (2009) defiende cierto derecho a lo "irracional". Las consecuencias son devastadoras para una racionalidad objetiva que subyace a una filosofía de la historia. Por un lado porque hace evidente la operación que subsume toda singularidad en fines ulteriores. Por otro, porque revela que aun en el ejercicio de subsunción el cuerpo colonial sólo puede acceder a la racionalidad ulterior de los fines a costa de permanecer racializado. Porque la crítica de las condiciones que racializan lo expulsa de la posibilidad de la Historia y la Ciudadanía en tanto ellas se modelan en y con la misma racialización. En esa dirección lo tachado, prohibido, borrado del discurso no es centralmente el cuerpo colonial racializado sino la relación que racializa en el discurso y distribuye los objetos que designa, como dije antes, en arreglo a los fines.

No es demasiado difícil advertir las consecuencias epistemológicas de semejante asunto. Si algún sentido tiene para nosotros la afirmación radical e irónica

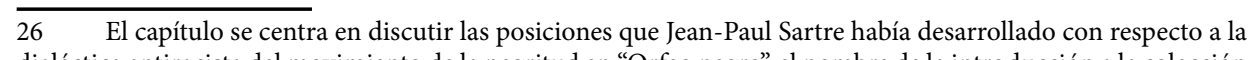
dialéctica antiracista del movimiento de la negritud en "Orfeo negro", el nombre de la introducción a la colección de poesía negra y malgache unos pocos años antes de la edición de "Piel negra, máscaras blancas". de una originalidad al estilo de las de Frantz Fanon, creo que es precisamente porque funciona como interrupción de una continuidad. Es decir, dispone sobre la mesa todos los elementos que configuran y modelan las figuras de la subjetividad en los cuerpos coloniales racializados y, al hacerlo, revela también que es en la performatividad donde están tanto la repetición de las razones ulteriores como su propia ruina. Tal tensión está relevada en su escritura. Frantz Fanon (2009) es persistente con la idea de que los cuerpos racializados en el col onialismo describen trayectorias abyectas casi en cualquier caso en que se los piense. Ahora bien, al decir "sin mayores dificultades", intento mostrar dos cosas al mismo tiempo. Por un lado que la evidencia sobre el problema de la racialización del colonialismo en Frantz Fanon (2009) es abrumadora, desborda su escritura. Por otro, que aún así, con esa evidencia en tiempo presente tan definida, incluso en el centro de su propia enunciación, ocurren lecturas, como aquella que me implica y con la que inicio este ensayo, que desplazan la evidencia hasta el punto de hacerla desaparecer.

Mi ignorancia en aquél examen podría admitir, es cierto, otras explicaciones mucho más simples, por ejemplo, que no había estudiado lo suficiente, sin embargo, nunca sentí que ese hubiera sido el caso. Por el contrario, el hecho de que Frantz Fanon fuera negro se me representó, una y otra vez, como una pregunta que no hubiera planteado y que, por cierto, nadie me hubiera alentado a hacer en aquél contexto. No porque mis profesores y profesoras fueran racistas, claramente no lo eran, sino porque creo que se interponía, al tiempo que se tramaba en mi subjetividad, un imaginario racial entre aquella escritura y mi lectura, que hoy asumo como parte de una de las performatividades más intensas de la colonialidad del saber, las que volvían a aquella pregunta fútil. Performatividades que, bien miradas, no hacían sino asegurar las diferencias entre cuerpo y mente, entre cuerpo y conocimiento a un punto tal que, por ejemplo, las relaciones entre colonizadores y colonizados - el gran tópico de "Los condenados de la tierra" - no parecían describir racializaciones coloniales sino posiciones en una escala creciente del proceso de "toma de conciencia". Es decir, una suerte de afirmación de la figura llamada "conciencia" frente a cualquier consideración sobre o del cuerpo.

Por otra parte, es difícil no quedar atrapado en las rigideces que presentan las categorías y los conceptos. Me debato en este texto si nombrar la colonialidad del saber implica o no una suerte de encierro de un problema complejo a favor de la síntesis. O si es un escape apresurado de la primera persona del singular con la que inicié este viaje. Uno puede hacer largos ejercicios exegéticos pero hay algo diferente que se vuelve palpable 
en las escrituras anticoloniales y ello es que del colonialismo, y de las colonialidades sobre todo, no se sale sino al precio de cierto baldío conceptual, de cierta experiencia de desapropiación no sólo de teorías, sino también de visiones del mundo, imaginarios, etc. Tal tensión, creo, es originante de un amplio repertorio de situaciones en las que coinciden otros movimientos realizados por fuera de los caminos anticoloniales. La crítica de la representación que puso en jaque al discurso filosófico durante largos períodos, pero también al estatuto de disciplinas fuertemente engarzadas en ese dispositivo ${ }^{27}$ cognitivo, como la antropología, la historiografía (con mayores dificultades debido, en gran parte, a la naturaleza de sus archivos ${ }^{28}$ ) es una fuente casi inagotable de escenas que se parecen a las que están en juego en la crítica anticolonial. La coincidencia, si se puede llamar de ese modo, se da en el mismo plano en el que la evidencia resulta abrumadora, es decir, en el mismo momento en que la saturación de un campo semántico, por ejemplo, o de una práctica ya no admite más que lo que Foucault $(1996$, p. 1) llamaba la "práctica milenaria de lo Mismo y lo Otro". Porque lo que está en juego es si, pensando en nuestros saberes, tal saturación no indica que una experiencia de desapropiación se puede convertir en un abandono disciplinario y si esa experiencia no es parte del proceso de una subjetividad en revisión, pongamos por caso, la propia. Si la respuesta es afirmativa el abanico de problemas escala de modo geométrico y permite una serie de consideraciones sobre las que quiero discurrir a continuación que involucran las biografías y los textos, las vidas y las escrituras.

Por estas rutas va la segunda dimensión que mencioné arriba, la de la tragedia, la del reconocimiento del error en tanto que error intelectual. En dos o tres oportunidades sostuve una tesis con respecto a la escritura de Frantz Fanon, tesis que excede las limitaciones iniciales que describen mis primeros movimientos en este ensayo, y que avanza sobre un conjunto más nutrido de sus textos y de las experiencias relatadas en los mismos. Esa tesis, si se puede presentar así, señala que gran parte de la relación escritura y conocimiento de la obra de Frantz Fanon se tramita en el registro de la tragedia, en su morfología. Es que, de alguna manera, la presentación de la subjetividad colonial, sea la del colonizado atravesado por los procesos de racialización tan visibles en "Piel negra, máscaras blancas", sea en los documentos recopilados en un texto relativamente reciente titulado "Écrits sur l'aliénation et la $27 \quad$ La noción de dispositivo aparece minuciosamente analizada por Giorgio Agamben (2011) en "¿Qué es un dispositivo?". Recorre las principales denivas del conce relaciones de poder y de saber, una de las caracteristicas que Agamben (2011, p.250) describe para el concepto $28 \quad$ Ver de Mario Rufer (2016), "El archivo: de la metáfora extractiva a la ruptura poscolonial". liberté" (FANON, 2015), o en los colonizados y colonizadores de "Los condenados de la tierra" (FANON, 1983), por citar los más conocidos, lo que uno percibe es que Frantz Fanon piensa en la trama de la tragedia cuando describe los itinerarios de los sujetos coloniales, lo cual implica, por otra parte, que es casi imposible deslindar su propia biografía de esa experiencia. Pero ante todo, lo que tiene de interesante el ejercicio es que se producen varios eventos al mismo tiempo al elegir esa implicación por la trama trágica. En primer lugar, el desmonte del mundo colonial reconoce dificultades en la escritura fanoniana que no son sólo las obvias, a saber, la derrota de la dominación económica y política de las metrópolis, o de tipo conceptual, me refiero al problema de cómo nombrar una experiencia descolonizadora, cómo enmarcarla, conducirla, cómo darle sentido crítico, etc. En segundo, porque hay elementos adicionales que tienen que ver con decisiones de orden narrativo, con el registro en el que se presenta el problema $y$, en ese plano, se pueden reconocer zonas que morfológicamente recuerdan a la tragedia y que parecen resolverse de una manera que llamaré "por saturación de la representación". Esta dimensión a mi juicio es crucial. Los textos de Frantz Fanon $(1983,2009,2015)$ están plenos de ejemplos que permiten caracterizar los modos en que ocurre lo que llamo el error intelectual o cognitivo, que no sería sino una forma concreta de la performatividad de la colonialidad del saber, aún cuando el autor no hablara con ese vocabulario. Tanto los personajes de sus relatos, Jean Veneuse, el joven negro de la colonia que estudia en la metrópoli y ensaya por todos los medios su proceso de acercamiento al núcleo de la cultura metropolitana blanca, sea en las costumbres, en la lengua o el deseo, Nini, la maltratada personaje de la novela de Mayotte Capécia, o el propio Frantz Fanon (2009) discurriendo en el capítulo cinco de "Piel negra, máscaras blancas" contra la demanda, como vimos antes, de la dialéctica de la historia de Sartre, o describiendo los modos en que los esquemas corporales de Merleau-Ponty no funcionan en la experiencia vivida de los sujetos racializados (FANON, 2009), o en la ausencia de una ontología para los negros colonizados, en cada una de esas tramas se presenta el problema de habitar un universo de significados y de sentido que parece, por todos los medios, desmentir la posición de los cuerpos coloniales con respecto a ellos. Frantz Fanon comprende muy rápido que habitar el error intelectual que supone no reconocer las "coordenadas febriles" del mundo implica que algo funciona en exceso con respecto a los personajes, sean los conceptuales, los anecdóticos o literarios. La figura del lenguaje, evocado en "Piel 
negra, máscaras blancas" a partir de la imagen de Valery, como "el dios extraviado en la carne" es crucial para describir esta complejidad en la que se imbrican en situación colonial, casi imperceptiblemente, varias de las figuras de la tragedia, a saber, la peripecia, la anagnórisis y la catástrofe (FANON, 2009, p. 50). Él es enfático cuando piensa en el idioma francés al señalar que "hablar es emplear determinada sintaxis, poseer la morfología de tal o cual idioma, pero es, sobre todo, asumir una cultura, soportar el peso de una civilización" (FANON, 2009, p. 49). Queda claro, eso pienso, que tal peso no se refiere solamente a las dimensiones semánticas, gramaticales y sintácticas del idioma, sino que refiere a la pregunta persistente e inquietante que late en toda su escritura de si es posible decir el mundo de otro modo y de si ese otro modo tiene alguna chance de re-conectar los cuerpos entre sí.

Si por un lado, el de la peripecia, cada uno de los eventos o procesos narrados por Fanon (2009) son objeto de cambios repentinos, por otro, ocurre en la estructura de sus relatos cierto reconocimiento de los límites de la inteligibilidad del mundo colonial. Se hace presente la evidencia, por fuerza de una anagnórisis, me gustaría decirlo de ese modo, de los límites de lo inteligible en los términos de esas trayectorias vitales, de una suerte de reconocimiento que funciona de manera compleja porque revela el error pero no asegura el resultado en términos de conciencia con respecto a él. Y si sostenemos la figura de la catástrofe ella opera en un sentido doble en la escritura fanoniana: el mundo colonial aparece como una ruina en sí misma para los sujetos y, a la vez, todo descenso a los infiernos ocurre en la saturación y en el desmonte de las coordenadas que ordenan ese mundo, que no son sino las coordenadas de la representación. Uno podría decir en este punto, con algún sentido moral de justicia, que si cesa el colonialismo no hay razón para la catástrofe, a menos claro, que entienda que las figuras de la subjetividad creadas allí son las que atraviesan el proceso de su disgregación, son las que experimentan el drama de la representación cuando todo el universo disponible para pensarse habita dentro de ella.

En este momento del texto quisiera proponer algunas preguntas que atañen, eso creo, a lo que he venido exponiendo hasta el momento. Una de ellas me sigue pareciendo pertinente, incluso por todos los medios en los que sela ensaya, y es la pregunta que evoca el problema acerca de cómo se enuncia. De manera deliberada propongo desplazar por un instante el problema del lugar de enunciación porque creo que el "cómo" desempeña un papel más importante que el locus, incluso cuando comparto lo que está en juego en esa idea. No desconozco, preciso decirlo, la importancia que el concepto de lugar de enunciación tiene en lo que respecta a las constituciones discursivas desde donde se enuncia, en especial cuando se trata de hacer emerger otros locus de enunciación en términos epistemológicos. El concepto es fuertemente articulador de una saga crucial de textos de un autor como Walter Mignolo (2003b).

Me interesa, sin embargo, trazar algunas observaciones finales en relación a cómo se enuncia cuando están en juego encrucijadas como las que los textos de Frantz Fanon proporcionan, las cuales, antes bien que constituir una suerte de positividad, en el sentido de afirmar cómo debería ser el mundo, se tramitan en situaciones auto-contradictorias $y$ en otros casos como afirmaciones que funcionan en tanto que interrupciones de la performatividad del discurso epistemológico que racializa. Quiero pensarlas, así mismo, en relación a mi "error" intelectual inicial que pone en primer plano, por muchos caminos, la trama de una colonialidad en mi propia experiencia intelectual.

Ahora bien, ello implica considerar algunos problemas comunes cuando se debaten estas cuestiones. El primero de ellos es cómo proceder a partir del "error". Una respuesta es la que deposita toda la confianza en la respuesta que "descubre" y "reconoce" como ausente una dimensión aparentemente central y, al hacerlo, restituye una parte del tejido perdida u ocultada. En concreto, se trata de mostrar lo ausente a partir de la operación que racializa la escritura de Frantz Fanon, desplazando el hecho de que era negro, al hacerla circular como una intervención en el espacio de las teoría críticas del siglo XX. Allí vale detenerse y preguntar si se restituye algún problema o, por el contrario, si eso va a depender del modo en que es presentado tal problema. Por ejemplo, ¿Qué ocurre si la crítica devuelve la condición negra de Frantz Fanon a su escritura? ¿Cómo son los deslizamientos sutiles en la relación entre biografía y escritura? ¿De qué manera se implican entre sí, qué ocurre cuando la subjetividad y la experiencia se traman directamente con los modos expresivos de una escritura y con los temas, categorías y conceptos que en ella se forjan? ¿Cuál es la serie de exclusiones que en contraste actúan si la racialización aparece o no en escena, no sólo del lado de la experiencia sino en el fundamento mismo de la crítica, pero ya no como exterioridad, dado que nunca lo fue, sino como condición indispensable para entender el tipo de conocimiento en juego? Cada una de estas notas/preguntas a mi juicio indica de partida que no hay soluciones simples a la vista. Quiero decir que por un lado no sería posible asumir una respuesta moral del tipo "sólo quienes 
experimentan estos procesos pueden hablar de ellos en términos de conocimiento" o "dado que la experiencia humana es común, independientemente de las situaciones, hay un núcleo comunicable de ideas y experiencias". Ambas respuestas conducen a un callejón sin salida, sea por la vía de un exclusivismo, del que se han escrito bibliotecas, sea por la vía de un humanismo que respeta lo diverso desplazando la diferencia. En principio porque acepta en uno y otro caso el hecho de cierta ontologización que refuerza las posiciones pero las vuelve excluyentes y expulsivas del problema del poder y de la diferencia cuando se los piensa históricamente. Al mismo tiempo, convierte los discursos críticos, como el de Frantz Fanon, por ejemplo, en una suerte de fenómeno autocontenido que sólo se lo puede entender o explicar por su pertenencia a la filiación raza y colonialismo o a una humanidad compartida en la diversidad.

Creo que la configuración trágica de la escritura fanoniana, al menos en sus dos textos más conocidos, "Los condenados de la tierra" y "Piel negra, máscaras blancas", da algunas pistas para pensar los problemas que intento relevar con las preguntas anteriores. En primer lugar esa configuración además de poner en juego las dimensiones formales de las que brevemente hablé, permite mantener la zona afirmativa de conceptos, categorías y experiencias en un lugar relativamente inestable porque nunca se está en control de todas las variables históricas. Frantz Fanon pone en primer plano el problema de que las fuerzas y performatividades que el régimen colonial desata sobre los cuerpos y las vidas acechan en cada término destinado a conjurarlas. Al hacer eso, en un mismo movimiento quedan expuestos los límites representacionales de discursos pretendidamente universales, aun aquellos más difíciles de detectar en esa función, como gran parte de los discursos filosóficos que le son contemporáneos, el existencialismo, la fenomenología, el materialismo histórico, por nombrar los más evidentes. A su vez quedan expuestos los límites de una enunciación que ahora restituye la encrucijada racializada y subalterna de la que intenta emerger. El siguiente paso, entonces, no se da en ninguna dirección parecida a las acostumbradas. Al mismo tiempo que se puede describir la trayectoria de una consciencia emergente, porque son escrituras emancipatorias, lo más potente ocurre en el momento en que límites mencionados quedan advertidos. No se trata de una zona despejada de incertidumbres para que la conciencia actúe, sino una suerte de aceleración o frenesí que consume todo el combustible representacional del mundo colonial. Lo pienso como la saturación de un campo semántico en el que se despliega el proceso repetitivo de la representación hasta el punto en el que pierde todo anclaje, digamos, se pierde la capacidad de articularse en el signo. Frantz Fanon conecta ese proceso con los cuerpos coloniales de manera tal que ellos repiten sistemáticamente los movimientos en los cuales la representación los concibe pero al mismo tiempo en la misma repetición la saturan. Asílas imágenes que genera en su escritura son portentosas, ellas van desde el vaivén de las palmeras azotadas por el viento que prefiguran el ir y venir de las mercancías en los puertos coloniales (FANON, 1983) pasando por la secuencia de los esquemas corporales y los movimientos imposibles de naturalizar, primero por los cuerpos en el colonialismo debido a los relatos racializados que los describen y luego por el hecho absoluto de una piel para la que no hay sino inadecuación (FANON, 2009), hasta la tensión permanente del colonizado siempre acechado y al acecho dentro los límites estrechos en que la vida se produce en el cuerpo colonial (FANON, 1983).

No cabe duda que se puede debatir largamente si hay alguna salida de la representación como dispositivo cognitivo acuñado en las tramas de la colonialidad del saber pero como es obvio no es algo que pueda resolver aquí. Por el contrario, mi hipótesis es de menor trascendencia. Ella propone que al hacer énfasis en cómo se enuncia, lo que se destaca es el efecto de saturación de la representación como una característica de la escritura anticolonial fanoniana. El problema entonces no radica sólo en pensar cuales otras epistemologías han sido reprimidas en el proceso de la colonialidad del saber (algo fuera de discusión), sino también en entender por qué medios y de qué manera proceden en sus actos performativos escrituras afiliadas a los cuerpos que disputan la colonialidad. Mi respuesta provisoria habita entre los problemas abiertos por mi desconocimiento inicial, como una de las tantas tramas de una colonialidad del saber, y la performance de una enunciación que siempre encuentra posibles emergencias en el contexto de una subjetividad tramada en el colonialismo. Allí, tal vez, el baldío sea una posibilidad.

\section{Referencias}

AGAMBEN, Giorgio. ¿Qué es un dispositivo?. Sociológica, México, año 26, n. 73, p. 249-264, may./ ago. 2011.

DUBOIS, William Edward Burghardt. The Souls of Black Folk. En: BAYM, Nina (Ed.). The Norton Anthology of American Literature. Nueva York: W.W. Norton, 2003. p. 1702-1718.

FANON, Frantz. Los condenados de la tierra. México: FCE, 1983.

FANON, Frantz. Écrits sur l aliénation et la liberté. Textos reunidos y presentados por Jean Khalfa y Robert Young. París: La Découverte, 2015.

FANON, Frantz. Piel negra, máscaras blancas. Traduccion A. Useros Martin. Madri: Akal. 2009. 
FOUCAULT, Michel. Las palabras y las cosas. Una arqueología de las ciencias humanas. Traduccion E. C. Frost. México: Siglo XXI, 1996.

FOUCAULT, Michel. La arqueología del saber. Traduccion A. Garzón del Camino. México: Siglo XXI, 1985.

GORDON, Lewis. Decadencia disciplinaria. Pensamiento vivo en tiempos difíciles. Quito: Abya Yala, 2013.

GORDON, Lewis. Fanon y el desarrollo. Una mirada filosófica Traduccion A. De Oto. En: MIGNOLO, Walter. La teoría política en la encrucijada decolonial. Buenos Aires: Ediciones del Signo, 2009. p. 125-162.

HORKHEIMER, Max. Crítica de la razón instrumental. Traduccion H. Murena y D Vogelmann. Buenos Aires: Editorial Sur, 1973.

LANDER, Edgardo. (Comp.). La colonialidad del saber: eurocentrismo y ciencias sociales Perspectivas latino-americanas. Buenos Aires: CLACSO, 1993.

MALDONADO-TORRES, Nelson. La topología del ser y la geopolítica del saber. Modernidad, imperio, colonialidad. En: SCHIWY, Freya; MALDONADO-TORRES, Nelson; MIGNOLO, Walter. (Des)colonialidad del ser y del saber. Cuaderno 1. Buenos Aires: Ediciones del Signo, 2006. p. 63-130.

MALDONADO-TORRES, Nelson. Sobre la colonialidad del ser: contribuciones al desarrollo de un concepto. En: CASTRO-GÓMEZ, S; GROSFOGUEL, R (Eds.). El giro decolonial. Reflexiones para una diversidad epistémica más allá del capitalismo global. Bogotá, Siglo del Hombre Editores, 2007. p. 127-168.

MIGNOLO, Walter. Capitalismo y geopolítica del conocimiento. Buenos Aires, Ediciones del Signo, 2001.

MIGNOLO, Walter. Los estudios culturales: geopolítica del conocimiento y exigencias/necesidades institucionales. Revista iberoamericana, v.69, n. 203, p. 401-415, 2003a.

MIGNOLO, Walter. Historias locales; diseños globales: colonialidad, conocimientos subalternos y pensamiento fronterizo. Madrid: Akal, 2003b.

MIGNOLO, Walter. The Geopolitics of Knowledge and the Colonial Difference. The South Atlantic Quarterly, v. 101, n. 1, p. 57-96, dic. 2002.

QUIJANO, Aníbal. Colonialidad el Poder y Clasificación Social. En: CASTRO-GÓMEZ, S; GROSFOGUEL, R. (Eds.). El Giro Decolonial: Reflexiones para una diversidad epistémica más allá del capitalismo global. Bogotá, Siglo del Hombre Editores, 2007. p. 93-126.

RUFER, Mario. El archivo: de la metáfora extractiva a la ruptura poscolonial. México: Siglo XXI, 2016.

SAID, Edward. The world, the text, and the critic. Cambridge, Estados Unidos: Harvard University Press, 1983.

SAID, Edward. Travelling theory reconsidered. En: GIBSON, Nigel (Ed.). Rethinking Fanon. The continuing dialogue. Nueva York: Humanities Books, 1999. p. 197-214.

WALSH, Catherine. Interculturalidad y colonialidad del poder. Pensamiento y posicionamiento "otro" desde la diferencia colonial. En: CASTRO-GÓMEZ, S.; GROSFOGUEL, R. (Eds.). El Giro Decolonial: Reflexiones para una diversidad epistémica más allá del capitalismo global. Bogotá, Siglo del Hombre Editores, 2007. p. 47-62.
Alcione Correa Alves

Tituba speaks

The magic I brought wrapped up tight in the bosom of my chest to Salem, Massachusetts,

Came not from slaves, nor from my Guyanese Indian people, but from a white woman

Who taught it to me back in Barbadoes where I forcefully taken. She the one, those days we alone

On the plantation, showed me how to curse someone and how to turn-back-the-curse to cure someone.

Some nights that woman and I would look up at the flat white face of the moon -

And it is true, we both called the moon mother. She had a black cat about her

She called familiar. There was a broom she never touched leaning against the far wall in the corner (BISHOP, 2016, p. 257)

Para fins didáticos, ao longo das discussões ora propostas, este texto vislumbra a representação enquanto jogo com vistas a, a partir deste exercício, tratar o problema da representação no tocante a dois temas específicos de investigação: um corpus de literaturas negras americanas ou, mais precisamente, de literaturas enunciando desde um lugar negro americano; e um conjunto de referenciais teóricos que enunciam desde um lugar negro.

Nesta perspectiva particular de produção e difusão de conhecimento, por nós investigada mediante os princípios de um modelo acadêmico estabelecido (a saber, sob as regras do campo dos Estudos Literários, no Brasil), aceitar-se-ia, como associação válida ao nome de Tituba constante no título do poema de Jacqueline Bishop, a recordação de uma exposição ocorrida este ano, no Musée d’Orsay, intitulada "Le Modèle noir. De Géricault à Matisse”. De modo mais específico, como parte desta exposição, há um quadro a evocar interesse direto, originalmente intitulado "Portrait d'une négresse", assinado por Marie-Guillemine Benoist no ano de 1800. 


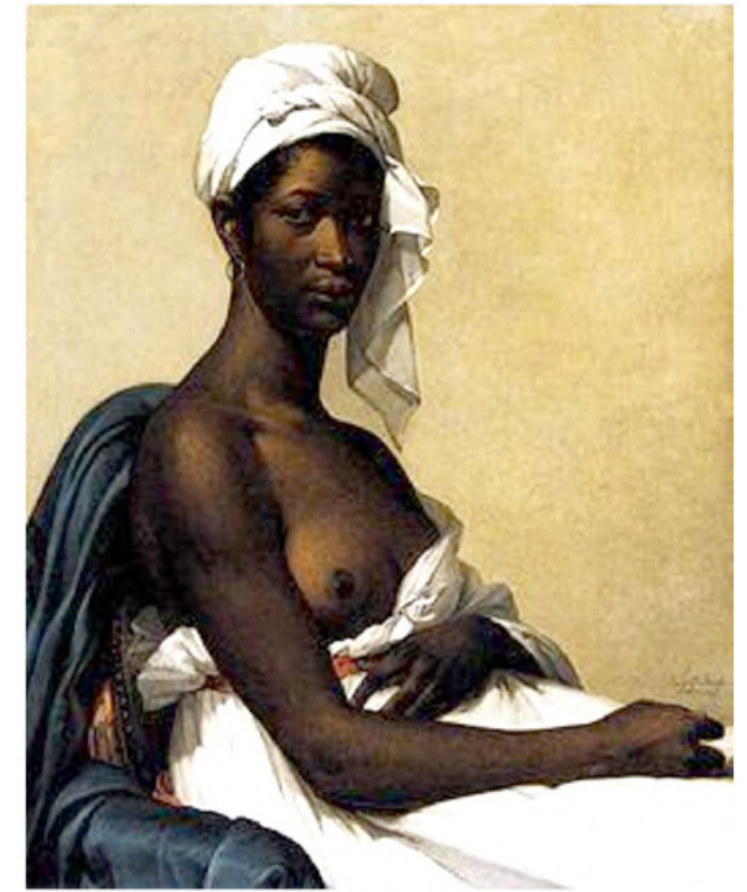

BENOIST, Marie-Guillemine. Portrait d’une négresse (1800). Musée du Louvre, Département des peintures. Disponível em: <https://fr.wikipedia.org/wiki/Portrait_d\%27une_n\%C3\%A9gresse\#Titre_du_tableau >.

Sublinhe-se, como dado fundamental à exposição no Musée d'Orsay, seu esforço em observar a representação de sujeitas(os) negras(os) desde um cânone da pintura ocidental, sobretudo em quadros alusivos ao período de escravização nas colônias francesas nas Américas. $O$ quadro de Benoist fora pintado imediatamente após a [primeira] abolição da escravização nas colônias francesas ${ }^{29}$; e imediatamente antes do desfecho da Revolução Haitiana (1791-1804) ${ }^{30}$. Acerca do quadro, observemos seu percurso de renomeação: de "Portrait d’une négresse", doravante se encontra em exposição permanente no Musée du Louvre, denominado "Portrait d'une femme noire", com subtítulo "Salon de 1800, sous le titre Portrait d'une négresse"; e, com o advento da exposição inicialmente referida neste texto,

$29 \quad$ E imediatamente anterior ao restabelecimento da escravizacão de populações negras americanas nas colônias francesas, por Napoleão I, com posterior abolição no ano de 1848 .

Despeito da contemporaneidade (cronológica), as pinturas de Jean-Baptiste Debret, ambientadas no contexto escravagista brasileiro, proporcionam interpretacões essencialmente distintas daquelas, para os fins deste trabalho, propostas ao quadro de Benoist: no Brasil, cujos processos abolicionistas culminarão apenas em 1888 (quase um século após o contexto do quadro de Benoist), os quadros de debret operam em um registro de (nossa hipótese) naturalização das relações escravagistas e suas consequências políticas. passa a ser denominado "Portrait de Madeleine". Desde um lugar de enunciação negro, se observa o nome enquanto prerrogativa eminentemente humana ou, em outros termos: a obliteração do nome enquanto gesto de desumanização; e, em um gesto posterior, a restituição do nome como agência ante a desumanização inicial. Disto tratara a exposição em questão, no Musée d'Orsay: em visita a um cânone centroeuropeu das artes visuais, observar a obliteração dos nomes de sujeitas(os) negras(os) que, em sua condição de modelos, frequentemente têm sido vistos como objetos (como matéria-prima) à produção artística centroeuropeia. Propõe-se que a hipótese da restituição do nome, como primeiro movimento ante a desumanização de sujeitas(os) negras(os), visa à formulação de um problema acerca da violência epistêmica imputada: para além do sequestro, da escravização nas monoculturas em solo americano, se seguira a desumanização de sujeitas(os) negras(os) enquanto gesto necessário, em tais termos. $\mathrm{O}$ adjetivo négresse opera a este fim, exacerbando a desumanização já presente em seu antecessor nègre, pejorativo em língua francesa, sem a condição de operar como sinônimo de noir (e $)^{31}$ : neste sentido, o deslizamento de sentidos na primeira renomeação, "Portrait d'une femme noire", oferece um primeiro posicionamento à violência epistêmica contra Madeleine (enquanto mulher escravizada, propriedade da família de Benoist), ainda que insuficiente por sustentar a desumanização, lhe negando a prerrogativa do nome.

"Portrait d'une négresse", hoje "Portrait de Madeleine", esteve ao centro de dois movimentos contemporâneos que, desde um lugar de enunciação negro, discutem a agência de sujeitas(os) negras(os) ante a violência epistêmica: o segundo, neste ano, por conta da exposição no Musée d'Orsay; e o primeiro, no ano passado, com o advento do clipe à canção "Apeshit", no qual Beyoncé e Jay-Z percorrem o acervo do Louvre, em uma letra a discutir [o acúmulo do que reconhecemos como] patrimônio cultural ocidental e [o peso do] colonialismo, a partir das obras com as quais interagem. E, nesta escolha, "Portrait d'une négresse" ocupa sua centralidade.

Ce qui me stupéfait et me révoltait, ce nétait pas tant les propos qu’elles tenaient, que leur manière de faire. On aurait dit que je nétais pas là, debout, au seuil de la pièce. Elles parlaient de moi, mais en même temps, elles m’ignoraient. Elles me rayaient de la carte des humains. J’étais un

31 A este respeito, vide a peça de Jean Genet, Les nègres (em que sua tradução ao inglês sustenta o problema da violência epistêmica ao centro, traduzindo seu título a The niggers); ou o subtítulo da peça de Aimé Césaire, Une tempête: "adaptation pour un théâtre nègre". 
non-être. Un invisible. Plus invisible que les invisibles, car eux au moins détiennent un pouvoir que chacun redoute. (CONDÉ, 2008, p. 44)

A desumanização de Tituba, compreendida desde sua agência ao centro do discurso, ao centro da voz narrativa, oferece uma chave de leitura a Moi, Tituba sorcière..., romance de Maryse Condé: mediante o recurso a uma definição precisa de humanidade (nos termos do excerto: de ser, metafísico), Tituba assinala o gesto de desumanização de seus escravizadores, assim como da população de Salém como um todo quando, para além de um silenciamento (elles m’ignoraient), se soma a violência da negação de um estatuto de humanidade (elles me rayaient de la carte des humains. Jétais un non-être). E, importante aos fins deste texto, do ponto de vista de uma descolonização de nossos saberes: antes de reconhecer a si própria como não-ser, Tituba assim se reconhece quando examinada desde um epistema centroeuropeu, colonial, no contexto de Salém. Deste exercício de compreender este epistema, Tituba avança à agência sobre o nome ou, precisamente, sobre a redução de seu Diverso a um ofício, o de feiticeira, por parte dos habitantes de Salém.

Nessa passagem, Tituba expressa sua revolta em relação à maneira como as mulheres brancas falavam dela, explicitando que, embora elas estivessem no mesmo cômodo, a personagem-título era ignorada, riscada do mapa dos humanos: "J'était un non-être. Un invisible". Nesse sentido, observa-se que, na obra de Maryse Condé, Tituba se esforça para elaborar um discurso que conteste e deslegitime a invisibilidade atribuída aos sujeitos negros em subalternidade, assim como a obliteração dos discursos desses sujeitos negros (LEAL, 2017, p. 29-30)

Assim propomos a presente interpretação de Tituba, seja em Condé, seja em Bishop: a voz narrativa, neste movimento de compreender seu devir negro, inserida - e violentada - por um epistema centroeuropeu. Se, retomando o mote inicial, pensamos a representação como um jogo, proporíamos, como hipótese a ser examinada ao longo do texto, a agência de sujeitas(os) negras(os) como movimento no tabuleiro, seja por parte da nomeação de Madeleine, seja no exame do acervo do Louvre por Beyoncé e Jay-Z. Compreendendo cada movimento de jogo como agência (em vez do recurso ao operador resistência, como conceito circulante na comunidade científica ao investigar construções identitárias negras), espera-se, ao longo das discussões neste texto, compreender a violência epistêmica ao centro dos gestos de desumanização de sujeitas(os) negras(os) quando representadas(os) de modo exógeno ${ }^{32}$. Para além de uma noção de resistência a necessitar de nossos Outros o contramovimento, o gesto reativo, a resposta a evitar o xeque, como hipótese de trabalho examinar-se-á, de modo elementar, a agência de sujeitas(os) negras(os) enunciando desde um lugar negro americano, em movimentos compreendidos de modo isonômico em um mesmo tabuleiro: como o procederam Beyoncé e Jay-Z produzindo sentidos no Musée du Louvre; como o procederam o poema de Jacqueline Bishop e o romance de Maryse Condé, produzindo sentidos ao discurso de Tituba desde si mesma e sua produção de conhecimento. Uma vez mais, a representação enquanto jogo, supondo a possibilidade de isonomia ante o tabuleiro, as peças e seus movimentos; supondo um estatuto de humanidade e suas prerrogativas específicas a ambas(os) jogadoras(es), sem que a uma( ) caiba uma posição natural[izada] de resistir às estratégias da(o) oponente.

Pois, por algum argumento (ainda a compreender seu funcionamento), uma vez que nos servimos da categoria de resistência a definir a natureza daqueles que denominamos nossos Outros (em uma palavra: a quens situamos no campo da diferença), estamos a abrir mão da isonomia das regras do jogo: como se, para fins de cálculo, sujeitas(os) não-brancas(os) jogassem sempre, necessariamente, com as pretas.

Não-brancas(os) jogam necessariamente com as pretas

Lo que estoy intentado denunciar aquí es que si efectivamente existe una colonización discursiva de las mujeres del tercer mundo y sus luchas, eso no sólo ha sido una tarea de los feminismos hegemónicos del Norte sino que estos han contado indefectiblemente con la complicidad y el compromiso de los feminismos hegemónicos del Sur, dado sus propios intereses de clase, raza, sexualidad y género normativos, legitimación social y estatus quo (MIÑOSO, 2014, p. 319)

32 Eis o mote do ensaio Cultura e imperialismo (SAID, 1995): examinar as representações de sujeitos em-subaternidade, habitantes de colônias inglesas e francesas no século XIX, a partir das fissuras dos textos literários canônicos de Inglaterra e de França, publicados neste mesmo período. Como bibliografia central ao problema da representação de sujeitas(os) negras(os) em tais termos, indica-se o capi
desejo e resistência", em Olhares negros: raça e representação (hooks, 2019, p. 64-95). 
Naquilo que Yuderkys Espinosa Miñoso demarca como la complicidad y el compromiso de los feminismos hegemónicos del Sur, repousaria uma naturalização de nosso lugar a partir de uma ideia de suficiência do Sul geográfico: dele, decorreria nossa pretensão teórica a um Sul político; dele, decorreria o caráter contrahegemônico seja de nossa teoria, seja dos resultados e discussões da ciência que propomos. A observada complicidad y el compromiso de los feminismos hegemónicos del Sur se mostra em diálogo à noção de Ocidente exposta por Glissant (1997) na primeira nota de rodapé de Le discours antillais: "L'Occident nest pas un lieu. L'Occident est un projet". De nossa posição em um Sul geográfico, não decorre nosso Sul político, o qual nos solicita uma construção contínua ou, em outros termos, um gesto de descolonização contínua do conhecimento científico produzido e difundido, uma vez que investigamos sujeitas(os) negras(os) frequentemente a situar seus devires negros desde um Sul epistemológico (ou, nos termos de Glissant: desde fora do Ocidente).

Una buena parte de las feministas de la periferia, gracias a sus privilegios de clase y raza, si bien en desventaja en relación a sus compañeras del Norte, en sus propios países se han beneficiado de los marcos conceptuales occidentales y etnocéntricos que producen -como su otro constitutivo - a la «mujer (negra, india, pobre, lesbiana, ignorante) del tercer mundo». Ellas participan activamente en el proyecto que hace imposible la agencia y la escucha de la subalterna latinoamericana (MIÑOSO, 2014, p. 319-320)

No melhor dos cenários possíveis, enfrentaríamos um problema epistêmico a obstar nossa compreensão destas(es) sujeitas(os) caso os submetêssemos a um quadro teórico ocidental; no pior deles, proporíamos uma ciência que, ao fim e ao cabo, necessitaria da manutenção da violência epistêmica como sua condição sine qua non. Para nos justificar, para existir enquanto campo do conhecimento dedicado à investigação de sujeitas(os) em-subalternidade, necessitaríamos de sua permanência em uma condição de subalternidade, de modo a hace[r] imposible la agencia y la escucha de la subalterna latinoamericana. Em coerência a nossos fundamentos, cabe desnaturalizar nosso próprio lugar, deixando de tomar nosso lugar-Sul como premissa. Esta é a crítica de Spivak ao pós-estruturalismo francês, assim como a de Miñoso a Spivak e Mohanty. Se não o fazemos, não apenas contradizemos nossa adesão a Spivak como contribuimos decisivamente, em nosso trabalho científico, para "hace[r] imposible la agencia y la escucha de la subalterna latinoamericana”.

Los feminismos pos y decoloniales, el black feminism, los feminismos de color y tercermundistas marcan una tercera forma de disidencia con respecto al feminismo blanco hegemónico, relacionada con la visibilización de los posicionamientos geo y corpopolíticos de las mujeres, cuestión que reabre y radicaliza la crítica a un sujeto universal femenino, que hemos discutido con anterioridad. Para las teóricas feministas que se posicionan dentro de estas trayectorias, la discusión del feminismo blanco habría dado prevalencia a los análisis de género, soslayando otra gran cantidad de marcas identitarias desde las que se ha definido a las mujeres. Este gesto borraría las posibilidades de un análisis de las condiciones históricas que le dieron origen a una organización social que sostiene estructuras jerárquicas de opresión que no son explicables a partir del género exclusivamente (Espinosa-Miñoso, 2014) (CABRERA; VARGAS MONROY, 2014, p. 30)

Isso talvez nos levasse à imagem anterior, de sujeitas(os) negras(os) obrigadas(os) a jogar sempre com as pretas, [nos casos em que sua resistência lograsse êxito ao ponto de lhes facultar a prerrogativa do jogo] (ALVES, 2015), como condição a sua participação naquilo que Bhabha denominara equação conhecimento-poder (BHABHA, 1998, p. 45). Parte de nossas investigações, no atual andamento do campo, adotam a categoria da resistência como premissa às literaturas negras [contemporâneas], independente de seu lugar de enunciação ${ }^{33}$. Uma das facetas deste risco, apontado por Miñoso, de que nossas críticas "se asientan sobre las mismas bases que las operaciones de dominio" de tal modo a corroborar "la reafirmación de una diferencia específica (naturalizada) de los grupos subordinados en relación al sujeto hegemónico”, mostrar-se-ia quando naturalizamos não apenas os sujeitos como, também, seus discursos que buscamos compreender. Já sabemos, de antemão e desde sempre, a dinâmica de nosso objeto, assim como as conclusões às quais chegaremos em nossas interpretações porque, uma vez naturalizadas(os) - ao que entra em cena nossa posição como Sujeito, conforme a crítica de Spivak - podem responder só e somente só de uma maneira específica, equivalente àquela interpretada em nossa ciência, frequentemente 33 Donde se concluiria, do ponto de vista metodológico, que nós investigadoras(es) já saberíamos, de antemão e desde sempre, seja a dinâmica de nosso objeto (sujeitas(os) negras(os) como aquelas(es) que resistem), temão e desde sempre, seja a dinâmica de nosso objeto (sujeitas(os) negras (os) como aquelas (esc
seja as conclusões às quais chegaremos em nossas interpretaços dos sujeitos e seus discursos. 
soslayando otra gran cantidad de marcas identitarias desde las que se ha definido a las mujeres. Destarte, decorreria que, quando operamos cientificamente "la reafirmación de una diferencia específica (naturalizada) de los grupos subordinados en relación al sujeto hegemónico", a naturalização que promovemos não apenas circunscreveria o lugar possível aos sujeitos [a sua revelia] como lhes sonegaria, no interior de nossa ciência, a legitimidade ao discurso. Só é possível o discurso desde um lugar de cultura, jamais desde um lugar de natureza.

Nesta definição exógena do nome e das produções de sentido dele decorrentes, encontramos um diálogo com as duas dimensões caras ao par Negro/raça, tal como preconizadas por Achille Mbembe em Crítica da razão negra (2014): ao Negro não lhe cabe a definição de si, do que seja o ser negro; tampouco lhe cabe a taxonomia de quem seja negro. $\mathrm{O}$ estatuto do ser e da diferença, em sua condição de categorias ocidentais conduzidas à universalidade, consistem em definições tributárias desta universalidade, na qual o sujeito ocidental, centroeuropeu, define a seus Outros, define a diferença. Uma vez aceitos tais termos, até que ponto não relegamos a [os que tomamos como] nossos Outros, como definição [exógena] de sua natureza, características eminentemente físicas visto que a complexidade se mostra uma prerrogativa do Sujeito? Até que ponto não corremos o risco de tomar, como define bell hooks (2019, p. 64-95), nossos Outros como commodities do Sujeito ${ }^{34}$ Ademais, a pressuposição destes comportamentos, tidos como naturais, se atualiza nas violências contra estas(es) sujeitas(os), a cada ocasião em que eventualmente não correspondam ao que, natural[izada]mente, se espera deles. Caso atinjam o direito ao jogo, sujeitas(os) não-brancas(os) jogariam, natural[izada] mente, com as pretas, sem que lhes coubesse a compreensão das regras de distribuição das peças, tampouco a compreensão de quem lhes determina não-brancas(os).

Picasso, I want my face back

the unbroken photography of it

Once I lived to be stroked

by the fingers of your brushes

$34 \quad$ Na introdução a Olhares negros, Rosane Borges apresenta a ideia de commodities, desenvolvida por bell hooks no capítulo 2: "O segundo capítulo - "Comendo o Outro: desejo e resistência" - faz morada no núcleo do livro: a diferença cultural e a Outridade como commodities para usufruto de quem se reafirma hegemônico. bell hooks demonstra como a fascinação do Ocidente com o primitivo tem a ver com sua própria crise de identidade: 'do ponto de vista do patriarcado supremacista branco capitalista, a esperança é que os desejos pelo primitivo' ou que reforce e mantenha o status quo" (BORGES, in hooks, 2019, p. 15-18).
Now I see I was more an accomplice

to my own unrooting (NICHOLS, 2014)

Grace Nichols, em seu poema "Weeping woman", confere a voz narrativa a Dora Maar que, interpelando a Pablo Picasso, reivindica a posse, a prerrogativa da significação de seu nome, bem como as consequências daí decorrentes; no poema, Dora recusa algo que se lhe espera natural[izada]mente desde sua posição natural[izada] de musa de Picasso em vez de (ou antes de) mulher, artista, sujeita. Unrooting: cabe aqui a pergunta pela importância de roots no texto do poema (quiçá, do conjunto da coletânea de Nichols). Importante salientar, como apoio a esta interpretação, o jogo proposto nos versos entre once e now, entre como a percepção de enunciação se transforma à medida que passa a compreender o lugar de Picasso e, para além disso, seu lugar na obra de Picasso - daí o termo musa, para denominar uma mulher, sujeito, também artista, por vezes (re)conhecida apenas como "musa de", "mulher de". Talvez a esta enunciação, compreender implique perceber este unrooting: perceber now aquilo que, de uma posição-musa, se mostrava demasiado difícil de perceber - Glissant redivivo, quando se nota que a dominação, por vezes, se mostra em um lugar outro imperceptível às(aos) sujeitas(os).

Dora, Theodora, be reasonable, if it weren't for Picasso,

you'd hardly be remembered at all.

He's given you an unbelievable shelf-life.

Yes, but who will remember the fruits of my own life? (NICHOLS, 2014)

Pela primeira vez, a enunciação de Dora Maar retoma o próprio nome não por acaso (a nosso ver), versos antes, se fala no Minotauro (The white-clad ones / The Minotaur / wheeling me down / a labyrinth of wards -). A esta retomada do nome, se sucede uma estrutura construindo uma hipótese, na fórmula (if) + (condicional passado). Na fala de si, mediante terceira pessoa (ou, quem sabe, a pintura falando à mulher), há um esforço por pensar, refletir de modo a compreender as implicações de Picasso ou, expressamente, a recusa, now, em se limitar a um signo desprovido de sentido sem a presença de Picasso, do que decorrem os dois usos de own, um nesta mesma estrofe (my own life, também ligado à ação anterior de to remember) e em ao menos mais uma recorrência no 
poema, na parte 5 (Each time my own face cracks - não a da obra de arte; não a da musa; mas a minha, própria, a do sujeito).

Conforme ao conjunto das duas últimas partes do poema, a exigência a Picasso culmina com a evocação do nome e, desde ele e suas próprias significações, a enunciação reivindica seu próprio rosto (I want my face back) tal como anteriormente à apropriação de Picasso (the unbroken; não apenas parcialmente, na forma de the unbroken photography, mas de todo, unbroken, visto que as significações de seu nome se tornaram exógenas, porque tributárias de Picasso - vale a pena assinalar, nos versos anteriores, alguns sintomas desta nomeação exógena). A exigência desde o título da obra toma corpo, de modo a se desenvolver no restante do poema, assim como ao longo de toda coletânea: Picasso, I want my face back / the unbroken photography of it. Isso permitiria assinalar a importância do advérbio back desde o título do poemário (Picasso, I want my face back), em uma evocação que, antes de reivindicar retorno a um estado tido como original ou natural (e, cabe assinalar, assim tido de modo exógeno), reivindica o reconhecimento de uma sujeição, calcada em uma apropriação indevida - do rosto, do corpo e da prerrogativa de significar a si. Quando se percebe que Each time my own face cracks, para além do rompimento de uma estrutura prévia ou de uma integridade física dos sujeitos, se reconhece o rompimento da prerrogativa aos significados de si (it cracks), desde o momento em que se implementa a dominação mediante sequestro de tal prerrogativa; este verso permite interpretar a dominação como violência epistêmica de modo algum restrita a um momento histórico específico (justificando o uso de each time), mas constantemente ressignificada por novos atores - inclusive, a arte de vanguarda tributária deste contexto de dominação - assim como constantemente atualizada a violência epistêmica, quando se renovam os mecanismos de interdição aos significados de si. Isto opera quando Dora Maar se torna invisível enquanto musa de Picasso antes de sujeito de criação artística. Nesta interpretação, to crack se trata de uma ação referente ao corpo (quando percebemos o lugar do corpo, da forma do corpo feminino na obra de Picasso) mas, igualmente, à prerrogativa dos significados de si: Dora Maar cracks quando, perdendo sua condição de sujeita, assim como de se representar como sujeita, passa a ser reconhecida apenas mediante Pablo Picasso.

Nossas categorias de análise, mesmo textualmente negando a naturalização ora em jogo, amiúde selecionam e interpretam, em seus índices de leitura, em suas justificações analíticas, precisamente o que se pode identificar como "condición natural para algún tipo esperado de conducta o cualidad específica”. Esta regularidade em nossos procedimentos científicos de análises literárias, poderiam se mostrar recorrentes, quiçá mais recorrentes do que estejamos dispostas(os) a aceitar, em um quadro mais amplo de interpretação das literaturas de nossos Outros, em quaisquer níveis. Este problema da circunscrição da diferença ou, de modo mais específico, do quanto nosso trabalho científico (por vezes investido da posição do intelectual) corre o risco de circunscrever nossos Outros em nossas definições do que eles sejam (definições, portanto, exógenas), pode ser percebido em uma dupla dimensão, correspondendo ao silenciamento dos sujeitos, assim como à marginalização do estudo destes sujeitos no interior do campo. O "problema do Outro" nos compete enquanto ciência mas não enquanto problema, visto que dele, porque intelectuais, porque sujeitos cognoscentes, nos cremos, nos percebemos, [supostamente] estamos isentas(os). No interior do campo atinente a uma ciência debruçada sobre a cultura, sobre a nação, sobre os sujeitos e suas literaturas, nossos problemas circunscrevem posições legítimas ao passo que os problemas daqueles tidos como nossos Outros se limitam a "questões", tratadas por vezes de modo limítrofe e condescendente, como apêndices ou desvios do problema em jogo: daí decorre “el problema de las mujeres negras o indígenas' a ser incluido en la organización de paneles y encuentros del movimiento", amiúde em posição francamente externa ao debate central, à discussão do conceito, ao julgamento do mérito.

Por lo general la «cuestión» sigue siendo saldada en términos de «el problema de las mujeres negras o indígenas» a ser incluido en la organización de paneles y encuentros del movimiento y en algunos proyectos y programas de intervención compensatoria generalmente concebidos y administrados por feministas profesionales de clase media y de supremacía blanca del continente (MIÑOSO, 2014, p. 310)

Quando nos referíamos à crítica a abordagens caracterizadas por ambas como essencialistas, se salientara que, por vezes, os discursos científicos favoráveis a construções identitárias afro- pecariam, precisamente, quando incidem em "la reafirmación de una diferencia específica (naturalizada) de los grupos subordinados en relación al sujeto hegemónico" salvaguardando, mediante seus argumentos, "las mismas bases que las operaciones de dominio". Eis o que nos leva, sujeitas(os) negras(os), a jogar sempre com as pretas, [nos casos em que a resistência lograsse êxito 
ao ponto de facultar a prerrogativa do jogo] (ALVES, 2015). Ao menos, a evocação da possibilidade nos previniria deuma fetichização da resistência (resistência esta dinâmica e provisória, caso sigamos Glissant) de sujeitas(os) negras(os). Como contraveneno, há o risco de que nossas investigações científicas sobre o tema, assumindo a posição do Sujeito criticada por Spivak, advoguem a prerrogativa de definição das resistências e, em última instância, do Ser de sujeitas(os) investigadas(os). Eis uma ciência que, de modo de compreensão dos sujeitos, passaria, indevidamente, a instância definidora [e legitimadora] destas(es) sujeitas(os).

Como problema epistemológico próprio ao campo dos Estudos Literários no Brasil, observa-se que parte significativa de nossas investigações, no atual andamento do campo, adotam a categoria da resistência como premissa às literaturas negras [contemporâneas], independente de seu lugar de enunciação, de modo [ao fim e ao cabo] algo cartesiano: se literatura negra, logo resiste. Resistir se alçaria à categoria de ser, perfazendo um cogito; contudo, aqui se trataria de uma definição exógena, com todos os problemas anteriormente assinalados. Manter-se-ia, assim, uma perigosa distinção na qual caberia às literaturas negras - e, por extensão, às literaturas de nossos Outros - a tarefa de falar de si ao passo que às literaturas brancas - porque Sujeitos - caberia dizer universalmente o Homem e o mundo: em cena, uma vez mais, o conceito norteador de literariedade, na base de como definimos o escopo de nossa ciência. Primeiro corolário: do que decorreria a proposição de um critério [supostamente] estético às literaturas de nossos Outros, segundo o qual sua literariedade estaria diretamente proporcional a sua capacidade de dizer, universalmente, o Homem e o mundo. Segundo corolário: assim, faz sentido naturalizar uma regra, nova, introduzida por um dos jogadores [e, eventualmente, aceita pelo outro, como estamos examinando no problema em torno desta imagem] em que brancas(os) joguem sempre com as brancas e pretas(os) (ou, mais adiante: quaisquer não-brancas(os)), sempre com as pretas (ou, caso se prefira para fins de tratamento da imagem, as não-brancas).

Apostamos que, uma vez facultado a sujeitos negros o direito ao jogo (facultado/concedido/outorgado/licenciado, de tal modo que estes deveriam se sentir agradecidos pela dádiva do jogo), resolve-se o problema da isonomia do jogo e entre os jogadores. Tal aposta, contudo (hipótese de leitura), não pressupõe, quiçá não permita a pergunta sobre a legitimidade do jogo entre os sujeitos e, de modo subjacente, a pergunta sobre sujeitas(os) negras(os) enquanto sujeitas(os) de fato. A concessão ao jogo, naturalizando uma posição de resistência a estes sujeitos no tabuleiro, pode ser lida como um sintoma de que sujeitas(os) negras(os), no interior do jogo, não sejam tomados como tal; a presença não garante a posição-sujeito, caso desprovida da agência destas(es) sujeitas(os). No tabuleiro de nossa ciência, aos sujeitos que investigamos e buscamos compreender concedemos apenas a posição de resistência; ao fim e ao cabo, não nos observam em nossa legitimidade.

Somos apenas peças pretas.

\section{Conclusões iniciais: exercício sobre o tabuleiro de xadrez}

Suponhamos que se aceite uma hipótese, de fundo histórico, segundo a qual pretos (ou não-brancos) joguem com as pretas (ou não-brancas) porque chegaram depois ao tabuleiro ${ }^{35}$.

Cabe ressaltar que, do fato de que se joga com as pretas, não decorre, de modo algum, nenhum nível natural de submissão às brancas, tampouco a quem joga com as brancas. Ainda que se admita, como hipótese de trabalho, que pretos sempre joguem com as pretas, não decorre, como consequência, que as pretas adotem ou que devam adotar, necessariamente (em uma necessidade de fundo axiológico), uma estratégia de resistência. Propõe-se, no tratamento desta imagem, a ilegitimidade desta atribuição naturalizada de papeis aos sujeitos-em-jogo. Quando estabelecemos esta atribuição como premissa de nossas interpretações, no interior de nosso fazer-ciência, matamos a possibilidade de compreender a estas(es) sujeitas(os) como sujeitas(os), ao lhes negar a prerrogativa da agência.

São apenas peças pretas. E nós, Sujeitos (no sentido criticado por Spivak), movemos nossa ciência na ilusão de que somos árbitros e donos do tabuleiro.

Quisieron borrar nuestras huellas, quisieron silenciar nuestras voces, pero el cuerpo, cansado, desnudo

y maltratado por el látigo... ¡volvió a levantarse!

(HERRERA, in ZAMORANO, OCAMPO, 2010, p. 427-428)

35 Histórico, mas não necessariamente cronológico: não por acaso, em alguns tabuleiros artesanais de xadrez produzidos na região andina, se os vende como incas versus espanhois, e não o contrário, obedecendo a este princípio cronológico anteriormente suposto. 
As exclamações, ao final de cada estrofe, demarcam um movimento de pretas que não se resume, não pode ser esgotado em um modelo de resistência como nos propomos em nossas análises. Tal pista de leitura se ampara, também, nos verbos escolhidos para terminar cada estrofe: levantarse; reescribirse; multiplicarse; $\mathrm{e}$, ao final, $\operatorname{ser}^{36}$. Saliente-se que, nas duas primeiras estrofes, os verbos de ação (porque negros não são estado, tampouco fenômeno da natureza) recebem a contribuição do verbo volver, assim como do prefixo re-, na segunda estrofe: as literaturas negras não podem ser interpretadas necessariamente, no âmbito de nossa ciência, como um primeiro movimento de resposta a uma dominação soberana, tampouco a um movimento único, constante, naturalizado. A variedade de modos como Lorena Torres Herrera executa seus movimentos, ao final de cada estrofe (reservando o corpo da estrofe à construção da jogada, contextualizando sua jogada levando em conta a história da partida até ali) nos assinala o quanto nossa premissa de resistência pode encontrar dificuldades sérias em compreender as literaturas que investiga.

¿En efecto, qué ha sido la identidad, sino el sistema de regulación y control de las subjetividades, de manera que las y los individuos respondan a los patrones de poder preestablecidos? (Foucault, 1990). Cuando yo digo, soy mujer o soy negra, o soy las dos cosas, ¿a qué sistema de representación de mí misma estoy apelando? ¿Qué mecanismos de inteligibilidad estoy poniendo en marcha? ¿Qué significado tiene para quien me escucha el ser negra, el ser mujer? ¿Hay como tal, un ser "negro", una esencia negra? ¿Podemos en República Dominicana, en el Caribe, hablar de una identidad negra? (MIÑOSO, 1999)

Levados ao paroxismo, podem nos aprisionar nas expectativas das próprias identidades, de modo a propiciar a intensificação do racismo mediante uma representação natural[izada] daquilo que negras(os) devam ser; quiçá propiciando, igualmente, a segregação de sujeitas(os) negras(os) entre si, quando estas(es) não correspondam a este dever-ser.

Aqui, as brancas respondem de modo contundente à jogada das pretas:

- pretas estabelecem xeque: significação de identidades exógenas ${ }^{37}$;

36 Reconhecemos a necessidade de avanç̧ar sobre ele a análise deste poema, efetem artigo anterior, acerca da poesia de Lucrecia Panchano, publicado na revista Signo (BISPO; ALVES, 2015); na ocasião, recorrêramos ao conceito de resistência como nosso cavalo-de-batalha às análises literárias empreendidas. Por sua vez, em capítulo de livro publicado no mesmo ano (ALVES, 2015 - do qual provém a imagem norteadora do tabuleiro de xadrez), se iniciara um exame dos limites possíveis à resistência como categoria de análise a um corpus de literaturas negras americanas.

77 Dois exemplos literários: movimento de Tituba, em Moi Tituba sorcière..., compreendendo as implicaçoees
- brancas saem do xeque estabelecendo um contra-ataque, em xeque às pretas: identidades negras enquanto "sistema de regulación y control de las subjetividades, de manera que las y los individuos [negras] respondan a los patrones de poder preestablecidos".

A genialidade, perversa, deste contra-ataque incide sobre nossa aceitação, a contrapelo, da regulação e controle [exógena] entre nós próprios, conduzindonos ao paroxismo de definir nossas identidades natural[izada]mente negras, nossos ser-negro desde condições exógenas "de regulación y control de las subjetividades". Nem sempre nós próprias(os) definimos as regras daquilo que determinaria nossos ser-negro.

Em termos de análise literária, metodologicamente, poderíamos não mais interpretar significações de identidades exógenas, da parte de sujeitas(os) negras(os), como xeque-mate, sem que isso implique seu não reconhecimento como ato político de xeque; a buscar, nas narrativas interpretadas, como se daria o próximo movimento das brancas haja vista que, por não se tratar de um xeque-mate, o jogo ainda não terminara. Aqui, há um esboço a um procedimento metodológico, embora se deva tomar cuidado para não naturalizar pretos jogando com as pretas em vez disso, apontar os paroxismos a que nos leva tal naturalização.

Como consequência:

1. ao Sujeito cabe a dimensão da complexidade [humana], ao passo que a nossos Outros compete uma natural[izada] homogeneidade "de manera que las y los individuos respondan a los patrones de poder preestablecidos" - perversamente, pelo Sujeito mesmo.

1b. na imagem do jogo de xadrez, ao Sujeito cabe jogar sempre com as brancas visto que a nossos Outros sempre caberá, natural[izada]mente, jogar com as pretas ${ }^{38}$.

1c. o trabalho intelectual nos arvora à condição de jogar com as brancas, ainda que, fora da intelectualidade, amiúde sejamos reconhecidas(os) como Outro $^{39}$. E, enquanto intelectuais, nos regozijamos ao jogar com as brancas.

$\overline{\text { Prospero), do que decorrera sua busca do próprio nome, em Une tempête, de Aimé Césaire. }}$

38 Nossos porque nós intelectuais, seja mediante uma posição que se requer neutra ou seja nos outorgando uma posição de representação, tendemos a nos posicionar como Sujeito, por vezes em posição daquilo que Minoso assinalara como "la complicidad y el compromiso de nossos posicionamentos hegemonnicos que, embora no Sul, desenvolvem um compromisso epistemológico com o Norte "dado sus propios intereses de clase, raza, sexualidad y género normativos, legitimación social y estatus quo" (MINOSO, 2014, p. 319).

39 Como Alvaro de Campos, em "Poema em linha reta", ao se afirmar um técnico que só tem técnica dentro 


\section{Referências}

BENOIST, M. G. Portrait d'une femme noire. Salon de 1800, sous le titre Portrait d'une négresse. Disponível em: $<$ http://cartelfr.louvre.fr/cartelfr/visite?srv=car_not_frame\&idNotice=18871 $>$.

BHABHA, Homi K. O local da cultura. Tradução de Myriam Ávila, Eliana Lourenço de Lima Reis e Gláucia Renate Gonçalves. Belo Horizonte: UFMG, 1998 (Humanitas)

BISHOP, Elizabeth. Tituba speaks. Cincinnati Romance Review, Volume 40 (Spring 2016), Circum-Caribbean Poetics / Poéticas Circum-Caribeñas, Department of Romance Languages and Literatures, University of Cincinnati, p. 257.

BISPO, Ella Ferreira; ALVES, Alcione Correa. Enunciar desde nossos lugares, "para que nuestra identidad no se vaya al abismo". Signo. Santa Cruz do Sul, v.40, n. 69, p. 88-99, jul./dez. 2015.

CABRERA, M.; VARGAS MONROY, L. Transfeminismo, decolonialidad y el asunto del conocimiento: inflexiones de los feminismos disidentes contemporáneos. Universitas Humanística, v. 78, n. 78, 26 jun. 2014. Disponível em: <https://revistas.javeriana.edu.co/index.

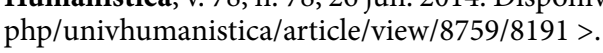

CONDÉ, Maryse. Moi, Tituba sorcière... Paris: Mercure de France, 2008.

GLISSANT, Édouard. Introductions. Le discours antillais. Paris: Gallimard, 1997, p. 14 (Folio Essais)

HERRERA, Lorena Torres. Siempre presentes. ZAMORANO, Alfredo Ocampo; ESCOBAR, Guiomar Cuesta. Antología de mujeres poetas afrocolombianas. Bogotá: Ministério da Cultura, 2010 (Biblioteca de Literatura Afrocolombiana, tomo 16). Disponível em: <http:// babel.banrepcultural.org/cdm/ref/collection/p17054coll7/id/15 >.

hooks, bell. Olhares negros: raça e representação. Tradução de Stephanie Borges; revisão técnica de Rosane Borges. São Paulo: Elefante, 2019.

LEAL, Lana Kaíne. "De la Barbade à l'Amérique et retour": memória, resistência e construções identitárias no romance Moi, Tituba sorcière..., de Maryse Condé. Dissertação (Mestrado em Letras) - Universidade Federal do Piaú, 2016. 86f.

MBEMBE, Achille. Introdução: o devir-negro do mundo. Crítica da razão negra. Tradução de Marta Lança. Lisboa: Antígona, 2014, p. 9-24.

MIÑOSO, Yuderkys Espinosa. Etnocentrismo y colonialidad en los feminismos latinoamericanos: complicidades y consolidación de las hegemonías feministas en el espacio transnacional. In: MIÑOSO, Yuderkis Espinosa; CORREAL, Diana Gómez; MUÑOZ, Karina Ochoa. Tejiendo de otro modo. Feminismo, epistemología y apuestas descoloniales en Abya Yala. Yuderkys de oino ma Miñoso Diana Gómez Correll Karina Ocho Muñoz (editoras). Popaýn: Editorias Espinosa Miñoso, Diana Gomez Correal, Karina Ochoa Muñoz (editoras). Popayán: Editorial
Universidad del Cauca, 2014, p. 309-323.

NICHOLS, Grace. Weeping woman. Picasso, I want my face back. Blooxdale Books Ltd., 2009/2014 (ebook edition).
Colonialidade da sexualidade: dos CONCEITOS

"Clássicos" aO pensamento crítico descolonial

Tatiane Borchardt da Costa

Miriam Cristiane Alves

A quem nos referimos quando debatemos sobre sexualidade humana? Esta representa uma entre várias outras questões que compõem o pano de fundo deste escrito. As linhas que se seguem versarão sobre a sexualidade humana em alguns de seus entendimentos "clássicos", aos quais agregaremos reflexões baseadas na perspectiva do pensamento crítico descolonial e em teorizações acerca das relações raciais.

O caminho percorrido para a produção dos questionamentos e reflexões presentes neste estudo advém da constituição do Núcleo de Estudos e Pesquisas Élééko, no Curso de Psicologia da Universidade Federal de Pelotas (UFPel), em 2017. A partir do mesmo e do aprofundamento a respeito do pensamento crítico descolonial, optamos pelo co-labor ${ }^{40}$ (LEYVA; SPEED, 2008) como uma possibilidade de investigação descolonizada e coletiva.

Trata-se de um estudo empírico cujas linhas serão preenchidas por indagações pessoais e por indagações produzidas no âmbito coletivo, isto é, em diálogo com o Núcleo de Estudos e Pesquisas Élééko. Tendo em vista a produção do conhecimento de forma plural, complexa e coletiva, pensaremos a sexualidade enquanto conceito e vivência, para que assim possamos nos aproximar de uma perspectiva descolonial acerca da sexualidade humana, a qual, por sua vez, possa fomentar dentre outras coisas, uma prática clínica/psicológica antirracista.

$\mathrm{O}$ artigo está organizado em seis seções. Na primeira, discutiremos a sexualidade humana enquanto conceito "clássico", acrescentando a este alguns questionamentos que orientam este estudo. Na segunda, iremos debater acerca do método, referencial teórico e o caminho escolhido para a produção deste artigo. As quatro seções seguintes, cuja primeira subdivide-se em dois tópicos, tratam dos principais assuntos discutidos nos encontros, ao passo que também se inclui a argumentação teórica e, no decorrer do texto, algumas considerações.

$40 \quad$ O termo, segundo as autoras, é oriundo do latim collaborare, que no dicionário de língua espanhola é definido como "trabajar con otra u otras personas en la realización de una obra" (LEYVA; SPEED, 2008, p. 34). 


\section{Quem é o Humano no Conceito "Clássico" da Sexualidade Humana?}

O conceito de sexualidade como fator constitutivo do ser humano nos é apresentado por Paulo Dalgalarrondo (2008). Em resumo, Dalgalarrondo (2008) nos apresenta uma visão biopsicossocial da sexualidade, ressaltando a importância da vida sexual vinculada à vida afetiva, à personalidade e aos símbolos culturais. Este entendimento de sexualidade em Psicologia, por mais universal que pareça ser, está usualmente atravessado por questões relacionadas ao conceito de gênero. Por exemplo, este mesmo autor cita dados que se referem ao comportamento sexual a partir do recorte que aborda diferenças entre homens e mulheres dentro e fora do Brasil (DALGALARRONDO, 2008).

Entretanto, por se tratar de um livro didático sobre a semiologia dos transtornos mentais, o autor aprofunda-se a partir do entendimento do adoecimento, de transtornos, síndromes, sinais e sintomas presentes na dimensão sexual (DALGALARRONDO, 2008). Contudo, se a discussão de gênero está presente na sexualidade, podemos nos questionar: que outros atravessamentos e construções também poderiam ser visibilizadas? E por que não aparecem neste tipo de literatura?

Michel Foucault (1988), um importante teórico sobre a sexualidade, nos apresenta a mesma como um dispositivo criado a partir de uma scientia sexualis que se desenvolveu ao longo do século XIX. O autor refere que, como correlata desta prática discursiva da "verdade sobre o sexo", a sexualidade humana se define como um campo de domínio e intervenção, como "palavra obscura que é preciso, ao mesmo tempo, desencavar e escutar". (FOUCAULT, 1988, p. 66).

Neste mesmo livro, Foucault (1988) assevera que os primeiros "alvos" do dispositivo da sexualidade e das técnicas médicas que se desprenderam deste foram a própria burguesia, ou ainda, as classes mais abastadas. Muito longe de atingir inicialmente aos pobres, de maneira oposta, "as técnicas mais rigorosas foram formadas e, sobretudo, aplicadas em primeiro lugar com mais intensidade nas classes economicamente privilegiadas e politicamente dirigentes" (FOUCAULT, 1988, p.113). A partir da família burguesa/aristocrática, problematizou-se a sexualidade das crianças e adolescentes, para então ser dado o enfoque à mulher, outro alvo corolário de tal dispositivo. Ao pensarmos que:
A burguesia começou considerando que o seu próprio sexo era coisa importante, frágil tesouro, segredo de conhecimento indispensável. A personagem investida em primeiro lugar pelo dispositivo de sexualidade, uma das primeiras a ser "sexualizada" foi, não devemos esquecer, a mulher "ociosa", nos limites do "mundo" - onde sempre deveria figurar como valor - e da família, onde lhe atribuíam novo rol de obrigações conjugais e parentais: assim apareceu a mulher "nervosa", sofrendo de "vapores"; foi aí que a histerização da mulher encontrou seu ponto de fixação (FOUCAULT, 1988, p.114).

Foucault (1988) chama-nos a atenção para a sexualização e para o controle da sexualidade da mulher. Mas que mulher é essa senão a mulher burguesa branca? Tendo o dispositivo surgido a partir da e para a burguesia, podemos entendê-lo como "um agenciamento político da vida, que se constituiu, não através da submissão de outrem, mas numa afirmação de si” (FOUCAULT, 1988, p.116, grifo nosso). Desta forma, e outrem? Quem são e onde entram estes “Outros” nesta história?

Este processo de construção do dispositivo da sexualidade está pautado pelo pensamento higienista, eugenista, - ao nosso ver também racista - e hegemônico da burguesia, que ao longo do século XVIII "converteu o sangue azul dos nobres em um organismo são e uma sexualidade sadia" (FOUCAULT, 1988, p. 119). O autor nos dá a entender que fez-se uma questão de tempo e oposição para tal dispositivo chegar às classes "inferiores", ou ainda, para a burguesia "reconhecer um corpo e um sexo nas outras classes - precisamente naquelas que explorava" (FOUCAULT, 1988, p. 119, grifo nosso). Vale nos perguntar, passado este tempo, como se configurou tal reconhecimento?

Em seu segundo livro, Foucault (1984) problematiza e faz sua análise acerca da constituição da moral instituída nos sujeitos no que se refere ao seu comportamento sexual desde a antiguidade greco-romana até o Cristianismo. $\mathrm{O}$ autor traz entre suas conclusões sobre a moral sexual grega que:

A reflexão sobre o comportamento sexual como campo moral não constituiu entre eles uma maneira de interiorizar, de justificar ou de fundamentar em princípios certas interdições gerais impostas a todos; foi sobretudo uma maneira de elaborar, para a menor parte da população, constituída pelos adultos livres do sexo masculino, uma estética da existência, a arte refletida de uma liberdade percebida como jogo de poder. A ética sexual que está em 
parte na origem da nossa repousava de fato num sistema muito duro de desigualdades e de coerções (em particular a respeito das mulheres e dos escravos); mas ela foi problematizada no pensamento como a relação, para um homem livre, entre o exercício de sua liberdade, as formas de seu poder, e seu acesso à verdade (FOUCAULT, 1984, p.220, grifos nossos).

Apesar de não vislumbrar uma imposição a todos, percebemos que a moral e a ética que nos é imposta inclusive nos dias de hoje no âmbito sexual fora pensada por e para uma população específica, com base nos “adultos livres do sexo masculino". Não somente isso, no entendimento ético-filosófico grego em relação ao comportamento sexual há dois papéis que podem ser distinguidos: "um papel que é intrinsecamente honroso e que é valorizado de pleno direito: é o que consiste em ser ativo, em dominar, em penetrar e em exercer, assim, a sua superioridade" e outro que se constitui "daqueles que devem ser os parceiros passivos dessa atividade" (FOUCAULT, 1984, p. 190).

Neste sentido, o ato sexual divide-se na "relação entre superior e inferior, aquele que domina e aquele que é dominado, o que submete e o que é submetido, o que vence e o que é vencido" (FOUCAULT, 1984, p. 190). Nesta posição de passividade, além das mulheres ${ }^{41}$, o autor faz referência aos sujeitos escravizados que devido a sua condição, "estão à disposição do senhor [...]", são assim "objetos sexuais a respeito dos quais não há nada a questionar" (FOUCAULT, 1984, p. 190).

Mesmo que nesta obra Foucault (1984) se refira a uma época histórica muito anterior ao período colonial e de escravização dos povos africanos, esta relação se aproxima àquela descrita por Angela Davis (2016) sobre homens brancos e o acesso ao corpo de mulheres negras, já que:

Uma das características históricas marcantes do racismo sempre foi a concepção de que os homens brancos - especialmente aqueles com poder econômico - possuiriam um direito incontestável de acesso ao corpo das mulheres negras (DAVIS, 2016, p. 180).

Voltando-nos às relações raciais no contexto colonial, podemos introduzir aqui o conceito de Colonialidade do Poder versado por Aníbal Quijano (2005) e desdobrado em Colonialidade do Ser (MALDONADO-TORRES, 2007) e Colonialidade do Saber (CASTRO-GÓMEZ; GROSFOGUEL, 2007), os quais 41 Foucault (1984) também faz alusão às relações de sexo e amor entre homens de status superior para/com rapazes jovens, às quais não necessariamente iremos nos ater neste estudo. nos ajudam a pensar sobre as estruturas de poder da modernidade/colonialidade fundadas a partir da ideia de raça e na hierarquização do humano.

Quijano (2005, p. 126), assim como outros autores do pensamento crítico descolonial, faz referência à construção de um "padrão mundial de poder capitalista, colonial/moderno, eurocentrado" que fomenta relações de poder capazes demarginalizar conhecimentos e sujeitos que não fazem parte deste padrão, ou seja, aqueles e aquelas que estão fora dos parâmetros, assinalados por Ramón Grosfoguel (2008, p.113) como "homem/heterossexual/branco/patriarcal/cristão/militar/capitalista europeu".

A Colonialidade se faz assim uma remodelagem e atualização do Colonialismo na contemporaneidade através da manutenção das estruturas de poder e hierarquia. María Lugones (2014), fazendo crítica aos escritos de Quijano, nos dirá que a Colonialidade, por sua vez, não se encerra na questão racial:

Es un fenómeno abarcador, ya que se trata de uno de los ejes del sistema de poder y, como tal, permea todo control del acceso sexual, la autoridad colectiva, el trabajo, la subjetividad/intersubjetividad y la producción del conocimiento desde el interior mismo de estas relaciones intersubjetivas. Para decirlo de otro modo, todo control del sexo, la subjetividad, la autoridad o el trabajo, están expresados en conexión con la colonialidad (LUGONES, 2014. p. 18).

Nessa perspectiva, Lugones (2014) nos apresenta o conceito de Colonialidade de Gênero, dizendo que a Colonialidade também permeia as relações de gênero e todo o controle ao acesso sexual, ao trabalho e demais dimensões. Vale ressaltar também que a constituição da Colonialidade produz na concepção de humanidade os binarismos: "superior e inferior, racional e irracional, primitivo y civilizado, tradicional y moderno" (LUGONES, 2014, p. 20). Sendo que por "primitivo" podemos entender, em um contexto evolutivo, um estado de não-humano/não-humanidade.

A autora ainda denuncia a invisibilização das mulheres negras em determinados entendimentos de "raça" e "gênero" dentro do pensamento crítico moderno, pois “En la intersección entre 'mujer' y 'negro' hay una ausencia donde debería estar la mujer negra precisamente porque ni 'mujer' ni 'negro' la incluyen. La intersección nos muestra un vacío” (LUGONES, 2014, p. 22). 
Ao pensarmos a sexualidade humana em seu entendimento "clássico" e histórico apresentado por Foucault $(1988 ; 1984)$ e relacionarmos tal discussão ao conceito de Colonialidade de Gênero inaugurado por Lugones (2014), observamos que se a sexualização e o controle da sexualidade da mulher se refere à mulher branca burguesa, e a elaboração de uma moral ética da sexualidade pauta-se no homem branco livre, podemos nos perguntar: quem então é o humano ao qual se refere esta sexualidade humana?

Ainda levando-se em consideração o recorte de gênero no conceito "clássico" da sexualidade e o que poderíamos chamar de "vazio conceitual" onde encontra-se a mulher negra, Sigmund Freud (1969a, 1969b) parece corroborar com o pensamento de Foucault (1988) no que se refere ao conhecimento que temos sobre o controle sexual da mulher branca. Inúmeras vezes, no início de sua teorização, Freud reforça a natureza "obscura" e incompreensível acerca da sexualidade feminina, como podemos observar nos trechos a seguir:

A importância desse fator da supervalorização sexual pode ser estudada em melhores condições no homem, cuja vida amorosa é a única a ter-se tornado acessível à investigação, enquanto a da mulher, em parte por causa da atrofia cultural, em parte por sua discrição e insinceridade convencionais, permanece envolta numa obscuridade ainda impenetrável (FREUD, 1969a, p. 11).

Sabemos menos acerca da vida sexual de meninas do que de meninos. Mas não é preciso envergonharmo-nos dessa distinção; afinal de contas, a vida sexual das mulheres adultas é um 'continente negro' para a psicologia (FREUD, 1969b, p. 132, grifo nosso).

Ainda que no texto original Freud (1926, p.55) utilize-se do termo "dark continent", utilizamo-nos do substantivo oferecido pela tradução para questionar retoricamente: se a vida sexual da mulher adulta branca compreendia um "continente negro" para este autor, o que Freud teria a dizer acerca de seu entendimento sobre a vida sexual de nós, homens e mulheres negros/as?

Frantz Fanon (2008) em parte nos auxilia nessa questão. Ele nos presenteia com uma reflexão psicanalítica acerca da constituição psíquica que fomenta as relações raciais. Contudo, por mais que o autor verse sobre a sexualidade tanto de homens negros e brancos, quanto das mulheres negras e brancas no contexto das relações inter-raciais, 0 mesmo conclui: "Admitindo que nossas conclusões sobre a psicossexualidade da mulher branca estejam corretas, poderiam nos perguntar que conclusões propomos para a mulher de cor. Não temos a mínima idéia” (FANON, 2008, p. 154).

Ainda que Fanon (2008) possa nos dar pistas no que tange a uma psicossexualidade humana que reflita a vivência de nós, homens e mulheres negras, permanecemos com um determinado "vazio" deixado por entendimentos "clássicos" acerca da sexualidade. Levantando questões como: de que formas nós, negros e negras, podemos nos pensar no que se refere à sexualidade humana estando muitas vezes à parte deste debate epistemológico? E em relação a nós, mulheres negras que vivenciamos a não-heterossexualidade, em que debates nos incluímos ou somos incluídas? Este estudo não busca necessariamente preencher este vazio, mas sim fomentar esta discussão que envolve raça, racismo, gênero, sexualidade e colonialidade, tendo como auxílio o pensamento crítico descolonial.

\section{Co-labor: um Movimento rumo ao Pesquisar Coletivamente}

A perspectiva teórico-metodológica deste estudo partiu do co-labor enquanto caminho para construção de uma investigação descolonizada (LEYVA; SPEED, 2008). Ao falar sobre a população indígena, Xochitl Leyva e Shannon Speed $(2008$, p.36) se utilizam do conceito de Colonialidade do Saber para fazer a denúncia ao caráter explorador das investigações produzidas junto a essas populações, cujo objetivoé extrair informações "para producir libros que benefician sólo las carreras académicas y universitarias sin devolver nada o casi nada, a la comunidad". Para tanto, as autoras problematizam a objetividade da ciência ea pretensa superioridade e imparcialidade do conhecimento científico que, por sua vez, irão contribuir com a construção da distância hierárquica entre pesquisador/a e objeto de estudo. As autoras fazem assim uma crítica à produção do conhecimento científico que se apresenta descomprometida com o fortalecimento das populações oprimidas e/ou com o enfraquecimento de tais opressões.

Nessa perspectiva, concebemos um percurso de pesquisa que foi construído ao longo da caminhada e em co-laboração com integrantes do Núcleo de Estudo e Pesquisas Élééko, os/as quais se constituirão como participantes- 
colaboradores/as deste estudo. Optamos pela companhia da coletividade e pela potência da multiplicidade de saberes e experiências das pessoas que integram o Núcleo; e apostamos na disposição e interesse das pessoas em nos acompanharem nessa caminhada. Assim, partimos do pressuposto que pesquisar não pode se tratar de penetrar ou invadir a experiência alheia para fins acadêmicos; exige um compromisso político e social com os sujeitos, grupos, comunidades enquanto protagonistas do processo de pesquisa.

O Núcleo de Estudos e Pesquisas Élééko está vinculado ao curso de Psicologia da UFPel e possui como uma de suas temáticas centrais o Pensamento Crítico Descolonial. É formado, fundamentalmente, por estudantes de graduação e pós-graduação de diferentes cursos da UFPel; seus encontros são semanais, com cerca de duas horas de duração, onde são apresentados e estudados diferentes temas com interface às relações raciais. Estamos inseridas no Núcleo, orientadora e orientanda deste estudo, desde seus primeiros encontros realizados no primeiro semestre de 2017. Um estudo, portanto, "desde dentro" (ALVES, 2012), desafiando-nos, mais uma vez, a produzirmos conhecimento acadêmico a partir de nossas experiências.

Com o intuito de preservar a identidade dos/as participantes-colaboradores/ as, cada um deles/delas escolheu um pseudônimo, de modo que alguns/algumas indicaram letras - TM, MT, AV, ML e BBD; e outros/outras indicaram nomes fictícios, baseados em personalidades significativas para si - Aguilar, Nola, Beatriz, Ifemelu, Clarice, Dandara, Santiago e Malcolm. Partindo deste total de participantescolaboradores/as, 10 autodeclaram-se, quanto à identidade de gênero, mulheres cisgênero e 3 homens cisgênero; Quanto à raça/cor: 9 autodeclararam-se pretos/as e 4 brancos/as. A faixa etária oscila entre os 20 e 48 anos de idade.

Vale ressaltar que este estudo faz parte de um projeto maior intitulado "A Violência do Inexistir: a construção de uma Clínica Política Decolonial”, do curso de Psicologia da UFPel, e que já fora aprovado pelo Comitê de Ética em Pesquisa da FAMED/UFPEL em 21 de junho de $2017^{42}$.

Para a produção do material empírico e do corpus de análise, realizamos três encontros, aqui denominados de rodas de co-labor, com os/as integrantes do Núcleo Élééko, dedicados às discussões sobre sexualidade humana. As narrativas assinado em duas vias pelos/as participantes-colaboradores/as, respeitando assim os aspectos éticos em pesquisa
realizada com seres humanos, conforme Resolucão no 510 , de 07 de abril de 2016 (BRASIL. MS, 2016). dos/as participantes-colaboradores/as foram gravadas em áudio e transcritas. Também foi utilizado o diário de campo para registro de acontecimentos, sentimentos e percepções. Ao longo das rodas de co-labor, buscamos estabelecer uma relação dialógica para a construção colaborativa de todas as etapas do estudo, avaliando conjuntamente, sempre que possível, se todos/as os/as participantescolaboradores/as estavam confortáveis com as discussões e com as etapas a serem seguidas/produzidas.

O percurso trilhado para a produção deste artigo deu-se de forma coletiva. O que fez com que seus resultados tenham por base uma discussão bastante ampla e complexa que, apesar de, por vezes, ser tensa, "pesada", "triste" e inquietante, também esteve repleta de momentos leves, de risadas, de compartilhamentos, de afetos e chimarrão ${ }^{43}$.

$\mathrm{Na}$ primeira e segunda rodas de co-labor, a pedido dos/as participantescolaboradores/as, sugerimos algumas frases para darmos início ao nosso processo de reflexão. Assim, inicialmente, dialogamos a partir de narrativas da sessão de “Temas Privilegiados”, do livro de Neusa Santos Souza (1983, p.61). Selecionamos ao todo dez narrativas do tema intitulado pela autora como "Representação de Si”, subtítulos "Fantasias e Estereótipos Sexuais"; "Representação do Corpo" e "O mulato: ser e não ser negro" (SOUZA, 1983, p. 61-64); e do tema "Das Estratégias de Ascensão", subtítulo "Não falar no assunto" (SOUZA, 1983, p. 65-66).

Durante as rodas de co-labor, as frases foram sendo sorteadas e, após a leitura para o coletivo, íamos refletindo e produzindo contribuições de cunho teórico/epistemológico e/ou vivencial. Ao final de duas rodas de co-labor, debatemos sobre quatro frases ao total, três da temática "Fantasias e Estereótipos Sexuais" e uma referente ao tema "Não falar no assunto".

Na terceira e última roda de co-labor, levando em consideração os assuntos já debatidos, oferecemos ao coletivo outros modos de expressão narrativa, os quais não são novidade para o funcionamento do Núcleo, de modo que fomos da palavra escrita ao audiovisual. Abrimos nossas discussões com as palavras no papel, e passamos então às palavras que acompanhavam a música/melodia e apresentação artística, mais precisamente no videoclipe da música "Braille", do rapper Rico Dalasam. Por fim, finalizamos com as palavras projetadas na tela,

43 "Chimarrão": "infusão que se prepara com as folhas secas da erva-mate" (Dicionário Didático de Língua Portuguesa, 2011, p. 178). Tal prática tornou-se comum no Núcleo de Estudos, expressa o acolhimento, ato de afeto e aproximação entre nós, integrantes. 
a partir de uma indagação feita pela ativista Winnie Bueno em sua rede social acerca da nomenclatura "lésbica".

O uso de diferentes expressões narrativas e narradores/as teve como inspiração a própria Neusa Souza (1983, p.61) que, ao coletar e transcrever seu corpus de análise, afirmou que a escrita "transforma em letra morta a experiência pessoal, direta, libidinalmente viva”. Concordando com a autora, porém em um ciclo inverso, transformamos a palavra escrita em vivência e experiência libidinalmente viva nos encontros de co-labor. Entretanto, como em um efeito cíclico, ao produzir este texto permanecemos com a difícil tarefa de não deixar nossas narrativas morrerem em vão.

Para a análise do material empírico partimos da emergência de significados das narrativas produzidas durante as rodas de co-labor e ao longo das leituras das transcrições de cada encontro. Assim, o processo de análise foi organizado em cinco etapas: 1) leitura preliminar do corpus de análise e identificação de temas emergentes; 2) leitura minuciosa do corpus de análise para confirmação e emergência de novos temas; 3) identificação de relações de interdependência entre os temas e agrupamento desses em eixos temáticos; 4) identificação de narrativas significativas e construção de um quadro que buscou interligar as narrativas, os temas e os eixos temáticos; 5) discussão e problematização dos eixos temáticos.

Ao longo da primeira e segunda etapa emergiram, da relação entre pesquisadora e corpus de análise, 16 temas, de modo que a busca pelas relações de interdependência entre eles resultou em seis eixos temáticos: Fábulas Sexuais: Quem são os/as personagens que compõem essa história?; Fábulas Sexuais: Que corpos esses fragmentos ficcionais montam?; Fábulas Sexuais: Que meios difundem e propagam essas histórias?; Como a Colonialidade da Sexualidade se expressa nos relacionamentos inter-raciais?; Como ficam o Cuidado e a Escuta/Relação Terapêutica?; Expressões sexuais/afetivas: Afinal, é possível descolonizar a sexualidade?. As discussões propostas a partir destes eixos serão apresentadas a seguir.
Fábulas Sexuais: Quem São os/as Personagens que Compõem essa História?

Se minha carne fosse vista diferente Se seu olhar fosse mais inocente Se eu não tivesse que ser forte Nem dependesse da sorte

Se antes do diabo que me pintam por ser o que sou Ou da deusa que cultivam pelo mesmo motivo Se eu fosse pessoa, PESSOA antes de mulata E se eu não tivesse que falar na lata? E se eu não tivesse que gritar?

Ainda ia ter graça me ver sangrar? E se eu quisesse me vingar?

Ou cês acha que nós não lembrava Do estupro, da escrava

Que cês ainda comemoram a ação Porque o resultado: A linda miscigenação (...) É que cês não gosta de mulher, cês gosta é de buceta. De preferência branca, mas com bunda de preta Até serve comer mulata, mas se for a que te acata

E os mano sempre diz que são todo errado, e aí quer pagar de aliado, mas cês tem que entender nosso lado, nós não atura papo de mandado Porque o papo não faz curva, aqui o papo é reto Cê vai se arrepender de me fazer de objeto Eu não tô aqui pra fazer seu membro ficar ereto Não se esqueça, aqui é muita treta Se teu pau é Ku Klux Klan, minha buceta é Pantera Negra (...) (Gabrielly Nunes, 2017)

Nos versos acima, é possível compreender um pouco da complexidade que é crescer e se entender como mulher negra no Brasil. Porém, antes de adentrar neste debate, consideramos importante discutir as criações ou criaturas que fomentam esta realidade: os conceitos de "raça", "efabulações", "estereótipos" e "fetiche".

Aquille Mbembe (2017, p.26) disserta sobre a construção histórico-social do conceito de "raça", e da atribuição do "substantivo Negro" (MBEMBE, 2017, p. 52). Essa construção, para este autor, está pautada por "processos de efabulação", 
ou seja, "apresentar como reais, certos ou exactos, factos muitas vezes inventados" (MBEMBE, 2017, p.30). Logo, o conceito de raça "não passa de uma ficção útil, de uma construção fantasista ou de uma projecção ideológica [...]” (MBEMBE, 2017, p. 27) inventada e repetida ao longo dos séculos.

De forma complementar, Mbembe (2017, p. 57) ainda introduz a conceituação da "Razão negra", que em um aspecto pode ser entendida como a "consciência ocidental do Negro" (MBEMBE, 2017, p. 58), pois a mesma:

[...] designa tanto um conjunto de discursos como de práticas - um trabalho quotidiano que consistiu em inventar, contar, repetir e pôr em circulação fórmulas, textos, rituais, com o objectivo de fazer acontecer o Negro enquanto sujeito de raça e exterioridade selvagem, passível, a tal respeito, de desqualificação moral e de instrumentalização prática (MBEMBE, 2017. p. 58).

Um conceito que se assemelha às "efabulações” citadas por Mbembe (2017) é o de "estereótipo", proposto por Stuart Hall (1997, p. 257) para instrumentalizar a produção da diferença. Hall (1997) define o estereótipo como uma prática representacional e/ou de produção de significados que se utiliza de um conjunto de características sobre determinada pessoa, "reduzem-na a estes traços, os quais são exagerados, simplificados e fixados sem possibilidade de mudança [...]" (HALL, 1997, p. 258). Neste sentido, o autor afirma que a estereotipagem "reduz, essencializa, naturaliza e fixa a 'diferença”' (HALL, 1997, p. 258, tradução nossa) ${ }^{44}$.

Além disso, o estereótipo funciona como um sistema de classificação que divide e produz exclusão, pois "simbolicamente fixa fronteiras, e exclui tudo aquilo que não pertence” (HALL, 1997, p. 258) ${ }^{45}$. A estereotipagem baseia-se, ainda, em uma estrutura binária/dicotômica, produzindo assim a divisão entre "Nós" e os "Outros", ao passo que também acontece de forma ambivalente e em situações onde há marcante inequidade nas relações de poder (HALL, 1997, p. 258).

Para este autor, o conceito de "fetiche" (HALL, 1997, p. 267) ilustra tal discussão na dimensão sexual, relacionando assim fantasia e projeção, desejo

$44 \quad$ No original: Stereotypes get hold of the few simple, vivid, memorable, easily grasped and widely recognized' characteristics about a person, reduce everything about the person to those traits, exaggerate and simplify them, and fix them without change or development to eternity. [...] stereotyping reduces, essentializes, naturali-

45 No original: It symbolically fixes boundaries, and excludes everything which does not belong. e repúdio. Este conceito também se configura uma prática representacional e basicamente significa transformar em objeto/objetificar, poderia-se dizer que o fetiche seria a redução da redução (HALL, 1997).

Lélia Gonzalez (1988) nos fala sobre a objetificação do corpo da mulher negra, utilizando-se da argumentação de Freud acerca do objeto parcial, a partir do contexto brasileiro. Nos textos de 1983 e 1988, a autora explana sobre a constituição político-cultural do Brasil, retratando o racismo estrutural em nossa sociedade, o mito da democracia racial e o que ela chamou de "pretuguês" (GONZALEZ, 1983, p 238), o que pode ser entendido como marcas africanas e/ ou africanização da língua portuguesa falada no Brasil. (GONZALEZ, 1988).

No que tange à discussão do objeto sexual e da mulher negra, a autora irá dizer que:

[...] é importante ressaltar que o objeto parcial por excelência da cultura brasileira é a bunda (esse termo provém do quimbundo que, por sua vez, e juntamente com o ambundo, provém de um tronco linguístico bantu que "casualmente" se chama bunda) (GONZALEZ, 1983, p 238).

Lélia Gonzalez (1983, p.238) ainda complementa nos dizendo que: "De repente bunda é língua, é linguagem, é sentido e é coisa”. No texto de 1988, a autora ressalta a presença da bunda na literatura e fantasias sexuais brasileiras, além do uso do biquíni "fio dental", o qual para ela tem como objetivo evidenciar este objeto parcial (GONZALEZ, 1988).

Beatriz, integrante do Núcleo de Estudos Élééko, lembra-nos sobre um dos efeitos da objetificação: "Lembra um pouco de objetificação também, tanto do homem negro quanto da mulher, de tirar a humanidade e ver só como símbolo sexual e nada mais que isso" (BEATRIZ, 2019).

Nesta perspectiva de não-humanidade, o homem negro também é transformado em objeto sexual. Malcolm e Santiago contribuem a partir de suas vivências enquanto homens negros no que tange ao olhar provindo da mulher branca sobre os seus corpos, calcado pela fetichização direcionado aos mesmos:

Até, é engraçado, porque eu também faço a leitura a partir da minha experiência, e aí isso tem relação com a discussão da masculinidade negra 
e o quanto ela é tóxica e recheada de fetichismo. E qual foi o momento que eu parei de ser enxergado como um nada e passei a ser enxergado como um objeto sexual, quando isso muda na tua vida e quanto isso influencia para as tuas relações com as outras pessoas, principalmente com mulheres brancas, o quanto tu percebes os olhares diferenciados. E é engraçado, porque tá talhado a tua vivência então tu percebe que de um certo momento tu não é nada, tu é completamente apagado, invisibilizado, a pessoa não nota a tua presença e aí passa para um olhar carregado de fetichismo. [...] Não dá pra generalizar, mas na maioria das vezes é muito. Também, depois de ler bastante coisa, depois de ter uma compreensão maior tanto da minha sexualidade quanto do mundo e a idade também, hoje, por exemplo, eu tenho uma percepção diferente do que eu tinha há três anos atrás. Então, perceber o quanto é carregado de fetichismo, todas as relações, isso não só relações sexuais, relações de amizade, relações de trabalho. Tudo tá carregado de fetichismo. [...] E mais louco que na minha experiência esse ser sexual tá ligado ao ser estereótipo criminal, então a partir do momento que eu passei a ser visto de uma forma exótica sexual eu também passei a ser visto como uma possível ameaça em qualquer espaço. Aí tu ficas com aqueles olhares ou de ameaça ou exótico sexual ali, tu ficas tentando entender o que que é que a pessoa tá pensando no momento (MALCOLM, 25 anos).

Tu nunca sabe se ela tá flertando com você ou se ela tá com medo de você (SANTIAGO, 32 anos).

Malcolm e Santiago explicitam o fetiche sobre o corpo do homem negro. Em determinado momento de sua vida, Malcolm passa de um "nada", um ser invisível para então ser visto como um objeto sexual. A percepção deste olhar sobre o seu corpo se deu após um período de amadurecimento e crescimento intelectual, com o qual, ele também afirma a presença do fetiche e objetificação nas demais relações interpessoais. Além de também estar atrelado à visão do sujeito negro como perigo e ameaça criminal, o que faz com que, como afirma Santiago, tal perspectiva alimente a dúvida se este olhar "tá flertando" ou se "tá com medo".

Fanon (2008, p. 146) salienta que quando a percepção do homem negro está baseada nesta construção estereotipada, observa-se que "não mais se percebe o preto, mas um membro: o negro foi eclipsado. Virado membro. Ele é pênis”. No que tange à ameaça criminal, o "medo racial, em particular, foi desde sempre um dos pilares da cultura do medo intrínseca à democracia liberal” (MBEMBE, 2017, p. 144). E, deste modo, produz-se não só o homem negro como objeto sexual, mas também como objeto amedrontador.

A Colonialidade reserva para nós, pessoas negras, o lugar de nãohumanidade, por conseguinte, supõe que somos coisa, somos objeto. Fazendo relação com a sexualidade, com o conceito de fetiche, por exemplo, nossa existência como pessoa, como refere Hall (1997, p. 266) torna-se fragmentada em "partes relevantes". A mulher negra é bunda, o homem negro é pênis. O "fio dental" visa evidenciar a bunda. Mas se bunda também é língua, como afirma Lélia Gonzalez (1988), língua como em linguagem, podemos fazer este caminho até a boca e sobre esta outra parte do corpo, por sua vez, Grada Kilomba (2019) nos diz algumas palavras. Ela argumenta que a boca simboliza o ato de falar e enunciar-se e que, em um contexto racista torna-se "o órgão da opressão por excelência" - já que representa o órgão "que as/os brancas/os querem - e precisam - controlar (...)". A autora faz referência inclusive ao uso da mordaça como instrumento de tortura e coerção no período escravocrata, tal qual uma "máscara do silenciamento" (KILOMBA, 2019, p. 34).

Esta mesma autora nos ajuda a entender o contexto em que esta sexualização e fetichização de pessoas negras é produzido. Sobre essa questão ela nos dirá que:

(...) no mundo conceitual branco, o sujeito negro é identificado como o objeto "ruim", incorporando os aspectos que a sociedade branca tem reprimido e transformando em tabu, isto é, agressividade e sexualidade (KILOMBA, 2019, p. 37).

A partir da noção de Colonialidade da Sexualidade produzida neste estudo, a imagem que nos salta é a de nosso corpo estilhaçado. O processo de nomeação deste corpo como "Negro" parte de uma "enorme ganga de disparates, de mentiras e de alucinações" (MBEMBE, 2017, p. 77). Podemos associar esta ganga às efabulações e aos estereótipos acerca de uma sexualidade falaciosa, uma "casca calcificada" (MBEMBE, 2017, p. 77) que promove, por sua vez, uma sexualidade exacerbada nas pessoas envolvidas por ela.

Fomos transformados em partes, porções, órgãos, os quais podem ser tanto evidenciados, quanto silenciados, dependendo da versão que melhor sustenta esta 
fantasiosa "carcaça", ou seja, "o que sobeja do corpo depois de ter sido esquartejado ou descarnado" (MBEMBE, 2017, p. 77). É nesta perspectiva que propomos o conceito de Colonialidade da Sexualidade, ou seja, um modo de produzir o corpo e a sexualidade por meio de um conjunto de fábulas que se perpetuam enquanto verdades.

\section{Fábulas Sexuais: Que Corpos esses Fragmentos Ficcionais Montam?}

O jogo só vale quando todas as partes puderem jogar Sou mulher, sou preta, essa é minha treta Me deram um palco e eu vou cantar

Canto pela tia que é silenciada

Dizem que só a pia é seu lugar

Pela mina que é de quebrada

Que é violentada e não pode estudar

Canto pela preta objetificada

Gostosa, sarada, que tem que sambar

(Bia Ferreira, 2018)

"Tia silenciada", "mina de quebrada", "preta objetificada" são alguns eufemismos dos invólucros criados por esta fragmentação do corpo da mulher negra. Levando em consideração que estas fábulas contadas e recontadas sobre nossos corpos negros obtém, como resultado, uma construção ontológica cuja função está em "substituir-se" ao nosso "ser, vida, trabalho e linguagem" (MBEMBE, 2017, p. 77), podemos então nos perguntar: se na Colonialidade da Sexualidade nossos corpos negros são compostos de fragmentos, que corpos estes fragmentos remontam e qual as suas particularidades? ML nos apresenta sua compreensão:

Acho que a mulher negra ainda tem duas faces, pelo menos na minha visão, a mulher negra mulata clara é essa tipo exportação e toda aquela fetichização sexual e a mulher negra mais preta é a subalterna, né? Para os serviços domésticos, para limpeza. Acho que tem essa distinção entre as mulheres (ML, 48 anos).

Lélia Gonzalez (1983) também assevera os estereótipos fomentados pelo racismo e sexismo no cenário brasileiro na década de 1980, muitos dos quais persistem até os dias atuais em relação às mulheres negras. A mulher negra, por exemplo, "naturalmente" é entendida como "cozinheira, faxineira, servente, trocadora de ônibus ou prostituta" (GONZALEZ, 1983, p. 226). São aspectos naturalizados que giram em torno de três grandes estereótipos: a mulata, a doméstica/mucama e a mãe-preta. A mulata representa um estereótipo sexual, enquanto a mucama/doméstica é a figura da mulher negra em posição serviçal, e a mãe-preta fomenta a imagem da ama-de-leite, da mãe que cuida (GONZALEZ, 1983).

Relacionando a discussão de Gonzalez (1983) com a de Hall (1997) acerca do conceito de fetiche, Nola afirma:

Acho que se assemelha à mulher negra no sentido de fascínio/repulsa. Tipo, no sentido de se é, por exemplo, uma mulher negra que é empregada doméstica tu tende a sentir repulsa, se ela é hipersexualizada é esse fascínio. Tipo, "ah, só a mulher negra sabe sambar!". É nesse sentido, eu acho (NOLA, 31 anos).

São muitos os desdobramentos do racismo para/com as mulheres negras. Malcolm nos ajuda a entender estes desdobramentos: "o efeito do racismo, ele é um monstro com diversos tentáculos, um tentáculo em cada especificidade, [...] todo mundo vai tá atingido e cada um com uma especificidade diferente". Ainda dentro desta questão, Malcolm explicita um dos efeitos no processo de sexualização e objetificação sexual do corpo da mulher negra, o qual pode diferenciar-se, segundo ele, entre estas mulheres conforme o tom de sua pele:

[...] influencia nessa fetichização da mulher negra que as mulheres negras mais retintas elas tem uma iniciação sexual na maioria das vezes mais tardia porque esse processo de né, de se tornar uma mulher ou, vamos dizer assim, um foco sexual dos homens é muito depois, porque inicialmente ela é só, é como se fosse um homem negro. E aí o "Não sou eu uma mulher?", porque inicialmente não. Eu percebi isso com pessoas próximas assim, o quanto... com parentes né, majoritariamente a gente tem esse tipo de conversa... o quanto mulheres negras mais claras sofrem processo de sexualização e de ter uma vida atrativa pro outro sexo muito antes do que mulheres negras mais escuras (MALCOLM, 25 anos). 
No entanto, as peculiaridades não estão somente no que se refere ao tom de pele, mas também no formato, ou na estética em que se encontra este corpo. Entre nossas discussões, foi afirmado que o homem negro gordo e a mulher negra gorda podem ter atribuído à sua imagem uma ausência de credibilidade, ou ainda um caráter cômico:

Eu fiquei pensando, há um tempo atrás eu li um texto de um homem negro que é gordo e ele fala como é muito diferente um homem negro que é magro, musculoso e aí a hipersexualização, e o homem gordo fica nesse lugar do engraçado. E fiquei pensando: o lugar da mulher negra também, tipo a que é mais retinta, gorda, ela é a Tia Anastácia, que acho que a Lélia fala [sobre o assunto] (CLARICE, 21 anos).

Uma vez eu fui analisar de fato qual era o trabalho dela [Falando sobre a artista Jojo Toddynho] e o que que as pessoas viam nela. E era muito essa coisa do humor. É um deboche. E se tu for olhar, ela canta, mas ela não canta mal, e ninguém fala disso. [...] Ela ascendeu na mídia por conta de que é engraçada e as coisas que ela tenta falar com verdade as pessoas acham graça, não levam nem em consideração (IFEMELU, 26 anos).

Segundo estes relatos, além de não fazermos parte do padrão "homem/heterossexual/branco/ patriarcal/cristão/militar/capitalista europeu" (GROSFOGUEL, 2008, p. 113) produzido pela modernidade/colonialidade, nós mulheres negras também sofremos diferentes impactos em relação à vivência de nossa sexualidade, conforme a forma/estética e tonalidade de nossos corpos. Pensando a Colonialidade da Sexualidade, podemos entendê-la não só como uma fragmentação do corpo, mas também como uma remontagem fictícia de múltiplos corpos, cuja feição influencia na atribuição do estereótipo e/ou fetiche. Sendo assim, tais composições não só potencializam a ação da própria Colonialidade da Sexualidade, como a perpetuam e retiram de nós as possibilidades múltiplas e emancipatórias de existência.

\section{Fábulas Sexuais: Que Meios Difundem e Propagam essas Histórias?}

Me escuta quem cê acha que é ladrão e puta Vai me dizer que isso não, não te lembra Cristo? Me escuta quem cê acha que é ladrão e prostituta Vai me dizer que isso não te lembra Cristo? $(2 \mathrm{x})$
Eles querem um preto com arma pra cima Num clipe na favela gritando: Cocaína! Querem que nossa pele seja a pele do crime

Que Pantera Negra só seja um filme

Eu sou a porra do Mississipi em chama Eles têm medo pra caralho de um próximo Obama Racista filha da puta, aqui ninguém te ama Jerusalém que se foda, eu tô à procura de Wakanda, ah

(Baco Exu do Blues, 2018)

Afirmamos que essas fábulas são contadas e recontadas, mas por quem? Mbembe (2017), ao falar sobre a propagação do "substantivo Negro", a consolidação do imaginário racista acerca de "África" e a introjeção do projeto colonial para o povo francês, descreve todo um processo de instauração do discurso racista na França, apontando como exemplo contribuições da ciência, da arte, da propaganda à época, da literatura, dentre outras ferramentas. $\mathrm{O}$ autor afirma que à época:

o tema da diferença racial normaliza-se na cultura de massas através do estabelecimento de instituições como museus e jardins zoológicos de humanos, publicidade, literatura, artes, constituição de arquivos, disseminação de narrativas fantásticas reportadas pela imprensa popular [...] e realização de exposições internacionais (MBEMBE, 2017, p. 114)

O uso destes dispositivos baseava-se no intuito de que paulatinamente "o francês comum fosse levado, por vezes sem se aperceber, a tornar-se um indivíduo racista, tanto no seu olhar, gestos e comportamentos como discurso" (MBEMBE, 2017, p. 113). Frantz Fanon (2008) também cita personagens ficcionais, obras e passagens literárias para montar sua elaboração acerca de como o racismo age na estrutura psíquica das pessoas negras, bem como denuncia a estereotipagem do homem negro na literatura e na publicidade.

Levando em consideração o que Malcolm nos diz sobre como "é importante lembrar do quanto a mídia tem um papel fundamental para formar a opinião pública de um país" (MALCOLM, 2019), explicitamos o debate sobre a mídia hegemônica e sua relevância na produção, reprodução e propagação dos estereótipos sexuais, tanto direta quanto indiretamente: 
[...] E essa fetichização também é super construída pela mídia. Nesse final de semana eu estava vendo um clipe da Madonna, desses clipes novos dela, dos últimos anos, tipo 2016/2015, [...] em uma cena de tourada e o touro ele é um homem negro e depois nas apresentações dela, dessa tour, uns homens negros, vários touros eram homens negros e que tinham uma [...] bem animalescos assim, de fazer como se fosse um touro mesmo, com chifres e tudo mais. E aí até comentei onde eu estava: "Nossa, olha isso!". E aí falaram assim: "Ah, é que esse aí era o namorado dela na época, ela quis mostrar ele." Aí eu: "Não, mas tem toda uma construção em cima disso, né” (AGUILAR, 23 anos).

[...] Também dá para pensar nisso, tipo, no quanto é naturalizado. [...] Te colocam em dois lugares: ou da hipersexualização ou do objeto. E, às vezes, se interligam na realidade, enquanto tu é objeto tu é hipersexualizada. Se a gente parar para pensar em quantas, sei lá, quantas obras ficcionais tratam [...] principalmente, do contexto do cinema brasileiro, assim, como tratam a mulher, a televisão brasileira em si. Por exemplo, a empregada, o filho do patrão assedia ela, então, além de hipersexualizada ela é um objeto de trabalho. Eles transformam essas duas figuras numa pessoa só, para ser aceito na televisão (NOLA, 31 anos).

A naturalização do discurso racista torna-se aparente quando Aguilaro denuncia e as pessoas ao seu redor buscam amenizá-lo. Nas rodas de co-labor, argumentamos que um dos possíveis efeitos que pode estar atrelado a essa naturalização em massa do racismo é a interiorização do discurso racista pelas próprias pessoas negras.

Mbembe (2017) explana sobre essa interiorização. Para este autor, o "substantivo Negro" preenche "as funções de atribuição, de interiorização e de subversão" (MBEMBE, 2017, p. 88). O "substantivo Negro" primeiramente atribui a negros e negras uma outra humanidade, marcada pela diferença. A interiorização, por sua vez, acontece quando estes sujeitos passam a habitar o lugar da diferença criado para si. Por fim, a subversão promove a transformação consciente deste “símbolo de abjeção num símbolo de beleza e orgulho" (MBEMBE, 2017, p. 88).

Ao interiorizar o discurso criado para marcar a diferença, tomando-o como próprio, assumimos um lugar de não-humanidade, de inferioridade. Fanon (2008, p.34) afirma que em todo povo que passa pelo processo de colonização nasce um "complexo de inferioridade devido ao sepultamento de sua originalidade cultural". Um dos fatores principais para que esse complexo ocorra é por meio da "interiorização, ou melhor, pela epidermização dessa inferioridade" (FANON, 2008, p. 28). Esta interiorização aparece de várias formas no que tange aos estereótipos sexuais, que além de fomentados pela mídia, são resguardados por outros discursos opressores como o sexista/machista:

Parece que o homem [negro] assume valorativamente bem o objeto que deram para ele. Assim como a mulher, ele se entende a partir do lugar subalterno que fizeram da gente [...] E aí até, no livro da Neusa Souza Santos fala sobre isso, o quanto as pessoas buscam esse lugar social criado para o negro. Meio que tu não consegue ultrapassar isso, por exemplo, tu não pode ser detentor de conhecimento, tu não pode ser detentor de uma família, de afeto, somente o afeto sexual, animal, como o Aquille fala. Acho que é isso. [...] O quanto a gente assume os papéis que foram criados. É tipo o álbum do Djonga, todo mundo chama "preto é ladrão", então eu sou ladrão, as pessoas chamam as mulheres negras de potencialmente mais transantes, então eu sou isso mesmo. A gente assume o lugar subalterno que é criado pra gente e aí, até que ponto isso é emancipatório? (MALCOLM, 25 anos).

Malcolm evidencia a interiorização do discurso racista acerca do papel sexual do homem negro e da mulher negra. Fanon (2008), com a interiorização e o complexo de inferioridade e Neusa Souza (1983), com o Ideal de Ego branco, falam sobre a busca das pessoas negras pela possibilidade ilusória de se embranquecer ao interiorizarem em si o discurso racista. Nas palavras de Neusa Souza (1983):

Passaram por nossos olhos, ouvidos e pele, fragmentos de discursos, colhidos das histórias-de-vida dos nossos entrevistados, onde ouvimos falar o negro enquanto sujeito que introjeta, assimila e reproduz, como sendo seu, o discurso branco. O discurso e os interesses. Tal façanha - a hegemonia dos interesses dominantes - é viabilizada pela eficácia dos mecanismos ideológicos cuja garantia, à nível psíquico, é assegurada por certas articulações estruturais e transações psicodinâmicas que cumpre elucidar. Assim é que se impõe o exame de dois conceitos fundamentais - Narcisismo e Ideal do Ego - forças estruturantes do psiquismo que desempenham um papel chave na produção do negro enquanto sujeito - sujeitado, identificado e assimilado ao branco (SOUZA, 1983, p. 32).

Observamos aqui o entendimento da construção psíquica das pessoas negras por meio de um complexo de inferioridade e de um Ideal de Ego branco. Para ilustrar esta questão, levamos em consideração pessoas que não só assumem 
o lugar criado para si, mas também se vangloriam e/ou entendem sua sexualidade a partir dos estereótipos sexuais criados pelo discurso racista:

Ela tem uma autoestima criada em cima da negação do corpo negro. E essa autoestima ela é extremamente frágil, no momento que ela se ligar que "opa, não é assim que funcionam as coisas", acabou toda a construção subjetiva que ela desenvolveu durante toda a vida (MALCOLM, 25 anos).

E isso eu vejo no âmbito profissional dessas meninas negras, as que conseguem um cargo em algum lugar. Porque "ai, eu fui escolhida!". Que nem uma conhecida aqui [na cidade] pra mim: "ah, eu consegui na [referindo-se a uma Concessionária], não sei o que, e olha que tinha várias meninas loiras lá e tal, e eu consegui!". E eu fiquei olhando pra ela [...]. Ela falando de um jeito, tipo eu, sei lá, "repararam que eu era mais gostosa" (IFEMELU, 26 anos).

É que os papéis sociais não se alteram, né? A pessoa cria uma estima criada em cima da negação dela. Então, "ah, eu sou pior do que as outras pessoas mas, naquele momento, por determinado fato, que é a minha sexualidade e só, eu fui tida como melhor pelo grupo dominante, que são os homens brancos que escolhem quem são as mulheres melhores". Ou seja, é um desserviço completo, um desserviço total para a autoestima da pessoa (MALCOLM, 25 anos).

[...] O quanto isso contribui para rivalidade feminina [...]. De pensar que a mulher negra ela vai se colocar no lugar do sexual e a partir disso ela vai fundar isso como sendo uma característica essencial para ela poder interferir em outros relacionamentos ou mesmo estando em segundo plano: "ah, ele tem a outra branca lá mas na hora de transar ou de ter uma relação eu sei que sou eu”. Sabe? Esse lugar. Isso contribui para a rivalidade feminina também (NOLA, 31 anos).

Percebemos, assim, como a Colonialidade da Sexualidade influencia na expressão da sexualidade das pessoas negras, assumindo papéis e discursos com base em estereótipos e efabulações acerca de seu próprio corpo e sexualidade. Esta interiorização, por sua vez, influencia na compreensão de si, na autoestima, nas relações interpessoais, nas relações de trabalho, dentre outras.

Logo, além da interiorização do discurso, como o caracterizam Mbembe (2017), Fanon (2008) e Neusa Souza (1983), há uma certa subversão do mesmo, como aponta o primeiro, ao nos vangloriarmos ou afirmarmos positivamente um discurso inventado. Contudo, se esta subversão tem por base inverdades criadas sobre a sexualidade de homens e mulheres negras, neste sentido, podemos reforçar o questionamento de Malcolm: “até que ponto isso" nos “é emancipatório?”.

Como a Colonialidade da Sexualidade se Expressa nos

Relacionamentos Inter-raciais?

Caro menino branco Esse nosso encontro pede a lucidez De saber o lugar que me encontro E você, por sua vez Se é pra andar ao meu lado, saiba que Alguém foi senhor Alguém foi escravo E, entre nós, esse espaço Pede alguns passos (Rico Dalasam, 2019)

O rapper Rico Dalasam apresenta em seus versos a complexidade de um relacionamento inter-racial entre dois homens. O livro de Neusa Souza (1983), por sua vez, traz diversos relatos de pessoas que estiveram ou estavam em um relacionamento inter-racial, partindo sempre de uma perspectiva heterossexual. A inter-racialidade nas relações faz brotar em nós diversas reflexões, como já colocara Fanon (2008, p.81), ao enunciar que um de seus objetivos era "tornar possível um encontro saudável entre o negro e o branco". Algumas constatações nas rodas de co-labor foram a presença marcante do complexo de inferioridade na pessoa negra que se encontra em uma relação inter-racial, bem como os desdobramentos acerca do fetiche ou objetificação sexual do corpo negro:

É complicado que isso acontece sem as pessoas perceberem, na maioria dos relacionamentos inter-raciais. Sempre o caráter subalterno que a pessoa negra carrega formulado na cabeça dela, desde que ela se criou, sempre vai fazer que ela se sinta um grau abaixo da pessoa branca, na maioria das vezes. [...] É, eu percebo que não foge muito, é sempre 
uma fetichização do corpo negro, ele sendo homem ou mulher, e uma subalternização psicológica que tá ligada a própria pessoa negra. [...] Não necessariamente a pessoa branca vai ter atitudes que façam com que a pessoa negra se sinta subalterna a ela, isso é uma construção histórico-política. Tá dado. As pessoas tem um senso de subalternidade como já dizia Fanon (MALCOLM, 25 anos).

Este relato/excerto corrobora tanto o pensamento de Fanon (2008) quanto com Neusa Souza (1983, p.27, grifo nosso), quando esta última afirma que "o irracional, o feio, o sujo, o sensitivo, o superpotente e o exótico são as principais figuras representativas do mito negro". No que se refere a dicotomia presente entre beleza e feiura no discurso racista, a narrativa a seguir apresenta como a lógica beleza-branca/feiura-negra se expressa nas relações inter-raciais, em se tratando aqui de uma relação inter-racial entre duas mulheres:

Me fez pensar numa coisa, numa situação, porque, ela fala sobre "branco de olhos azuis", e o estereótipo de beleza que a gente pensa, às vezes, a pessoa é só branca. E eu penso isso agora. Eu namorava com uma menina branca há 8 anos, sei lá, faz tempo. E aí um dia a gente estava num lugar, acho que num salão de beleza, e aí tinha uma menina negra também. $\mathrm{E}$ [...] eu lembro dela ter falado que a minha namorada era muito bonita pra mim. E ela [quem disse isso] era uma pessoa negra também. Agora eu penso nessa situação e fico assim [pensando] a minha namorada é só branca. [...] Me lembrei disso, desse lugar que a gente coloca pessoas brancas [...]. E como a gente se enxerga a partir daí, se ela é o topo do padrão de beleza quem eu sou dentro desse padrão? (NOLA, 31 anos).

Nola relata como sua namorada à época, por ser branca, era considerada "muito bonita" para ser sua companheira e questiona: se o padrão de beleza é branco, onde estamos enquanto pessoas negras dentro desse padrão?

A Colonialidade da Sexualidade também está presente nos relacionamentos inter-raciais, inclusive impondo uma ideia de "padrão ideal branco de beleza" cuja construção faz com que nós, pessoas negras, ponhamos à prova nosso corpo e aparência, tal qual o Ideal de Ego branco como refere Neusa Souza (1983). O relato de Malcolm e a contribuição de Santiago a seguir nos faz refletir sobre a hierarquia social estabelecida pela Colonialidade, bem como de que forma esta hierarquia se manifesta nas relações inter-raciais e acima de tudo, o que acontece quando os estereótipos sexuais mostram-se comprovadamente uma fábula:

Porque quando a mulher branca... isso aconteceu, na graduação eu me relacionei com uma ou duas mulheres brancas, e quando elas percebiam que tu não era unicamente um falo, tu detinha conhecimento e podia refutar coisas que elas diziam, estava no mesmo nível de conhecimento, aí a parte do falo vai pra segundo plano e tu passa a ser uma ameaça a brancura dela. Porque a partir do momento que tu tem conhecimento, ela não é mais superior naquele espaço, entende? Porque para a mulher branca, o homem branco é superior, por conta do machismo, e o homem negro não é superior, por conta do racismo. Então, dentro da escala hierárquica social seria a mulher negra, o homem negro, a mulher branca e o homem branco. E aí a mulher se relaciona entendendo que ela vai só se utilizar única e exclusivamente dos atributos sexuais do homem negro, nada mais. E aí quando ela percebe que não são só atributos sexuais, que existem outros atributos que assemelham o homem negro ao homem branco, aí naquela relação inter-racial, que ela se funda na desigualdade entre as pessoas, se funda em a mulher ser superior ao homem, esse papel na cabeça da mulher fica confuso e aí tu passa a ser uma ameaça ao lugar social dela. [...] E aí gera a repulsa. [...] Tu é considerado um não-ser, então a partir do momento que tu demonstra que tu não é só o símbolo sexual, aí tu meio que cria uma incógnita na cabeça da pessoa e ela fica tentando entender assim, "é outra coisa?", "o que que é?" e aí quanto entende é, como dizer, a exceção (MALCOLM, 25 anos).

Parece que quebra o encanto, a imagem que as pessoas tem. (SANTIAGO, 32 anos)

É. Aí é exótico. Até tudo, até a inteligência que a pessoa tem também é exótica (MALCOLM, 25 anos).

Aqui é possível retomar as figuras representacionais do mito negro apontadas por Neusa Souza (1983) e a construção da fetichização do homem negro já associada a Fanon (2008). Apesar de Fanon (2008, p. 82) afirmar enfaticamente que "De modo algum minha cor deve ser percebida como uma tara", espera-se do homem negro a potência sexual e a irracionalidade, única e exclusivamente. Quando existe a quebra/ ruptura da efabulação, há um processo de reconfiguração psíquica da pessoa branca na qual o discurso racista já fora paulatinamente introjetado, como já argumentou 
Mbembe (2017). Porém, acontece que a Colonialidade da Sexualidade se mostra eficaz, inculcada e de difícil desmantelamento, pois logo após a ruptura de uma fábula ou um estereótipo, o sujeito negro é rapidamente sujeitado à outro: neste caso, o de ser exótico, como afirma Malcolm no relato acima.

Como Ficam o Cuidado e a Escuta/Relação Terapêutica?

ANTIRRACISTA

"Anti" é contrário

Contra, oposto, oposição

Anti é luta, é vontade de viver e

Ecoar sempre que possível: \#EleNão!

"Racista" é quem não vê

É quem trata (a) gente como gado

É quem violenta e ainda assim é proclamado.

O "R"

não por acaso adicionado

Representa a (r)aiva

de quem sofre ou de quem na rua

é agredido ou insultado

De quem mesmo cansado

faz da raiva energia, calor,

afeto, arte e até fogo

Ser antirracista é lutar

Sabendo o gosto da derrota

E pro campo de batalha voltar, de novo

E seguir adiante pois

$O$ " $R$ " pode ser retirado de militar

Já que ser antirracista

também é ser militante.

(Tatiane da Costa, 2019)

Tendo em vista que o Núcleo de Estudos e Pesquisas Élééko possui uma maioria de estudantes do Curso de Psicologia da UFPel, em nossas discussões acerca da sexualidade e das relações raciais, também pensamos sobre o nosso papel enquanto futuros profissionais psicólogas/os. Principalmente no que tange à qualificação de nossa escuta para/com as relações raciais e o acolhimento ao sofrimento ocasionado pelo racismo.

Esta discussão está também presente na Resolução no.018/2002 do Conselho Federal de Psicologia (CFP, 2002), a qual aponta princípios éticos e orienta profissionais de Psicologia para uma atuação antirracista; bem como no documento Relações Raciais: Referências Técnicas para a Prática da(o) Psicóloga(o) (CFP, 2017), elaborado pelo Centro de Referência Técnica em Psicologia e Políticas Públicas (CREPOP). Sobre a ética e a postura de atuação antirracista em Psicologia, realizamos os seguintes apontamentos:

E tudo que a gente discute aqui e a partir da minha leitura enquanto um homem branco, homossexual, mas um homem branco ainda assim, faz eu [...] ter os sentidos mais aguçados para manejar isso na clínica, né? Do que, simplesmente encaixar essa pessoa numa estrutura, em determinado conceito clássico de psicologia [...] e violentar ela de novo, simbolicamente (AGUILAR, 23 anos).

Eu fiquei pensando também na responsabilidade que a gente tem enquanto psicóloga de escutar isso na clínica. Um discurso desses, e pensar como que isso se reflete de várias formas na vida de uma pessoa negra, de uma mulher negra. E a partir de várias coisas isso vai aparecer. E como que diferencia tu ter esse olhar, esse olhar sensível a essa questão racial (MT, 24 anos).

Acho que esse processo da clínica [...] tão importante quanto é acolher é validar esse sofrimento. Porque às vezes tu tá ouvindo e não ouve. $\mathrm{Na}$ verdade tu ouve, mas tu não escuta. Acho que acolher isso e validar é bem importante no nosso processo (ML, 48 anos).

Aguilar reforça a necessidade de qualificação de profissionais de Psicologia para que nós, pessoas negras, não sejamos violentadas novamente em um novo processo de universalização dentro do espaço clínico. Para tanto, Aguilar aponta a importância de espaços de discussão e MT e ML sinalizam a escuta sensível, o acolhimento e a validação do sofrimento oriundo do racismo. Dentre estes e outros depoimentos quanto ao manejo clínico no que tange às relações raciais, Aguilar também aponta a importância de refletirmos sobre o conceito de empatia, muitas vezes negligenciado: 
Isso me lembra muito a questão da empatia. Que comumente a gente atribui a "sentir no lugar do outro" sendo que existe uma impossibilidade de se sentir no lugar do outro. Ah, eu enquanto homem branco se sentir no lugar de uma mulher negra, não vou conseguir, existe uma impossibilidade. Aí eu gosto muito de uma subversão, assim, nisso de empatia que a [faz referência a uma Professora] estava falando sobre, a subversão que um psicanalista faz, ele é um psicanalista que sempre fala para o lado social, é um psicólogo social, falando que empatia seria sentir com o outro, né, estar junto. Acho que na clínica a gente pode tentar atuar assim dessa forma, "tamo junto", estou junto contigo aqui nesse processo de ressignificação, enfim. Revisitar esse sofrimento aqui nesse espaço agora clínico, de estar junto (AGUILAR, 23 anos).

Fanon (2008) nos auxilia a aprofundar a teorização sobre o papel da Psicologia e dos/as seus/suas profissionais no que tange ao sofrimento ocasionado pelo racismo. Sendo nosso papel, segundo este autor, o de "ajudar o negro a se libertar do arsenal de complexos germinados no seio da situação colonial" (FANON, 2008, p. 44). Além disso, Fanon (2008, p.95) acredita que: "Enquanto psicanalista, devo ajudar meu cliente a conscientizar seu inconsciente, a não mais tentar um embranquecimento alucinatório, mas sim a agir no sentido de uma mudança das estruturas sociais”.

Tal princípio norteador, ainda que pensado para a prática em Psicanálise, pode, de tal maneira, ser compreendido como uma postura ética para práticas profissionais que lidam com a saúde da população negra. Estar em contato, questionando e refletindo sobre as relações raciais, seja no âmbito da sexualidade ou não, mostra-se um importante aparato para o fomento de uma prática clínica/ psicológica antirracista.

Expressões Sexuais/Afetivas: Afinal, é Possível Descolonizar a Sexualidade?

Diga não ao racismo Diga não ao preconceito Diga não ao genocídio do meu povo preto Diga não à polícia racista
Diga não à essa militarização fascista Diga não

Não fique só assistindo Muita gente chora irmão enquanto você tá rindo Diga não! Diga não! (3x)

(Bia Ferreira, 2018)

Uma das questões que talvez mais tenha norteado o caminhar desta pesquisa foi a que compõe o subtítulo acima. A partir do momento em que dei início a minha vida sexual/afetiva ${ }^{46}$, fui percebendo estes "tentáculos" do racismo e da Colonialidade sobre a expressão de minha sexualidade. Obviamente que somente muito recentemente estes foram os nomes que utilizei para caracterizar tais fenômenos. Considero necessário retomar aqui o padrão "homem/ heterossexual/ branco/ patriarcal/ cristão/ militar/ capitalista europeu" (GROSFOGUEL, 2008, p. 113). Tal padrão cada vez mais mostrase estruturante em nossa sociedade e é desconcertante saber que possivelmente não me encontro em nenhuma dessas palavras. Não me encontro e ao mesmo tempo sou o “não", não-homem, não-branca, não-heterossexual, não.

E de negação em negação, vamos ao que não estava presente e o que não sabemos. Durante as rodas de co-labor, em que discutimos os depoimentos do livro de Neusa Souza (1983), nos aproximamos de narrativas que explicitavam os estereótipos sexuais apenas por uma perspectiva heterossexual. Com isso, nos direcionamos a outras referências e, assim, obtivemos o relato de Malcolm sobre a vivência do homem negro gay:

Eu conversava com dois meninos recentemente quando eu estava em [faz referência a uma cidade], que eles eram homossexuais negros e eles comentavam exatamente isso, o quanto no mundo homossexual masculino o homem negro tem esse papel estereotipado de performance sexual e tudo mais. Como é um mundo já estereotipado, não vou dizer, por excelência, mas muito estereotipado porque a comunidade gay, assim como os negros, se apropriaram do discurso que foi construído sobre elas. $\mathrm{O}$ mundo homossexual masculino negro, ele se apropria de dois discursos, e aí o quanto o jovem negro gay, homem principalmente, ele se cria através de destroços, porque ele tem que ostentar uma masculinidade por ser negro só que ele é gay, então essa masculinidade ela é parcial. Num relacionamento sexual, $46 \quad$ Faço o uso aqui da primeira pessoa do singular para apresentar a perspectiva da pessoa que digita, mas que certamente não produz esta argumentação sozinha: eu, Tatiane, ao longo de minha existência, enquanto que certamente não produz esta argumentação sozinha: eu, Tatiane, ao longo de minha existência, enquanto
mulher cisgênero, negra e não-heterossexual, trago nesta discussão indagaçôes provenientes justamente das vivências que obtive a partir deste lugar. 
quando ele é inter-racial, o homem negro ele ostenta uma masculinidade que não necessariamente ele tem, ou não necessariamente ele carrega como uma marca dele e isso fica meio que como uma máscara, como o Fanon diz. Então, o homem gay negro ele tem uma máscara masculina para se relacionar [...]. Eles têm uma dificuldade de se entregar ou de se relacionar sem estar embasado única e exclusivamente na marca sexual do relacionamento. [...] E aí o que esses rapazes falavam era que o quanto o gay negro ele tem que sempre afirmar essa sexualidade extrema. Então, qualquer ato sexual ele vai ser exacerbado, não necessariamente é isso que ele quer, mas é isso que ele tem que aparentar no relacionamento (MALCOLM, 25 anos).

Malcolm está na condição de um interlocutor, porém, sua fala em conjunto com o relato feito anteriormente sobre a lógica "beleza-branca/feituranegra" em um relacionamento inter-racial entre duas mulheres, nos apresentam uma pequena ideia de como a Colonialidade da Sexualidade age nos corpos das pessoas que enfrentam a complexidade de vivenciar uma sexualidade marcada não só pelo "substantivo Negro", mas também pelos substantivos da nãoheterossexualidade. Nesta perspectiva, aumentam os discursos opressores, e a interiorização dos mesmos resulta em um duplo Ideal de Ego com o qual se associar: branco e heterossexual.

Nola nos apresenta em sua narrativa a relação entre a mulher negra nãoheterossexual e as figuras representativas do mito negro apontadas por Neusa Souza (1983), no que tange à irracionalidade:

Mas [...] isso que o Malcolm falou eu penso que também acontece em relações homoafetivas. Porque a partir do momento que tu não é mais uma sapatão qualquer ali que tá no rolê, [...] quando eu falo que eu sou formada e faço outra faculdade é muito uma coisa: "Nossa, como assim?!" [...] Tu acabas se tornando uma ameaça, tu não é mais uma pessoa burra que tá ali, que tu vai ser usada. Acho que tem bastante semelhança nesse sentido (NOLA, 31 anos).

Voltando agora ao "não", à negação e ao não se encontrar nas palavras. Mbembe (2017) disserta brilhantemente sobre o conceito de "raça", sua construção e articulação, bem como sobre o "substantivo Negro". Tendo este autor em mente em nossas discussões, perguntamos-nos então sobre os substantivos da não-heterossexualidade:
[...] o termo "negro", como que é adicionado, também, será que xs meninxs que se relacionam com outrxs meninxs, da onde que veio [...]? A palavra [...]? Quem que inventou? Quem colocou? Vem disso também, né, porque a palavra "negro" é como ela disse, foi quem colonizou que colocou, mas, e [...]? Quem é que chegou e falou "ah, agora a partir de hoje o termo [...] vai para meninxs que se relacionam com meninxs"? ${ }^{47}$ (AV, 23 anos).

A título de fomentar a discussão, não saciá-la, trago por fim duas autoras que pensam as relações sexuais e a sexualidade de forma complementar. Audre Lorde (2013) e Sobonfu Somé (2007). Audre Lorde (2013, p. 10) nos fala sobre o erótico como uma força vital enraizada em cada uma de nós. O erótico, apesar de diferenciar-se do conceito de sexualidade, fora muitas vezes "difamado pelos homens e usado contra as mulheres", bem como o dispositivo da sexualidade apontado por Foucault (1988). Para Audre Lorde (2013), o erótico tem a ver com a profundidade do sentimento, com energia vital e a integração entre esta energia e as dimensões espiritual e política. A autora aponta para o fato de que:

Fomos ensinadas a desconfiar desse recurso, que foi caluniado, insultado e desvalorizado pela sociedade ocidental. De um lado, a superficialidade do erótico foi fomentada como símbolo da inferioridade feminina; de outro lado, as mulheres foram induzidas a sofrer e se sentirem desprezíveis e suspeitas em virtude de sua existência. Daí é um pequeno passo até a falsa crença de que, só pela supressão do erótico de nossas vidas e consciências, podemos ser verdadeiramente fortes. Mas tal força é ilusória, porque vem maquiada no contexto dos modelos masculinos de poder (LORDE, 2013, p. 9)

Sobonfu Somé (2007), por sua vez, nos conta sobre as relações de intimidade e amor na etnia Dagara, de sua região de origem, em Burkina Faso. No capítulo intitulado "Homossexualidade: guardiões do portão", a autora compartilha que "As palavras 'gay' e 'lésbica’ não existem na aldeia. Temos, sim a palavra 'guardião”' (SOMÉ, 2007, p.139). Sobonfu Somé (2007) versa sobre como as pessoas, para nós ocidentais, ditas "homossexuais" são vistas em sua comunidade. Assim como o erótico, em Audre Lorde (1984), a homossexualidade na etnia Dagara representa uma conexão maior entre o mundo terrestre e o mundo espiritual. Segundo Sobonfu Somé (2007), há nos $47 \quad$ O relato de $\mathrm{AV}$ está com algumas palavras ocultadas e com nomenclatura neutra a respeito do gênero propositalmente. Esta escolha se deu para que neste espaço seja possível pensarmos palavras como "lésbica", "gay", "homossexual", "sapatão", dentre outras. 
guardiões um papel social fundamental para a comunidade, o conhecimento detido por essas pessoas é valorizado e há nestas um propósito para existirem, propósito este que talvez tenhamos dificuldade para enxergar, já que nossa visão é atravessada pela Colonialidade da Sexualidade, a qual também impõe a heterossexualidade.

Retomando o conceito de Colonialidade da Sexualidade e a pergunta do início do subtítulo, a partir dos compartilhamentos e saberes produzidos nas rodas de co-labor, chegamos ao entendimento de que a Colonialidade atualiza-se no âmbito da sexualidade das mais variadas formas. Nos perguntamos também se seria possível desfazer as amarras feitas pela Colonialidade em nossa sexualidade. Neste sentido, Malcolm contribui nos dizendo que "Tem pessoas que não passaram por esse processo de se dar conta [...]. Quando não percebe o fetichismo que tem por trás de todas as relações. E é uma chavezinha assim, num momento da tua vida tu vais te ligar, ou não, né?" (MALCOLM, 25 anos).

Além desta possibilidade de conscientização, percebemos também que este processo está em nós e para pensá-lo, talvez possamos utilizar a analogia apresentada também por Malcolm: "É tipo um vírus, colonialismo é um vírus que tá na gente. Tu consegue, assim como o HIV, tu consegue diminuir a contagem do vírus no teu sangue, mas ele nunca vai deixar de tá lá".

Dentro dessa lógica, a Colonialidade da Sexualidade faz-se um paradigma estruturante de nossa compreensão pessoal. Levando em consideração o que foi exposto ao longo deste estudo, a Colonialidade da Sexualidade nos instaura um limite, ela nos instaura o padrão pelo qual somos forçados a nos apresentar, nos ater e expressar nossa própria sexualidade. Tal conceito pode, inicialmente, ajudar-nos a refletir acerca de nossa vivência, como negros e negras, no que tange a sexualidade, já que parece que os conceitos "clássicos" que referem-se a sexualidade não necessariamente nos abarcam, nem mesmo em nossas existências múltiplas, por exemplo, enquanto mulheres negras que vivenciam o lugar da não-heterossexualidade.

Não nos distanciando muito da ideia central deste estudo, em produzir reflexões, terminamos com a afirmação de algo que ainda não sabemos: tal como Malcolm afirma: "nessa lógica de estado não tem como ultrapassar, no meu entendimento, só se subverter a porra toda. Que eu também não sei como é que é" (MALCOLM, 25 anos). Concordamos e concluímos que, enfim, no que se refere à descolonizar a sexualidade, ainda não sabemos como, mas sigamos tentando com nossa existência e resitência.

\section{Referências}

ALVES, Míriam Cristiane. Desde Dentro: Processos de Produção de Saúde em uma Comunidade Tradicional de Terreiro de Matriz Africana. 2012. Tese (Doutorado em Psicologia) - Faculdade de Psicologia, Pontifícia Universidade Católica do Rio Grande do Sul, Porto Alegre, RS, 2012.

BLUESMAN. Intérprete: Baco Exu do Blues. In: Álbum: BLUESMAN. Intérprete: Baco Exu do Blues, et al. Selo: Independente, 2018. faixa 01. Disponível em: https://www.youtube.com/ watch?v=SoTkm5LkGKg\&t=604s. Acesso em: 02 jul. 2019

BRASIL. Ministério da Saúde. Resolução no ${ }^{\circ}$ 510, de 07 de abril de 2016. Dispõe sobre as normas aplicáveis a pesquisas em Ciências Humanas e Sociais cujos procedimentos metodológicos envolvam a utilização de dados diretamente obtidos com os participantes ou de informações identificáveis ou que possam acarretar riscos maiores do que os existentes na vida cotidiana. Brasília, DF: Diário Oficial da União, 07 abr. 2016. Disponível em: http://www.conselho.saude. gov.br/resolucoes/2016/Reso510.pdf. Acesso em: 01 jul. 2019.

CASTRO-GÓMEZ, Santiago; GROSFOGUEL, Ramón. Prólogo. Giro decolonial, teoría crítica y pensamiento heterárquico. In: CASTRO-GÓMEZ, Santiago; GROSFOGUEL, Ramón (Eds.). El giro decolonial: reflexiones para una diversidad epistémica más allá del capitalismo. Bogotá: Siglo del Hombre Editores; Universidad Central, Instituto de Estudios Sociales Contemporáneos y Pontificia Universidad Javeriana, Instituto Pensar, 2007. p. 9-23

CONSELHO FEDERAL DE PSICOLOGIA (CFP). Resolução CFP $\mathbf{n}^{\circ}$ 018/2002. Estabelece normas de atuação para os psicólogos em relação ao preconceito e à discriminação racial. Disponível em: https://site.cfp.org.br/wp-content/uploads/2002/12/resolucao2002_18.PDF. Acesso em: 01 jul. 2019.

CONSELHO FEDERAL DE PSICOLOGIA (CFP). Centro de Referências Técnicas em Psicologia e Políticas Públicas - CREPOP. Relações Raciais: Referências Técnicas para atuação de psicólogas/os. Brasília: CFP, 2017. Disponível em: https://site.cfp.org.br/wp-content/ uploads/2017/09/relacoes_raciais_baixa.pdf. Acesso em: 01 jul. 2019.

CHIMARRÃO. In: RAMOS, Rogério de Araújo. Dicionário didático de Língua Portuguesa: ensino fundamental 1.2 ed. São Paulo: SM Edições, 2011, p. 178.

DALASAM, Rico. Braille. [Intérprete e Composição]: Rico Dalasam. Direção: Alexandre Cintra e Gustavo Lucciola. Produção: Horizonte Produções, 2019. Videoclipe. Disponível em: https:// www.youtube.com/watch?v=Ga4LerPmyrk. Acesso em: 02 jul. 2019.

DALGALARRONDO, Paulo. Psicopatologia e semiologia dos transtornos mentais. 2 ed. Porto Alegre: Artmed, 2008

DAVIS, Angela. Mulheres, raça e classe. Tradução de Heci Regina Candiani. São Paulo: Boitempo, 2016.

FANON, Frantz. Pele negra, máscaras brancas. Tradução de Renato da Silveira. Salvador: EDUFBA, 2008.

FERREIRA, Bia. Diga não. [Intérprete e Composição]: Bia Ferreira. Produção: MarQ Audio Visual. São Paulo: Sofar Sound, 2018. Videoclipe. Disponível em: https://www.youtube.com/ watch?v=HyusmerTeUM\&t=202s. Acesso em: 02 jul. 2019.

FERREIRA, Bia. Não precisa ser Amélia. [Intérprete e Composição]: Bia Ferreira. Direção: Erica Pascoal. Produção: Ganga Produções. São Paulo: Fatiado Discos, 2018. Videoclipe. Disponível em: https://www.youtube.com/watch?v=psxSY400Pn8. Acesso em: 02 jul. 2019.

FOUCAULT, Michel. História da Sexualidade 1: a vontade de saber. 15 ed. Rio de Janeiro: Edições Graal, 1988. 
FOUCAULT, Michel. História da Sexualidade 2: o uso dos prazeres. 10 ed. Rio de Janeiro: Edições Graal, 1984.

FREUD, Sigmund. (1905). Três ensaios sobre a teoria da sexualidade. In: FREUD, Sigmund. Edição Standard Brasileira das Obras Psicológicas Completas de Sigmund Freud. v. VII. Rio de Janeiro: Imago, 1969a.

FREUD, Sigmund. (1926). A questão da análise leiga. In: FREUD, Sigmund. Edição Standard Brasileira das Obras Psicológicas Completas de Sigmund Freud, vol XX. Rio de Janeiro, Imago, 1969b.

FREUD, Sigmund. Die Frage der Laienanalyse. Leipzig, Wien, Zurig: Internationaler Psychoanalytischer Verlag, 1926.

GONZALEZ, Lélia. A categoria político-cultural de amefricanidade. Tempo Brasileiro. Rio de Janeiro, n. 92/93, p. 69-82, 1988.

GONZALEZ, Lélia. Racismo e Sexismo na Cultura Brasileira. Ciências Sociais Hoje, Brasília, ANPOCS, n.2, p. 223-244, 1983.

GROSFOGUEL, Ramón. Tradução de Inês Martins Ferreira. Para descolonizar os estudos de economia política e os estudos pós-coloniais: Transmodernidade, pensamento de fronteira e colonialidade global. Revista Crítica de Ciências Sociais, 80, p. 115-147, mar. 2008.

HALL, Stuart. Representation: Cultural Representations and Signifying Practices. London: Sage, 1997. KILOMBA, Grada. Memórias da Plantação - Episódios de racismo cotidiano. Tradução Jess Oliveira. 1 ed. Rio de Janeiro: Cogobó, 2019.

LORDE, Audre. Os Usos do Erótico: O Erótico como Poder. In: Textos escolhidos de Audre Lorde (Coletânea). Heretica Difusão Lesbofeminista. Edições lesbofeministas independentes, 2013.

LUGONES, María. Colonialidad Y Género: Hacia Un Feminismo Descolonial. In: MIGNOLO, Walter et al. Género y descolonialidad. 2.ed. Ciudad Autónoma de Buenos Aires: Del Signo, 2014. p.13-42

MALDONADO-TORRES, Nelson. Sobre la colonialidad del ser: contribuciones al desarrollo de un concepto. In: CASTRO-GÓMEZ, Santiago, GROSFOGUEL, Ramón (Orgs.). El giro decolonial reflexiones para una diversidad epistémica más allá del capitalismo global. Bogotá: Siglo del Hombre Editores; Universidad Central, Instituto de Estudios Sociales Contemporáneos y Pontificia Universidad Javeriana, Instituto Pensar, 2007. p. 127-168.

MBEMBE, Aquille. Crítica da Razão Negra. Lisboa: Antígona, 2017.

NUNES, Gabrielly. Vencedora SLAM grito filmes 2017 "GABZ". [Intérprete e Composição]: Gabrielly Nunes. Produção: Fernando Salinas. 2017. Videoclipe. Disponível em: https://www. youtube.com/watch? $\mathrm{v}=\mathrm{kZhPvruoeFw}$. Acesso em: 02 jul. 2019.

QUIJANO, Aníbal. Colonialidade do poder, eurocentrismo e América Latina. In: LANDER, Edgardo (Org.). A colonialidade do saber: eurocentrismo e ciências sociais. Perspectivas latino-americanas. Buenos Aires: CLACSO, 2005. p.117-142.

SOLANO LEYVA, Xochitl; SPEED, Shannon. Hacia la investigación descolonizada: nuestra experiencia de co-labor. In: SOLANO LEYVA, Xochitl et al. (Coord.). Gobernar (en) la diversidad: experiencias indígenas desde América Latina. Hacia la investigación de colabor. México: CIESAS, FLACSO Ecuador e FLACSO Guatemala, 2008. p. 34-59.

SOMÉ, Sobonfu. Homossexualidade: guardiões do portão. In: SOMÉ, Sobonfu. O Espírito da Intimidade: Ensinamentos ancestrais africanos sobre maneiras de se relacionar. Rio de Janeiro: Odysseus, 2003.

SOUZA, Neusa Santos. “Tornar-se negro”: As vicissitudes da Identidade do Negro Brasileiro em Ascensão Social. Rio de Janeiro: Graal, 1983.
AS CORES DO AFETO: UM ENSAIO SOBRE AS MULHERES NEGRAS NO CONTEXTO DAS RELAÇÕES AFETIVAS

Andréa Franco Lima e Silva

Muitas mulheres negras sentem que em suas vidas existe pouco ou nenhum amor. Essa é uma de nossas verdades privadas que raramente é discutida em público. Essa realidade é tão dolorosa que as mulheres negras raramente falam abertamente sobre isso. bell hooks ${ }^{48}$

A mulher negra está só. Essa é a afirmativa que escutamos em blogs, sites e grupos em redes sociais, peças de teatro, músicas e trabalhos acadêmicos. A mulher negra está só? Essa é a questão que nos colocamos, e que nos leva a indagar: quais relações podem ser estabelecidas entre raça, cor, gênero e afetividade?

bell hooks é professora, escritora, feminista e ativista social negra norteamericana, e em um texto bastante conhecido, "Vivendo de Amor" ${ }^{49}$, cuja citação abre o presente artigo, faz um resgate do papel das emoções e da afetividade na sobrevivência da população negra no período da escravidão, até os resquícios desse trauma nos relacionamentos socioafetivos desse grupo nos dias atuais. Embora se refira ao contexto norte-americano, a afirmação talvez não se encontre muito deslocada da realidade das mulheres negras brasileiras.

É o que declara Lucélia Sérgio, atriz e diretora, ao divulgar sua peça "Pari cavalos e aprendi a voar sem asas", em que trata do tema da afetividade da mulher negra, em entrevista ${ }^{50}$ ao Portal Geledés ${ }^{51}$ :

Não somos o ideal de beleza, não estamos em bons empregos para ajudar o companheiro a crescer, somos duras demais, ou cultas de menos, entre muitas outras coisas. Não estamos nem nas novelas! Uma negra bonita

\footnotetext{
$48 \quad$ bell hooks é graduada em Letras e Literatura, e ao longo da carreira especializou-se e tornou-se uma referência em questões de gênero, teoria feminista negra e estudos africanos e afro-americanos. A autora grafa seu nome sem iniciais maiúsculas, por isso será mantida essa grafia ao longo do texto.

49 Publicado originalmente em 1994.

50 Entrevista concedida à Maitê Freitas, publicada no site Geledés, em 27 de dezembro de 2014 51 Geledés - Instituto da mulher negra, organização da sociedade civil para a defesa de mulheres e negros e contra todas as formas de discriminação, fundado em 30 de abril de 1988.
} 
é vista como exceção para a maioria dos brasileiros, culta e inteligente, mãe de família e companheira,Z então... (SÉRIGIO, 2014, n.p.).

No mesmo sentido, Claudete Alves Souza (2008), autora da famosa dissertação "A solidão da mulher negra: sua subjetividade e seu preterimento pelo homem negro na cidade de São Paulo", que tornou-se referência no estudo do tema, em entrevista ao Portal Geledés ${ }^{52}$, explica:

A mulher negra enfrenta a solidão independente do extrato social. Não se trata de uma exceção, é a regra, um sintoma histórico que indica um comportamento real, as mulheres negras não têm (em sua grande maioria) a experiência do amor (SOUZA, 2014, n.p.)

Quando falamos em afetividade da mulher negra, estamos nos referindo a temas muito caros às Ciências Sociais: as interseções gênero e raça, sob uma perspectiva muito peculiar que são as relações afetivas, e que não se abstém da possibilidade de serem lidas como relação social. Mas como podem os afetos ser tema de interesse da Sociologia? Quando podem ser entendidos como forma de socialização, bem como nos dizer um pouco mais sobre as evidências empíricas que apontam a influência de fatores sociais na regulação das escolhas afetivas.

Ao debruçar-nos sobre as relações afetivas das mulheres negras, com um olhar sociológico, estamos concebendo essas relações como constituídas sob a influência de fatores raciais, sociais, históricos e de relações de poder. Tais fatores podem expandir a compreensão sobre raça e gênero a partir das narrativas pessoais, cuja subjetividade nos revela também um universo de significados, crenças e valores que correspondem a um espaço mais profundo nas relações sociais. Que aspectos, além das afirmadas desigualdade e solidão, perpassam essas relações afetivas? Qual o papel da afetividade como elemento de socialização e qual o peso de determinados marcadores sociais de diferença nas escolhas e nos destinos dessas mulheres?

Abordar a questão da afetividade da mulher negra abre as janelas para vários níveis de relação entre esses e outros marcadores de diferenças (idade, classe social, escolaridade, e outros), permitindo outra visão sobre a mulher negra, para além das descrições dos seus lugares nos indicadores sociais, comumente abaixo das médias. 52 Entrevista concedida à Maitê Freitas, publicada no site Geledés, em 27 de dezembro de 2014.
Tratar desse tema é fazer ecoar, no campo das pesquisas sociológicas, sua subjetividade e sua voz, que têm muito a dizer sobre as relações sociais e raciais brasileiras.

Assim, buscamos nesse ensaio refletir sobre as dinâmicas sociais que desembocam nesse cenário de afirmada desigualdade, através da compreensão da subjetividade da mulher negra em sua relação com a esfera afetiva da vida. O tema afetividade não alude apenas às relações conjugais, mas a todos os laços afetivo-sexuais constituídos e rompidos ao longo da vida, e estes são significados e ressignificados por essas mulheres conforme suas trajetórias. Como ressalta Claudete Souza (2008):

Ao me debruçar sobre a historicidade da mulher negra, vejo que sua trajetória, a partir da ruptura diaspórica africana até a contemporaneidade, foi permeada pela solidão. Também sempre foi demarcada por sucessivos revezes nas lutas de resistência contra as políticas de dominação escravagista, de segregação e de exclusão social, de assunção unilateral de responsabilidade familiares, de encontros e desencontros dialógicos amorosos na convergência do pertencer ou não pertencer, no direito de ser ou não ser. (SOUZA, 2008, p. 39).

Boa parte dos estudos sobre mulheres negras se debruçam sobre os aspectos materiais de suas vidas e pouco aludem ao universo subjetivo, ao sensível. Se, até hoje, negras e negros vivem uma condição social e econômica advinda tanto do passado escravagista quanto do racismo presente na sociedade, é possível dizer que esses dois elementos influenciam também na construção da subjetividade de mulheres negras e no modo como elas se relacionam.

Ana Cláudia Pacheco (2008), nesse sentido, afirma que:

se a discussão sobre raça mereceu atenção de vários intelectuais e pesquisadores(as) brasileiros(as) e estrangeiros(as) nas Ciências Sociais brasileiras, o mesmo não se pode dizer sobre a questão da afetividade e, muito menos, sobre a afetividade baseada em critérios raciais e de gênero. Poucas são as pesquisas que levam em consideração tal articulação, sobretudo no que toca a questão das escolhas de parceiros afetivos (PACHECO, 2008, p. 154).

Sobre a necessidade de debates sobre o tema, Luciene Longo (2011), em tese em que verifica se há associação entre as uniões intra e inter-raciais no Brasil e duas características sociodemográficas, a escolaridade e a religião, com base nos dados dos censos demográficos de 1980, 1991 e 2000, afirma: 
O estudo das uniões, sejam elas formais ou não, é importante por trazer a discussão sobre o papel da família e a determinação das escolhas dos indivíduos. Os aspectos inerentes ao mercado de trabalho, por exemplo, são mais bem entendidos se analisados com respaldo nessas escolhas e em seus efeitos na família (LONGO, 2011, p. 24).

Em seu trabalho, a autora revela o crescente número de relações inter-raciais, mas reitera que, no Brasil, as relações raciais endogâmicas (dentro no mesmo grupo racial) são a maioria. Luciene Longo (2011) conduz suas análises principalmente a partir do modelo de família nuclear, tendo por referência a relação conjugal.

Elizabeth Hordge-Freeman (2012) destaca que no Brasil não há muitos estudos sobre os processos de socialização racial, especialmente se considerarmos a perspectiva das microrrelações, como por exemplo o núcleo familiar ou as relações afetivo-sexuais.

Vivemos em uma sociedade em que a democracia racial e a harmonia das relações afetivas são mitos, e em que narrativas de uma pretensa igualdade racial ainda perduram no senso comum. Há ainda pouco entendimento sobre como esse discurso vai se formando, se reformando e se reafirmando nas relações privadas, pessoais. Compreender processos de microssocialização, como os são as relações afetivas, podem nos dizer muito sobre a dinâmica das relações raciais brasileiras, bem como sobre a posição e a perspectiva da mulher negra nesse processo. Do mesmo modo em que a afetividade não é apenas pautada pelo sentimento/amor, também não pode ser explicada satisfatoriamente por seu viés economicista/ utilitarista. Há nessas escolhas preferências sociais, políticas, culturais e étnicas que merecem ser objeto do interesse sociológico. O desejo e o envolvimento afetivo, como afirma Elisabete Pinto (2004), são permeados pelos valores e ideais estabelecidos pelo contexto social. Os vínculos amorosos são também determinados por concepções advindas de uma organização social machista e racista, e se explicam tanto pela história subjetiva das mulheres negras quanto pelo histórico-social em que o contexto de suas vidas está inserido.

\section{As relações raciais e os afetos: uma perspectiva sociológica}

Os primeiros estudos sobre as relações raciais envolvendo questões que talvez se aproximassem da dimensão afetivo-sexual eram voltados à temática da miscigenação, primeiramente vista como problema, e depois alçada à identidade nacional, até adentrar no universo do debate sobre as identidades raciais.

Entre o final do século XIX e o início do século XX a maior parte das pesquisas foi produzida sob a influência da corrente de pensamento conhecida como darwinismo social ou racismo científico. Nesse período se enxergava como "degenerescência" a miscigenação, e se colocava como um problema social e político a composição racial brasileira da recente República. De um lado, uma corrente antropológica e médica, em que se destacam Nina Rodrigues e Renato Kehl, via na miscigenação um fator de potencial atraso da nação. O problema identificado no campo das relações afetivosexuais dizia respeito aos casamentos e relações sexuais inter-raciais, bem como suas formas de enfrentamento, a fim de prevenir o avanço da miscigenação. Por outro lado, em uma corrente representada por Roquette Pinto e Oliveira Vianna a miscigenação era percebida como meio realizável do ideal de branqueamento da nação, ideologia que resultou no estímulo à imigração europeia no período.

Gilberto Freyre (2006), a partir da década de 1930, mantendo o foco nas relações sexuais e afetivas pelas lentes da miscigenação, passou a concebêla agora como parte componente e fundamental da identidade nacional e que se dava principalmente pela relação entre o homem branco e a mulher negra. $\mathrm{Na}$ interpretação freyriana, a relação entre homem branco/mulher negra era tanto marcada pelo erotismo quanto pela desigualdade ou mesmo brutalidade. $\mathrm{O}$ homem negro pouco aparece no processo de miscigenação e sua participação no mundo erótico, ao lado da mulher branca, é quase um tabu (MOUTINHO, 2004).

A miscigenação brasileira, para Freyre (2006), era componente próprio da miscibilidade e da adaptabilidade portuguesas, que teoricamente não sofriam com fronteiras raciais ou étnicas para se misturar sexual e culturalmente com outros povos. Por outro lado, estavam as mulheres indígenas e negras, a mercê dos desejos do colonizador. Dessa receita, se desenvolverá mais tarde o mito da democracia racial e o ideal de "morenidade" brasileiros. Convivendo com a representação do "mulato", o ideal mestiço, está a ideologia do embranquecimento. A miscigenação, afinal, teria um thelos, que seria diluir a cor negra da população brasileira. Eis a eterna ambiguidade, própria da miscigenação.

Donald Pierson (1971), ao estudar a sociedade baiana da década de 1930, se filia à Gilberto Freyre quando pensa sobre a miscigenação brasileira e explica sua origem 
pela falta de mulheres brancas no território brasileiro, durante o período colonial, aliada à "natureza aventureira" dos portugueses. A miscigenação, que na perspectiva do autor se naturalizou nas relações sociais brasileiras, foi também "favorecida", segundo ele, pelo domínio da mulher negra ou "mulata" nos empregos domésticos.

A partir da década de 1950, podemos identificar uma nova geração na sociologia das relações raciais brasileiras, em que as relações sexuais-afetivas passam a ser problematizadas como locus de desigualdade entre homens/mulheres negros(as) e homens/mulheres brancos(as). O homem negro aparece como ator fundamental no processo de miscigenação, e as relações entre o homem branco e a mulher negra passam a ser percebidas como relações de extraconjugalidade em que o papel erótico - e não familiar ou afetivo - da mulher negra é destacado:

O erotismo manifesta, sob uma aparência de aproximação das cores, o mais doloroso de todos os preconceitos: o estereótipo da preta como fonte unicamente de prazer, como um animal feito para a volúpia, que se repele desdenhosamente, uma vez satisfeito o desejo (BATISTE, 1959, p. 207 apud MOUTINHO, 2004, p. 2017).

As relações matrimoniais e a matrifocalidade da família negra brasileira também chamaram a atenção de Fernandes (1978). O sociólogo destaca as proibições sobre o casamento inter-racial e a permissibilidade em torno das relações extraconjugais, especialmente envolvendo as mulheres negras. Fernandes (1978) via nessas relações uma persistência das estruturas discriminatórias escravagistas e um instrumento de manutenção das relações racistas na sociedade brasileira. Observou também que a base de sustentação da família negra era a mulher, responsável pelo fomento econômico e educacional dos filhos (FERNANDES, 1978). A explicação para tal fenômeno estaria na desorganização social da população negra, problema que precisaria ser enfrentado com a integração do negro ao processo de integração econômica e modernização.

A partir da década de 1980, prevalecem os estudos quantitativos e se destacam as desigualdades criadas e recriadas por uma estrutura racista presente na sociedade brasileira, e não apenas reflexos de um sistema passado de escravidão, como propõem os estudos de Carlos Hasenbalg (1979). Edward Telles (2003) sugere que, devido ao racismo estrutural da nossa sociedade, o status social dos cônjuges negros, percebido como baixo no "mercado matrimonial", os obrigariam a pagar um alto preço para obter casamentos "vantajosos" (marry up) com parceiros mais claros. Ou seja, precisariam de muitas outras vantagens compensatórias, tais como maior escolaridade, e maior renda, para poder competir com pretendentes brancos. Nesse contexto, competindo com um contingente maior de mulheres brancas e pardas, a mulher preta, em geral, é a que teria menos a oferecer nesse "mercado".

Nesse sentido, o casamento ou relacionamento de homens negros e mulheres brancas, identificado como principal configuração das relações interraciais, passa a ser discutido sob a hipótese de estratégia para a mobilidade social desse homem. A mulher branca propiciaria o acesso social do homem negro, garantindo uma possibilidade de "escamoteamento" de seu padrão fenótipo, conferindo invisibilidade a sua cor (SOUZA, 2008). À maioria das mulheres negras restaria o preterimento.

Talvez possamos identificar nos novos estudos sobre a conjugalidade, a afetividade e a sexualidade da mulher negra nova abordagem de estudos sobre o tema. São pesquisas que buscam uma dimensão mais qualitativa e subjetiva dos fenômenos, em detrimento de uma abordagem economicista das relações, que fica em segundo plano. E é nesse conjunto que se encontra a presente reflexão.

Histórỉa, escravidão e relações de afeto: transformações e permanências

Claudete Souza (2008) busca na diáspora negra, que se deu principalmente entre os séculos XVI e XIX, a origem de um processo que afetará o caráter das relações familiares e de afetividade do grupo negro no Brasil, estabelecendo uma relação entre o quadro de solidão a que as protagonistas de seu estudo estão submetidas e o processo de escravidão no Brasil. Segundo a autora, o negro, quando espoliado de seu habitat é destituído ou seus meios de produção e, especificamente, de seu próprio corpo, de seus sentimentos e de seus afetos (SOUZA, 2008). É também o que afirma Giacomini (1998, p. 37):

Era o senhor que decidia sobre a possibilidade e qualidade da relação entre o homem e a mulher escrava, sobre se haveria ou não uma vida familiar, se casados ou concubinados seriam ou não separados, se conviveriam com os filhos e onde, como e em que condição morariam. 
A escravidão imporia uma ruptura das configurações familiares e afetivas, transformando o caráter dessas relações de maneira intensa e permanente. De acordo com Claudete Souza (2008), o homem negro, essencial à produção agrícola, foi excluído e marginalizado do grupo familiar, fazendo surgir famílias matrifocais. Ao feminino foi outorgada a condição de centralidade e autoridade na assunção da permanência e guarda do lar ou da família, em contraposição à ausência definitiva ou flutuante da figura paterna.

Em outra direção se encontra Robert Slenes (1999). A partir de uma pesquisa realizada baseando-se nos registros eclesiásticos, ele percebeu um número elevado de casamento entre escravos, e afirmou que os escravos possuíam leis próprias de convívio familiar. Segundo Robert Slenes (1999, p. 111):

A 'família' é importante para a transmissão e reinterpretação da cultura e da experiência entre as gerações. O grupo subalterno que tem instituições familiares arraigadas no tempo e redes de parentesco real e fictício não está desprovido de 'formas de união e de solidariedade', muito menos de uma memória histórica própria; portanto, suas interpretações da experiência imediata nunca serão idênticas às do grupo dominante, nem poderão ser previstas a partir de um raciocínio funcionalista.

Nesse aspecto, o estudo de Manolo Florentino e José Góes (1997) nos mostra que, por considerarem que a família é em parte responsável pela paz nas senzalas, os senhores de escravos referem-se a ela de forma positiva, e famílias eram constantemente constituídas no interior das senzalas.

Angela Davis (2016), seguindo esse raciocínio ao abordar as relações privadas no período da escravidão nos Estados Unidos ${ }^{53}$, defende que a vitalidade familiar da população negra sobreviveu aos horrores da escravidão, mas o papel das mulheres ainda é fixado pela possibilidade de serem esposas. Não há um enforque multidimensional dessa mulher.

O trabalho ocupou e ocupa um espaço enorme na vida da mulher negra. O trabalho compulsoriamente ofuscou qualquer outro aspecto da existência feminina negra. As mulheres, assim como os homens, eram unidades rentáveis de trabalho. Sob esse aspecto, não havia grandes distinções de gênero.

$53 \quad$ Apesar de a autora referir-se à realidade norte-americana, acreditamos que as reflexões e a hipótese levantadas são perfeitamente possíveis como pontos de investigação também sobre o Brasil.
As formas de opressão e submissão ajustadas às mulheres eram os abusos sexuais, que nem sempre eram apenas formas de subjugar e explorar a mulher e seu corpo, mas também serviam a uma disputa de virilidade do colonizador contra o homem negro, que não tinha como proteger sua mulher e suas filhas. Da mesma forma que a mulher negra não era considerada "mulher", visto que não lhe atribuíam os limites do "sexo frágil", ao homem negro era negada qualquer manifestação de autoridade ou virilidade, e não cabia a ele o ideal de "chefe de família". Ambos não poderiam assumir papéis sociais tradicionais, pois não caberia aos negros e negras sequer um estatuto humano (DAVIS, 2016). Para Angela Davis (2016), é na vida doméstica que os escravos podiam resgatar a sua dimensão humana. $O$ trabalho doméstico, para a família escrava, era o trabalho para si, o trabalho realizado com sentido.

A população escrava era produto e produção. Não havia, para a mulher negra, espaço para o feminino. Tendo em vista o ideal de mulher do século XIX - a dona de casa dócil, as mulheres negras eram praticamente uma anomalia. Restava a essas mulheres, no máximo, um estereótipo feminino ligado ao ambiente doméstico, que é o da mulher servil e da "mãe negra" das crianças brancas. A mulher negra guarda ainda hoje qualidades consideradas tabus para um ideal de feminilidade, segundo Davis (2016).

bell hooks (2010) afirma que o sistema escravocrata e a organização social racista que parte dele criaram entraves para que os negros nutrissem seu crescimento espiritual. Na expressão de hooks (2010), esses entraves se desdobraram em uma verdadeira ferida emocional na população negra, que dificulta aos negros e negras o desenvolvimento do amor interior (a estima de si) e, da mesma forma, a estima daquele que é o seu espelho.

Nesse sentido, saber reprimir as emoções foi - e ainda é - um instrumento de sobrevivência à escravidão e, posteriormente, ao racismo. Em um contexto em que se está submetido às forças de repressão das emoções como garantia de resistência, o amor torna-se um luxo. Por outro lado, as formas de pobreza e marginalização a que foram submetidas as pessoas negras no período pósabolição contribuíram para a confusão ou talvez a fusão entre os significados de amar e prover. Os atos e expressões de afetos seriam assim substituíveis pelos meios materiais de subsistência: amar os filhos, por exemplo, se confunde em darlhes o que comer, e isso basta como aprendizado afetivo (hooks, 2010). 
Para Audre Lorde (2007), não é possível que os negros e negras continuem seguindo suas vidas e negando os sentimentos mais profundos, pois isso é viver mutilado. São nos sentimentos que residem a nossa criatividade e a nossa força para enfrentar o mundo. Sentimentos não são um luxo, mas uma necessidade. $O$ silêncio é muito mais opressor e se calar não faz desaparecer o medo. $\mathrm{O}$ silêncio, como afirma Audre Lorde (2007), não nos protege.

A mulher negra é acusada de não atender a um ideal de feminilidade. Essa seria, segundo Lorde (2007), uma das razões levantadas pelos homens negros para preferirem manter relacionamentos com as mulheres brancas. Audre Lorde (2007) nos questiona: mas deveríamos manter algum ideal de feminilidade? O que deveria ser questionado não é se a mulher negra é feminina o suficiente, mas esse próprio ideal em si, que vem de uma cultura patriarcal e eurocentrada.

\section{Gênero, identidade e interseccionalidade}

Um dos principais pontos de interseção do feminismo com a questão racial e a afetividade está relacionado às percepções relativas à corporeidade da mulher negra. No que toca especialmente a essas mulheres, suas características fenotípicas estão a todo tempo associadas a estereótipos raciais negativos e tais características estão também relacionadas à suposição de um comportamento sexualizado e quase servil dessa mulher, crença essa que reproduz a concepção colonial da mulher escravizada, pronta para servir ao senhor. A mulher branca, em contrapartida, está vinculada a uma perspectiva de gênero como aquela que é "boa para casar" (SOUZA, 2008). Ana Cláudia Pacheco (2008, p. 292), nesse sentido, afirma sobre suas entrevistadas:

O corpo foi uma das categorias mais acionadas nas relações sociais construídas pelas informantes acerca dos sentidos atribuídos às suas escolhas afetivas e à ausência de parceiros fixos. Foi no corpo que as mulheres perceberam, sentiram e ressignificaram a solidão.

Nilma Gomes (2005) nos apresenta a associação que é feita entre a aparência física (cor, cabelo, traços físicos) e os lugares de inferioridade social. A autora afirma que, "no Brasil, quando discutimos a respeito dos negros, vemos que diversas opiniões e posturas racistas têm como base a aparência física para determiná-los como "bons" ou "ruins", “competentes" ou “incompetentes", "racionais" ou "emotivos" ” (GOMES, 2005, p. 45).

Esses temas, que podem ser tratados no campo do feminismo interseccional, são fundamentais à compreensão sistemática do racismo e do sexismo, tão intrínsecos à dinâmica dessas relações, tema central da presente discussão. A interseccionalidade foi assim definida por Crenshaw (1989, p. 177):

A interseccionalidade é uma conceituação do problema que busca capturar as consequências estruturais e dinâmicas da interação entre dois ou mais eixos da subordinação. Ela trata especificamente da forma pela qual o racismo, o patriarcalismo, a opressão de classe e outros sistemas discriminatórios criam desigualdades básicas que estruturam as posições relativas de mulheres, raças, etnias, classes e outras.

Os estereótipos vinculados à representação social são fontes inesgotáveis de violência contra as mulheres negras e também confinadores sociais. Patricia Collins (2016) argumenta também que o tema central do pensamento feminista negro é o legado da luta, visto que todas as mulheres negras compartilham a comum experiência de comporem uma sociedade que as desprivilegia. Essa experiência sugere que certos temas característicos sejam proeminentes do ponto de vista destas mulheres. A autora aborda, ainda, a forma como os estereótipos vinculados à representação social são fontes inesgotáveis de violência contra as mulheres negras (COLLINS, 2016).

As desigualdades e as representações de gênero e raça aqui brevemente apresentadas permeiam as interações afetivas dessas mulheres, conforme afirma Ana Cláudia Pacheco (2008). Portanto, esse é um tema crucial para o entendimento das relações entre raça e gênero no Brasil.

O lugar do afeto: escollhas e destinos

É impossível dizer que escolhas do campo afetivo e sexual sejam mera questão de gosto pessoal, como se este estivesse completa e plenamente desconectado do universo social em que o indivíduo está inserido. A relação com o outro está permeada de valores, ideais, representações, contextos sociais que merecem ser conhecidos. 
Dentre as pesquisas mais recentes destacadas como referência sobre o tema da afetividade da mulher negra, e muito referenciadas nessa proposta de trabalho, estão a dissertação de Claudete Souza (2008) e a tese de Ana Cláudia Pacheco (2008). Ambas tratam do impacto dessa seletividade sobre as mulheres negras sob o viés da solidão. Pacheco (2008) se concentra nas mulheres negras baianas, ativistas e não ativistas de algum ramo do movimento negro, e que estão sozinhas, sem nenhum tipo de relacionamento amoroso. Souza (2008), por sua vez, realizou sua pesquisa na cidade de São Paulo, e se debruçou sobre a solidão causada pela rejeição do homem negro em relação às mulheres de mesma classificação racial. Ambas as pesquisadoras afirmam a condição de solidão da mulher negra, embora esse termo possa ser reapropriado e ressignificado pelas mulheres, inclusive de uma experiência negativa a uma experiência positiva.

Esses trabalhos problematizam principalmente o significado de solidão, bem como buscam demonstrar como o tema se relaciona de maneira dinâmica com os marcadores sociais como os de gênero e raça.

O que defendemos é que a mulher negra, ao propor essa discussão, nos obriga também a refletir sobre o que significa estar em um relacionamento. E a partir dessa reflexão, podemos descobrir facetas negativas sobre as formas através das quais os modelos patriarcais de relação afetivo-sexual submetem as mulheres, o quanto podem inibir sua autonomia e emancipação e o quanto estar em um relacionamento pode ser, inclusive, solitário. Nos trabalhos de Souza (2008) e Pacheco (2008) percebemos que há um limite de expectativas e exigências sendo traçado pelas mulheres. Ou seja, a dor da solidão não se compensa com outras dores. Ora, não são poucos os relacionamentos abusivos e violentos a que estão submetidas as mulheres.

Colocar a solidão da mulher negra como questão é abalar os paradigmas e pensar novas formas de ser e de viver em relação com os outros. É também, por uma nova chave, pensar a solidão não como destino, mas como possível escolha ou, ao menos, como possibilidade de criar, para si, outros afetos, outras formas de se relacionar e, por que não, novas maneiras de estar no mundo.

\section{Referências}

AZEVEDO, Thales de. As elites de cor numa cidade brasileira: um estudo de ascensão social, 2. ed. Salvador: EDUFBA, 1996.

COLLINS, Patricia Hill. Aprendendo com a outsider within: a significação sociológica do pensamento feminista negro. Revista Sociedade e Estado, v 31, n 1, p 99-127, jan./abr. 2016.

CRENSHAW, Kimbelé. Demarginalizing the Intersection of Race and Sex: A Black Feminist Critique of Antidiscrimination Doctrine, Feminist Theory, and Antiracist Politics. University of Chicago Legal Forum, v. 1989, n.1, 1989. Disponível em: https://chicagounbound.uchicago.edu/ uclf/vol1989/iss1/8. Acesso em: 06 out. 2019.

DAVIS, Angela. Mulheres, raça e classe. São Paulo: Boitempo, 2016.

FERNANDES, Florestan. A Integração do Negro na Sociedade de Classes. 3. ed. São Paulo: Ática, 1978. v.2.

FLORENTINO, Manolo; GÓES, José Roberto. A Paz das senzalas: famílias escravas e tráfico atlântico, Rio de Janeiro, 1790-1850. Rio de Janeiro: Civilização Brasileira, 1997.

FREYRE, Gilberto. Casa Grande e Senzala. 48. ed. São Paulo: Global, 2006.

GIACOMINI, Sônia Maria. Ser escrava no Brasil. Revista Estudos Afro-Asiáticos, Rio de Janeiro, n.15, p. 145-170, 1998.

GOMES, Nilma Lino. Alguns termos e conceitos presentes no debate sobre relações raciais no Brasil: uma breve discussão. In: BRASIL. Educação anti-racista: Caminhos abertos pela Lei Federal n. 10.639/03. Brasilia, MEC, Secretaria de Educação Continuada, Alfabetização e Diversidade, 2005. p. 39-62.

HASENBALG, Carlos Alfredo. Discriminação e desigualdades raciais no Brasil. Rio de Janeiro: Graal, 1979.

hooks, bell. Vivendo de amor. Tradução de Maísa Mendonça. Geledes [Online]: 09 mar. 2010. Disponível em: <https://www.geledes.org.br/vivendo-de-amor/>. Acesso em: 23 jun. 2019.

HORGE-FREEDMAN, Elizabeth. "What's Love Got to Do With It?: Racial Features, Stigma and Socialization in Afro-Brazilian Families". North Carolina, EUA, 2012. Tese (Doutorado em Filosofia) - Department of Sociology. Duke University, 2012.

LONGO, Luciene Aparecida Ferreira de Barros. Uniões intra e inter-raciais, status marital, escolaridade e religião: um estudo sobre a seletividade marital feminina, 1980-2000. 2011. Tese (Doutorado em Demografia) - Universidade Federal de Minas Gerais, Belo Horizonte, 2011.

LORDE, Audre. Sister Outsider: Essays and speeches. Berkeley: Crossing Press, 2007.

MOUTINHO, Laura. Razão, “Cor” e Desejo: uma análise comparativa sobre relacionamentos afetivo-sexuais "inter-raciais” no Brasil e na África do Sul. São Paulo: UNESP, 2004.

PACHECO, Ana Cláudia Lemos. "Branca pra casar, mulata pra f.... e negra pra trabalhar": escolhas afetivas e significados de solidão entre as mulheres negras de Salvador, Bahia. 2008. Tese (Doutorado em Ciências Sociais) - Universidade de Campinas, Campinas, 2008.

PIERSON, Donald. Brancos e Pretos na Bahia. 2. ed. São Paulo: Nacional, 1971.

PINTO, Elisabete Aparecida. Sexualidade na Identidade da Mulher Negra a partir da Diáspora Africana: O caso do Brasil. 2004. Tese (Doutorado em Psicologia Social) - Pontifícia Universidade Católica de São Paulo, São Paulo, 2004. 
SÉRIGIO, Lucélia. A afetividade da mulher negra: Parte 1. Entrevista concedida à Maitê Freitas. Geledés [Online]: $27 \mathrm{dez}$. 2014. Disponível em: <http://www.geledes.org.br/afetividade-damulher-negra-parte-1/\#ixzz3n3Xi1PeE>. Acesso em: 23 jun. 2019.

SLENES, Robert Wayne. Na senzala, uma flor: esperanças e recordações na família escrava, Brasil sudeste, século XIX. Rio de Janeiro: Nova Fronteira, 1999.

SOUZA, Claudete Alves da Silva. A solidão da mulher negra: Sua subjetividade e seu preterimento pelo homem negro na cidade de São Paulo. São Paulo, 2008. Dissertação (Mestrado em Ciências Sociais) - Pontifícia Universidade Católica de São Paulo, 2008.

A afetividade da mulher negra: Parte1. Entrevista concedida à Maitê Freitas. Geledés [Online]: 27 dez. 2014. Disponível em: <http://www.geledes.org.br/afetividade-da-mulhernegra-parte-1/\#ixzz3n3Xi1PeE>. Acesso em 22 jun. 2019.

TELLES, Edward. Racismo à Brasileira: uma nova perspectiva sociológica. Rio de Janeiro: Relume Dumará e Fundação Ford, 2003.
POTENNCIAS AUTO-ANTROPOLÓGICAS: REFLEXÕES DE UMA ESTUDANTE NEGRA SOBRE TEORIAS ANTROPOLÓGICAS CONTEMPORÂNEAS

Aline de Moura Rodrigues

\section{Como me Reencontrei com esta Escrevivência ${ }^{54}$}

Preciso contextualizar de onde parte este ensaio. Na verdade, ele é um reencontro. Produzi-o por ocasião de uma disciplina - uma das mais instigantes entre as que cursara, até então, no bacharelado em Ciências Sociais. Naquela circunstância, meus olhos de aprendiz brilhavam perante as descobertas e aprimoramentos da escrita etnográfica como potência poética e científica. Ao mesmo tempo em que tive a oportunidade de conhecer cinco mulheres incríveis, que em seus processos formativos reinventaram as possibilidades de ensinar sobre temas complexos da teoria antropológica contemporânea, como autoridade etnográfica, ontologias múltiplas, mútuas inventabilidades no campo, entre outras abordagens.

Escrevo hoje de um lugar no qual, naquele semestre em 2017, eu não imaginava que pudesse estar no futuro próximo. Estou em San Cristóbal de Las Casas, no estado de Chiapas, na parte sudeste do México, conhecendo mais uma série de possibilidades ontológicas e relações entre epistemologias e cosmologias, que se confrontam e se complementam - às vezes, gerando memórias de outros aprendizados e outros escritos. Voltei ao meu baú dos pensamentos e colhi uma flor, igual àquela que um dia a professora Juana nos fez questionar. Permiti-me questionar a mim mesma e complementar uma série de reflexões que seguem vivas e me movimentando no caminho da superação das ideias cristalizadas socialmente sobre o que, como e até onde posso ir.

\section{Reinventando a Cultura da Minha Escrita}

Acho importante iniciar este ensaio com um agradecimento que não fiz pessoalmente. Ter conhecido e discutido algumas contemporaneidades antropológicas $54 \quad$ Agradecimento especial às mestras e doutoras que nesta ocasião, durante seu processo de conclusão do mestrado e doutorado, compartilharam de maneira intensa, aberta e gentil, as dúvidas e os saberes. Obrigada Alessandra Estevam da Silva, Ana Milena Horta, Juana Lucia Cabrera Prieto e Elisa Oberst Vargas. Especial abraJean Segatta. 
com professoras maravilhosas, como as que tive, foi imensamente importante para a antropóloga que estou lutando para me tornar. Vocês talvez não saibam, mas me fortaleceram muito a cada aula e me fizeram acreditar mais em mim mesma e nas minhas colocações, como as críticas inclusive. Sentir-me capaz de compartilhar o que estava pensando sobre as propostas de debate foi algo novo para mim, que sempre preferi calar. $\mathrm{O}$ silêncio sempre nos foi subjetivado como única possibilidade perante um mundo baseado epistemologicamente na aceitabilidade do racismo, do sexismo, do machismo e da idolatria da normatividade branca, heterossexual e cisgênera.

Sobre esta subjetivação, Grada Kilomba (2016) nos apresenta uma historicização dos processos materiais e imateriais utilizados para interiorizar o silenciamento nas pessoas negras. Partindo da descrição de um instrumento de tortura utilizado para punir pessoas escravizadas com a impossibilidade de comer e falar, chamado de máscara, Grada Kilomba (2016) propicia importante reflexão sobre as construções de lugar e possibilidades sociais de existência das pessoas negras no mundo. Sempre imagino uma conversa entre Grada Kilomba (2016) e Djamila Ribeiro (2017), em que as duas encontram a conexão entre a construção do silêncio enquanto prática repressiva utilizada pela colonialidade do poder e os sentidos de respeito e explicitação dos lugares de fala nas produções de discurso, apontando que entre o silêncio embutido e o lugar de fala reconhecido existe algo que vou chamar de lugar de escuta.

Neste sentido, a máscara representa o colonialismo como um todo. Ela simboliza políticas sádicas de conquista e dominação e seus regimes brutais de silenciamento dos (as) chamados (as) 'Outros (as)': Quem pode falar? O que acontece quando falamos? E sobre o que podemos falar? (KILOMBA, 2016, p. 172).

Partindo desta compreensão, exerço aqui minha resistência ao falar como quero, inclusive incluindo um agradecimento às pessoas que, durante um percurso formativo, exercitam esse lugar de escuta não condescendente, nem em busca de uma pedagogia de como "lidar" com a "diversidade" como muitos professores acadêmicos fazem, mas com simplicidade, respeito e abertura. Talvez academicamente esse agradecimento não caiba dentro de um ensaio, mas tenho priorizado a honestidade aos sentimentos em detrimento das normas que me dizem o que fazer e como me portar.
Neste ensaio, pretendo escrever um pouco sobre como as leituras, processos de escrita e experienciais de uma disciplina ofertada pelo Departamento de Antropologia ao curso de graduação em Ciências Sociais da Universidade Federal do Rio Grande do Sul ${ }^{55}$, estiveram presentes em meus projetos de pesquisa, em outras disciplinas e auxiliaram (ou não) a delinear meus interesses de pesquisa. Acionarei, no desenrolar das linhas, alguns dos autores indicados no semestre, relacionando-os a outras leituras decoloniais e pós-coloniais feitas durante minha experiência de saber-me mundo ${ }^{56}$ e no mundo, por meio de encontros, físicos ou não, com uma série de intelectuais afro-diaspóricas. As escolhas não são aleatórias; elas estão ligadas justamente às inquietações que perpassaram minha trajetória de estudante de Ciências Sociais no ano de 2017. A partir de perguntas como: de que maneira a alteridade é construída pelas nossas posições e lugares de fala? Como a gente se reinventa e inventa o outro constantemente através da Antropologia? Quais os múltiplos impactos desse processo? Será metodologicamente possível reconhecer esses impactos?

A inventabilidade ${ }^{57}$ da cultura, a experiência de alteridade criativa e trabalhada simultaneamente pelos multiversos ${ }^{58}$ envolvidos no que sejam "trabalhos de campo", as muitas autoridades envolvidas na etnografia da vida, cujo tecido se forja em vínculos por vezes nada normais para o entendimento universalizante que as ciências ocidentais (ou ocidentalizadas?) possuem; estas são sínteses e bonitos jogos de palavras que tentam explicitar aqui as confusões e caminhos que estavam por trás de meu longo silêncio em algumas aulas, ou nos bancos dos ônibus e trens que foram e são parceiros de percursos e de percalços $55 \quad$ Cursei a disciplina de Teorias Antropológicas Contemporâneas, tendo como docente regular o Dr. Jean Segata, e como estagiárias docentes as agora pós-graduadas em Antropologia Social, Alessandra Estevam da Silva, Juana Prieto, Ana Milena Prieto e Elisa Vargas. Minha experiência na disciplina data do segundo semestre de 2017. 56 Para compreender o que quero dizer com isso, indicaria escutar a cançã " "Um corpo no mundo", de Luedji Luna. 57 Aqui me refiro à ideia expressada por Roy Wagner no capítulo "A cultura como criatividade", do livro "A invenção da cultura" (2012). Neste capítulo o autor discute sobre o papel das ambiguidades e mútuas invenções que ocorrem no trabalho de campo e em campo. E, também, como ao mesmo tempo em que se "inventa" constantemente, por meio do trabalho antropológico, a cultura dos sujeitos de pesquisa, estes também estão inventando o seu ser a partir de seus próprios referenciais. Roy Wagner exemplifica o que quer dizer ao contar estudar outra cultura, e chamar isso de "trabalho". Ver página 72 do livro citado.
estasado, estar se dedicando a

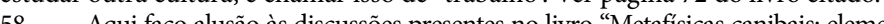

58 Aqui faço alusão às discussões presentes no livro "Metafísicas canibais: elementos para uma antropologia pós-estrutural' (2015), de Eduardo Viveiros de Castro, especialmente as que se referem a construções sociais que, ao meu entender, traduzem um diálogo entre epistemologias e cosmologias nos processos de subjetivaçaó que os olhares antropológicos produzem. Tendo em vista que uma alteridade que possa não ser catalogada como canibal teria que considerar a legitimidade de que existem multiversos, ou seja, múltiplas possibilidades de inteligibilidades de mundos, não a partir
de um conhecimento balizador, mas sim histórica e contextualmente elaborado e não apenas "aceito" ou "legitimado" pelos saberes antropológicos interpretativistas (interpretativos e extrativista) (grifo meu e termo de minha autoria).
a 
de ser uma universitária-trabalhadora-sonhadora que se encanta e se irrita com a Antropologia, sempre, desde que a ela foi apresentada.

\section{As Inquietações Que Me Moveram}

Em 2017, tive algumas oportunidades de desenvolver pesquisas, escrever artigos e me movimentar no sentido dos meus interesses de estudo dentro e fora da universidade. Elaborei um esboço de artigo sobre racismo e desamor ${ }^{59}$, escrevi conjuntamente com companheiras de faculdade e de resistência sobre as ações afirmativas e o processo de akilombamento ${ }^{60}$ da Reitoria no ano anterior ${ }^{61}$, apresentei um projeto de pesquisa ao programa de iniciação científica do Núcleo de Estudos Afro-brasileiros (NEAB/UFRGS) ${ }^{62}$ e iniciei um estágio que se tornou uma tentativa de etnografia na Secretaria de Desenvolvimento Social de São Leopoldo $^{63}$. Talvez não pareça tanto, para quem já está imbricado nesse universo de produção constante dentro da academia, mas para uma aprendiz como eu, foram grandes passos no sentido de organizar maneiras de me comunicar, para além das falas e ensinamentos que me foram apresentados desde os primeiros semestres no curso de Ciências Sociais.

Todos esses espaços estiveram movimentados por inquietações vindas das leituras de aula, especialmente o conceito chave dos encontros posteriores, a saber, as ontologias múltiplas, de Annemarie Mol (1999). Ouso então, como ela, apresentar mais perguntas do que respostas, por entender que um ensaio é, por si só, um

59 Racismo, Memória e Afeto: Situações de Desamor, resumo apresentado no XXIX SIC UFRGS/2017. 60 Escrevo "akilombamento" em respeito às origens do termo, cujo uso do "qu" está atrelado a uma lusografia que esconde a afrikanidade.

61 Trata-se da apresentação oral intitulada "Balanta: nenhum cotista a menos", apresentada no III Copene Sul Congresso Regional de Pesquisadores Negros e Negras. Agradeço a existência das duas companheiras de luta e vida que nos caminhos acadêmicos têm sido sopro de esperança e resistência. Meu obrigado à futura psicóloga Vitória Freitas Cazuane è futura administradora Mariana Pedroso, assim como a todes que ousaram lutar pela educação e os direitos construídos por anos de resistência e articulação do Movimento Negro Brasileiro, em suas mais diferentes esferas. Em memoria e registro do akilombamento da Reitoria da Universidade Federal do Rio Grande do Sul

62 Em 2017, o NEAB UFRGS ofereceu a oportunidade de alunes inscreverem suas ideias de pesquisa para nativas epistemológicas: a interseccionalidade como caminho ou năo. Meu projeto de pesquisa se intitulou "Altertos humanos", com orientacão do Dr Marcus Vinicius Rosa e coorientação da Ms. Alessandra Estevam do Silva63 Estagiei-pesquisei nesta secretaria durante o período de um ano e meio, de setembro de 2017 a março de 2019, com supervisão-orientação do cientista social Paulo Crochemore da Silva, o qual me ensinou e compartilhou comigo o que era o Sistema Unico de Assistência Social, especialmente a área denominsida Vigilância partilhou comigo o que era o Sistema Unico de Assistência Social, especialmente a area denominada Vigilância foi sua primeira experiência como supervisor de um estágio. convite a tentativas e estas nunca nascem prontas. São expressões e performances de múltiplas fontes de saber: nosso corpo, nossas experiências de vida e também das letras articuladas daqueles que temos em folha e tina, ou em caracteres digitais. Este ensaio será organizado em inquietações entrelaçadas, ou seja, cada subtítulo se refere a um determinado processo criativo oriundo do questionamento-título. Não vou me ater em mais explicações, pois deixarei livre para que possíveis leitores deste ensaio compreendam o que sintetizo nestas linhas de apresentação.

\section{Inquietação I: Estará o Outro Fora de Mim?}

Para elaborar este ensaio, voltei a ler meu caderno do semestre que recebeu anotações de vozes minhas e dos demais envolvidos na minha interação com as teorias debatidas. Nas páginas que se referem à leitura do capítulo de "A invenção da cultura” (WAGNER, 2012) indicado no programa, encontrei a seguinte anotação: "Se a etnografia é parte do que Roy Wagner chama de invenção da cultura, sua atividade é plural e além do controle de qualquer indivíduo". Não anotei a autoria do comentário ou citação, mas este trecho dialoga com inquietações sobre o que chamarei aqui de alteridade subjetiva.

Neste mesmo período estava lendo muito sobre interseccionalidade, especialmente nos escritos de Kimberlé Crenshaw (2002), Patricia Hill Collins (2016) e Avta Brah (2006), e isto me fez pensar intensamente sobre as diferentes concepções de deslocar-se. Talvez este tenha sido o verbo que mais se fez experiência em minha vida, neste ano. Deslocamentos no plano das ideias, ao me ver inserida em um mundo que se negava e segue se negando a me ver no papel de investigadora e não de investigada, tornando real a metáfora utilizada por Crenshaw (2002) sobre os cruzamentos que intersectam os âmbitos da vida de mulheres e homens negros no mundo, das mais diferentes maneiras.

O cotidiano universitário em um instituto e um curso considerados questionadores e críticos, quando localizados em um estado orgulhoso de seu machismo e racismo, como é o caso do Rio Grande do Sul, toma outras nuances, principalmente quando as perguntas e críticas aos consagrados conteúdos não partem de futuros Roys Wagners, mas sim de escrevivências de Conceições Evaristo, de Angelas Davis e de Carlas Akotirenes ${ }^{64}$.

64 A intenção aqui é aludir as existências e potências das autoras citadas, ainda que seus trabalhos não 
Do mesmo modo, o ir e vir a São Leopoldo, cidade na qual realizava meu estágio-pesquisa, me fazia recordar quase que linha por linha as ideias de outsider within organizadas pela socióloga Patricia Hill Collins (2006). Um grande ponto de interrogação no meio da sala do setor de Planejamento e Gestão. Era assim que me sentia e me faziam sentir os olhares-corpos desacostumados com cientistas sociais em uma secretaria de Assistência Social. Ainda mais cientistas sociais como eu, com turbantes que me protegiam constantemente o orí e me faziam mais forte perante os racismos explícitos e implícitos vivenciados dentro e fora desta cidade, que se orgulha de ser berço da colonização alemã e justifica posturas racistas com seu orgulho racial branco. Aquele, como qualquer outro lugar do mundo, é meu por direito. Como ser humano e, naquele caso, como cientista social em formação, eu não deveria ser uma fuga do "normal", afinal de contas o edital da vaga era muito claro sobre o perfil e as habilidades necessárias e eu cumpria, como cumpri, com todas elas. O não normativo estava no corpo que ocupava o espaço: um corpo negro, falante sobre o que sabia das coisas práticas sem muitas "papas na língua", e com muita vontade de seguir ocupando os lugares nos quais quisesse estar.

A pluralidade, a multiplicidade e mesmo a concepção de uma mútua invenção entre atores de um determinado contexto de compartilhamento de códigos é discutida em termos externos a uma existência singular interseccional, ou seja, como podemos pensar essa inventabilidade mútua de pesquisador e interlocutor de que trata Roy Wagner (2012), quando a alteridade está intrínseca no sujeito pesquisador? Não se trata aqui somente de atentar aos marcadores sociais do sujeito pesquisador, mas especialmente ao seu processo de significação com o mundo a partir daí.

Exemplifico: embora o discurso contemporâneo desloque a atenção para o papel da subjetividade na Antropologia, ainda perante alguns dos professores e professoras dos cursos de ciências humanas as abordagens que levam a sério isto em suas etnografias são consideradas excessivamente autoantropológicas, por se enxergar demais o pesquisador durante a pesquisa, durante sua imersão em um contexto de mútua inventabilidade cultural.

Expõe-se, assim, um evidente paradoxo que distancia a formação dos estudantes de Ciências Sociais do debate antropológico contemporâneo, ao mesmo tempo em que traz à tona os constantes jogos de legitimidade científica, nos quais tenham sido diretamente citados neste trabalho, são referências pessoais, políticas e intelectuais da autora do presente ensaio. considerar a importância fundante da reflexividade não é suficiente para que a mesma seja verdadeiramente adotada como caminho discursivo mais próximo de uma Antropologia autocrítica, tal como se apresenta durante as discussões em sala de aula.

Durante o capítulo que lemos, intitulado "A cultura como criatividade" (WAGNER, 2012), nos foi apresentado que as concepções de cultura tiveram muitas modificações ao longo do tempo e que isto reflete também a mútua ação de subjetivação e construção de subjetividades através da linguagem. Mas de que adianta dizer que somos mutuamente criados, se no fim das contas somos forçados, pela estrutura de produção científica, a retomar nossos arcaicos papéis de pesquisador e pesquisado?

Inquietação II: O Que Me Faz Estar Antropóloga: a Etnografia ou as Inflexões da Alteridade?

A disciplina de Teorias Antropológicas Contemporâneas me ensinou, entre outras coisas que, se é possível discutir linhas gerais de abordagens na Antropologia atualmente, é questionando quais/quem são os atores que tem sido "sujeitos" deste campo do conhecimento, a partir da ideia de que as relações, vínculos, espaços ${ }^{65}$ tomem um lugar tão importante quanto a discussão de quem tem mais ou menos agência na (re)invenção constante das concepções de cultura.

Nesse sentido, a leitura de Marilyn Strathern (2014) discutindo os limites de uma autoantropologia foi o disparador desta segunda inquietação que desenvolvo. Dos aprendizados e dos constantes embates que movimentam essa caminhada de graduar-me em Ciências Sociais, parece latente que o que busco é justamente ser uma antropóloga que consiga lidar com a autoantropologia que a alteridade branca, masculina, heteronormativa do meio universitário impõe ao meu caminho.

Não vejo como fugir de pensar essa mútua sensação de familiaridade e de distanciamento que perpassam as minhas incursões, sendo muitas vezes incompreendida em meus questionamentos pelo simples fato de ser ouvida pela minha identidade, e não pelo que estou perguntando. São incontáveis as vezes em que fiz um questionamento de fundo sobre a matéria em sala de aula e fui respondida sobre os aspectos que tangem a discussão racial, quando esse não era meu interesse no momento. E aqui Alberto Guerreiro Ramos (1995) é certeiro ao tratar do quanto nós,

$\overline{65}$ Entendendo aqui espaço como uma localização imagética tracejada pelos percursos que formam os encontros. 
pessoas negras, estamos subjetivadas como "objetos" de pesquisa da Sociologia no imaginário dos cientistas sociais, enquanto o outro inquestionável, e aquele que está na posição de ser interpretado pela teoria social eurocêntrica e formulada desde um modelo de humanidade na qual o branco cisgênero heterossexual é o padrão.

Superar o olhar de negro tema (RAMOS,1995) direcionado a nós, futuros cientistas sociais, antropólogas/os, sociólogas/os e cientistas políticas/os negros/ as/es é uma tarefa urgente que não se realiza somente com a nossa presença nos espaços acadêmicos e outros onde atuamos nesta profissão, mas por meio de uma desconstrução desse olhar racista que define qual o nosso lugar nas teorias e práticas sociais. Marilyn Strathern (2014) trata sobre como a autoantropologia no debate é falar do extremo da aproximação, um exercício de alteridade desde si mesmo. Permito-me complementar, afirmando que o efeito etnográfico está em se ver nesse processo de ser criado e recriado, desde o outro para si e em si, transformando em trabalho etnográfico a experiência complexa da subjetivação implícita no verbo ser: ser pesquisador da alteridade, ser a alteridade implícita e criar uma interpretativa forma de dizer o outro, para este e para si mesmo, levando em consideração as prévias imagens que temos de quem tem "cara" de pesquisador (a) ou não.

|nquietação ||l!: Existe Espaço para Conclusões Entre Multiversos Criativos?

A ampliação do espectro deleitores (e também feitores) da pesquisa etnográfica traz para a cena o deslocamento constante de qualquer estabilização de quem faz e quem é feito pela Antropologia, conduzindo a pensarmos a própria Antropologia como relação móvel e relativa. Não mero relativismo, mas oscilação de experiência, novidade, o novo do instante seguinte, no qual os protagonistas e os coadjuvantes da montagem etnográfica oscilam ao sabor da vida, que move e é movida pela caneta que transfere aos registros de campo as tintas das alteridades criativas.

Ensaiando a licença poética, aprendida com as contribuições de Tim Ingold ${ }^{66}$, de contar esse tecido a partir do qual a vida emerge e é constituída, espero não cair novamente naquele probleminha de quem pode ou não ser poético na universidade. Será que se eu fosse Tim Ingold, com toda a minha pessoalidade de um corpo negro, feminino cisgênero e lésbico, e falasse assim, tão suavemente, $66 \quad$ Me refiro aqui as ideias de teias da vida, contadas de forma científico poéticas em trabalhos do citado autor. sobre os emaranhados multiversos que nos imbricam nessa cadeia de relações, não seria mais brutalmente questionada sobre o que estava querendo dizer? Quantos anos e quais os pressupostos para que um dia eu possa ser uma Viveiros de Castro e falar de metafísica canibal? Haverá tempo para uma antropóloga, por demais autoantropológica, para isso?

Apenas reflexões inquietantes que me fazem pulsar de medo e vontade, concomitantemente. Eis aí uma sensação advinda da imersão na reflexividade, sentir medo e vontade ao mesmo tempo, com altos índices de cortisona me fazendo escrever o que não digo por medo de ser interpelada por alguma argumentação (in)coerente e complacente com a jovem aspirante à cientista social. Como disse Lélia Gonzalez (1983) em "Racismo e Sexismo na Cultura Brasileira", os lugares sociais da mulher negra em nossa sociedade - e ousaria dizer em muitas outras sociedades da Améfrica Ladina (GONZALEZ, 1988) - foram os de mulata, mãe preta e doméstica. E, no que considero um forte diálogo atemporal com Patricia Hill Collins (2016), estes mesmos lugares fizeram com que muitas de nós, mulheres negras, aprendêssemos a viver na condição de forasteira de dentro. A oralidade e a dororidade (PIEDADE, 2017) que nos une fez com que, mesmo sem ter vivido determinadas dores, eu tenha acessado desde cedo, pela voz de minha mãe $e^{67}$, muitas nuances perversas disfarçadas de portas abertas para manter mulheres incríveis como ela em uma redoma de falsa amizade, matando oportunidades de expansão e realização de autonomias, através da construção de sororidades unilaterais por parte de mulheres brancas ricas, como as "patroas" de minha mãe, na década de 1970. As estratégias da Casa Grande seguem se reinventando. Mas o subtítulo dessa inquietação é uma dúvida: existe espaço para conclusões entre multiversos criativos? Está aqui uma tentativa de conclusão peculiar: conclusão com portas abertas.

James Clifford (2002) nos ensina que existem distintos tipos de autoridade etnográfica: o interpretativo, o experiencial, o dialógico e o polifônico. Eduardo Viveiros

$67 \quad$ Vera Lúcia Costa de Moura, gaúcha de Bagé, no interior do Rio Grande do Sul. Filha mais velha da família dos Costa de Moura. Fez-me presente em um tempo onde eu não existia, pela sua extrema habilidade de contar suas historias de vida para mim. Estimulou-me, talvez sem saber, a querer continuar nessas contações de história que explicitam dores, amores, aprendizados e vidas. Fiz-me aprendiz de cientista social focada em Antropologia, entre outras causas, pelo seu tino investigativo e sua extrema sagacidade. Minha mãe faleceu em julho de 2018, com 66 anos, tendo trabalhado durante toda sua juventude e parte da infância em "casas de família", em que muitas vezes teve que resistir a tentativas de estupro, humilhaçoes racis
que se diziam suas amigas quando precisavam de alguém para curar suas feridas. 
de Castro (2015) nos convida a pensar um perspectivismo não tradicionalmente ocidentalizado, em que não há múltiplos pontos de vista de um mesmo mundo, mas sim que cada perspectiva cria mundos distintos, com similaridades, aproximações, paralelos e possíveis inteligibilidades com diferentes processos de entendimento do que é mundo, mas sempre outros, novos mundos, multiversos olhares originados dos multiversos que são os seres. Quando ouvi que "humano é o nome de uma relação e não de uma substância” e pude experimentar olhar para uma flor em um potinho de água e entender que isso não era a essência do que eu estava vendo, mas sim uma das muitas inteligibilidades possíveis para aquela representação, admito que houve um insight e viajei em um mar de pensamentos em que tudo fez sentido e desfez sentidos em mim. Voltei às ontologias múltiplas e ali elas se sintetizaram. Obviamente, sei que existem muitas distâncias entre Annemarie Mol (1999) e Eduardo Viveiros de Castro (2015), mas em um exercício de análise dos porquês de termos esse desenho de programa para a disciplina, este foi o momento em que os vínculos se fizeram em mim, esse "eu" tão multiversificado. Enfim entendi, de algum modo, que existe uma intensidade e uma velocidade na alteridade. Ela não é conceito efêmero e "excessivamente abstrato", ela é epistemologicamente densa, ontologicamente feroz, pelo menos na minha vida. Você já se perguntou sobre o impacto dela na sua vida? É, você mesmo, que está lendo este ensaio e talvez pensando: "Vixe, pirou de vez a guria!”. Mas que seja, se pirei mesmo, espero que essa piração tenha incomodado você, te convidado a se ver aqui, se pensar parte dessas letras que preenchem lentamente esse virtual papel onde despejo meu primeiro ensaio, bem assim, dessa maneira preocupadamente despreocupada, esperando que, antes de qualquer coisa, seja lido e atinja alguém com essas pegadas em forma de elemento do alfabeto, fingindo ser um trabalho da faculdade, quando na verdade é um convite a outras trocas onde elas se tornem mudança crítica e atenta.

\section{Referências}

BRAH, Avtar. Diferença, diversidade, diferenciação. Cadernos Pagu, Campinas, v. 26, p. 329-376, jan./ jun., 2006.

CASTRO, Eduardo Viveiros de. Metafísicas canibais: elementos para uma antropologia pósestrutural. São Paulo: Cosac Naify, 2015.

COLLINS, Patricia Hill. Aprendendo com a outsider within: a significação sociológica do pensamento feminista negro. Sociedade e Estado, Brasília, v. 31, n.1, p. 99-127, 2016.
CLIFFORD, James. "Sobre a autoridade etnográfica"; "Sobre a alegoria etnográfica". In: A experiência etnográfica: antropologia e literatura no século XX. Rio de Janeiro: Editora UFRJ, 2002, p. 17-99.

CRENSHAW, Kimberlé. Documento para o encontro de especialistas em aspectos da discriminação racial relativas ao gênero. Estudos Feministas, Florianópolis, n. 10, p. 171-188, 2002.

GONZÁLEZ, Lélia. A categoria político-cultural de Amefricanidade. Tempo Brasileiro, Rio de Janeiro, n. 92/93, p. 69-82, jan./jun., 1988.

GONZALEZ, Lélia. Racismo e sexismo na cultura brasileira. In: SILVA, L. A. et al. Movimentos sociais urbanos, minorias e outros estudos. Ciências Sociais Hoje, Brasília, ANPOCS, n. 2, p. 223-244, 1983.

KILOMBA, Grada. A máscara. Tradução de Jessica Oliveira de Jesus. Cadernos de Literatura e Tradução, São Paulo, n.16, p.171-180, 2016.

LUNA, Luedji. Um corpo no mundo. Disponível em: $<$ https://www.youtube.com/watch?v=VG7LC6QzTA>. Acesso em: 11 jun. 2019.

MOL, Annemarie. Política Ontológica. Algumas ideias e várias perguntas. In: NUNES, João Arriscado e ROQUE, Ricardo (org.) (2007). Objectos impuros. Experiências em estudos sociais da ciência. Tradução de Gonçalo Praça. Porto: Edições Afrontamento.

PIEDADE, Vilma. Dororidade. São Paulo: Nós, 2017.

RAMOS, Guerreiro. Patologia Social do Branco Brasil. In: Introdução crítica à Sociologia Brasileira. Rio de Janeiro: Editora UFRJ, pp. 215-240, 1995.

RIBEIRO, Djamila. O que é lugar de fala? Belo Horizonte: Letramento, 2017.

RODRIGUES, Aline de Moura. Racismo, Memória e Afeto: Situações de Desamor. In: Salão de Iniciação Científica UFRGS, 29., out. 16-20, 2017, Porto Alegre. Resumos... Porto Alegre, RS: UFRGS, 2017. Disponível em: <http://hdl.handle.net/10183/176923>. Acesso em: 11 jun. 2019.

STRATHERN, Marilyn. O efeito etnográfico e outros ensaios. São Paulo: Cosac Naify, 2014.

WAGNER, Roy. A cultura como criatividade. In: WAGNER, Roy. A invenção da cultura. São Paulo: Cosac Naify, 2012. 
ESCREVIVÊNCIAS SOBRE CUIDADO AO USUÁRIO DE ÁLCOOL E OUTRAS DROGAS: DIÁLOGOS ENTRE REDUÇÃO DE DANOS E PENSAMENTO DESCOLONIAL

Marina Tremper Míriam Cristiane Alves Károl Veiga Cabral

Este texto é fruto de um trabalho de final do curso de Psicologia da Universidade Federal de Pelotas (UFPel), desenvolvido pela acadêmica e acompanhado pelas orientadoras. O tema, cuidado em saúde mental do usuário de álcool e outras drogas, emerge das vivências, experiências e encontros das autoras com os cenários da saúde coletiva. As experiências aqui apresentadas foram produzidas em ambientes acadêmicos, sobretudo por meio de estágios obrigatórios realizados em um Centro de Atenção Psicossocial Álcool e Drogas (CAPS-AD), em um serviço de Redução de Danos, e na Atenção Básica com equipes multiprofissionais de uma Unidade Básica de Saúde (UBS), em um município do interior do estado do Rio Grande do Sul.

Encontros de saberes e indagações entre a universidade e o território, entre professoras e aluna, entre sujeitos que compartilham serviços de saúde e espaços da cidade. Encontros recheados de singularidades a partir das quais buscamos produzir o múltiplo no tocante às possibilidades de existir e (re)existir no tecido social. No entanto, circular por diferentes territórios de saberes, se implicar com o saber de cada sujeito que circula pelo tecido social, exigiu-nos a compreensão de que esta circulação não é igual e nem parte do mesmo lugar para cada um desses sujeitos. Afinal, o espaço é dividido pelo humano, como nos aponta Milton Santos (2003), e as cidades estão cheias de obstáculos e fronteiras visíveis e invisíveis à circulação de alguns/algumas.

Eis a presença da classificação social imposta pela colonialidade do poder que hierarquiza o humano e dita o lugar que cada um deve ocupar, ou seja, que atua na diferenciação da população do mundo entre superiores e inferiores, irracionais e racionais, primitivos e civilizados (QUIJANO,1991), entre humano e não humano (FANON, 2008), entre quem tem o direito à vida e quem não tem (MBEMBE, 2016). Hierarquização do humano que impõe diferentes modos de (re)existir. (Re)existir na perspectiva de atualização e reinvenção da própria existência diante da lógica colonial, diante de todo o processo de dominação, exploração e subalternação impostos pela colonialidade (ALVES; AMARAL, 2018). (Re)existir no sentido de reinventar-se na "subversão à colonialidade para abrir fissuras e descolonizar os muros físicos e subjetivos que nos aprisionam" (CLASEN; ALVES, 2019, p.129). (Re)existência que nos impulsiona e nos constitui enquanto sujeitos (AMARO; ALVES; MOLON, 2019).

E o que tudo isso tem a ver com a saúde?

Para atuar no cuidado em saúde é preciso criar o que denominamos de um espaço de compreensibilidade mútua entre vivências, experiências e saberes diferentes que se encontram nos territórios, no tecido social. Um espaço onde os múltiplos caminhos e andanças que cada sujeito produz devem ser respeitados e valorizados; onde possamos falar e nos escutar em nossas necessidades e em nossas possibilidades de existir; onde o caminhar juntos/as, lado a lado, é fundamental para produzir vida, (re)existências. Porém, nem sempre este espaço de compreensibilidade mútua é produzido nos serviços de saúde mental.

Diante do entusiasmo de uma acadêmica de Psicologia que estava vivenciando o cuidado em saúde mental em um serviço da Rede de Atenção Psicossocial (RAPS), sentíamos, ao mesmo tempo, um aperto engasgado frente a experiências que se distanciavam dessa ideia de compreensibilidade mútua.

O incômodo foi sentido durante observações e acompanhamentos dos acolhimentos do CAPS-AD, onde muitos usuários que ali chegavam por meio de encaminhamentos da rede pareciam distantes dos motivos que os fizeram buscar atendimento em saúde mental, e perdidos em relação às possibilidades de cuidado. Assim como outros mostravam-se incomodados. Das narrativas, em sua maioria de homens brancos e negros, emergiam histórias sobre o consumo de drogas, violências e experiências angustiantes com internações em hospitais psiquiátricos, ouvidas, geralmente, com certa naturalidade pelos profissionais.

O CAPS-AD tinha a possibilidade de permanência noturna e era o único da cidade nessa modalidade. Entretanto, o atendimento noturno era disponibilizado somente para usuários que estivessem abstinentes, sem ideação suicida ou alucinações auditivas e/ou visuais. Essa informação nos causava estranhamento, embora compreendêssemos que existia uma carência de recursos físicos e materiais para acolher determinadas demandas. Afinal, se o CAPS$\mathrm{AD}$ não podia acolher todos os usuários, para onde iriam aqueles que não se encaixavam nos critérios estabelecidos? 
Esta escrevivência tem a intenção de falar de encontros e desencontros na busca por esse espaço de compreensibilidade mútua vivido na relação com usuários de álcool e outras drogas a partir da experiência acadêmica em um curso de Psicologia. José é o usuário guia que nos leva a percorrer diferentes territórios. E no caminhar juntos, nos leva a indagar o pensamento colonial que ainda captura nossos modos de cuidado no campo da Psicologia. Imerso no uso de álcool e outras drogas, José explicita a fragilidade de nossas relações com o trabalho e o cuidado em saúde mental coletiva, com os problemas familiares oriundos da falta de políticas públicas, com as vulnerabilidades em que vivem os Josés da vida.

José nos desacomoda, aguçando nossa escuta e nosso olhar para percebermos em que sociedade vivemos e em que sociedade queremos viver. Desacomodar que nos exige um posicionamento quanto aos modos de cuidar no campo da saúde coletiva, em especial, da saúde mental para usuários de álcool e outras drogas. Desacomodação, portanto, que nos leva à Redução de Danos como diretriz ética do cuidado para muitos Josés.

Afirmar o uso da Redução de Danos é tomar uma posição de defesa da vida, em um cenário de transformações nas políticas públicas de álcool e outras drogas que atravessamos, neste momento histórico, de declarada guerra às drogas, de aposta única na abstinência e na internação como formas de tratamento que acabam por produzir vítimas no lado mais frágil desta disputa que é justamente o dos usuários. Defesa esta, que anda na contramão do discurso vigente e, portanto, pretende deslocar olhares, escutas e fazeres numa perspectiva crítica descolonial.

O estudo objetiva problematizar e refletir sobre práticas de cuidado em saúde mental que envolvem os usuários de álcool e drogas. Desafiamo-nos a refletir sobre a colonialidade do poder (QUIJANO, 1991) e do ser (MALDONADO-TORRES, 2007) com a ajuda dos Josés que diariamente atravessam nossos caminhos.

O texto está organizado em cinco seções. Na primeira, levantaremos algumas pistas sobre o campo da saúde mental, sua construção enquanto política pública. $\mathrm{Na}$ segunda, trataremos do percurso metodológico. $\mathrm{Na}$ terceira, salientamos a necessidade de falarmos sobre drogas na atenção básica e em diálogo com a Redução de Danos. E na quarta, colocaremos em diálogo o Pensamento crítico descolonial e a Redução de Danos, além de lançarmos algumas considerações e novos questionamentos sobre o tema do estudo.
Algumas Pistas sobre o Campo da Saúde Mental

Historicamente, a atenção básica se manteve apartada do cuidado em saúde mental devido ao modelo hospitalocêntrico manicomial ofertado no país (CABRAL; SIMONI; FAGUNDES, 2019). O acúmulo produzido no campo da saúde mental coletiva no que tange à construção de modelos substitutivos ao hospitalocêntrico e manicomial como, por exemplo, a Portaria $n^{\circ} 224 / 1992$ e a Portaria $n^{\circ} 336 / 2002$ que normatizam o atendimento em saúde mental no SUS através dos CAPS, e, fundamentalmente, a Lei Federal $n^{\circ} 10.216 / 01$ e a Lei Estadual n 9716/1992, irá tensionar a atenção básica a comprometer-se com o acolhimento e a oferta de cuidado em saúde mental no território.

Este referido acúmulo também desencadeou a definição e construção da RAPS pela Portaria $n^{\circ} 3.088 / 11$, que se constituiu como uma importante estratégia de articulação dos serviços de saúde mental coletiva. Não obstante, em 2017 vivenciamos um retrocesso na Política de Saúde Mental com a publicação da Portaria no 3.588/17 que altera a abrangência da RAPS, transferindo recursos financeiros para as Comunidades Terapêuticas e consolidando-as como foco do cuidado em saúde mental (BRASIL, 2017).

Um dos grandes problemas desta alteração é fazer uma aposta única no modelo da internação e da abstinência como forma de tratamento aos usuários de álcool e outras drogas. Modelo este já testado e que fracassou na maioria dos lugares em que esteve em vigor, inclusive no Brasil (ARAÚJO, 2014). Eis a constatação da necessidade de alterar o modelo e de investir na construção de linhas de cuidado e trabalho em rede. A Rede de Atenção à Saúde (RAS), por meio da Portaria $n^{\circ} 4.279 / 10$, estabelece diretrizes para a organização das redes, como estratégia para superar a fragmentação da atenção e da gestão e aperfeiçoar o funcionamento político-institucional dos serviços de saúde.

Um longo caminho, portanto, foi percorrido para que as pautas de saúde mental ultrapassassem os muros de hospitais psiquiátricos. A questão sobre consumo de drogas não foi diferente. Entre cenários de avanços e retrocessos, a luta dos movimentos sociais em impulsionar a mobilidade em direção a políticas públicas democráticas e abandonar métodos desumanos e repressivos foi conduzindo tais conquistas. Como política e planos de ações nos níveis de saúde do país, em 2001 
foi inserida a Política de Atenção Integral ao Usuário de Álcool e Outras Drogas, através da Lei Federal no ${ }^{\circ}$ 10.216/200168 (SANTOS; FERLA, 2017). Mesmo antes de sua promulgação pelo Estado, esta Lei inaugurou uma nova perspectiva de cuidado sobre o usuário de drogas, ficando conhecida como Lei Antimanicomial, por se concentrar na reabilitação e reinserção social (BRASIL, 2003).

A Política de Atenção Integral ao Usuário de Álcool e Outras Drogas estabelece a atenção básica não somente como responsável pela porta de entrada, mas também pela condução e mediação do percurso dos sujeitos pelos demais serviços de saúde (BRASIL, 2003). O cuidado preconizado nessa política não deve ser orientado por um modelo asilar e com referência hospitalar, mas por propostas descentralizadas que relativizem práticas universais e a-históricas (LIMA; DIMENSTEIN, 2018).

Ao longo desta trajetória existem muitas lacunas entre os caminhos sugeridos pelas políticas públicas sobre drogas e o cuidado que os profissionais conseguem estruturar e oferecer nos serviços de saúde. $\mathrm{E}$ as diretrizes que guiam o cuidado ao usuário de álcool e drogas não são suficientes para orientar os profissionais a realizarem o acolhimento desses sujeitos. Tais dificuldades no manejo da demanda por parte das equipes acabam incitando encaminhamentos precipitados. Diante deste contexto, interroga-se: Onde será que esses caminhos se desencontram? De que forma essa prática produz efeitos na continuidade do tratamento e no vínculo do usuário com o serviço? Estariam os profissionais silenciando os sofrimentos produzidos pelas questões de álcool e drogas, esquivando-se da responsabilidade em consolidar o cuidado integral? De que forma os serviços de saúde vêm contribuindo para a exclusão e marginalização dessa população?

A partir de reflexões e questionamentos sobre o cuidado em saúde mental com usuários de álcool e outras drogas e da premissa sobre a necessidade de construção de um espaço de compreensibilidade mútua entre trabalhadores e usuários, entendemos a Redução de Danos como uma potencialidade para a produção coletiva do cuidado em saúde, envolvendo diversos agentes da rede, e sobretudo apostando na autonomia dos sujeitos, especialmente no que tange ao desenho do seu projeto de vida. A aposta é 68 A Lei Federal n $\mathrm{n}^{\circ} 10.216 / 2001$ continua em vigor, entretanto, houve alterações em portarias e normativas relativas ao uso de drogas. A Lei Federal n ${ }^{0} 13.840 / 2019$, instituída em 5 de junho de 2019, redirecionou os re-
cursos financeiros, antes enderecados à RAPS, para as Comunidades Terapêuticas, retirando do texto a política cursos financeiros, antes endereçados à RAPS, para as Comunidades Terapêuticas, retirando do texto a política
de redução de danos e voltando a colocar a abstinência como única meta no tratamento de usuários de álcool de redução de danos e voltando a colocar a abstinência como única meta no tratamento de usuários de álcool e outras drogas. Tal medida implica um redirecionamento da atenção à saúde preconizada, até então como um como refere Martínez-Hernáez (2008). na atenção básica como um potente espaço para desenvolver e legitimar as estratégias de Redução de Danos ofertando cuidado no território independente do uso.

O Percurso Metodológico

A construção teórico-metodológica busca visibilizar experiências e saberes contra-hegemônicos, na perspectiva de provocar práticas de cuidado em saúde mental coletiva desencadeadoras de movimentos de (re)exististências, propondo um lugar de escuta e fala que pressupõe a compreensibilidade mútua entre sujeitos.

Cabe situar que o estudo foi possível por meio das experiências vividas no projeto de extensão intitulado "Saúde Mental na Atenção Básica: uma clínica ampliada em saúde coletiva", do curso de Psicologia da UFPel. Este projeto, por sua vez, encontrase vinculado a um projeto de pesquisa do Núcleo de Estudos e Pesquisas ÉLÉÉKO, nomeado "A Violência do Inexistir: a construção de uma Clínica Política De(s)colonial".

No percurso metodológico, e inspiradas na Redução de Danos, que se constitui na subversão à lógica manicomial de atenção à saúde de usuários de álcool e drogas, assumimos como postura ético-política o movimento de colocar em pauta a descolonização do método de pesquisa. Deste modo, o caminho aqui percorrido partiu de palavras e histórias remontadas a partir da memória de quem aqui compartilha narrativas contadas, vividas e sentidas ao longo de estágios curriculares e orientações acadêmicas em Psicologia, no campo da saúde mental coletiva. Apostamos no conteúdo vivencial e experiencial expresso por nossas memórias, enquanto elemento fundamental para a discussão teórica e metodológica aqui apresentada.

Nesse sentido, lançamos mão da escrevivência, como uma metodologia de escrita negra e brasileira, cujo conceito é trabalhado por Conceição Evaristo (2016) no livro "Insubmissas Lágrimas de Mulheres", com o intuito de traçar histórias que por muito tempo permaneceram esquecidas e invisibilizadas pela literatura brasileira, assim como pela ciência. Por meio da sua escrevivência, Evaristo expressa a voz, sentimentos, dores, alegrias, gritos e sussurros de uma população que teve seus processos de existências silenciados ao longo da história do país, especialmente as mulheres negras (SOUZA, 2018).

Nessa perspectiva os sujeitos aqui escrevividos são os usuários de álcool e drogas cujos encontros foram provocados pelos serviços de saúde. Encontros 
e experiências singulares e, ao mesmo tempo, coletivas, isto é, conforme Lívia Maria de Souza (2018), agenciamentos coletivos, processos que fazem sentido para quem compartilha experiências semelhantes no mundo. Assim, construímos diálogos com um José único e múltiplo a um só tempo.

Histórias e narrativas de um José, que podem ser ou não reais, mas que existem, pois, como assevera Conceição Evaristo (2014, p.14), o "mundo que é dito existe". A autora usa de um caminho transmitido no sentido de buscar outras palavras para não correr o risco de ficar presa a uma linguagem dada que pode silenciar e depreciar outras histórias. Como afirma Evaristo (2017) ${ }^{69}$ : "Nossas conversas são como colchas de retalhos. Nossa escrevivência não pode ser lida como história de ninar os da casa-grande, e sim para incomodá-los em seus sonos injustos".

Portanto, este estudo tem como disparador as vivências, experiências, os afetos e as desacomodações no contexto da saúde coletiva, em diálogo constante com um José. A aposta na escrita sobre as experiências do cotidiano e na reflexão sobre um olhar mais acolhedor e humano aos usuários de álcool e outras drogas busca dar vazão às narrativas ouvidas e vividas, a partir do campo acadêmico, em estágios curriculares de um curso de Psicologia, para que possam chegar e ecoar em diferentes sujeitos, na esperança de transformação de práticas de cuidado em saúde mental coletiva.

Precisamos Falar sobre Drogas: Atenção Básica e Redução de Danos Produzindo Cuidado em Saúde Mental Coletiva

Permita que eu fale, não as minhas cicatrizes

Elas são coadjuvantes, não, melhor, figurantes

Que nem devia tá aqui

Permita que eu fale, não as minhas cicatrizes

Tanta dor rouba nossa voz, sabe o que resta de nós?

Alvos passeando por aí

Permita que eu fale, não as minhas cicatrizes

Se isso é sobre vivência, me resumir à sobrevivência

É roubar o pouco de bom que vivi

(EMICIDA, 2019)

69 Transcrição livre da entrevista de Conceição apresentada no programa Estação Plural da TV Brasil, em 12 de junho de 2017. Um dos temas abordados foi 'escrevivência e maturidade'. Disponível em: https://www. youtube.com/watch?v=Xn2gj1hGsoo. Acesso em: 20 mai. 2019.
A saúde foi se constituindo como um campo socialmente determinado, dentro do qual a figura do médico se tornou centralizada e hegemônica (MERHY,2002). Campo cujas práticas, por parte dos profissionais, são atravessadas por discursos reducionistas e estigmatizantes, gerando uma incapacidade de lidar com a complexidade do fenômeno sobre as drogas (GONDINHO et al, 2018). Discursos que discriminam e potencializam a lacuna assistencial em relação aos usuários de álcool e outras drogas, que por sua vez, já está constituída por barreiras de acesso impulsionadas pela dificuldade de acolhimento e pela reprodução dos modelos que priorizam os encaminhamentos aos serviços especializados (COSTA; RONZATI; COLUGNATI, 2017).

Discursos e práticas que impõem aos usuários de álcool e outras drogas diferentes tipos de violências, sejam elas, psíquica, física e/ou racista, em diversos cenários, espaços e territórios do tecido social. O verso de Leoni, em Primavera Fascista (2018) nos dá algumas pistas:

$$
\begin{aligned}
& \text { Cê jura } \\
& \text { Que a viatura me enquadra porque eu sou suspeito } \\
& \text { Tortura é o que fazem comigo dentro dos becos } \\
& \text { A essa altura é o diabo no divã } \\
& 4 \text { horas da manhã e a polícia injuriando mais um preto } \\
& \text { Porra cês são racistas, cês são fascistas (LEONI, 2018) }
\end{aligned}
$$

Como parte integrante do tecido social, no campo da saúde estamos emaranhados/as por uma concepção proibicionista e punitivista do uso de drogas, produzindo efeitos sobre o cuidado ou o não cuidado em saúde. Será esse o motivo pelo qual, muitas vezes, as capacitações sobre a temática da saúde mental e o uso de álcool e outras drogas não modifiquem, tampouco abram fissuras, nas práticas de cuidado dos profissionais? Afinal, temos um percurso histórico de criminalização do uso de drogas em nosso país.

A primeira Lei sobre drogas no Brasil, Lei no 6.368/1976, foi constituída a partir de uma exigência da elite burguesa brasileira, e sob a justificativa de implementação de medidas a favor da "guerra contra as drogas", imprimindo, deste modo, ações discriminatórias e racistas contra negros e pobres nas favelas (SIQUEIRA, 2010, p.65). A guerra contra as drogas alimenta políticas de repressão contra grupos específicos, em especial a população negra (LABATE et al, 2008). 
Portanto, o cuidado em saúde aos usuários de álcool e outras drogas está carregado de construções moralizantes pautadas no disciplinamento usado como castigo, criminalização do uso da droga, no desrespeito aos direitos humanos e liberdade individual, no silenciamento e encarceramento (PETUCO, 2010).

José nos conduz, por meio de sua experiência, a refletirmos sobre esse cuidado ou não cuidado. Ele chegou ao serviço de Psicologia da UBS encaminhado pelo médico que havia lhe atendido, no dia anterior, com queixa de depressão grave e ideação suicida. José, senhor branco de meia idade e morador da periferia, foi contando sua história conforme se sentia à vontade e seguro. Colocamos à disposição de José uma escuta clínica atenta e sensível. "Lugar de fala” (RIBEIRO, 2017, p. 64) para José, lugar de escuta para estagiária e professoras orientadoras. Conforme Djamila Ribeiro (2017, p. 64), “o falar não se restringe ao ato de emitir palavras, mas de poder existir". Eis um deslocamento conceitual que compreendemos ser fundamental para a escuta clínica.

José realizava tratamento medicamentoso para depressão há mais de 20 anos. Época em que parou de beber porque sua primeira filha estava a caminho. Desde então, ele manteve um consumo não abusivo de álcool. Dizia que se dedicou a buscar a abstinência ao longo desses anos devido à responsabilidade em sustentar a família e ao vínculo construído com a igreja. Por 20 anos, portanto, sua existência esteve pautada na existência da filha, da família e da igreja.

José narra que tinha uma vida tranquila e estável. Com o passar dos anos, sua situação financeira, familiar e seu histórico de saúde física não lhe traziam mais alívio e amparo. Segundo a médica da UBS, não havia perspectivas de melhora para seu diagnóstico clínico. Ele tinha um quadro irreversível de inflamação no ombro e complicações na coluna vertebral. Sua doença física lhe causava dores terríveis no corpo, prejudicando sua relação com o trabalho de pedreiro. José voltou a beber quando sua angústia e tristeza não cabiam mais dentro deste corpo adoecido. Angústia de carregar um corpo que não reconhecia, que não suportava, que não servia para mais nada. Tristeza por perceber o distanciamento e a insensibilidade da família. Sentia-se desvalorizado, sem perspectiva, sem lugar no mundo. Sem lugar na sua própria casa.

Ele realizava acompanhamento com o serviço de Fisioterapia pela RAS, mas como iria melhorar? O fisioterapeuta indicava descanso e repouso após as sessões.
Mas José saía do atendimento direto para o trabalho de pedreiro. Seu trabalho exigia um grande esforço físico; esforço que seu corpo não conseguia mais sustentar. Entre a raiva e o desânimo, a torturante espera da aposentadoria ou do auxílio doença, sua espera se estendia cada vez que recebia mais um indeferimento da justiça. Foi encaminhado para o CAPS/AD pelo médico da UBS, quando mencionou a sua recaída pela bebida. Apesar de estar sendo acompanhado pelo serviço de Psicologia, não houve contato do profissional médico com esta, para articular e discutir o encaminhamento do paciente. Sobre as dificuldades que geram revolta em quem aguarda por questões judiciais, LK, em Poetas no Topo 3.2, diz:

\section{O mundo infestado com o mal}

E eu tô buscando igualdade

Mas no Brasil justiça são papéis de confete no carnaval

Corpo fechado e a mente aberta, primo

Dou mais um trago e nego as dores pra me manter vivo (LK, 2017)

Nós estávamos lá na UBS, no serviço de Psicologia, acompanhando José, buscando criar um espaço de compreensibilidade mútua entre nossos lugares de fala, mas mesmo assim a sensação foi de que o cuidado nos escapou, afinal, a rede falhou com José. Foi o médico que não dialogou com a estagiária de Psicologia, foi a UBS que não dialogou com o CAPS-AD, foi o benefício que não foi concedido, foi o José que ficou no caminho. Foi a falta de uma rede articulada para dar conta das reais demandas de José.

Que peça estaria faltando nessa trama? Que dispositivo poderia ser acionado? Que ingrediente poderia dar um outro sabor a esses encontros e desencontros? São muitos os desafios impostos quando falamos de escuta clínica em saúde mental para usuários de álcool e outras drogas na atenção básica.

O cenário da saúde brasileira demonstra uma cultura de individualização e desconsideração das questões psíquicas e socioculturais, resultando na transferência de responsabilidades fomentada pelos encaminhamentos (VARELA et al, 2016). A insuficiente qualificação profissional na atenção básica em relação à saúde mental é um fator que intensifica a prática dos encaminhamentos, sem responsabilidade com a construção de um plano de cuidado no território, tornando o serviço inacessível ao reproduzir uma lógica estigmatizadora (CORTES et al, 
2014). Assim, a rede de cuidados se mantém desarticulada e ineficaz, desprovida de dispositivos de ação e atenção (PASSOS, 2010).

José não aderiu ${ }^{70}$ ao tratamento no CAPS/AD, pois não entendia o motivo de estar lá, teve medo de ser internado pelo médico psiquiatra ou considerado definitivamente "louco". Com ódio e desesperança, ele falava sobre a inconsistência e desorganização dos serviços, não conseguia mais confiar nos profissionais que o atendiam, não aguentava mais atravessar a cidade por meio de encaminhamentos que não lhe ajudavam, só intensificavam seu cansaço. Achava que seu caso não tinha mais solução. Ele bebia porque sentia que estava vivendo em um corpo morto. Chegou até a considerar que a internação poderia ser o melhor no momento, mas quem iria trazer o sustento para casa?

\author{
Embriagados \\ Jogado na cidade \\ Questiono minha sanidade \\ Não tem solução \\ Insistem em me dar remédios \\ Me sinto sufocado entre as paredes desses \\ Prédios \\ E entre o tédio \\ Outra vez no psiquiatra \\ O que é claro pra ele \\ Pra mim tem forma abstrata \\ Tenta me tratar \\ Maltrata minha inteligência \\ Às vezes até duvido da sua existência (BACO, 2017) $)^{71}$
}

Merhy (2012) diz que o usuário de drogas é visto como o louco da vez por estar marginalizado pelo discurso hegemônico da dita ciência, e pelo senso comum que permeia o discurso moralista e punitivista da sociedade. Para o autor, os usuários de drogas são considerados os anormais da contemporaneidade, na medida em que o pensamento conservador e reacionário produz a construção dessa identidade 70 O termo adesão ao tratamento é recorrente nas explicações das equipes sobre o possível motivo dos usuários não frequentarem os serviços para realizar os tratamentos prescritos. Achamos importante problematizar este termo, pois esta afirmativa responsabiliza unicamente o usuário pelo fato de não desenvolver o trabalho proposto pela equipe de saúde, sem indagar o quanto a equipe e o serviço de fato flexibilizam as práticas e adaptam o cardápio de oferta para responder as reais necessidades dos usuários.

youtube.com/watch?v=5Ob6ELtdCyo. Acesso em: 17 mai. 2019. depreciativa. Identidade que não é merecedora de humanidade, logo, gera uma indiferença em relação à existência de quem é considerado/a humano/a.

$\mathrm{Na}$ experiência de José com os serviços de saúde foram reproduzidos estigmas da loucura e da culpabilização do sujeito pelo consumo do álcool. A equipe da UBS se deparou com um cenário de dificuldades em relação à articulação e diálogo interdisciplinar sobre o caso, resultando em um encaminhamento médico-centrado, onde não houve interação entre equipes, tampouco com José para construir e analisar outras possibilidades de intervenção. José não se apropriou de suas necessidades, tendo em vista que não foi considerada sua autonomia no processo, refletindo na sua dificuldade em olhar para si e na falta de oferta de cuidados que respondessem às necessidades que ele endereçava às equipes de saúde. A dificuldade da equipe em criar um espaço de compreensibilidade mútua com José e a dificuldade de diálogo entre profissionais e redes de serviços acabou espelhando na dificuldade de construir perspectivas sobre si e sobre sua vida. Qual o efeito quando esse espaço de compreensibilidade mútua sequer é pensado? Qual o impacto quando o não cuidado é produzido por quem deveria cuidar?

Afinal, os serviços que constituem a atenção básica deveriam funcionar como um ponto de escuta e acolhimento no território, permitindo a construção de vínculos e de corresponsabilização pelo cuidado e autonomia (SANTOS; FERLA, 2017).

E o CAPS-AD? Como se estabeleceu a escuta de José nesse serviço? Como foram seus encontros e desencontros com esse espaço?

José relata que após sua primeira internação psiquiátrica fora encaminhado ao CAPS-AD, pois era o serviço de saúde que deveria dar continuidade ao seu tratamento. E salienta que a internação foi a sua pior experiência. Foram muitas memórias com conteúdos densos e dolorosos, marcados pela vivência de ter sua liberdade individual limitada e restringida. Violência e pesadelo é o que marca a narrativa de José. Desde então, passou a usar da experiência da internação como recurso para não retornar ao uso de álcool e ter uma "recaída". Afinal, José argumenta: "Nada é pior que aquele lugar, faço de tudo pra nunca mais ter que voltar. Por isso que quando a psicóloga do CAPS dizia que se eu não parasse de beber eu teria que ser internado novamente, eu me desesperava. Ela sabia que eu não queria internar". Eis uma estratégia punitivista aplicada por aquela que deveria escutar, acolher, cuidar. Que deveria criar um espaço de compreensibilidade mútua entre ela e José. 
O CAPS-AD seria o local de prevenção de uma nova internação? Se sim, será a motivação da abstinência a melhor estratégia para evitar internações? Será que é somente isso que importa?

A mobilização social resultante da Reforma Psiquiátrica brasileira, e sua consolidação enquanto política de Estado, foi fundada a partir da luta por uma sociedade sem manicômios (LANCETTI, 2015). Uma luta que coloca em cena a cidadania dos usuários, de modo independente de seus diagnósticos. Por mais que seja reconfigurada com as políticas antidrogas atuais, a Reforma Psiquiátrica Antimanicomial não se dá neste limiar tendo em vista que o consumo de drogas existe desde os princípios da humanidade. Ou seja, as pessoas usam drogas desde sempre, em diversas épocas e contextos sociais. No entanto, atualmente, o usuário de drogas é considerado um sujeito sem subjetividade, desviante da norma e que necessita ser reprogramado com medidas baseadas na abstinência (LANCETTI, 2015).

Deste modo, é preciso mais do que novos modelos de cuidado para não reproduzir a lógica manicomial, punitivista, moralizante, racista em saúde; é preciso mais que renomear práticas e serviços; é preciso mais do que abandonar os jalecos brancos. É imprescindível desamarrar as travas que estão em nós, que nos subjetivam e que nos levam a reproduzir esses modelos de exclusão. Mas qual seria o caminho possível para isso?

A Redução de Danos se apresenta como uma estratégia de enfrentamento às práticas hegemônicas e cuidado que permeiam a atenção básica e os demais níveis de saúde existentes. Ela se estabelece como uma tentativa de deslocamento epistemológico, construída por movimentos sociais a partir do protagonismo dos usuários, e entendida como um modelo clínico-político para a problemática das drogas na saúde (PASSOS, 2010).

A abertura e organização dos usuários e ex-usuários de drogas para indicar aos profissionais o cotidiano de uso, assim como alertar sobre quais medidas são mais eficazes na abordagem, contribuiu para a aproximação com o campo da saúde (TOROSSIAN; PAPINI, 2018). Assim, ainda segundo a autora, a Redução de Danos foi produzida enquanto um modelo de cuidado constituído pela força da voz e experiência dos usuários de drogas, pela relevância do conhecimento no território e pelas táticas de abordagens que não são ensinadas nas faculdades das áreas da saúde. Importante salientar que os/as agentes redutores/as de danos são, comumente, usuários e/ou ex-usuários de drogas.
Enquanto diretriz ética do cuidado, a Redução de Danos não se furta ao exercício da compreensibilidade mútua, buscando estabelecer uma relação sujeito-sujeito quando o/a agente redutor/a oferece a sua presença, acompanha os percursos do usuário, escuta suas demandas, seus sofrimentos, suas histórias de vida. Trata-se de um modelo de cuidado que opera fora dos espaços de tratamento convencionais de reclusão, comprometido com medidas que desinstitucionalizam, ou seja, operam na contramão de práticas instituídas e ancoradas na ordem da exclusão (LANCETTI, 2015).

Não obstante, enquanto o estudo foi sendo desenvolvido, houve intensas mudanças no cenário político nacional, onde as políticas públicas sobre saúde mental e drogas sofreram um processo de ataque e consequentemente desmonte. Recentemente, o governo sancionou uma nova Lei sobre drogas, a Lei Federal $\mathrm{n}^{\circ}$ 13.840/2019, retirando do cenário a proposta da RD como estratégia de cuidado, apostando fundamentalmente na abstinência pela via da internação, inclusive compulsória. Tais alterações fomentam o modelo da abstinência e atenção médico-centrada como única finalidade de tratamento, desconsiderando os níveis subjetivos, psíquicos e sociais dos sujeitos. Ao mesmo tempo, o SUS vem sendo sucateado e desfinanciado, com seus investimentos limitados por 20 anos por meio da Emenda Constitucional n ${ }^{\circ}$ 95/2016, fomentando a privatização da saúde, concentração de renda e exclusão social. Quais serão as perspectivas e desafios diante dessa nova conjuntura?

Outras Palavras sobre Poder e Humanidade: Pensamento Crítico Descolonial e Redução de Danos em Diálogo

Agora é minha vez de falar o que penso

Tá preocupado com futuro do país, né?

Vomita raiva baseado no bom senso

Ódio gera ódio, e mais ódio

Onde vai chegar?

A resistência ainda vive aqui gueto! (AXANT, 2018)72

$72 \quad$ Trecho extraído da música "Primavera Fascista", com participação de Axant, Bocaum, Leoni, Felipe Ar tioli, VK Mac, Mary Jane, Adikto e Dudu. Disponível em: https://www.youtube.com/watch?v=pi2WodtwW3k. Acesso em: 17 mai. 2019. 
José, jovem negro e morador da periferia, percorreu tantas instituições na vida que nem lembra mais. Desde sua adolescência, passou por abrigos, hospitais psiquiátricos, comunidades terapêuticas e também pela Fundação de Atendimento Socio-Educativo (FASE). As drogas sempre estiveram no seu caminho, mesmo sem ele querer. O pai, dependente de álcool, foi quem ofereceu os primeiros goles de cerveja. José guardava as lembranças das noites em que acordava no meio da madrugada, escutando gritos desesperados de sua mãe, enquanto seu pai a mandava ficar quieta. Com o tempo, percebeu que quando bebia seu sono era tão profundo que ele não despertava no meio da noite. Passou a tomar uns goles todas as noites para não escutar os gritos de sua mãe.

As discussões na família só pioravam, fazendo com que ele ficasse cada vez mais tempo na rua. Gostava de estar com a galera, jogando conversa fora, fazendo umas rimas e longe de problemas. Mas sabia que os problemas estavam bem perto. Sua mãe sempre lhe dizia para ficar longe da rua, pois a biqueira ${ }^{73}$ do bairro ficava na esquina de sua casa. Sua mãe sabia e temia. Ali sempre dava problema. O problema estava na rua. Drogas. Tiros. Morte. Toda semana a notícia era a mesma, mudava só o personagem. Ele também temia, mas não tinha como fugir. Sabia o perigo de um jovem negro na periferia, frequentando o ponto de tráfico, mesmo como usuário. Sabia que a diferença entre usuário e traficante é a cor da pele. Mas tem coisas nessa vida que não se escolhe. Zé, como o chamavam seus amigos, conhecia muito bem aquela esquina. Talvez tenha sido ali que tudo começou: a maconha, a cocaína. Mas para ele era muito mais do que isso. Tudo isso fazia com que passasse ali todos os dias, depois do trabalho. Ali ele podia se sentir em casa. Era como um descarrego.

Quem é José, no tecido social brasileiro? Jovem, negro, periférico, usuário de drogas. Aquele que é indesejado, que pode ser exterminado, aquele que pode morrer como objeto descartável, como refere Mbembe (2016). Jovem negro que vivencia em seu cotidiano os efeitos produzidos pelo emaranhado raça, racismo e guerra contra as drogas.

O conceito de raça é uma abstração, uma invenção que nada tem a ver com processos biológicos (QUIJANO, 2005). Trata-se de uma "ficção útil, de uma construção fantasista ou de uma projecção ideológica", cuja necessidade de $73 \quad$ Na gíria urbana popular, biqueira é um local onde se vendem drogas, também chamado de boca de fumo ou ponto de tráfico. invenção foi fundamentar o poder do hemisfério ocidental, que se considerava "o centro do globo, o país natal da razão, da vida universal e da verdade da Humanidade" (MBEMBE, 2017, p. 27). Com a união entre raça e cor, forjada a partir do século XVI, a ideia de raça passa a ser usada como justificativa para a dominação colonial e hegemonia eurocêntrica (QUIJANO, 2005). Ou seja, a união entre raça e cor irá fundamentar a hierarquização do humano para, assim, justificar a colonização, a dominação e a exploração europeia dos continentes americano e africano.

Quais os efeitos desse processo em José, nos Josés? Mv Bill (1999) nos dá o tom:

\author{
Já pedi esmola já me humilhei \\ Fui pisoteado só eu sei que eu passei \\ Eu tô ligado não vai justificar \\ Meu tempo é pequeno não sei o quanto vai durar \\ É pior do que pedir favor \\ Arruma um emprego tenho um filho pequeno, seu doutor \\ Fila grande eu e mais trezentos \\ Depois de muito tempo sem vaga no momento \\ A mesma história todo dia é foda \\ É isso tudo que gera revolta \\ Me deixou desnorteado mais um maluco armado \\ Tô ligado bolado quem é o culpado? \\ Quem fabrica a guerra e nunca morre por ela \\ Distribui a droga que destrói a favela \\ Fazendo dinheiro com a nossa realidade \\ Me deixaram entre o crime e a necessidade (MV BILL, 1999)
}

A hierarquização do humano impõe ao José uma humanidade de concessão e subalterna enquanto herança colonial no contemporâneo, uma existência negra pautada e a serviço da colonialidade do poder (ALVES; JESUS; SCHOLZ, 2015) e da manutenção da supremacia branca.

Conforme Fanon (2005), o colonialismo europeu efetivou mundialmente a hierarquia e a dominação racial dos brancos em relação aos negros por meio de uma cisão racializada. Produziu-se uma lógica colonial de supremacia branca que extrapola os limites e particularidades do colonialismo histórico, e que não desaparece mesmo após uma suposta independência ou descolonização dos povos 
colonizados, ou seja, a colonialidade do poder (QUIJANO, 1997). Portanto, é na hierarquização do humano e na supremacia branca que o racismo estrutura as relações sociais em nosso país.

Para o Estado, a zona de guerra e violência opera em nome da "civilização" e da "racionalidade" (MBEMBE, 2016, p. 133). O autor refere que com o advento da modernidade, o Estado cria novas formas de eliminação e execução dos indesejados, de modo que a noção de quem pode viver ou morrer está intimamente ligada à manutenção do poder capitalista. O poder capitalista se constitui a partir das suas formas de exploração, dominação e hierarquização dos sujeitos, o que implica no controle das instâncias básicas da existência social como trabalho, subjetividade, autoridade (QUIJANO, 1978). A colonialidade não pode ser compreendida como algo decorrente nem antecedente da modernindade, mas sim, "colonialidade e modernidade constituem duas faces de uma mesma moeda" (GROSFOGUEL, 2008, p. 125).

José abandonou a escola e passou a viver com um salário de ajudante de pedreiro. Em uma noite fria e estrelada, estava cansado e exausto após um dia intenso de trabalho pesado. Passou na esquina para comprar sua maconha, pois dizia relaxar a dor do corpo e ajudava a dormir melhor. Mas depois deste dia, Zé nunca mais dormiu do mesmo jeito. Em uma intervenção policial, foi preso junto com todos que estavam na esquina. Tiros. Sirenes. Gritos. De modo semelhante Racionais Mc's utilizam a música para denunciar a cultura da violência racista:

\author{
Periferias, vielas, cortiços \\ Você deve tá pensando: O que você tem a ver com isso? \\ Desde o início por ouro e prata \\ Olha quem morre, então veja você quem mata \\ Recebe o mérito, a farda que pratica o mal \\ Me ver pobre, preso ou morto já é cultural (RACIONAIS MC’S, 2002)
}

Como ainda era adolescente, "menor"74 de idade, passou um ano na FASE e saiu. Disse somente que foram tempos difíceis. Pensa que até teve sorte, poderia estar morto. Mas pensando bem nem deveria ter parado lá. Justificou, alegando que é $74 \quad$ No Brasil, a primeira norma específica para crianças e adolescentes foi o Código de Menores, instituído em 1979. Destinado aos jovens que estivessem em "situação irregular" ou "inadaptados"; continha um caráter discriminatório, associando pobreza à delinquência; funcionava como um instrumento de controle, transferindo a tutela dos ditos "menores" ao Estado e, assim, justificando ações repressivas (BRASIL, 1979). O Código de Criança e do Adolescente (ECA) pela Lei Federal n ${ }^{\circ} 8.069 / 1990$ (BRASIL, 1990). usuário, mas ninguém acreditou. Eles só queriam apontar os culpados, não importava quem fosse. E ele estava lá, foi flagrante. Sem dinheiro para se defender, o melhor foi aceitar o acordo da justiça. Lá dentro, ele escutava muito rap com a galera e pensava como seria sua liberdade. Lembrou-se do verso do Djonga (2018) em Favela Vive 3:

\author{
Eu sei, eu sei \\ Parece que nós só apanha \\ Mas no meu lugar se ponha e suponha que \\ No século 21, a cada 23 minutos morre um jovem negro \\ E você é negro que nem eu, pretin, ó \\ Não ficaria preocupado? \\ Eu sei bem o que cê pensou daí \\ Rezando não tava, deve ser desocupado \\ Mas o menor tava voltando do trampo \\ Disseram que o tiro só foi precipitado \\ No mais, saudade dos amigo que se foi \\ P.J.L. pros irmão que tá na tranca (DJONGA, 2018)
}

$\mathrm{Na}$ modernidade/colonialidade são criadas novas classificações sociais a partir das relações hierárquicas entre os sujeitos (MALDONADO-TORRES, 2007). José, jovem negro periférico usuário de drogas!

Ainda no período colonial, o uso recreativo de drogas se restringia aos homens brancos de elite, posteriormente, estendendo-se às mulheres brancas da mesma classe (SANTOS JÚNIOR, 2016). Aos sujeitos negros e imigrantes que faziam uso de drogas foi construída uma imagem de desobediência da Lei, produzindo no imaginário social a ideia de homem negro bandido e usuário de drogas (SANTOS JÚNIOR, 2016). Classificação social cujos sujeitos, na relação com o Estado, devem ser eliminados. Eis o modo como o Estado se relaciona com José, e com outros tantos Josés, por meio das instâncias policiais e da "justiça" criminal. Essa é a experiência de muitos Josés que encontramos em becos e vielas a partir do trabalho de agentes redutores/as de danos.

Experiência vivida em meio à colonialidade do poder e a seus efeitos nos modos de ser, de existir, isto é, a colonialidade do ser; esta que irá relacionar os efeitos da colonialidade do poder à não existência do "Outro" (MALDONADO-TORRES, 2007), de modo a negar sistematicamente sua humanidade (FANON, 2005). A 
colonialidade do ser produz uma condição existencial subalterna para sujeitos negros e negras cujas relações subjetivas e intersubjetivas partem de modos de existir ocidentalizado (ALVES; AMARAL, 2018). Portanto, a colonialidade do ser surge como um desdobramento da colonialidade do poder, no sentido da necessidade de pensar os efeitos da colonialidade na experiência subjetiva dos sujeitos.

Assim, podemos problematizar o quanto a condição existencial de José, imposta pela modernidade/colonialidade, determina sua experiência como sujeito subalternizado no tecido social. Baco (2017) coloca-nos a refletir:

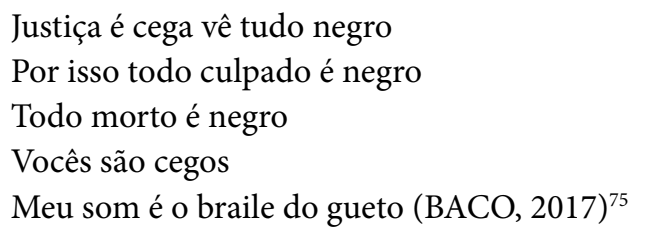

Depois da prisão, o pai de José não o aceitou mais em casa. Então ele passou um tempo nas ruas, em abrigos, em casas estranhas. O álcool e a cocaína cada vez mais presentes em sua vida, amenizando os riscos constantes da rua. Os danos, as dores e a violência. Um dia, sua mãe descobriu seu paradeiro e foi interná-lo. Foi estranho, mas ele aceitou, confiou na ajuda, também queria sair das ruas. Foi internado em um hospital psiquiátrico, lugar que parecia uma prisão. José visitou várias vezes a cadeia, ia frequentemente ver seu primo e alguns amigos que estavam lá. Não tinha dúvidas que o hospital psiquiátrico era pior. Lá ficou preso em uma cama, e os profissionais o medicavam tanto que não sabia definir se era noite ou dia. Ele ficou um mês, mas sente que foi mais de um ano. As lembranças e imagens daquele lugar lhe fazem mal até hoje, mesmo tendo passado por tantas dificuldades na vida. Já viu gente morrer assassinada, torturada, mulheres e crianças apanhando. Mas em nenhum outro lugar foi olhado com tamanha desumanidade, encarcerado e medicado para não ser capaz nem de pensar. Teve momentos em que esqueceu o motivo de estar ali. Não lembrava. Será que estava ficando louco, ou foi aquele lugar que o deixou assim? Será que sempre foi louco e nunca percebeu? Tentou se lembrar mas não conseguiu, a cabeça doía e latejava. Era como se estivesse se esquecendo da sua própria história. com/watch?v=cuXZ-hKzpqg. Acesso em: 17 mai. 2019.
Acordou pra vida com cem bolhas no corpo

Com ladrão apagando na pele dois maços de Marlboro

$\mathrm{O}$ ódio atravessou a fronteira da favela

Pra decretar que paz é só embaixo da terra

Não sou eu que a impunidade beneficia

Me diz quantos Nicolau tão na delegacia

Quer o fim do barulho de tiro a noite

Faz abaixo-assinado contra taurus colt

A fábrica de armas tá a mil na produção

Contrabandeando pro Rio, SP, Afeganistão

E a cada bala no defunto, um boy sai no lucro

Na guerra o mais inocente é o favelado de fuzil russo (FACÇÃO CENTRAL, 2003)

Com a modernidade/colonialidade, o "progresso" passou a significar, essencialmente, "progresso" só para alguns, à medida que os direitos humanos não se aplicam igualmente para todos, assim como a segurança de alguns se obtém por meio do custo de vida de outros (MALDONADO-TORRES, 2007). Ou seja, esse ceticismo misantrópico garante que algumas identidades manifestem superioridade sobre outras, ao passo que o grau de superioridade se justifica em relação à medida de humanidade que se atribuem às identidades (MALDONADOTORRES, 2007). Qual a medida de humanidade que se atribui à existência de José? Como seriam suas experiências diante de tais situações, se José fosse um jovem branco de classe média-alta?

Alguns anos depois, influenciado por amigos próximos, ele considera a possibilidade de se internar em uma Comunidade Terapêutica. Mesmo com receio pelas suas experiências, decidiu confiar no que ouvia das pessoas. Lá é diferente, diziam, um lugar amigável, onde muitos se recuperam, sem aquela agressividade toda. José aceitou, movido por uma antiga, e também nova, esperança de melhorar. Ele percebeu que era diferente. Mas não como esperava. Realmente foi um lugar em que fez muitos amigos, todos compartilhando a dureza dessa existência marcada pelo descaso e pela violência. Acreditava em Deus. Sempre teve sua própria fé. Mas não entendia o caminho de Deus da forma que os profissionais de lá pregavam. Não ficava preso, mas se sentia preso. Questionavase por que tinha que ficar longe da sua família. Aquela não era sua vida real. Com 
o tempo, percebeu que aquele lugar também era uma prisão. Diferente das outras prisões que já estivera, essa não tinha algemas, nem amarrava. Ela adestrava. E se antes José se sentia um animal descontrolado, agora parecia mais com um animal domado e reprimido.

Diante da conjuntura atual do país, podemos analisar que a nova política antidrogas intensifica a guerra contra as drogas, a qual nunca foi totalmente superada. Com o retrocesso à lógica da abstinência e da internação compulsória como base da Lei no 13.840/2019, retornamos à condição de exclusão dos usuários, criminalização do consumo, e encarceramento em massa.

Sabemos que a guerra contra as drogas é seletiva, com recorte de classe e cor, atingindo as populações mais vulneráveis, com quem são empregados os métodos mais violentos. Humilhação, tiros, revistas, violência física, psicológica, racista, execução, silenciamento. Um modelo ineficaz para combater as drogas e para cuidar dos sujeitos.

A colonialidade do poder e do ser gera, necessariamente, um conjunto de sujeitos humilhados, esquecidos e marginalizados (MIGNOLO, 2007). Nesse sentido, arriscamo-nos a dizer que a colonialidade do poder e do ser se expressa nas práticas de cuidado presentes nos serviços de saúde, principalmente no que se refere ao cuidado em saúde mental de usuários de álcool e outras drogas. Práticas agora legitimadas pela nova política antidrogas, que de pronto subtrai o sujeito desta equação. Novamente é a droga que está no centro das atenções e não o sujeito, sua família, seu contexto social.

Sendo assim, consideramos a Redução de Danos como uma estratégia potente de enfrentamento à colonialidade do poder e do ser, entendendo-as no processo de naturalização de práticas de eliminação e subalternização de sujeitos por meio da violação de direitos, e de modos de existir. Genocídio físico, violação corporal e violência racista. A Redução de Danos tem a potencialidade de criar espaços de compreensibilidade mútua entre sujeitos, abrindo caminhos para a humanização de práticas em saúde.

José, ora de meia idade, ora jovem, ora branco, ora negro, em todas essas possibilidades, homem cis, periférico, usuário de drogas, quando jovem e negro também estava em situação de rua. Foram muitos os Josés aqui escrevividos. Como seria se, em algum momento de suas vidas, eles tivessem encontrado com um/uma agente redutor/a de danos? Como seria se ele, jovem negro e morador da periferia, ou se ele, branco de meia idade e morador de periferia, tivesse a oportunidade de vivenciar alguma estratégia de Redução de Danos? Se eles tivessem conhecido algum/alguma agente redutor/a de danos que lhe apresentasse outro modo de tratamento que não fosse abstinência e encarceramento? Como seria se alguém tivesse reconhecido a humanidade desses Josés?

A Redução de Danos se coloca em uma postura da defesa e afirmação da vida. É uma clínica em movimento, com autonomia. Como seria se José fosse cuidado com esse olhar a favor da liberdade? Apesar de sua eliminação como política do Estado, ela segue existindo enquanto movimento e prática de cuidado, na micropolítica, não somente a partir de uma necessidade de cuidado em saúde mental, mas, sobretudo, como um modo de existir e (re)existir.

\section{Referências}

ALVES, Míriam Cristiane; AMARAL, Tatiane Coelho. Ações afirmativas, subjetividades e (re)existências: estudantes negros e negras cotistas no curso de Psicologia da UFPEL. In: CALAZANS, Márcia Esteves de; CASTRO, Mary Garcia; PIÑEIRO, Emilia (Orgs.). América Latina, volume 2: corpos, trânsitos e resistências. Porto Alegre, RS: Fi, 2018. p. 97-124.

ALVES, Míriam Cristiane; JESUS, Jayro Pereira de; SCHOLZ, Danielle. Paradigma da afrocentricidade e uma nova concepção de humanidade em saúde coletiva: reflexões sobre a relação entre saúde mental e racismo. Saúde em Debate, Rio de Janeiro, v. 39, n. 106, p. 869-880, set. 2015.

AMARO, Tainá Valente; ALVES, Míriam Cristiane; MOLON, Susana Inês. Trajetórias e (Re)existências de Mulheres Pretas Psicólogas. In: CRP - Conselho Regional de Psicologia. Núcleo de relações Raciais: Percursos, Histórias e Movimentos. Porto Alegre: CRPRS, 2019. p. 28-50. Disponível em: http://crprs.org. br/publicacoes/nucleo-de-relacoes-raciais-percursos-historias-e-movimentos. Acesso em: 27 ago. 2019.

ARAUJO, Tarso. Almanaque das drogas: um guia informal para o debate racional. 2. ed. São Paulo: Leya, 2014.

AXANT. Primavera Fascista. Intérpretes: Bocaum, Leoni, Felipe Artioli, VK Mac, Mary Jane, Adikto, Axant, Dudu. Selo: Setor Proibido. 2018. Disponível em: https://www.youtube.com/ watch?v=pi2WodtwW3k. Acesso em: 17 mai. 2019.

BACO, Exu do Blues. Álbum Esú. Selo: Independente. 2017.

BK'. O céu é o limite. Devasto Prod. Intérpretes: Djonga, Emicida, Mano Brown, Rincon Sapiência, BK', Rael. 2018. Compositores: BK', Djonga, Emicida, Mano Brown, Rincon Sapiência e Rael. Devasto Prod, 2018. Disponível em: https://www.youtube.com/watch?v=zMBKjt hQl4. Acesso em: 17 mai. 2019.

BRASIL. Lei Federal 8069 de 13 de julho de 1990. Dispõe sobre o Estatuto da Criança e do Adolescente e dá outras providências. Diário Oficial da União, Brasília, 27 de agosto de 1990.

BRASIL. Ministério da Saúde. Portaria no 224 de 29 de janeiro de 1992 Diretrizes e Normas para o Atendimento Ambulatorial/Hospitalar em Saúde Mental. Diário Oficial da União, Brasília, 30 de janeiro de 1992. 
BRASIL. Lei Federal no 10216 de 6 de abril de 2001. Dispõe sobre a proteção e os direitos das pessoas portadoras de transtornos mentais e redireciona o modelo assistencial em saúde pessoas portadoras de transtornos mentais e redireciona
mental. Diário Oficial da União, Brasília, 9 de abril de 2001.

BRASIL. Emenda Constitucional no 95 de 15 de dezembro de 2016. Altera o Ato das Disposições Constitucionais Transitórias, para instituir o Novo Regime Fiscal, e dá outras providências. Diário Oficial da União, Brasília, 15 de dezembro de 2016.

BRASIL. Lei Federal no 13.840 de 5 de junho de 2019. Dispõe sobre o Sistema Nacional de Políticas Públicas sobre Drogas e as condições de atenção aos usuários ou dependentes de drogas e para tratar do financiamento das políticas sobre drogas. Diário Oficial da União, Brasília, 6 de junho de 2019.

BRASIL. Ministério da Saúde. Portaria n ${ }^{\circ} 336$ de 19 de fevereiro de 2002. Estabelece os Centros de Atenção Psicossocial e dá outras providências. Diário Oficial da União, Brasília, 19 de fevereiro de 2002.

BRASIL. Ministério da Saúde. Portaria no 4.279 de 30 de dezembro de 2010. Estabelece diretrizes para a organização da Rede de Atenção à Saúde no âmbito do Sistema Único de Saúde (SUS). Diário Oficial da União, Brasília, 30 de dezembro de 2010.

BRASIL. Ministério da Saúde. Portaria no 3088 de 23 de dezembro de 2011. Institui a Rede de Atenção Psicossocial para pessoas com sofrimento ou transtorno mental e com necessidades decorrentes do uso de crack, álcool e outras drogas, no âmbito do Sistema Único de Saúde (SUS).Diário Oficial da União, Brasília, 23 de dezembro de 2011.

BRASIL. Ministério da Saúde. Secretaria Executiva Coordenação Nacional de DST e AIDS. A política do Ministério da Saúde para a atenção integral a usuários de álcool e outras drogas. Brasília: Ministério da Saúde, 2003.

BRASIL. Ministério da Saúde. Portaria n ${ }^{\circ} 3588$, de 21 de dezembro de 2017. Altera as Portarias de Consolidação, de 28 de setembro de 2017, sobre a Rede de Atenção Psicossocial. Diário Oficial da União, Brasília, 22 dez. 2017.

CABRAL, Károl Veiga; SIMONI, Ana Carolina Rios; FAGUNDES, Sandra Maria Sales. Saúde Mental em Campo: da lei da reforma psiquiátrica ao cotidiano do cuidado. Porto Alegre: Rede Unida, 2019.

CLASEN, Suelen Lemons; ALVES, Cristiane Alves. Mulheres que vivenciam o aprisionamento institucional: problematizações sobre modos de (re)existência e de subversão à colonialidade. In: CRP - Conselho Regional de Psicologia. Núcleo de relações Raciais: Percursos, Histórias e Movimentos. Porto Alegre: CRPRS, 2019. p. 119-129. Disponível em: http://crprs.org.br/publicacoes/nucleo-derelacoes-raciais-percursos-historias-e-movimentos. Acesso em: 27 ago. 2019.

CORTES, Laura; TERRA, Marlene; PIRES, Fábio; HEINRICH, Juliane; MACHADO, Katiusci; WEILLER, Teresinha; PADOIN, Stella. Atenção a usuários de álcool e outras drogas e os limites da composição de redes. Rev. Eletr. Enf, v.16, n.1, p. 84-92, jan./mar. 2014.

COSTA. Pedro; RONZANI, Telmo; COLUGNATI, Fernando. "No papel é bonito, mas na prática..." Análise sobre a rede de atenção aos usuários de drogas nas políticas e instrumentos normativos da área. Saúde Sociedade, São Paulo, v. 26, n.3, p. 738-750, 2017

DJONGA. Favela Vive 3. ADL MC'S. Part. Lord, Choice, Negra Li, Menor do Chapa. 2018.

EMICIDA. AmarElo. Sample: Belchior - Sujeito de Sorte.Part. Majur e Pablo Vittar. Composição: Felipe Vassão/DJ Duh/ Emicida/Belchior. 2019. Disponível em: https://www.youtube.com/ watch?v=PTDgP3BDPIU. Acesso em: 20 mai. 2019.

EVARISTO, Conceição. [Entrevista cedida a] Ellen Oléria, Fefito e Mel Gonçalves. São Paulo: TV Brasil, 2017. Entrevista realizada no Programa Estação Plural, da TV Brasil. Disponível em: https://www.youtube.com/watch?v=Xn2gj1hGsoo. Acesso em: 20 mai. 2019.
EVARISTO, Conceição. Insubmissas Lágrimas de Mulheres. Rio de Janeiro: Malê, 2016.

EVARISTO, Conceição. Olhos D’água. Rio de Janeiro: Pallas Fundação Biblioteca Nacional, 2014. FACÇÃO CENTRAL. Hoje Deus anda de blindado. Álbum Direto do Campo de Extermínio. 2003. FANON, Frantz. Os condenados da terra. Juiz de Fora: UFJF, 2005

FANON, Frantz. Pele negra, máscaras brancas. Tradução de Renato da Silveira. Salvador: Edufba, 2008. GONDINHO, Brunna; BULGARELI, Jaqueline; CORTELLAZZI, Karine; MIALHE, Fábio; OLIVEIRA, Cláudia; MENEGHIM, Marcelo; PEREIRA, Antonio; POSSOBON, Rosana; GUERRA, Luciane. A Atenção ao usuário de álcool e outras drogas sob o olhar dos gestores de saúde. Atas - Investigação Qualitativa em Saúde, v. 2, 2018. Disponível em: https://proceedings. ciaiq.org/index.php/ciaiq2018/article/view/1817. Acesso em: 27 mai. 2019.

GROSFOGUEL, Ramón. Tradução de Inês Martins Ferreira. Para descolonizar os estudos de economia política e os estudos pós-coloniais: Transmodernidade, pensamento de fronteira e colonialidade global. Revista Crítica de Ciências Sociais, 80, p. 115-147, mar. 2008.

MARTÍNEZ-HERNÁEZ, Angel. Antropología Médica: teorías sobre la cultura, El

poder y la enfermedad. Barcelona: Anthropos Editorial, 2008.

LABATE, Beatriz Caiuby; GOULART, Sandra Lucia; FIORE, Mauricio; MACRAE, Edward; CARNEIRO, Henrique. Drogas e cultura: novas perspectivas. $1^{\circ}$ ed. Salvador: EDUFBA, 2008.

LANCETTI, Antonio. Contrafissura e plasticidade psíquica. São Paulo: Hucitec, 2015.

LEONI. Primavera Fascista. Intérpretes: Bocaum, Leoni, Felipe Artioli, VK Mac, Mary Jane, Adikto, Axant, Dudu. Selo: Setor Proibido. 2018. Disponível em: https://www.youtube.com/ watch?v=pi2WodtwW3k. Acesso em: 17 mai. 2019.

LIMA, Ana Izabel; DIMENSTEIN, Magda. O consumo de álcool e outras drogas na atenção primária. Cadernos Brasileiros de Saúde Mental, Florianópolis, v.10, n.26, p.46-65, 2018.

LK. Poetas No Topo 3.2. Compositores: Raillow, Xamã, Síntese, LK, Choice, Lord, Ghetto ZN, Leal. Produção: Slim - TH. Pineapple Supply, 2017.

MALDONADO-TORRES, Nelson. Sobre la colonialidad del ser: contribuciones al desarrollo de un concepto. In: CASTRO-GÓMEZ, S. et al (Orgs.). El giro decolonial: reflexiones para una diversidad epistémica más allá del capitalismo global. Bogotá: Siglo del Hombre Editores; Universidad Central, Instituto Pensar, 2007. p. 127-168.

MERHY, Emerson Elias. Ato de cuidar: a alma dos serviços de saúde. In: Saúde: cartografia do trabalho vivo em ato. São Paulo: Hucitec, 2002. p. 115-135.

MERHY, Emerson Elias. Anormais do desejo: os novos não humanos? Os sinais que vêm da vida cotidiana e da rua. In: Conselho Federal de Psicologia. Grupo de Trabalho de Álcool e outras Drogas. Drogas e cidadania: em debate. Brasília, DF: CFP, 2012. p. 9-18.

MIGNOLO, Walter. El pensamiento Decolonial: Desprendimiento y apertura. In: CASTRO GÓMEZ, en Santiago coord. El giro Decolonial. IESCO: Bogotá, 2007. p.25-47.

MBEMBE, Achille. Necropolítica. Arte \& Ensaios (Revista do Programa de Pós-Graduação em Artes Visuais, Escola de Belas Artes, UFRJ).v.2, n.32, dez. 2016. Disponível em: https://revistas. ufri.br/index.php/ae/article/view/8993/7169. Acesso em: 17 mai. 2019.

MBEMBE, Achile. Crítica da Razão Negra. 2a Ed. Lisboa, Portugal: Antígona, 2017.

MV BILL. Soldado do Morro. Álbum Traficando Informação. 1999. 
PASSOS, Eduardo. Prefácio. Pensar diferentemente o tema das drogas e o campo da saúde mental. In: SANTOS, Loiva Maria De Boni (Org.). Outras Palavras sobre o cuidado de pessoas que In: SANTOS, Loiva Maria De Boni (Org.). Outras Palavras sobre o cuidado de pessoas que
usam drogas. Porto Alegre, RS: Ideograf/ Conselho Regional de Psicologia do Rio Grande do usam drogas. Po
Sul, 2010. p.7-14.

PETUCO, Dênis Roberto da Silva. Pra não dizer que não falei de drogas. O cuidado de pessoas que usam drogas e a luta antimanicomial. In: SANTOS, Loiva Maria De Boni (Org.). Outras Palavras sobre o cuidado de pessoas que usam drogas. Porto Alegre, RS: Ideograf/ Conselho Palavras sobre o cuidado de pessoas que usam drogas. Porto A
Regional de Psicologia do Rio Grande do Sul, 2010. p. 53-64.

QUIJANO, Aníbal. Colonialidad y Modernidad/Racionalidad. Perú Indígena, Lima, v.13, n.29, p. 11-21, 1991.

QUIJANO, Aníbal. Colonialidad del poder, cultura y conocimiento en América Latina. Anuario Mariateguiano, Lima, Peru, v. 9, n. 9, p. 113-122, 1997.

QUIJANO, Aníbal. Notas sobre o Conceito de Marginalidade Social. In: PEREIRA, Luiz (Org.). Populações “Marginais”. São Paulo: Duas Cidades, 1978.

QUIJANO, Aníbal. Colonialidade do poder, eurocentrismo e América Latina. In: LANDER, Edgardo (Org.). A colonialidade do saber: eurocentrismo e ciências sociais. Perspectivas latino-americanas. Buenos Aires: CLACSO, 2005. p.117-142.

RACIONAIS MC'S. Negro drama. Álbum: Nada como um dia após o outro. São Paulo: Cosa Nostra, 2002. RIBEIRO, Djamila. O que é Lugar de fala? Belo Horizonte: Letramento: Justificando, 2017.

RIO GRANDE DO SUL. Lei Estadual n ${ }^{\circ} 9.716$ de 7 de agosto de 1992. Dispõe sobre a Reforma Psiquiátrica no Rio Grande do Sul, determina a substituição progressiva dos leitos nos hospitais psiquiátricos por rede de atenção integral em saúde mental, determina regras de proteção aos que padecem de sofrimento psíquico, especialmente quanto às internações psiquiátricas compulsórias e dá outras providências. Diário Oficial do Estado do Rio Grande do Sul, Porto Alegre, 7 de agosto de 1992.

SANTOS, Francéli Francki dos; FERLA, Alcindo Antônio. Saúde mental e atenção básica no cuidado aos usuários de álcool e outras drogas. Interface, Botucatu, v.1, n. 63, p. 833-844, 2017.

SANTOS JÚNIOR, Rosivaldo Toscano dos. A guerra ao crime e os crimes da guerra: uma crítica descolonial às políticas beligerantes no Sistema de Justiça Criminal Brasileiro. 2016. $423 \mathrm{f}$ Tese (Doutorado em Ciências Jurídicas)- Universidade Federal da Paraíba, João Pessoa, 2016.

SANTOS, Milton. Pensando o espaço do homem. São Paulo: Hucitec, 2003

SIQUEIRA, Domiciano. Construindo a descriminalização. In: SANTOS, Loiva Maria De Boni (Org.). Outras palavras sobre o cuidado de pessoas que usam drogas. Porto Alegre, RS: Ideograf/ Conselho Regional de Psicologia do Rio Grande do Sul, 2010. p. 65-70.

SOUZA, Lívia Maria. Uma reflexão sobre os discursos menores ou A escrevivência como narrativa subalterna. Revista Crioula, n.21, p.25-43, 2018.

TOROSSIAN, Sandra Djambolakdjian; PAPINI, Pedro Augusto. Vozes em rede: A experiência da Rede Multicêntrica em educação permanente em redução de danos. In: PAULON, Simone Mainieri; OLIVEIRA, Carmen Silveira de; FAGUNDES, Sandra Maria Sales (Orgs.). 25 anos da lei da reforma psiquiátrica no Rio Grande do Sul [recurso eletrônico]. Porto Alegre: Assembléia Legislativa do Estado do Rio Grande do Sul. Comissão de Saúde e Meio Ambiente, 2018. p. 271282. Disponível em: https://www.lume.ufrgs.br/handle/10183/179338. Acesso em: 22 jul. 2019.

VARELA, Danielle; SALES, Isabela Maria; SILVA, Fernanda; MONTEIRO, Claudete. Rede de saúde no atendimento ao usuário de álcool, crack e outras drogas. Escola Anna Nery, Rio de Janeiro, v. 20, n. 2, p. 296-302, 2016.
Mirian Teresa de Sá Leitão Martins

\author{
“- Lula! \\ - Pronto, patrão.
}

- Monte na bestinha melada e risque. Vá ligeiro buscar Samarica parteira que Juvita já tá com dor de menino....

Samarica sartou do cavalo véi embaixo,

cumprimentou o Capitão, entrou pra camarinha, vestiu o vestido verde e amarelo, padrão nacioná,

amarrou a cabeça c'um pano e foi dando as instrução:

- Acende um incenso. Boa noite, D. Juvita.

- Ai, Samarica, que dô!

- É assim mermo, minha fỉa, aproveite a dô. Chama as muié dessa casa, p̉a rezá a oração de São Reimundo, que esse cristão vem ao mundo nesse instante. Bá noite, cumade Tota ...” (Samarica parteira de Luiz Gonzaga, 1974)

"Samarica" que "sarta" do cavalo, acende incenso e que chama as "muié" para "reza". Mas quem é essa mulher? São muitas espalhadas por aí, nomeadas de diversas formas: "mulheres que atendem as outras mulheres", "bruxas",' anjos das florestas", "curiosas”. São elas, as "Samaricas” que dominam o partejar. Por que falar delas? E de partos, parteiras, obstetrícias, enfermeiras, médicas e parturientes? Porque é um desafio posto. Mas, são elas as mulheres, as protagonistas de todo o processo, ah isso são! E muitas falam e contam suas trajetórias.

São narrativas que se somam e se confundem com histórias, cheiros das mais diferentes ervas medicinais, suores, odores dos centros cirúrgicos, gritos, risos, luzes, olhares e afagos cúmplices ou não. São histórias que fazem parte das minhas memórias de conversas com quilombolas e caiçaras de Paraty, com minha mãe, com pacientes (da época que ainda era psicóloga clínica), das trocas produzidas de anos no labor em saúde/educação. Por isso trago a narrativa popular que fala desse ofício, que se entrelaça com a nossa cultura, e que é a celebração das parteiras, cantadas em verso e prosa, para iniciar as discussões. E indago a personagem:

$76 \quad$ Trata-se de uma performance oral, com fundo musical de Luiz Gonzaga gravado pelo mesmo no LP Sangue Nordestino pela gravadora Odeon, no ano de 1974. 
Mas o que há de mágico e tão perigoso no nascimento, que precisa ser regulado, disputado e reverenciado, "Samarica"? Tenho também histórias para contar...

São essas as discussões que trago no presente texto, que procura analisar a seguinte questão: o conhecimento e o ofício de parteiras em comunidades tradicionais, na atualidade, são práticas de resistência ao contexto hegemônico.

O partejar, o ofício das parteiras faz parte da história da própria humanidade e desde os primórdios é considerada uma prática eminentemente feminina, tendo as mulheres como protagonistas - uma mulher auxiliando a outra. O parto tem sido palco de disputas e tensões, e passou a ser tratado como um evento patológico e, portanto, medicalizado.

Carlos Zolla (1986) ressalta que as parteiras têm o reconhecimento da comunidade pelos seus conhecimentos, habilidades e as faculdades curativas. Benedita Pinto (2002) traz a relação com os ancestrais que essas mulheres possuem e dominam diante das mais diversas práticas curativas, benzendo, recitando as rezas e invocando encantarias no intuito de ter ajuda na hora do parto e na cura das doenças. Já Oliveira (2007) aborda a transmissão oral desse saber, sinalizando que ele é passado para mulheres escolhidas, que podem ser uma sobrinha, uma parenta. E essa tal pessoa dever ter esse dom, e só então pode a partir daquele momento acompanhar a "parteira veia".

Revela-se assim a existência de um conhecimento produzido por mulheres presente em práticas de saúde tradicionalmente vivenciadas em comunidades culturalmente diferenciadas, como as indígenas e as quilombolas, e que as mesmas resistem ao tempo. Conhecimento que foi gradativamente sendo estigmatizado, com a consolidação da medicina como profissão e ciência, a partir do Séc. XVIII, nas sociedades eurocêntricas em que se consolidavam as Faculdades de Medicina e Cirurgia, e consequentemente a profissão médica, no início predominantemente masculina.

A deslegitimação dos saberes e conhecimentos dos nossos ancestrais negros e indígenas foram 'produzidas pelos discursos biomédicos, baseados no saber/poder eurocêntrico e colonizador. Entendendo que os discursos são um conjunto de enunciados em um determinado campo de saber e momentos históricos. Para Foucault (1996) existiria três efeitos de exclusão dos discursos: a interdição, a separação e uma rejeição, na oposição razão e loucura, e a vontade de verdade, que apoia-se sobre um suporte institucional, e é reconduzida pelo modo como o saber é aplicado em uma sociedade, como é valorizado, distribuído, retribuído e de certo modo atribuído (FOUCAULT,1996, p.17). Ou ainda, “(...) creio que essa vontade de verdade assim apoiada sobre um suporte e uma distribuição institucional, tende a exercer sobre os outros discursos uma espécie de pressão, um poder de coerção" (FOUCAULT,1996, p. 18).

Um dos três grandes sistemas de exclusão que atinge os discursos - a vontade de verdade - baseada na oposição entre o que é o verdadeiro e o falso (FOUCAULT, 1996), permite analisar a legitimação do discurso científico e a discriminação dos saberes tradicionais. Sendo que o primeiro tem como base o saber racionalista de matriz europeia e vai configurar práticas na saúde da mulher, e no caso específico, no parto.

No que se refere especificamente ao evento do parto, temos uma virada. Este foi transferido da vida social para a competência dos médicos. E foi legitimado por um saber, a "vontade de verdade" dos especialistas, que tomaram para si a partir do Séc. XIX, a assistência materna-infantil.

A interferência da medicina nos mais diferentes atos da vida vem sendo reproduzida na maioria das sociedades desde a modernidade, período em que os conhecimentos fundantes das ciências da saúde são institucionalizados e tomados como verdadeiros em detrimento de outros conhecimentos, especialmente os tradicionais. Na modernidade se expande o sistema colonizador europeu sobre os povos e territórios americanos e africanos.

Como cita Edgardo Lander

Asprincipaisvertentes do pensamento queforam historicamentehegemônicas sobre e a partir da América Latina podem ser caracterizadas como colonialeurocêntricas. É possível identificar nestas correntes hegemônicas um substrato colonial que se expressa na leitura destas sociedades a partir da cosmovisão europeia e seu propósito de transformá-las à imagem e semelhança das sociedades do Norte, que em sucessivos momentos históricos serviram de modelo a ser imitado (LANDER, 2001, p. 23).

Uma lógica colonizadora que (re)produz discursos, que legitimam sua construção de conhecimento em detrimento de outros. É o padrão europeu que se apresenta incorporado nos "sujeitos da ciência" com seus métodos e mecanismos de controle e comprovação científica (QUIJANO, 2005). 
Em contrapartida autores como Jean Langdon (1992) e Richard Leiban (1977), entre outros, vão questionar os pressupostos racionalistas que se aproximam das concepções da Antropologia Evolucionista que tomam outras culturas como menores por não ter a racionalidade dos "homens civilizados". E, deste modo, veem os conhecimentos da medicina científica como superiores aos conhecimentos das comunidades tradicionais.

A partir do pensamento crítico decolonial ${ }^{77}$ temos a possibilidade de construir outros enunciados e "sujeitos de saber", na perspectiva de produzir possibilidades de resistência aos modelos explicativos globais, hegemônicos, eurocêntricos, considerando a potência dos saberes tradicionais, que se mantêm secularmente.

Para Bárbara Oliveira (2007) o trabalho das parteiras retrata relações ancestrais que se mantiveram como resistência ao hegemônico nas comunidades quilombolas. A autora salienta que "nenhuma parteira presta auxílio sozinha, conta-se com a presença de várias mulheres", de modo que "cada uma tem uma função específica no parto, assim como tem também o marido, a mãe da parturiente, a bezendeira, a vizinha” (2007, p.14). Nessa prática há a transmissão de conhecimentos sobre o parto “(...) a tradição oral envolve, há gerações, o conhecimento sobre o parto, os remédios tradicionais, as plantas, as garrafadas" (OLIVEIRA, 2007, p.14).

São formas autônomas de cuidado em saúde presente em comunidades quilombolas, evidenciando que o nascer e o morrer se dão, ainda, no seio dessas comunidades (OLIVEIRA, 2007), e acrescentaria, em outros contextos tradicionais. Entender essa questão a partir da Antropologia me aproxima de Mauss (1974) quando cita que a resistência cultural é uma das formas de enfrentamento à homogeneização das forças de dominação.

Pensar processos de dominação especificamente das mulheres negras, é refletir como lembra bell hooks (1995, p. 477), sobre como “(...) a dominação e a opressão continuam a moldar as vidas de todos, sobretudo das pessoas negras e mestiças". Há uma produção cultural racista/sexista e anti-intelectual reafirmada constantemente, a partir de uma visão simbólica e materialmente construída nas sociedades capitalistas de supremacia patriarcal e branca.

O movimento da eugenia ganhou fôlego no final do Séc. XIX e disseminou em suas práticas a ideia da superioridade do conhecimento de matriz europeia, e da raça 77 Pensadores da temática da descolonização, como: Anibal QUIIJANO (2004), Edgardo LANDER (2007), Boaventura SANTOS (2007), entre outros branca. Pautou estratégias de dominação que impulsionou, no Brasil, a ideologia da supremacia dessa racionalidade deslegitimando outros saberes e práticas, ocasionando a substituição gradativa das parteiras. Estas foram aos poucos sendo substituídas por médicos e enfermeiras, uma disputa que naquele contexto, buscava a afirmação da medicina como prática, e que foi sendo consolidada na sociedade. Por sua vez, a sociedade reproduz a dominação cultural baseada nessa suposta superioridade, em detrimento de outros saberes das matrizes indígenas e africanas.

Assim, as relações sociais que estão presentes nas sociedades colonizadoras são fundadas a partir de um domínio branco-europeu, produzindo uma alienação colonial (FANON,1983), na qual o branco, sua cultura, seus saberes são universais.

\section{Saberes sob outro "Regime de Verdade"}

Na virada do Séc. XX, vemos surgir outros atores sociais, que vão se somar a essa disputa, são as parteiras estrangeiras formadas na Europa, que passaram a revalidar seus diplomas no Brasil. O que já demonstra o início de uma certa profissionalização do partejar (BESSA, 1999).

Com a criação das Maternidades, as parteiras estrangeiras puderam ser absorvidas nas instituições e, também, disputar espaços com outros profissionais da saúde: as enfermeiras. No entanto, ambas sob a autoridade médica, evidenciando uma limitação da atuação profissional nesses espaços, a tentativa de impor um controle sobre o ofício de parteira e uma hierarquia na assistência.

Trata-se da regulação do nascimento e dos corpos das mulheres por um dispositivo de saber/poder (FOUCAULT, 1986): o conhecimento médico baseado na razão e observação empírica que constrói um saber técnico sobre o parto.

A institucionalização do parto a partir das maternidades possibilitou a difusão de práticas médicas, na qual se misturavam os cuidados e recomendações aos filhos, para que fossem sadios e fortes, como necessitava a República (BESSA,1999). Progressivamente os conhecimentos tradicionais das mulheres parteiras e das comunidades vão sendo capturados pelo saber médico e, consequentemente, desqualificados.

A legitimação dos médicos e consequentemente a gradual deslegitimação das parteiras está posta. Vivenciamos no Brasil, no início do Séc. XX, a expansão 
do conhecimento científico, tanto nas ações preventivas quanto nas intervenções biomédicas, alinhadas aos ideais higienistas e Nacionalistas (BARRETO, 2011).

Surge ao longo do Séc. XX esse novo ator social: o(a) médico(a) que realiza partos. De 1931 até 1949 , os cursos de parto passaram a fazer parte da grade curricular dos cursos de medicina (GADERNAL et al, 2002). Mas, inicia-se já naquele momento uma tensão nesse campo com um movimento em algumas Escolas de Enfermagem, que criaram seus próprios cursos de parteiras.

Essa disputa levou a uma abertura profissional, sendo que nas Faculdades de Medicina nos anos subsequentes, passaram a oferecer o curso de parto como uma especialização. E em 1949 surgem os cursos de especialização na Faculdade de Enfermagem. Porém, para a realização desse curso se exigia o diploma de enfermagem, o que reafirma o ato do nascimento como "propriedade" dos especialistas (GADERNAL et al, 2002).

A Escola de Enfermagem passou a ser a instituição responsável para a capacitação formal de profissionais não-médicos para assistência ao nascimento e ao parto normal. Entidades médicas buscaram a normatização e o controle do ofício de partejar com a criação do curso para parteiras na Escola de Medicina do Rio de Janeiro, e com um movimento que dará início a uma tentativa de profissionalizar o ofício. Vale ressaltar que embora tenha sido criado tal curso, ele teve pouquíssima procura (BARRETO, 2011).

Naquele contexto, com a criação de uma rede de assistência maternainfantil defendida pelos especialistas, surge a medicalização do parto. A preocupação era proporcionar uma assistência às mães e crianças mais pobres da sociedade, que vai ter como expressão a criação da Maternidade de Laranjeiras no RJ. Nesta, catedráticos detentores do saber, expandiam seus conhecimentos na promoção de cuidados necessários às parturientes e bebês. O que, gradativamente, veio a deslegitimar os saberes tradicionais do ato de partejar (BARRETO, 2011).

No campo da saúde, e da medicina, refletir o quanto a universalização do conhecimento eurocêntrico impacta na produção e circulação de e conhecimentos e saberes diversos, torna-se fundamental.

Alice Lopes (1999) propõe uma análise do conhecimento tendo como base uma Perspectiva Pluralista e Descontinuísta da Cultura, por acreditar na sua contribuição para o entendimento dos diferentes saberes sociais. E a partir dessa perspectiva entendo que o cuidado em saúde está interligado à cultura, aos aspectos simbólicos e a visão de mundo dos sujeitos. $O$ que vai determinar a percepção do estado do doente, do diagnóstico e o tratamento. Ou seja, é um conhecimento que não pode ser imposto como uma única prática, visão e racionalidade, como se deu no processo de dominação implementado pelos colonizadores, e que se reproduz continuamente nas sociedades ocidentais. A Perspectiva Pluralista e Descontinuísta da Cultura questiona o modelo da razão ocidental que atua na uniformidade dos saberes. Nessa concepção pluralista, a cultura tem um caráter diverso, multifacetado (LOPES, 1999).

$\mathrm{Na}$ contemporaneidade o que se observa é a produção e reprodução de saberes para o controle da saúde reprodutiva baseados em um conhecimento etnocêntrico universalizante que passa a constituir regimes de verdades (FOUCAULT, 1986) e a intervir no cuidado das mulheres. Houve a transferência, para os especialistas-médicos, do protagonismo feminino nas decisões sobre o tipo de parto, o local e com qual profissional deve ser realizado. O que, por sua vez, passa a edificar modos excludentes e não equânimes quanto ao cuidado no sistema de saúde. De modo que são as mulheres negras e indígenas as que acabam vivenciando da forma mais perversa essa intervenção biomédica, por pertencerem aos grupos raciais historicamente alijados, sofrem em maior grau a regulação do Estado.

Não obstante, há conhecimentos e perspectivas epistemológicas que se mantêm vivas, como as matrizes indígenas e africanas presentes em comunidades tradicionais, que têm a potência de subverter a lógica eurocêntrica.

Considerações Finais

A desqualificação das práticas e saberes do partejar proveniente dos povos africanos e indígenas é produzida por um etnocentrismo universalizante, mas é possível observar resistência e discutir a sua preservação. Mesmo com a entrada maciça dos especialistas no evento do nascimento, o partejar em áreas rurais e em comunidades tradicionais, como quilombolas e indígenas, ainda persiste. Esse ofício é imbuído de um conhecimento baseado na experiência empírica e de um saber ancestral, passado através das gerações (TARGINO, 1992, OMS, 1992).

Os saberes das parteiras das comunidades tradicionais são legítimos, e coexistem com os modos convencionais de intervenções ao ato do 
nascimento nas sociedades ocidentais. Visibilizar a singularidade da prática de parteiras, resgatar e reconhecer a importância desse conhecimento oriundo de povos ancestrais, que fazem parte das matrizes culturais que constituem a sociedade brasileira, é subverter ao regime de verdade eurocêntrico sobre o partejar, é provocar a emergência de epistemologias que constituem as comunidades tradicionais.

Como cita Edgardo Lander (2001, p.23): “A descolonização do imaginário e a desuniversalização das formas coloniais do saber aparecem assim como condições de toda transformação". Acredita-se que é possível realizá-la a partir de uma desconstrução “(...) dos artefatos de legitimação e naturalização da hierarquização e exclusão social” (LANDER, 2001, p.23).

Ao afirmar a arte do partejar pelas mulheres de comunidades tradicionais, buscou-se a desestigmatização dos saberes e conhecimentos ancestrais de matriz indígena e africana.

Relativizar o conhecimento produzido nas sociedades de matriz europeia é resistir a um modelo de assistência que levou a um excesso de intervenções, cesárias e morbimortalidade materna e perinatal, que muitas vezes irão produzir violências contra as mulheres, em especial, a violência obstétrica.

Como ressalta (LOPES, 1999) devemos promover a pluralidade de saberes, os quais não devem ser construídos apenas pela ciência da modernidade, por não ser esta a única e possível forma de conhecer e compreender o mundo. O conhecimento é mais amplo, envolve também o saber cotidiano e empírico, o conhecimento ancestral de comunidades tradicionais. Esse reconhecimento é fundamental para a construção de uma sociedade intercultural.

\section{Referências}

BARRETO, Maria Renilda Nery. Pro Matre: arquivo e fontes para a história da maternidade no Rio de Janeiro. Hist. cienc. Saude-Manguinhos,vol.18, supl.1.Rio de Janeiro, dec. 2011.

BESSA, Lucineide Frota. Condições de trabalho de parteiras tradicionais: algumas características no contexto domiciliar rural. Rev. Esc. Enferm, USP, v.33, n.3, 1999.

FANON, Frantz. Pele negra, máscaras brancas. Salvador: Fator, 1983.

FOUCAULT, Michel. Arqueologia do Saber :Graal Ltda, 1986.

A ordem do Discurso. Edições Loyola, 1996.
GARDENAL, Carmen Lucia Cipullo, et al. Perfil das enfermeiras que atuam na assistência à gestante e puérpera, em instituições de Sorocaba/São Paulo (1999). Rev. Latino-Am.Enfermagem, v. 10, n. 4, p. 487-484, 2002

hooks, bell. Intelectuais Negras. Revista Estudos Feministas, Florianópolis, v.3, n.2, p 464-478, jan.1995.

LANDER, Edgardo. Ciencias sociales: saberes coloniales y eurocéntricos. In: Lander, Edgardo. (Comp.). La colonialidad del saber: eurocentrismo y ciencias sociales. Perspectivas Latinoamericanas. Buenos Aires: Clacso, 2001.

LANGDON, Jean. Matteson. Dau: Shamanic Power in Siona Religion and Medicine. In: LANGDON, Jean e BAER, Gerhard (orgs.). Matteson Portals of Power: Shamanism in South America. New Mexico, University of New Mexico Press, 1992. p. 41-62.

LEIBAN, Richard W. The Field of Medical Anthropology in J. Honigmann (org). Handbook of Social and Cultural Anthropology. Chicago, Rand MacNally. 1977. p. 1031-1072.

LOPES, Alice Ribeiro. Conhecimento escolar: ciência e cotidiano. Rio de Janeiro: EdUERJ,1999.

MAUSS, Marcel. As técnicas corporais. In: MAUSS, Marcel. Sociologia e antropologia. São Paulo: EPU, 1974. p. 209-233.

OLIVEIRA, Bárbara. Saberes Tradicionais. In: Educação Quilombola. Um Salto para o Futuro. Rio de Janeiro, Boletim 10, p.9-14, jun. 2007.

OMS. ORGANIZAÇÃO MUNDIAL DE SAÚDE. Parteiras leigas: uma declaração conjunta. Genebra: OMS/FNNAP/ UNICEF, 1992.

PINTO, Benedita Celeste De Morais. Vivências cotidianas de parteiras e 'experientes' do Tocantins. Revista Estudos Feministas: Florianópolis, v.10.n.2, p. 441-448, jan.2002.

QUIJANO, Aníbal. Dom Quixote e os moinhos de vento na América Latina. :Estudos Avançados, v.19, n.55, p. 09-31, 2005.

SANTOS, Boaventura de Sousa. A gramática do tempo. Para uma nova cultura política.2. ed. São Paulo: Cortez, 2006.

TARGINO, Roberto. Visão sócio-antropológica da parteira curiosa: dimensões pollticaeducativaterapeutica: rezas, ritos, ervas. Rio de Janeiro, Cultura Médica, 1992

ZOLLA, Carlos. Terapeutas, efermedades y recursos vegetables. Rev. México, n. 9, mar/abr.1986. 
DIÁlOGO COM BELL HOOKS: REORIENTAÇÃO DA FORMAÇÃO EM SAÚDE A PARTIR DA PERSPECTIVA NEGRA DECOLONIAL

\section{Dyana Helena de Souza}

Este ensaio é fruto da elaboração de um trabalho final da disciplina "Formação e Educação Permanente em Saúde", ofertada pelo Programa de PósGraduação em Saúde Coletiva da Universidade de Brasília (UNB), no primeiro semestre de 2019. A disciplina reuniu discentes de mestrado e doutorado e tinha como objetivos: a) contextualizar historicamente o marco legal da formação e educação permanente a partir do Sistema Único de Saúde (SUS), relacionando com a trajetória pessoal-profissional dos discentes; b) articular saberes e práticas educativas pautadas em abordagens problematizadoras e tecnologias centradas em metodologias ativas de ensino e aprendizagem aplicadas ao contexto da área da saúde; e, c) reconhecer as potencialidades da interprofissionalidade e ação colaborativa no trabalho em saúde com identificação de temas e cenários de aprendizagens para a concretização destes.

A disciplina utilizou abordagem fundamentada na "problematização de políticas e práticas de formação e educação permanente em saúde, com valorização da participação, do diálogo e inovação/criatividade dos estudantes" (GRIBOSKI et al, 2019, p.1), e como recursos pedagógicos as atividades desenvolvidas utilizaram análise de situações/casos reais, exposições orais, trabalhos e discussões em grupos e seminários de apresentação do trabalho final.

Para o trabalho final da disciplina foi construído um ensaio com objetivo de realizar um diálogo a partir do livro "Ensinando a transgredir: a educação como prática da liberdade" (hooks, 2013), e como ele pode contribuir para a reflexão sobre a reorientação da formação em saúde a partir da perspectiva negra decolonial.

Para apresentar a perspectiva negra decolonial, Nilma Lino Gomes (2018) faz algumas observações sobre como a colonialidade opera por meio dos currículos, e afirma que a descolonização dos mesmos não é tarefa fácil. Situa o atual contexto brasileiro, em que são defendidos projetos e iniciativas como o Programa Escola Sem partido, a Reforma do Ensino Médio, e a proibição da discussão sobre igualdade de gênero e sexualidade na escola. Esses são alguns exemplos que a autora traz para debater sobre como descolonizar os currículos é um "desafio para a construção da democracia e para a luta antirracista" (GOMES, 2018, p.231). A autora enfatiza a perspectiva negra decolonial e a necessidade de reconhecimento destes sujeitos como produtores de conhecimento. Nilma Lino Gomes (2018) explica ainda o que seria essa perspectiva negra decolonial e a importância do Movimento Negro no âmbito brasileiro, conforme a seguir:

A perspectiva negra decolonial brasileira é a que busca e coloca outras narrativas no campo do conhecimento e do currículo, que dá legitimidade aos saberes acadêmicos, políticos, identitários e estéticocorpóreos negros. É aquela que dá relevância aos saberes e às práticas afro-brasileiras emaranhadas em todos nós, inclusive nas pessoas brancas, nos vários grupos de imigrantes e seus descendentes e nos povos indígenas brasileiros. [...] Essa perspectiva considera o Movimento Negro Brasileiro como um produtor e sistematizador de saberes. É a que tem como característica especial o fato de os sujeitos que a produzem nunca se esquecerem do que o processo colonial fez com seus ancestrais e do que a colonialidade ainda faz consigo (GOMES, 2018, p.245).

Considerando a população negra como sujeito que constrói suas próprias histórias, a autora do presente ensaio é uma mulher negra que habita o espaço universitário desde a formação na graduação em Saúde Coletiva (2014) e em Serviço Social (2018), concluídas na Universidade de Brasília (UNB), e que tem se preocupado com a forma na qual a universidade tem reproduzido um pensamento e ensino colonizados. Com essas inquietações, que se estendem no âmbito do mestrado, a pesquisa desenvolvida tem indagado como a equidade racial está inserida na formação profissional nos cursos da área de saúde.

A partir da análise das Diretrizes Curriculares Nacionais (DCN) e dos Projetos Políticos Pedagógicos dos Cursos (PPC) de Saúde Coletiva, Enfermagem e Medicina da Universidade de Brasília, Dais Rocha, Dyana Souza e Edu Cavadinha (2019) verificaram que estes atendem aos preceitos legais referentes à educação para as relações étnico-raciais nos cursos, o que impulsionou a necessidade de aprofundamento de como essa inserção tem ocorrido no cotidiano desses cursos de graduação. Os autores ressaltaram que quando há apenas a mera inclusão conceitual da equidade nas DCN, não significa que de fato ela será implementada 
na formação, e "reconhecer a centralidade do debate sobre equidade constitui possibilidade de mudanças no processo de ensino-aprendizagem como se conhece atualmente" (ROCHA; SOUZA; CAVADINHA, 2019, p.10).

Focando especificamente na equidade racial negra e na educação das relações étnico-raciais nos cursos de saúde, Rebecca Santana et al. (2019, p.1) entrevistaram coordenadores de cursos da saúde em três universidades de São Paulo para discutir "a prática da implementação da Política Nacional de Saúde Integral para a População negra (...) problematizando a presença da temática "equidade racial em Saúde" no cotidiano das instituições".

Os resultados da pesquisa apontaram que: a produção sobre a saúde integral da população negra ainda encontra dificuldades de consolidação no currículo dos cursos de formação em saúde; que quando a temática é encontrada, ela ainda tem sido vista de forma "tímida"; que houve mais destaque para a "imposição" desta discussão feita pelo Ministério da Educação (MEC), do que para a sua importância no âmbito de inserção dos currículos; que a universalidade e igualdade estão presentes nos depoimentos analisados, mas os coordenadores de cursos entrevistados "ignoram ou não compreendem profundamente as referências acerca do reconhecimento da diferença que há desconhecimento da produção bibliográfica sobre equidade-iniquidade racial em saúde; e um efeito desse desconhecimento é a "invisibilidade do racismo como um determinante social de saúde” (SANTANA et al, 2019, p.12).

A Política Nacional de Saúde Integral da População Negra (BRASIL, 2009, p.37) enfatizou a necessidade da inclusão dos "temas Racismo e Saúde da População Negra nos processos de educação permanente dos trabalhadores da saúde", e ainda, que a política esteja em articulação com a Política Nacional de Educação Permanente em Saúde. Mas como pensar nessa articulação, considerando o Racismo Institucional e seus impactos no SUS? Para auxiliar essa articulação é importante considerar as orientações das Diretrizes Curriculares Nacionais para a Educação das Relações Étnico-Raciais e para o Ensino de História e Cultura AfroBrasileira e Africana (BRASIL, 2004a), que situam a configuração do racismo e do epistemicídio no âmbito político, cultural e pedagógico da sociedade. Para este ensaio o âmbito pedagógico foi explorado a partir das contribuições da autora estadunidense bell hooks.
Reorientação da Formação em Saúde: Contestando o Modelo Tradicional de Ensino

Henrique Dias, Luciana Lima e Márcia Teixeira (2013, p.1613) analisaram o histórico da "política nacional de reorientação da formação profissional em saúde desenvolvida a partir de 2003, e seus antecedentes", e apresentaram algumas iniciativas que impulsionaram essa trajetória, como o Programa de Integração Docentes Assistencial (IDA), criado em 1981; o Projeto Uma Nova Iniciativa (UNI), no início dos anos 1990; e, o Programa Nacional de Incentivo a Mudanças Curriculares nos Cursos de Medicina (PROMED), no início dos anos 2000.

Em 2003 houve a criação da Secretaria de Gestão do Trabalho e Educação Permanente na Saúde (SGTES), procurando uma maior aproximação entre as instituições de ensino e o sistema de saúde. Ganharam destaque o Projeto Vivência e Estágios na Realidade do SUS (VER-SUS); e o APRENDER-SUS. Em 2005, houve a criação do Programa Nacional de Reorientação da Formação Profissional em Saúde (Pró-Saúde I), abarcando inicialmente os cursos de Enfermagem, Medicina e Odontologia, e era financiado pelo Ministério da Saúde. De acordo com os autores:

Esperava-se a substituição do modelo de formação - individual, de caráter fortemente especialista e hospitalocêntrico - para um processo formativo que levasse em conta os aspectos socioeconômicos e culturais da população. Preconizava-se a articulação com o sistema público de saúde por meio de ações de promoção da saúde e prevenção de agravos; da difusão da educação profissional como um processo permanente; da busca pelo equilíbrio entre a excelência técnica e os fatores de ordem social; e das mudanças no desenvolvimento das pesquisas em saúde em prol do SUS (DIAS; LIMA; TEIXEIRA, 2013, p.1617).

Com o Pró-Saúde II, em 2007, houve ampliação para os demais cursos da área de saúde. No mesmo ano foi criado o Programa de Educação para o Trabalho (Pet-Saúde), com fortalecimento da parceria entre os ministérios da Saúde e Educação, que tinha como foco a "qualificação de estudantes de graduação e de pós-graduação, na rede de serviços, por meio de vivências estágios, iniciação ao trabalho e programas de aperfeiçoamento e especialização (DIAS; LIMA; TEIXEIRA, 2013, p.1618)". 
Essas experiências de reorientação da formação para o SUS foram e estão sendo centrais para qualificar a integração ensino-serviço-comunidade como destacado. A nova versão do PET-Saúde, por exemplo, ao focar na interprofissionalidade tem visado uma educação "em direção a uma prática mais colaborativa, conforme as necessidades do nosso sistema de saúde” (BRASIL, 2018).

Considerando estes aspectos iniciais, Ricardo Ceccim e Laura Feuerwerker (2004) ressaltaram a necessidade de que a formação em saúde extrapole o modelo técnico-científico e conservador, pois ele tem restringindo uma concepção ampliada da saúde pautada nos princípios e diretrizes do SUS. Os autores fizeram crítica à formação para a saúde que temos feito no Brasil e colocaram a urgente reforma que deve acontecer na educação e como o SUS tem papel ativo nesse processo de reorientação.

Assim, como Henrique Dias, Luciana Lima e Márcia Teixeira (2013), Ricardo Ceccim e Laura Feuerwerker (2004) destacaram a criação de iniciativas como: "Interiorização do Trabalho em Saúde (Pits), de Incentivo às Mudanças Curriculares nos Cursos de Medicina (Promed), de Capacitação e Formação em Saúde da Família, de Profissionalização dos Trabalhadores da Área da Enfermagem (Profae)", mas colocaram que elas foram tímidas na capacidade de promover mudanças nas práticas dominantes. Mas como seria possível uma articulação de novas estratégias para romper com essa lógica historicamente estabelecida? Para começar a instigar, os autores sinalizam que:

Uma proposta de ação estratégica para transformar a organização dos serviços e dos processos formativos, as práticas de saúde e as práticas pedagógicas implicaria trabalho articulado entre o sistema de saúde (em suas várias esferas de gestão) e as instituições formadoras. Colocaria em evidência a formação para a área da saúde como construção da educação em serviço/educação permanente em saúde: agregação entre desenvolvimento individual e institucional, entre serviços e gestão setorial e entre atenção à saúde e controle social (CECCIM; FEUERWERKER, 2004, p.45).

Os autores apresentaram o quadrilátero da formação para a área da saúde como sendo a articulação entre: ensino-gestão-atenção-controle social. A ideia do quadrilátero da formação aparece justamente para quebrar a ideia de um processo de ensino hierarquizado e verticalizado.
A imagem do quadrilátero da formação para a área da saúde - ensino/ gestão setorial / práticas de atenção / controle social - propõe construir e organizar uma educação responsável por processos interativos e de ação na realidade para operar mudanças (desejo de futuro), mobilizar caminhos (negociar e pactuar processos), convocar protagonismos (pedagogia in acto) e detectar a paisagem interativa e móvel de indivíduos, coletivos e instituições, como cenário de conhecimentos e invenções (cartografia permanente). No quadrilátero estão aspectos éticos, estéticos, tecnológicos e organizacionais, operando em correspondência, agenciando atos permanentemente reavaliados e contextualizados (CECCIM; FEUERWERKER, 2004, p.59).

Tendo em vista a complexidade do trabalho em saúde e o desafio de se pensar a nova lógica que o quadrilátero apresenta, os autores pensam o papel da educação permanente nesse contexto. Ela é:

[...] parte do pressuposto da aprendizagem significativa (que promove e produz sentidos) e propõe que a transformação das práticas profissionais deva estar baseada na reflexão crítica sobre as práticas reais de profissionais e em ação na rede de serviços (CECCEM; FEUERWERKER, 2004, p.49).

A educação permanente necessita do espaço de aprendizagem vivo no cotidiano dos serviços!

Uma formação, assim colocada, envolve a mudança das estratégias de organização e do exercício da atenção, que passam a ser problematizadas na prática concreta dos profissionais em terreno e dos quadros dirigentes. As demandas para educação em serviço não se definem somente a partir de uma lista de necessidades individuais de atualização, nem das orientações dos níveis centrais, mas prioritariamente a partir dos problemas da organização do trabalho, considerando a necessidade de prestar atenção relevante e de qualidade, com integralidade e humanização, e considerando ainda a necessidade de conduzir ações, serviços e sistemas com produção em rede e solidariedade intersetorial. É a partir da problematização do processo e da qualidade do trabalho - em cada serviço de saúde - que são identificadas as necessidades de qualificação, garantindo a aplicabilidade e a relevância dos conteúdos e tecnologias estabelecidas (CECCIM; FEUERWERKER, 2004, p.50). 
Falar sobre a educação permanente em saúde exige um exercício de repensar os atores, os territórios e os papeis que são tradicionalmente atribuídos a eles. Ou seja, formação é movimento, é ação, e necessita de conexão, como afirma Ricardo Ceccim (2018, p. 1747) "por conexão com o andar do trabalho e pela não segregação entre espaço da formação e espaço do trabalho".

Outra discussão que também tem sido feita quando pensamos a reorientação da formação em saúde é a contribuição das metodologias ativas, como ressalta Neusi Berbel (2011) quando fala sobre novas propostas pedagógicas a partir da inserção dessas metodologias na formação.

Tomando como inspiração as contribuições do educador Paulo Freire para a defesa das metodologias ativas com a educação de jovens e adultos, e considerando que todos contribuem no processo de aprendizagem a partir de conhecimentos prévios e de suas experiências, Neusi Berbel (2011) considera nas metodologias ativas uma nova lógica a partir da relação professor-aluno. O professor "atua como facilitador ou orientador, para que o estudante faça pesquisas, reflita e decida por ele mesmo, o que fazer para atingir seus objetivos estabelecidos (BERBEL, 2011, p.29)" e para isso, necessita de uma "nova postura pedagógica de seus professores com características diferenciadas daquelas de controle” (BERBEL, 2011, p.30).

Para Neusi Berbel (2011, p.29), as metodologias ativas:

[...] baseiam-se em formas de desenvolver o processo de aprender, utilizando experiências reais ou simuladas, visando às condições de solucionar, com sucesso, desafios advindos das atividades essenciais da prática social, em diferentes contextos.

A autora apresenta algumas metodologias ao longo do artigo, como o Estudo de Casos; o Processo do Incidente; o Método de Projetos; a Aprendizagem Baseada em Problemas, e a Metodologia de Problematização (Arco de Maguerez).

Diálogo com bell hooks - “Ensinando a Transgredir: a Edu cação como Prática de Liberdade"

Há cerca de quatro ou cinco anos tenho conhecido e me aproximado de histórias sobre a vida e obra de mulheres negras, e Glória Watkins é uma dessas mulheres. Ela é conhecida por utilizar o pseudônimo "bell hooks", o adotando como forma de ato político e empoderamento, além de ser uma homenagem aos sobrenomes de sua mãe e avó. A autora afirma que reivindicar esse nome é ligar a própria voz a um legado ancestral de mulheres falando para uma mulher de poder (RIBEIRO, 2013). Sendo assim, ao longo deste ensaio será adotado o nome que a autora utiliza: bell hooks.

bell hooks, mulher negra, nasceu em 1952 em Hopkinsville, cidade na zona rural do Estados Unidos, durante o período de segregação racial. Formada em literatura pela Universidade de Stanford, fez mestrado na Universidade de Wisconsin e doutorado na Universidade da Califórnia. É uma importante intelectual, teórica feminista, crítica cultural e autora de mais de 30 livros. Têm publicações de diferentes gêneros, como críticas culturais, memórias pessoais, poesias e livros infantis. Suas obras abordam os temas de gênero, raça, classe, espiritualidade e ensino (bell hooks Intitute).

bell hooks (2013) inicia o livro "Ensinando a Transgredir: educação como prática de liberdade" contando sobre seu sentimento ao ser efetivada no departamento de Inglês do Oberlin College, na Califórnia. O medo de que a autora fala, era o medo de "ficar presa na academia para sempre" (hooks, 2013, p.9). De um lado, ela coloca que desde criança estava destinada a ser professora, mas, de outro, sempre teve o sonho de ser escritora. Suas influências estavam nas escolas frequentadas somente por professoras e alunos negros, quando teve a experiência do aprendizado como revolução. Na escola, o compromisso da maioria das professoras era incentivar aos alunos, afirmando sempre que eles poderiam ser o que quisessem, e segundo hooks (2013, p. 10) "aprendemos desde cedo que nossa devoção ao estudo, à vida ao intelecto, era um ato contra-hegemônico, um modo de resistir a todas as estratégias brancas de colonização racista”. E chama a esse incentivo de pedagogia revolucionária de resistência anticolonial.

Após a integração racial, a escola mudou radicalmente: o conhecimento passou a se resumir à pura informação. Não tinha relação com o modo de viver e se comportar. Já não "tinha ligação com a luta antirracista (hooks, 2013, p.12)". Se na sua escola de origem os professores tinham um compromisso político para educar, na nova escola, os professores brancos reforçavam os estereótipos racistas. De um lado uma escola que trabalha com a educação como prática de liberdade, de outro, uma escola que trabalha para reforçar a dominação. Como são nossas escolas e universidades atualmente? Precisamos pensar... 
A partir do momento que bell hooks ingressou na Universidade de Stanford, ficou encantada com a possibilidade de se tornar uma intelectual negra. A universidade também assustou: ali não parecia que a noção de educação como prática da liberdade estava presente, pois a universidade parecia uma prisão! Apesar do susto, que continuou durante a pós-graduação, ela continuava lutando para "reivindicar e conservar o direito de ser uma pensadora independente" (hooks, 2013, p.13). Ainda na busca de refletir sobre como o ensino e o aprendizado poderiam ser diferentes, bell hooks descobre a obra de Paulo Freire:

\begin{abstract}
Quando descobri a obra do pensador brasileiro Paulo Freire, meu primeiro contato com a pedagogia crítica, encontrei nele um mentor e um guia, alguém que entendia que o aprendizado poderia ser libertador. Com os ensinamentos dele e minha crescente compreensão de como a educação que eu recebera nas escolas exclusivamente negras do Sul havia me fortalecido, comecei a desenvolver um modelo para minha prática pedagógica. Já profundamente engajada no pensamento feminista, não tive dificuldade em aplicar essa crítica à obra de Paulo Freire. Significativamente, eu sentia que esse mentor e guia, que eu nunca vira pessoalmente, estimularia e apoiaria minha contestação às suas ideias se fosse realmente comprometido com a educação como prática de liberdade. Ao mesmo tempo, eu usava seus paradigmas pedagógicos para criticar as limitações das salas de aula feministas (hooks, 2013, p.15).
\end{abstract}

Nessas reflexões iniciais, a autora coloca como foi dar sua primeira aula em um curso de graduação e como se inspirou nas professoras negras que teve, na obra de Paulo Freire (que se reconhecia na posição de homem branco) e no pensamento feminista sobre a pedagogia radical. Ela reconhece que o campo acadêmico, no que se refere à pedagogia e crítica e/ou pedagogia feminista, tem tido um "discurso feito e ouvido por homens e mulheres brancos (hooks, 2013, p.20)". E ressalta que é recente que a pedagogia radical, a perspectiva crítica e feminista, tem reconhecido as diferenças, seja por classe social, raça, ou orientação sexual (hooks, 2013).

No livro, hooks (2013, p. 20) procura "partilhar ideias, estratégias e reflexões sobre a prática crítica pedagógica”, e assim, busca fazer uma intervenção contrária à desvalorização do professor, pensando a necessidade urgente de mudar as práticas de ensino, pois, a educação está numa grave crise!
A educação como prática de liberdade é um jeito de ensinar, mostrando que qualquer um pode aprender. A autora sempre destaca o papel de professores "que tiveram coragem de transgredir as fronteiras (hooks, 2013, p.25)" em sua vida. Inspirada por Freire, ela pensa as salas de aula como cenários em que os alunos são participantes ativos e não consumidores passivos.

A obra de Freire afirmava que a educação só pode ser libertadora quando todos tomam posse do conhecimento como se este fosse uma plantação em que todos temos de trabalhar. Essa noção de trabalho coletivo também é afirmada pela filosofia do budismo engajado de Thich Nhat Hanh, focada na prática associada à contemplação. Sua filosofia é semelhante à de Freire na "práxis" - agir e refletir sobre o mundo a fim de modifica-lo (hooks, 2013, p.26).

Quando estudou com Paulo Freire, bell hooks (2013, p.31) pôde conhecer "o modo com que sua maneira de ensinar exemplificava sua teoria pedagógica", e como na educação a partir da prática da liberdade, professor e aluno são fortalecidos a partir de um modelo holístico de aprendizado: "totalmente presentes em mente, corpo e espírito" (hooks, 2013, p.36). Esses professores que trabalham na perspectiva de transformar o currículo têm sido os "mais dispostos a correr os riscos acarretados pela pedagogia engajada e a fazer de sua prática de ensino um foco de resistência" (hooks, 2013, p.36), e isso é possível quando abraçam o desafio da autoatualização.

Outro ponto que bell hooks (2013) menciona, é que ela está ciente que vivemos em uma cultura de dominação, mas coloca a seguinte questão: "Quais os valores e hábitos de ser refletem meu/nosso compromisso com a liberdade?” Em sua caminhada percebeu que muitos se dizem comprometidos com a liberdade e com a justiça para todos, mas no cotidiano do seu modo de vida, valores e hábitos, mantêm a cultura de dominação. Embora alguns achem que apoiar a diversidade cultural significa substituir uma "ditadura do conhecimento por outra" (hooks, 2013, p.49), ela afirma que essa é uma percepção errônea da diversidade cultural. O sistemamundo capitalista/patriarcal/cristão/moderno/colonial europeu (BERNARDINOCOSTA; GROSFOGUEL, 2016) mantém a cultura da dominação promovendo vícios de mentira e de negação, sendo um dos principais motivos "porque não sofremos uma revolução de valores" (hooks, 2013, p.44). 
Ela traz o exemplo de uma mentira aparentemente inocente, mas que é muito difundida: "muitos brancos (e até negros) afirmam que o racismo não existe mais e que sólidas oportunidades de igualdade social atualmente existentes habilitam qualquer negro trabalhador a alcançar autossuficiência econômica" (hooks, 2013, p.44). Essas inverdades chegam a tal ponto de serem estrategicamente comunicadas de modo eficaz. Outro exemplo é a forma do papel tradicional da universidade na busca da verdade e na partilha de conhecimento e informação: "ficará claro, infelizmente que as parcialidades que sustentam a supremacia branca, o imperialismo, o sexismo e o racismo distorcem a educação a tal ponto que ela deixou de ser uma prática da liberdade" (hooks, 2013, p.45).

Diante dos desafios para criar uma academia culturalmente diversa, hooks (2013) coloca que temos que nos comprometer inteiramente; aprender com outros movimentos de mudança; temos que aceitar que a luta será longa e que temos que permanecer pacientes e vigilantes. Sobre essa questão, a autora reconhece que o multiculturalismo eque seu reconhecimento está em foco na sociedade, eprincipalmente na educação, mas ainda não são discussões práticas suficientes sobre "como o contexto da sala de aula pode ser transformado de modo a fazer o aprendizado uma experiência de inclusão" (hooks, 2013, p.51). Sendo assim, ela afirma que precisamos mudar o nosso estilo de ensino! E expõe os desafios quando começou a dar aulas, pois ela própria não estava preparada para lidar com a diferença multicultural e étnica que havia em sala de aula, exemplificando como trabalhou estratégias de ensino para abrir espaço a um aprendizado multicultural (hooks, 2013).

A educação multicultural e suas implicações políticas assustam a todos. Com relação aos professores, a autora propõe que os educadores precisam de locais de formação para expressar esses medos e "aprender a criar estratégias para abordar a sala de aula e o currículo multiculturais" (hooks, 2013, p.52). É necessário abordar um ensino com consciência crítica de raça, de sexo e de classe social: a sala de aula deve ser um contexto democrático "onde todos sintam a responsabilidade de contribuir” (hooks, 2013, p.56), esse é um objetivo central da pedagogia transformadora.

Deve-se criar um espaço de comunidade em que haja um bem comum que una a todos. Mas qual seria esse bem comum? Para bell hooks (2013), ele é o bem de aprender. O exercício de ouvir um ao outro é essencial para esse novo contexto, que é um desafio, pois leva tempo para mudar de paradigma e partilhar o conhecimento, principalmente considerando a forma tradicional como somos "ensinados".

Em um capítulo específico no qual fala sobre sua relação com Paulo Freire, a autora relata que foi em um momento de sua vida em que questionava a política de dominação que "ele me fez pensar sobre a construção de uma identidade na resistência” (hooks, 2013, p.66), assim, fala sobre o processo de descolonização e conscientização. Pensando as lutas pela libertação, há uma espécie de estágio inicial da transformação, "aquele momento histórico em que começamos a pensar criticamente sobre nós mesmas e nossa identidade diante das nossas circunstâncias políticas" (hooks, 2013, p.67), e esse entendimento tem sido mal compreendido, como afirma. Algumas leituras têm apontado para uma direção, como se fosse "suficiente que os indivíduos mudem sua forma de pensar", mas essa visão que "não transmite entendimento profundo de o quanto uma mudança de atitude (e não somente o término de qualquer processo transformador) pode ser significativa para um povo oprimido/colonizado" (hooks, 2013, p.68):

Repetidamente, Freire tem de lembrar os leitores de que ele nunca falou da conscientização como um fim em sim, mas sempre na medida em que se forme a uma práxis significativa. Gosto quando ele fala da necessidade de tornar real na prática o que já sabemos na consciência (hooks, 2013, p.68).

A autora retoma como sua experiência de mulher negra que cresceu em um contexto político difícil para a vida dos negros no sul dos Estados Unidos, e como a ênfase da educação como prática libertadora a fizeram conectar-se com Paulo Freire. bell hooks (2013, p.75) relaciona também a ligação entre a obra de Freire e o desenvolvimento da sua obra de teoria feminista e crítica social, pois a partir da crítica ao movimento feminista que invisibilizava as mulheres negras, ela pôde afirmar "seu direito, como sujeito de resistência".

bell hooks (hooks, 2013, p.175) fala sobre a prática do diálogo como um dos meios mais simples que temos para cruzar as fronteiras e as barreiras de "uma atmosfera cultural em que os preconceitos possam ser questionados e modificados".

A autora não deixa de colocar que "o compromisso profundo com a pedagogia engajada é cansativo para o espírito" (hooks, 2013, p.267), mas que esse compromisso é uma expressão de ativismo político. Ela traz a expressão de nadar 
contra a corrente, principalmente em contextos de desvalorização do ensino nas ocupações profissionais. Ela coloca sua tristeza de que professores que têm um compromisso com a pedagogia engajada são questionados por pessoas que pensam que "o que fazemos não é tão rigorosamente acadêmico quanto deveria ser" (hooks, 2013, p.268). Essa pedagogia engajada a impele de ser criativa em sala de aula, mas também fora desse cenário. A autora termina por fim, com a seguinte reflexão:

A academia não é o paraíso. Mas o aprendizado é um lugar onde o paraíso pode ser criado. A sala de aula, com todas as suas limitações, continua sendo um ambiente de possibilidades. Nesse campo de possibilidades temos a oportunidade de trabalhar pela liberdade, de exigir de nós e dos nossos camaradas uma abertura da mente e do coração que nos permita encarar a realidade ao mesmo tempo em que, coletivamente, imaginamos esquemas para cruzar fronteiras, para transgredir. Isso é a educação como prática de liberdade (hooks, 2013, p.273).

Para Finalizar o Diálogo, Ou Para Gerar Mais Diálogos e Inspirações...

Pensar a reorientação da formação em saúde exige a compreensão de como o epistemicídio (CARNEIRO, 2005) e a colonialidade do poder, do ser e do saber (BERNARDINO-COSTA; GROSFOGUEL, 2016) estruturam a universidade. Com relação à colonialidade do saber, Castro-Gómez (2007) fala sobre o ensino nas universidades e como nelas está presente a "herança colonial", reforçando a dominação cultural, econômica e política. Trazendo assim, a discussão sobre o paradigma do pensamento complexo em que todos nós somos um todo "físicoquímico-biológico-psicológico-social-cultural” integrado no universo.

O paradigma da complexidade poderia ser benéfico na medida em que promove a transdisciplinaridade. É com esse pensamento que vivemos em um mundo que não pode ser entendido de forma compartimentada e fragmentada, mas ainda assim, a universidade tem realizado essas análises e formado profissionais com estas características, e quando pensamos nas formações em saúde, estas observações tornam-se mais evidentes. Para evitar essa fragmentação, a transdisciplinaridade poderia ser utilizada para repensar tais práticas e promover uma universidade transcultural: na qual diferentes formas culturais de produção de conhecimentos possam conviver sem serem submetidas a uma hegemonia da episteme da ciência ocidental (CASTRO-GÓMEZ, 2007). O autor pensa que não se trata apenas da possibilidade de articulação de uma disciplina com o conhecimento de outra, gerando novos campos de saber. O que deve ser levado em consideração, e que é um dos mais difíceis, é como diferentes formas culturais de conhecimento podem conviver em um espaço universitário. Esse diálogo de saberes só é possível com a descolonização do conhecimento e das instituições de ensino.

O que bell hooks(2013) apresenta, como a prática do diálogo para exercício da educação multicultural, pode ser mais aprofundado na leitura de Castro-Gomez (2007), quando este autor fala sobre a educação transcultural. A formação que considera o diálogo de saberes, favorece o reconhecimento das experiências que os estudantes já trazem para a formação.

As referências sobre reorientação da formação em saúde mostraram a urgência de extrapolarmos um ensino conservador focado no modelo técnico-científico, e ressaltam como a educação permanente é essencial no processo. Nesse contexto, a contribuição de bell hooks nos faz refletir sobre essa formação e sobre a perspectiva de criação de espaços para a valorização dos saberes da população negra e sua realidade.

bell hooks nos provoca a todo o momento sobre como a universidade tem parecido uma prisão, e traz exemplos de que é possível construir uma nova forma de aprendizado. Seu diálogo com Paulo Freire, nos ajuda a pensar como as metodologias ativas são potências e podem ser inseridas na prática, e ainda, como o ensino vai além da sala de aula: por isso é necessária uma articulação de ensino-serviço-comunidade.

\section{Referências}

bell hooks Intitute. Disponível em: <http://www.bellhooksinstitute.com/> Acesso em: 25 mai. 2019.

BERBEL, Neusi Aparecisa Navas. As metodologias ativas e a promoção da autonomia de estudantes. Ciências Sociais e Humanas, Londrina, v. 32, n. 1, p. 25-40, jan./jun. 2011. Disponível em: <http://www.scielo.br/ pdf/icse/v2n2/08.pdf $>$. Acesso em: 25 mai. 2019.

BERNARDINO-COSTA, Joaze; GROSFOGUEL, Ramón. Decolonialidade e perspectiva negra. Sociedade e Estado, v.31, n 1, jan./abr. 2016.

BRASIL. Ministério da Educação. Diretrizes Curriculares Nacionais para a Educação das Relações ÉtnicoRaciais e para o Ensino de História e Cultura Afro-Brasileira e Africana. Braślia: Conselho Nacional de Educação/Ministério da Educação, 2004a. Disponível em: <http://portal.mec.gov.br/cne>. Acesso em: 25 mai. 2019.

BRASIL. Ministério da Saúde. Portaria no $\mathbf{n}^{\mathbf{9}}$ 992, de 13 de maio de 2009. Institui a Política Nacional de Saúde Integral da População Negra. Brasília, DF, 2009. 
BRASIL. Ministério da Saúde. Portaria no 198 GM/MS de 13 de fevereiro de 2004b. Institui a Política Nacional de Educação Permanente em Saúde como estratégia do Sistema Único de Saúde para a formação e o desenvivino de trab desenvalvino Perto de trablhar Drocoes/pacto saude_volume9.pdf>. Acesso em: 25 mai. 2019

BRASIL. Ministério da Saúde. PET-Saúde abre inscrições para projetos. 2018. Disponível em <http://portalms. saude.gov.br/noticias/sgtes/43908-pet-saude-abre-inscricoes-para-projetos>. Acesso em: 25 mai. 2019

CARNEIRO, Aparecida Sueli. A construção do outro como não-ser como fundamento do ser. 2005. Tese (Doutorado em Educação) - Universidade de São Paulo, São Paulo, 2005.

CASTANHO, Maria Eugênia. Sobre professores marcantes. In: CASTANHO, Sérgio; CASTANHO, Maria Eugênia. (Orgs.). Temas e textos em metodologia do ensino superior. Campinas: Papirus, 2001. p. 153-163.

CASTRO-GÓMEZ, Santiago. Descolonizar la universidad. La hybris del punto cero y el diálogo de saberes. En: CASTROGÓMEZ, Santiago; GROSFOGUEL, Ramón (Eds.). El giro decolonial: reflexiones para uma diversidad epistêmica más allá del capitalismo global. Bogotá: Siglo del Hombre Editores. 2007. p. 79-91. Disponivel em: <http://www.ramwan.net/restrepo/decolonial/14-castro-descolonizar\%201a\%20universidad.pdf $>$. Acesso em: 25 mai. 2019

CECCIM, Ricardo Burg. Conexões e fronteiras da interprofissionalidade: forma e formação. Interface comunicação, saúde, educação, Botucatu, v.22, supl. 2, p. 1739-49, 2018. Disponível em: <http://www.scielo. $\mathrm{br} / \mathrm{pdf} / \mathrm{icse} / \mathrm{v} 22 \mathrm{~s} 2 / 1807-5762$-icse-22-s2-1739.pdf>. Acesso em: 25 mai. 2019.

CECCIM, Ricardo Burg. Educação permanente em saúde: desafio ambicioso e necessário. Interface: comunicação, saúde educação, Botucatu, v. 9, n. 16, p. 161-77, set.2004/fev.2005. Disponível em: 〈http://www.escoladesaude.pr.gov.br/arquivos/ educação, Botucatu, v. 9, n. 16, p. 161-77, set.2004/fev.2005. Disponivel

CECCIM, Ricardo Burg; FEUERWERKER, Laura C.M. O Quadrilátero da Formação para a Área da Saúde: Ensino, Gestão, Atenção e Controle Social. Rev. Saúde Coletiva, Rio de Janeiro, v. 14, n. 1, p.41- 65, 2004. Disponível em: <http://www. scielo.br/pdf/physis/v14n1/v14nla04.pdf $>$. Acesso em: 25 mai. 2019.

DIAS Henrique Sant'Anna; LIMA Luciana Dias de; TEIXEIRA, Márcia. A trajetória da política nacional de reorientação da formação profissional em saúde no SUS. Ciência \& Saúde Coletiva, v. 18, n. 6, p. 1613-1624, 2013. Disponível em: <https://www.scielosp.org/article/ssm/content/raw/?resource_ssm_path=/media/ assets/csc/v18n6/13 pdf>. Acesso em: 25 mai. 2019.

GOMES, Nilma Lino. O Movimento Negro e a intelectualidade negra descolonizando os currículos. In: BERNARDINOCOSTA, Joaze; MALDONADO-TORRES, Nelson; GROSGOGUEL, Ramón.(Orgs.).Decolonialidadee pensament afrodiaspórico. Belo Horizonte: Autêntica Editora, 2018. p. 223-246 (Coleção Cultura Negra e Identidades).

hooks, bell. Ensinando a transgredir: a educação como prática da liberdade. Tradução de Marcelo Brandão Cipolla. São Paulo: Martins Fontes, 2013

RIBEIRO, Alan Augusto Moraes. Blackness: identidades, racismo e masculinidades em bell hooks. In: Seminário Internacional Fazendo Gênero, 10., 2013, Florianópolis. Anais Eletrônicos [...]. Florianópolis, 2013. Disponível em: <https://www.kilombagem.net.br/wp-content/uploads/2015/07/Alan-augusto-bell-hooksmasculinidade-.pdf $>$. Acesso em: 25 mai. 2019.

ROCHA, Dais Gonçalves; SOUZA, Dyana Helena de; CAVADINHA, Edu. Equidade nos cursos de graduação em Saúde marco legal, desafios políticos e metodológicos. Interface: comunicação, saúde, educação, Botucatu, v.23, 2019. Disponível em: <http://www.scielo.br/scielo.php?script=sci_abstract\&pid=S1414-32832019000100216\&lng=en\&n $\mathrm{rm}=$ iso\&tlng=pt $>$. Acesso em: 25 mai. 2019

SANTANA Rebecca Alethéia Ribeiro; AKERMAN, Marco; FAUSTINO, Deivison Mendes; SPIASSI, Ana Lucia; GUERRIERO, Iara Coelho Zito. A equidade racial e a educação das relações étnico-raciais nos cursos de Saúde. Interface: comunicação, saúde, educação, Botucatu, v.23, 2019. Disponível em: <http://www.scielo.br/scielo.php?script=sci_ abstract\&pid=S141432832019000100208\&lng=pt\&nrm=iso $>$. Acesso em: 25 mai. 2019.
AbAIXA A GUARDA E ABRE O PEITO: O RESGATE FÍSICO, cognitivo e subjetivo do sujeito negro no Slam Chamego

Fernanda Maiato Maíne Alves

Rafael Barcellos

“Os pretos estão se amando!”, “Os resistentes também amam!", frases comumente gritadas em alguns Slams quando poetas falam de amor, abrem esse texto lado a lado à Conceição Evaristo, que propõe o conceito de escrevivência como a apropriação da escrita por mulheres negras. Uma posse que subverte a noção de escrita como instrumento de conservação das hierarquias, principalmente, raciais, e reservado às classes dominantes. Do mesmo modo, o conceito de escrevivência registra o que, a partir da oralidade, já é transmitido e preservado por nós, pessoas negras, na escrita, na vivência, no corpo. A escrevivência é a escrita que nasce de uma experiência ou lembrança que é vivenciada através da condição de um corpo social e racialmente marcado. Usamos, aqui, esse conceito enquanto ferramenta metodológica de produção de conhecimento (SOARES; MACHADO, 2017) e de subversão de hegemonias raciais e de gênero.

Nossas escrevivências na roda do Slam Chamego, espaço em que, através da poesia, fala-se de amor e afeto em suas mais diversas manifestações, nos permitiu refletir e propor uma escrita sobre o impacto de pessoas negras falarem de amor e/ou afetividade, entendendo o contexto de extrema violência em que nossos corpos se constituem. Apontaremos, também, o Slam enquanto uma iniciativa que positiva a identidade negra, constrói espaços de resistência, cuidado e emancipação, além de reconstruir a afetividade da juventude negra.

\section{Afetividade, memória e corpo: a integralidade da violência contra o corpo negro na diáspora}

Para pensar afetividade entre negros(as) é indispensável ressaltarmos que o Brasil foi o último país ocidental a abolir a escravização no mundo, que possui a maior população negra fora de África e uma herança colonial extremamente presente e violenta operando socialmente (BORGES, 2017). A partir do racismo enquanto 
estrutura, sistema de aprendizagem e elemento alicerçador das diferentes formas de se relacionar social e institucionalmente, e simultaneamente aos processos de resistência, as pessoas negras têm sido violentadas, assassinadas física e simbolicamente, marginalizadas, excluídas e destituídas de sua humanidade cotidianamente. Num regime de insensibilidade, ou de uma sensibilidade seletivamente racista a nível mundial, em relação à dimensão do problema pouco é proposto e/ou efetivamente implementado nas vias de um enfrentamento antirracista enquanto política urgente e de responsabilidade estatal. Segundo Carlos Moore (2007), o racismo produz essa insensibilidade em quem o pratica, ativamente ou não, o que não evita que nós, pessoas negras, deixemos de sentir seus impactos.

Meninas negras começam a olhar para os seus corpos insatisfeitas e transformam aquilo que lhes é possível de modificar: as vestimentas, as maquiagens e os cabelos. Meninos negros preocupam-se em tornarem-se másculos e bons em alguma atividade: no futebol, na rima ou na sedução. William Pinar (2008) afirma que "o corpo do negro é visto pejorativamente em relação ao do branco; ressaltandose principalmente os atributos ligados à força física (ligados à capacidade para o trabalho manual) e a uma hiperssexualidade, quase descontrolada" (apud ZAMORA, 2012, p. 567). Esta autora em seguida ressalta que:

Desde cedo, na mídia e na escola, senão na própria família, a criança negra vê e sente a desvalorização de seu corpo e a fundamentação de padrões estéticos que desprezam o seu tipo, reservando a ideia de beleza para o tipo branco, quando não o nórdico. Tornar-se negro, portanto, é vencer inúmeros obstáculos, onde o referencial é sempre o mundo branco; é um desafio doloroso (ZAMORA, 2012, p. 568).

Contudo, por entre movimentos de emancipação, identidade negra, panafricanistas, afrocentrados eas pessoas que os compõem voluntária e involuntariamente a partir das resistências dos seus corpos em movimento e da autoafirmação numa sociedade racista, toda essa violência endereçada à população negra é percebida, lida e pensada, também teoricamente, enquanto demanda e agenda destes coletivos. Assim, é proposta uma organização que é antirracista, política e atua combatendo esses padrões de violência, ao passo em que resgata valores e evidencia as formas de cuidado oriundas da matriz africana, positiva a identidade negra e constrói espaços de resistência e emancipação. Estes coletivos e organizações estão presentes nos terreiros de religiões afro-brasileiras, nas escolas de capoeira e de samba, nas universidades, no Movimento Negro Unificado ${ }^{78}$, nos Slams, nos quilombos, no movimento hip-hop, entre outros movimentos e coletivos.

bell hooks ${ }^{79}$ (2006), no texto "Vivendo de Amor", se propõe a fazer esse trabalho de emancipação e explora o quanto nós, pessoas negras, somos intensamente marcadas pelo processo de escravização em nossas subjetividades, o que resultou na nossa impossibilidade aparente de exercer e demonstrar sentimentos e emoções. Porém, a partir dessa impossibilidade, sentimentos e emoções foram redirecionados a outras formas de praticá-los e senti-los. A escravização deixou-nos despreparadas para amar e sentir emoções positivas. Desse modo nos encorajou e demandou que nossas estratégias de sobrevivência fossem nossa finalidade existencial.

A masculinidade negra seria extremamente atravessada por essas questões e pela autodestrutividade, e reforçada no encontro com uma sociedade que exercita o controle e o poder sobre a vida e a morte dessa população. É pelo corpo negro, e muitas vezes masculino, que as técnicas de poder atuam no sentido do extermínio físico massivo, além do simbólico (BORGES, 2017). Pode ser estatisticamente comprovado que há um processo de continuidade e aprofundamento da desigualdade racial nos indicadores de violência letal no Brasil, visto que, em 2017, 75,5\% das vítimas de homicídios foram de pessoas negras, e em sua maioria homens (IPEA, 2019). Já as mulheres negras, ainda segundo bell hooks (2006), sentem as marcas do processo escravista nas suas emoções e sentimentos a partir de um desinvestimento de si e redirecionamento das suas capacidades de amar, sentir, cuidar e conhecer ao outro: seus filhos(as), os filhos(as) das senhoras da casa grande, os filhos(as) das patroas. Do mesmo

78 O MNU nasceu com o nome Movimento Unificado Contra a Discriminação Racial para desmascarar o racismo velado que havia e ainda há no Brasil, e foi também um marco na resistência contra a ditadura militar. Em 1978 ocorreu um ato público na escadaria do Teatro Municipal, em Sao Paulo, para denunciar manifestações nazes, zona Sul da cidade; além da segregacá̃o de atletas negros, jogadores de vôlei do Clube de Regatas Tietê, nazes, zona Sul da cidade; além da segregação de atletas negros, jogadores de vôlei do Clube de Regatas Tietê,
impedidos de entrar na piscina. Segundo seus fundadores, o MNU colocou a termo "NEGRO" no vocabulário impedidos de entrar na piscina. Segundo seus fundadores, o MNU colocou a termo "NEGRO" no vocabulário corrente. Em 2018, o MNU completou 40 anos de atuação antirracista na sociedade brasileira (GELEDÉS, 2018).
79 bell hooks é o pseudônimo de Gloria Jean Watkins. O apelido que ela escolheu para assinar suas obras é uma 79 bell hooks é o pseudônimo de Gloria Jean Watkins. O apelido que ela escolheu para assinar suas obras é uma hiçōes ortográficas (hooks, 2013). Disponível em: https://www.geledes.org.br/vivendo-de-amor/. Acesso em: 19 jul. 2019. 
modo, a letalidade e os índices de violência registram mais mulheres negras como vítimas em relação às mulheres não-negras (IPEA, 2019).

Abdias Nascimento (2009) reflete sobre um dos focos da relação entre os negros brasileiros e as possibilidades de ser e sobreviver ao processo colonial e de escravização, considerando fundamentalmente a violência endereçada contra a memória e a consciência da população negro-africana no país. Segundo ele, a escravização não seria possível se, entre outros fatores, os europeus não fizessem de tudo para massacrar a memória dos africanos recém-chegados no Brasil (NASCIMENTO, 2009). A África enquanto um continente em pleno desenvolvimento na época pré-colonial, com várias conquistas sociais e científicas partindo primeira e principalmente do Egito (DIOP, 1974), deveria ser apagada da memória dos negros-africanos. Somente assim seria possível sustentar um processo tão intenso de desumanização e violência, como a escravização. Desse modo, em todo o processo colonial, os quilombos tiveram um papel essencial e fundamental para os negros e para a sociedade brasileira, pois mantinham viva a imagem de África, libertavam física e psicologicamente os africanos, promoviam dignidade e poder sobre suas vidas.

A palavra "Negro", para Achille Mbembe (2014), se constitui como um produto resultante de um processo no qual pessoas de origem africana são transformadas em minerais vivos, e extraídas, como foi o caso do processo de escravização (MBEMBE, 2014, p. 78). Johnson (2005) vai nomear essa transformação das pessoas africanas como "homem-mineral", "homens-metal" e "homem-moeda" (apud MBEMBE, 2014, p. 78). Porém, esse termo não designa a uma realidade e sim a um conjunto de alucinações do ocidente, herança direta da sua etnologia e das filosofias da história dividindo sociedades em primitivas, regidas por uma mentalidade selvagem e civilizadas, governadas pela razão (MBEMBE, 2014, p. 81). Mbembe (2014), aponta que a palavra "Negro” não existia em África:

Este nome foi inventado para significar exclusão, embrutecimento e degradação, ou seja, um limite sempre conjurado e abominado. Humilhado e profundamente desonrado, o Negro é, na ordem da modernidade, o único de todos os humanos cuja carne foi transformada em coisa, e o espírito, em mercadoria - a cripta viva do capital (MBEMBE, 2014, p. 19).
O que existiu foram conceitos fantasmagóricos e ficcionados de raça para um projeto moderno de conhecimento, de governação. Nogueira (2014) afirma, ainda:

Vale a pena registrar que uma espécie de racismo antinegro é a desumanização radical que se transborda em zoomorfização sistemática. Os povos negros foram interpretados pelos europeus como criaturas sem alma, animalizados, tomados como coisas. O eurocentrismo colonial dividiu os seres humanos em raças e desqualificou todos os povos não europeus; mas isso incluiu algumas gradações. E, sem dúvida, os povos africanos foram designados pelo eurocentrismo como menos desenvolvidos. A zoomorfização sistemática desses povos foi um elemento decisivo para embasar a escravidão negra (apud RIBEIRO, 2017, p. 48).

Simultaneamente aos movimentos de transformação, ainda em curso, da palavra e da identidade negras enquanto signos sociais, podemos pensar na violência que é endereçada aos corpos negros na diáspora em toda sua integralidade, no caso brasileiro. Essa violência compreende a impossibilidade dos sujeitos sobreviverem numa sociedade que os ataca física, subjetiva e cognitivamente através do corpo, das suas potencialidades afetivas e da sua memória, respectivamente. Entretanto, compreendemos que esse ataque é cuidadosamente arquitetado social e institucionalmente, não como mera consequência de um processo escravagista tão longo, mas também como única e já conhecida possibilidade de dominação das mais importantes dimensões de uma pessoa. Mbembe (2014, p.19) relata que ao mesmo tempo em que o termo "Negro" é construído como objeto e animalidade, em uma reviravolta espetacular o Negro "tornou-se símbolo de um desejo consciente de vida, força pujante, flutuante e plástica, plenamente engajada no ato de criação e até de viver em vários tempos e várias histórias ao mesmo tempo". O autor ainda descreve o nascimento da identidade negra enquanto afirmação política de existência, a partir de um movimento de subversão nas obras de muitos poetas de origem africana (MBEMBE, 2014). O movimento dos poetas da negritude onde o substantivo "Negro" não remete mais à experiência do vazio a ser preenchido. A transformação do substantivo no conceito "Negro" torna-se o signo a partir do qual as pessoas de origem africana se anunciam, e se mostram para o mundo e se afirmam como mundo.

Os quilombos, na ocasião da escravização, foram a possibilidade de fuga e cuidado mútuo encontrada pelos africanos em diáspora. Outros espaços de cuidado são atualizados e a arte está muito atrelada a isso. Nossa proposta nessa escrita é 
apresentar as rodas de poesia conhecidas como Slam como um desses espaços, com destaque ao Slam Chamego, que é vivenciado pelo(as) autor(as) do presente texto.

Os resistentes também amam: a resistência da juventude preta no slam brasileiro

\author{
Já imaginou? \\ Nós dois \\ Super-heróis do gueto \\ Tipo dois Orixás \\ Eu Iansã e você Ogum \\ Nossas armaduras \\ Vermelho e azul \\ Nossas armas \\ Um Raio e uma espada \\ Nosso reino... \\ O morro inteiro \\ Nosso banquete \\ Pela manhã um bolinho de fubá \\ Meio-dia Vatapá \\ E a tardinha um amalá \\ Nossos templos em Yorubá \\ Nossas meninas \\ Omo birin obá \\ E nossas mães \\ Àyabás \\ Nossos griôs os preto véio \\ E em cada canto o nosso teto \\ Já imaginou? \\ Nós dois... Super-heróis do gueto \\ A favela descendo o morro \\ $O$ asfalto virando gueto \\ E finalmente tudo escurecendo \\ Nós dois \\ Super-heróis do gueto \\ Trazendo uma nova civilização \\ Aí sim, seria a redenção. \\ (BEVENUTO, 2018)
}

Beatriz Nascimento (1985) aponta à importância e às (re)significações da instituição "quilombo" desde o período pré-colonial até a atualidade. O quilombo, inicialmente, constituía-se como uma instituição de organização social e resistência, a partir do agrupamento de grupos étnicos distintos da Angola (kilombo), frente à penetração portuguesa. Quando do processo de escravização, tal instituição é importada para o Brasil, assumindo um caráter ideológico de fuga ao colonialismo, sendo organizada e constituída de diferentes formas que permitiram sua existência, e traduzindo-se em verdadeiro sinal de perigo à estabilidade do Império. A autora examina ainda da passagem do entendimento de quilombo enquanto instituição para um entendimento de princípio ideológico, ao afirmar que a partir do Brasil republicano, especificamente a década de 1970, muito marcado pela repressão política e social da ditadura militar vigente, e se valendo da retórica do quilombo, "os negros puderam inaugurar um movimento social baseado na verbalização ou discurso veiculado à necessidade de auto-afirmação e recuperação da identidade cultural” (NASCIMENTO, 1985. p. 123). A partir das estratégias culturais e/ou de mobilização social pautadas neste entendimento,

Quilombo passou a ser sinônimo de povo negro, sinônimo de comportamento do negro e esperança para uma melhor sociedade. Passou a ser sede interior e exterior de todas as formas de resistência cultural. Tudo, de atitude à associação, seria quilombo, desde que buscasse maior valorização da herança negra (NASCIMENTO, 1985, p. 124).

Sob o escopo de tais formas de resistência cultural, privilegiamos a participação de pessoas negras no movimento Slam, entendendo-o como um espaço de escuta e compartilhamento para poesias faladas. O Slam pode ocorrer em forma de competição ou de "verso livre", sendo este último o modo em que a pessoa participante recita alguma poesia, autoral ou não, sem competir e ser avaliada por uma banca de jurados(as). O poema da poeta Morghana Benevenuto (2018), que abre esta seção do texto, sintetiza em suas linhas o motivo de entendermos o Slam como uma estratégia de quilombo ideológico a partir do potencial subversivo da arte. Em suas rimas, essa jovem negra nos apresenta uma relação de afeto construída a partir dos elementos da matriz africana, presentes nos terreiros da diáspora brasileira, centralizando-os na construção da sua 
experiência emocional. A valorização da herança negra, exercida por poetas como ela, torna o Slam um campo de potencialidade de transformação subjetiva.

O Slam que chega ao Brasil em 2008 com a criação do Zap! Slam ${ }^{80}$ foi organizado pela atriz, poetisa, música e apresentadora do Programa "Manos e Minas" da Tv Cultura, Roberta Estrela D’Alva, na cidade de São Paulo. Idealizado após uma viagem da atriz aos Estados Unidos, onde teve contato com o movimento Slam, o Zap! Slam buscou constituir-se em um espaço de cultura e resistência, nos mesmos moldes do projeto original norte-americano (D’ALVA, 2019). De fato, isso tem se concretizado até hoje, pois vivenciamos uma explosão de iniciativas de Slam por todo o país, sendo várias delas marcadas por ocorrerem em periferias, voltadas para a juventude que ali reside. Além disso, a grande maioria dos Slams reivindica ser um espaço de resistência e produção cultural e artística a partir das vivências dos indivíduos que ali estão.

Alguns Slams têm temas específicos, como é o caso do Slam Chamego ${ }^{81}$, de Porto Alegre, primeiro Slam temático do estado do Rio Grande do Sul, onde só podem ser declamadas poesias que falem de amor e desamor ou das mais diversas manifestações de afeto; e o Slam do $\mathrm{Gozo}^{82}$, também na mesma cidade, tendo as poesias eróticas como critério de participação.

$\mathrm{O}(\mathrm{A})$ poeta que deseja participar como competidor(a) do Slam deve seguir algumas regras. Geralmente a primeira regra explicadas pelos(as) slammasters ${ }^{83}$ no começo de cada evento refere-se à quantidade e ao tempo de duração das poesias: o(a) slammer (quem recita) deve possuir pelo menos três poesias autorais, podendo conter citações a outros autores(as), desde que indicadas de alguma forma. A duração deve ser de, no máximo, três minutos cada, sendo descontados 0,05 pontos da nota final quando passados dez segundos do tempo limite. Quando o tempo limite é atingido, há um acordo mútuo de que todas as pessoas ouvintes ergam os braços como forma de interagir com quem recita, avisando-o(a) de que o tempo acabou. Uma segunda regra diz respeito à proibição do uso de acompanhamento musical e de adereços cênicos, o que significa que quem está declamando não pode se valer de nenhum objeto para encenar algo que esteja no conteúdo de sua poesia. Isso incentiva o(a) slammer a construir uma performance/interpretação da

\section{$80 \quad$ Zona Autônoma da Palavra.}

81 Informações disponíveis na página do Facebook do Slam Chamego. Disponível em: https://www.facebook.com/SlamChamego/. Acesso em: 15 jul. 2019.

82 Informações disponíveis na página do Facebook do Slam do Gozo. Disponível em: https://www.face$83 \quad$ Nome atribuído às pessoas que organizam os Slams. poesia se valendo do seu próprio corpo, usando movimentos, gingas, expressões faciais e alterações na voz e na velocidade para construir a história narrada, a fim de envolver o público ouvinte. O júri do Slam, cuja função principal é dar notas de zero à dez ao final das poesias dos(as) competidores(as), é composto por cinco pessoas da plateia - ou seja, quem deseja competir não pode participar como jurado(a) - escolhidas aleatoriamente. Porém, há uma preferência por pessoas que não tenham nenhum envolvimento com qualquer um dos(as) competidores(as), ou que estejam participando do Slam pela primeira vez. É muito comum que a escolha seja feita em paridade de gênero, e em alguns Slams se busca também uma preferência por pessoas negras no júri, o que demonstra uma variabilidade na execução da referida regra. Por fim, uma das regras mais importantes é a que diz que "o silêncio é uma prece", frase constantemente repetida nas rodas de Slam sul-rio-grandenses. Ela indica a importância do silêncio frente ao ou à poeta que está declamando, como uma forma de respeito e acolhida àquela verdade que está sendo trazida e compartilhada na roda. Porém, isso não significa que quem ouve não pode interagir com quem declama. No Slam, é de praxe que quando alguma frase impactante e/ou envolvente é dita pelos(as) slammers, o público reaja com exclamações como "WOW", "NOSSA", “AIIIII!", “TRRRRRRÁ!!”, “TCHUN-TCHÁ," etc. Dito isso, extremamente importante ressaltarmos este caráter interativo entre público-slammer, pois é um dos elementos mais presentes e constitutivos da roda e das relações que ali se constroem.

No Brasil, o Slam carrega algumas características específicas. A primeira que nós gostaríamos de ressaltar é referente à localidade onde ocorre: a rua. Em sua grande maioria, os Slams brasileiros ocorrem em praças, viadutos, centros culturais de bairros periféricos e outros espaços públicos. Essa característica torna-se importante para entendermos quais os públicos que majoritariamente frequentam tais eventos: pessoas jovens de classe popular, cuja entrada entrada e participação facilitadas pelo caráter gratuito de estadia no espaço, estudantes universitários, no caso dos Slams centrais, e jovens de classe média que já tendem a participar de outros eventos de rua na cidade. Um segundo elemento interessante de ser observado da dinâmica organizativa dos Slams é o fato de que eles ocorrem, quase sempre, em roda. Quem está declamando fica no meio e todos os ouvintes se aconchegam em sua volta, preferencialmente sentados. Acreditamos que a influência do rap brasileiro e do movimento de batalhas de rima também são importantes para entender o caráter não elitizado e de maior liberdade na prática da poesia do Slam. 
A ênfase na sonoridade, no sentido das palavras e na interpretação do(a) poeta, muito presentes no rap e nas batalhas de rima, são elementos que compõem e tornam o Slam tão único. Como é o público quem decide o(a) vencedor(a) das competições, muitas vezes os(as) intérpretes buscam adicionar uma dramaticidade na interpretação de seus poemas, utilizando-se de movimentos corporais, entonações diferentes de voz, bem como alterações na velocidade da fala para cativar os(as) ouvintes, tudo no intuito de provocar a plateia e envolvê-la na narrativa apresentada.

\section{O silêncio é uma prece: a oralidade do Slam chamego e a} reconstrução do afeto preto

Muitas mulheres negras sentem que em suas vidas existe pouco ou nenhum amor. Essa é uma de nossas verdades privadas que raramente é discutida em público. Essa realidade é tão dolorosa que as mulheres negras raramente falam abertamente sobre isso.

hooks (2006)

Antes de falarmos de amor é importante falarmos de silêncio. Não o silêncio como prece da roda de Slam que simboliza respeito e acolhimento, mas o processo de silenciamento que muitas vezes foi elemento constitutivo das afetividades negras. bell hooks (2013) chama a atenção para o silêncio enquanto ato de cumplicidade de uma determinada ação que ajuda a perpetuar uma certa ideia, no caso ela se referia ao engajamento na libertação negra revolucionária e na luta feminista sem a teoria, porque a intelectualidade era remetida a uma ideia de ausência de prática. A autora entendia as palavras enunciadas por nós, pessoas negras, como uma ação e que discutir questões de gênero e negritude sem censura era uma prática subversiva considerando "as crises que enfrentamos como afro-americanos, com nossa necessidade premente de reavivar e manter acesa a chama da luta pela libertação negra" (hooks, 2013, p. 93). A autora relata sobre como se aproximou da teoria em um momento em que ela estava machucada, desesperada com uma dor tão intensa em que não via possibilidade de continuar vivendo. Buscou no processo de teorização uma alternativa para explicar tudo que ela observava ao redor e afirma que, para ela, a teoria foi um local de cura. Porém, explica que a teoria em si não cura a não ser que ela seja endereçada para esse fim.
A poesia recitada no Slam tem determinado endereço explicitado nas palavras do(a) poeta. Como podemos exemplificar no poema abaixo:

Ninguém fala sobre a construção da mulher negra

Só pegam a história no fim quando a desconstrução já tá feita

Não falam da fase que ela é a nêga feia que alisa o cabelo pra ser aceita

Não falam dessa fase porque é muito mais fácil ignorar algo quando não faz parte

da tua realidade.

Não falam da sentença que a gente carrega desde criança

E que na adolescência a gente vai ser taxada de puta

Por dar moral pra muito otário na rua.

Até perceber a verdade nua e crua que...

Quanto mais cor, mais solidão.

Que até serve quando é preta, mas é só quando a branca não tá à disposição.

Ah! Tá achando que é exagero?!

Então me diz por que que a maioria é mulher negra que eu vejo vivendo em cativeiro?

É que ninguém nos ensinou a nos amar

E por isso a gente acaba aceitando o resto de atenção que esses merda dá.

Quer saber por que tantas mulheres negras vivem em relacionamento

abusivo?!

É porque por mais que seja pouco esses caras foram os únicos que em algum

momento expressaram algum tipo de carinho.

$E$ eu só depois de tanto ver a minha mãe sofrer

Cansei de viver de farelo e hoje não tento mais justificar tanta falta de afeto.

Hoje me dá gosto de vê correndo atrás e poder dizer não.

Eu não sou mais a "morena" que você saia por segunda opção.

Então não toca! Porque eu não sou objeto a demonstração.

Também não sou prêmio pra tua competição e muito menos depósito pra tua ejaculação.

Eu não vou deixar de ser quem eu sou por medo da solidão. Porque se esse for o preço que eu devo pagar por ser minha

Por ser a preta da minha vida!

Que se dane!

Eu faço questão de ficar sozinha!

(TIATÃ, 2019) 
A poeta em questão fala sobre a construção da mulher negra e de como se deu seu entendimento em relação ao próprio corpo, visto como objeto sexualizado e desprovido de afeto, e a retomada da autoestima, do cuidado e do amor interior. Um relato poético da vida da poeta e que ecoa principalmente na vida de mulheres negras. Para Audre Lorde (1984), poeta, negra e lésbica, o silêncio não a protegia das opressões que sofria. Porém, as palavras a aproximavam de outras mulheres que, juntas, lutavam contra a tirania do silêncio. O silêncio que "desvia o olhar de seus próprios medos - medo do desprezo, da censura, do julgamento, ou do reconhecimento, do desafio, do aniquilamento" é transformado em linguagem e ação (LORDE, 1984, p. 23). Escrever, para a autora, é necessário para examinar não apenas a verdade do que falamos como a verdade da linguagem em que o dizemos, isto é, a responsabilidade sobre aquilo que se fala, sobre a sua escrita, reconhecendo a linguagem como papel vital para a transformação do silêncio. As palavras também servem para compartilhar e difundir ideias significativas a um determinado grupo. A oralidade para nós, pessoas negras, nos é muito importante e significativa.

Eudaldo Santos Filho e Janaína Alves (2017) refletem sobre a oralidade para povos africanos e afro-brasileiros e como a tradição oral se configura não apenas como instrumento de comunicação, mas como transmissor de saberes, valores e histórias de vida. De acordo com os autores, os povos africanos trazidos para o Brasil instalaram a tradição oral como forma de preservar e manter viva a memória dos antepassados. Ela é, com isso, "uma construção metodológica de difusão e construção de conhecimento de alguns povos" (SANTOS FILHO; ALVES, 2017, p. 52). A fala para as sociedades africanas é considerada sagrada estando, assim, diretamente ligada ao Ser divino da criação. Além do atributo espiritual, a fala também é uma forma de respeito aos ancestrais e aos anciãos, pois eles são fontes históricas, base para a constituição da sociedade africana, portanto, a palavra dos mais velhos era respeitada e incontestada. O que é dito pelo mais velho, sendo algo sagrado, é também de sua responsabilidade em relação à transmissão desse conhecimento aos mais novos que, por sua vez, devem confiar nos ensinamentos dos mais velhos.

$\mathrm{O}$ ato de falar requer esforços que vão além da eficiência do aparelho fonológico, a fala está imbricada no valor que a palavra tem e o que ela revela, carregando consigo a intencionalidade, o caráter do que é dito e a responsabilidade de quem está falando. [...] Isso tornou-se tradição na África, a comunicação oral é característica peculiar e preponderante de seus descendentes, que priorizam tal habilidade na interação das relações (SANTOS FILHO; ALVES, 2017, p. 56).

Podemos pensar sobre certos elementos da tradição africana que, atravessando gerações até chegar ao Brasil, expressam-se de forma constitutiva do Slam no Brasil, como a própria oralidade, a roda e a rua.

Tradição, segundo os autores, é entendida como "toda a forma de se comportar e proceder de um grupo social, que se fixa em seus membros e permanece na dimensão espaço-tempo" (SANTOS FILHO; ALVES, 2017, p. 56). $\mathrm{Ou}$ seja, aquilo que se estabelece e tem continuidade ao longo do espaço-tempo. Se analisarmos os movimentos de cultura de origem africana, perceberemos alguns elementos que se mantém vivos da tradição. No movimento hip hop, a transmissão de conhecimento através da oralidade se institui a partir das letras de rap, na mensagem que o $\mathrm{MC}^{84}$ transmite em seus shows, no Slam através do poema e da performance, nas letras do samba, entre outras tradições orais. "Tudo o que foi vivido fica arquivado nas mentes dos africanos e a melhor forma de transmissão é a oral, que carrega consigo as emoções, o gestual, as expressões corporais, sendo estes elementos indispensáveis no ato de falar" (SANTOS FILHO; ALVES, 2017, p. 58). Portanto, ao falar, além do aparelho fonológico, todo o corpo se expressa no ato, transmitindo sensações que só são capazes de ser percebidas por quem está prestando atenção e está conectado. O Slam ilustra essa afirmação no momento em que o(a) slammer fala alguma frase que provoca as exclamações já citadas do público: "WOW", "NOSSA", "AIIIII!", “CREDO" - ocorre este último quando um(a) jurado(a) destina uma nota considerada baixa, pelo público, ao ou à poeta.

É a partir da oralidade das poesias faladas do Slam e da expressão das emoções contidas nelas que o amor se apresenta e se reinventa. bell hooks (2006) atenta para o potencial curativo do amor na reconstrução subjetiva dos sujeitos negros que conseguem exercê-lo de forma plena. Numa sociedade como a nossa, permeada pela negação da validez do amor de pessoas negras - seja por si ou por outros(as) -, encontrar estratégias inovadoras para se permitir sentir e expressar o amor faz parte da estratégia de sobrevivência. Enquanto slammers, os poetas

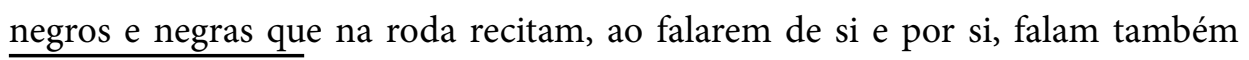
84 MC é usada para designar o Mestre de Cerimônia, geralmente quem escreve e canta o rap. 
de um grupo e por um grupo. Reconstroem narrativas sobre seus corpos e suas existências, ampliando as possibilidades de entendimento e experienciação do que é ser um sujeito negro no mundo, através do uso ativo da palavra, e exercem o afeto não só ao recitarem na competição, mas também ao torcerem pelos(as) outros(as) competidores(as) e se sentirem representados por eles(as). Para Lissandra Soares e Paula Machado (2017, p.207), as "escrevivências" carregam uma dimensão ética ao propiciarem que o(a) autor(a), "assuma o lugar de enunciação de um eu coletivo, de alguém que evoca, por meio de suas próprias narrativas e voz, a história de um 'nós' compartilhado". Pensar em escrevivência e slam é pensar em uma subversão na produção de conhecimento, como as autoras propõem, por introduzir "uma fissura de caráter eminentemente artístico na escrita científica" (SOARES; MACHADO, 2017, p.207), como é feito no trecho abaixo:

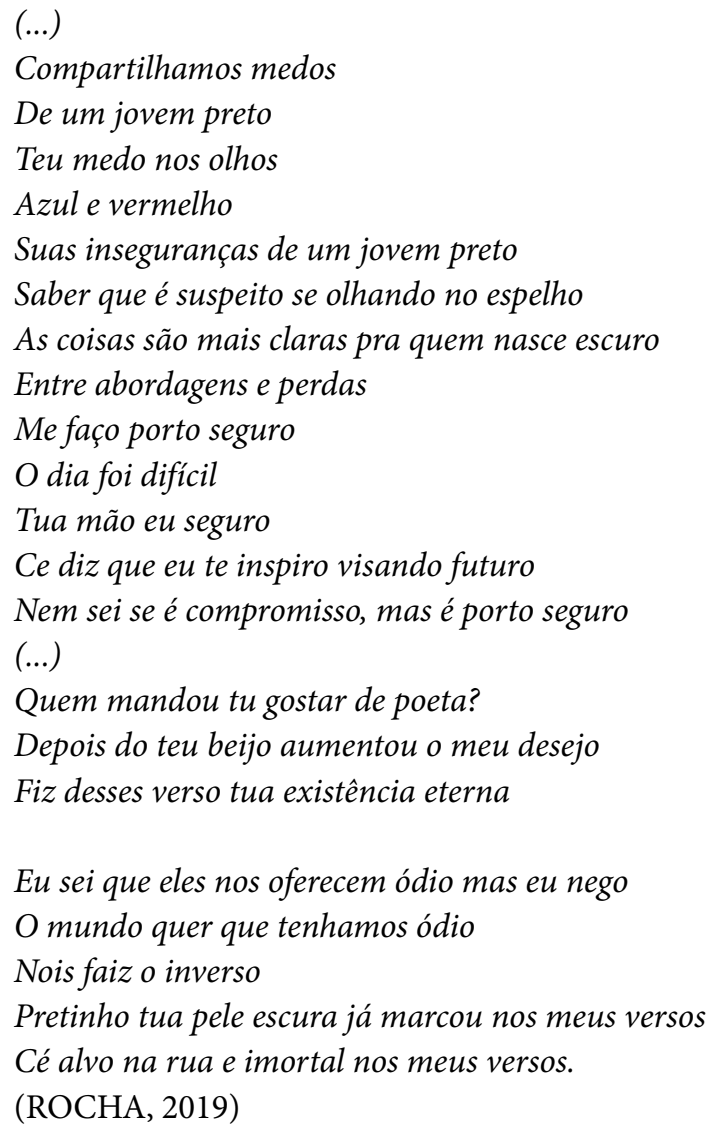

Nessa passagem, a partir de uma experiência pessoal poetizada, a poeta Cristal Rocha (2019) apresenta elementos compartilhados por toda a juventude negra que enfrenta os mecanismos racistas de poder e dominação diariamente, mas vai além disso, produzindo uma inflexão nessa rota através do amor enquanto eixo de transformação. Poetizar, dessa forma, impacta não só sua existência, ao reforçar sua experiência como válida e reafirmar a emoção vivida, mas também amplia o campo de inteligibilidade do que é ser uma pessoa negra para todos(as) aqueles(as) que a escutam, sejam pessoas negras ou brancas. Dessa forma, os processos de subjetivação de sujeitos negros se atualizam através de um campo de possibilidades de corpos, vivências e afetos não-hegemônicos. Noguera (2012) cita um provérbio Gikuyu ${ }^{85}$ que diz “a avareza não alimenta”. Quer dizer, na perspectiva Ubuntu" ${ }^{86}$, que a realização de uma pessoa passa pelas outras pessoas e a construção individual passa pela capacidade de partilhar com as outras. Poetas do Slam podem não ter ideia do que significa a palavra Ubuntu, mas ao citar outros poetas na roda, ao torcer pelo sucesso do outro na competição, ao insistirem pela participação como competidor(a), e não apenas no verso livre, de poetas novos nos eventos, eles estão exercendo o "ubuntu como modo de existir e uma re-existência, uma forma afroperspectivista de configurar a vida humana coletivamente, trocando experiências, solidificando laços de apoio mútuo e aprendendo sempre com os outros" (NOGUERA, 2012, p. 149).

\section{Pretas e pretos estão se amando: de que modo pensar o afeto como ato revolucionário?}

Acreditamos que "o silêncio é uma prece" da roda de Slam simboliza o espaço de escuta e acolhimento, onde o(a) slammer coloca a sua palavra em ação. Pessoas negras tencionam, através de sua poesia, o processo de silenciamento e desumanização ao qual foram acometidas. O processo de apagamento de nossa identidade devido ao racismo que estrutura nossa sociedade não nos impediu de resistir, apesar das marcas que atravessam nossos corpos. A oralidade, estratégia de resistência, de difusão e de partilha de conhecimento, carrega consigo a força e a responsabilidade de quem tem na poesia uma ferramenta para transmitir $85 \quad$ Grupo étnico localizado no Quênia.

86 Ubuntu é uma palavra compartilhada por quatro grupos étnicos africanos (ndebele, swati, xhosa e zulu), cujo significado propõe uma "maneira de viver, uma possibilidade de existir junto com outras pessoas de forma não egoísta, uma existência comunitária antirracista e policêntrica" (NOGUERA, 2012, p. 147). 
mensagens que falam de nossos processos afetivos, dolorosos ou não. A ideia do Slam como uma forma atual de quilombo é o reconhecimento e a possibilidade de transmissão de nossa herança cultural, que atravessa séculos e ainda resiste e valoriza nossa ancestralidade.

O Slam Chamego é uma roda de poesia falada que tem como proposta falar de afeto. Afeto que por todas as razões que citamos no decorrer desse artigo nos foi negado o exercício. Mas que, quando compartilhado na roda reconstrói não só nossas representações internas - e, assim, nossa subjetividade -, mas também nossa existência cognitiva, retomando essa herança negra, essa memória, e nosso corpo físico, a partir do ato de pensarmos sobre nós e assim nos cuidarmos, e compartilharmos este cuidado com o coletivo nas trocas de afetos. "Abaixa a guarda e peito!", mais que uma chamada para a performance do(a) slammer, pensamos ser um pedido para nós, pessoas negras, investirmos mais em nossos afetos, investirmos mais em nossa herança, em nossos corpos, e assim, em nossa reconstrução coletiva.

\section{Referências}

ALVES, Jaênes Miranda. Competitividade e tendência da produção de manga para exportação do nordeste do Brasil. 2002. 147 f. + 1 CD-ROM. Tese (Doutorado em Economia Aplicada) - Escola Superior de Agricultura "Luiz de Queiroz", Universidade de São Paulo, Piracicaba, 2002.

BENEVENUTO, Morghana. Já Imaginou? Vencedora Slam Chamego 1 ${ }^{\text {a }}$ Edição, 2018. Disponível em: $<$ https://www.facebook.com/SlamChamego/videos/1041459669346024/>. Acesso em: 18 jul. 2019.

BORGES, Juliana. Necropolítica na metrópole: extermínio de corpos, especulação de territórios. Geledés, 2017. Disponível em: <https://www.geledes.org.br/necropolitica-na-metropoleexterminio-de-corpos-especulacao-de-territorios/>. Acesso em: 10 jul. 2019.

D’ALVA, Roberta Estrela. Programa Nação - Slam de Poesia. TVE-RS, Porto Alegre, 28 Jul. 2017. Disponível em: $<$ https://youtu.be/lNO54PXZMYM $>$. Acesso em: 18 jul. 2019.

DIOP, Cheikh Anta. The African origin of civilization: myth or reality? Tradução Mercer Cook. Westport: Lawrence Hill, 1974.

EVARISTO, Conceição. A "escrevivência” na literatura feminina de Conceição Evaristo. [Entrevista cedida a] Bruno Barros. 14 min. 28s. Rio de Janeiro: TV PUC-Rio, 16 Mai. 2017. Disponível em: https://www.youtube.com/watch?v=z8C5ONvDoU8. Acesso em: 10 jul. 2019.

GELEDÉS. \#Geledes30anos: Ações do Movimento Negro Unificado e Geledés contra o racismo. Geledés, 2018. Disponível em: <https://www.geledes.org.br/acoes-do-movimento-negrounificado-e-geledes-contra-o-racismo/>. Acesso em: 14 ago. 2019.

hooks, bell. Ensinando a transgredir: a educação como prática de liberdade. São Paulo: WMF Martins Fontes, 2013. hooks, bell. Vivendo de amor. Tradução de Maísa Mendonça. Geledés [Online], 2010. Disponível em: <https://www.geledes.org.br/vivendo-de-amor >. Acesso em: 19 jul. 2019.

IPEA - INSTITUTO DE PESQUISA ECONÔMICA APLICADA. Atlas da Violência 2019. Brasília: IPEA, 2019. Disponível em: <http://www.ipea.gov.br/portal/index.php?option=com content\&view=article\&id=34784\&Itemid=432>. Acesso em: 15 ago. 2019.

LORDE, Audre. "Irmã Extranjeira” (Sister Outsider). Ensaios e Conferências, 1984. Disponível em: <https://www.mpba.mp.br/sites/default/files/biblioteca/direitos-humanos/direitos-dapopulacao-lgbt/obras digitalizadas/audre lorde - textos escolhidos portu.pdf $>$. Acesso em 6 mai 2019

MBEMBE, Achille. Crítica da razão negra. Antígona: Lisboa, 2014.

NASCIMENTO, Abdias. Quilombismo: um conceito emergente do processo histórico-cultural da população afro-brasileira. In: NASCIMENTO, Elisa Larkin. (Org.). Afrocentricidade: uma abordagem epistemológica inovadora. São Paulo: Selo Negro, 2009. (Sankofa: matrizes africanas da cultura brasileira, 4). p. 197-218

NASCIMENTO, Beatriz. O conceito de quilombo e a resistência cultural negra. In: RATTS, A. (Org.). Eu sou atlântica: sobre a trajetória de vida de Beatriz Nascimento. São Paulo: Instituto Kwanza, 1985. p. 117-125.

NOGUERA, Renato. Ubuntu como modo de existir: elementos gerais para uma ética afroperspectiva. Revista da ABPN, Uberlândia, v. 3, n. 6, p. 147-150, 2012.

RIBEIRO, Katiúscia. Kemet, Escolas e Arcádeas: A importância da Filosofia Africana no combate ao racismo epistêmico e a lei 10639/03. 2017. Dissertação (Mestrado em Filosofia e Ensino) - Centro Federal de Educação Tecnológica Celso Suckow da Fonseca, Rio de Janeiro, 2017. Disponível em: <https://filosofia-africana.weebly.com/uploads/1/3/2/1/13213792/kati\%C3\%BAscia ribeiro dissertac\%CC\%A7a\%CC\%83o final.pdf $>$. Acesso em: 18 ago. 2019.

ROCHA, Cristal. Imortal nos meus versos. 2019. Inédito.

SANTOS FILHO, Eudaldo Francisco dos.; ALVES, Janaína Bastos. A tradição oral para povos africanos e afrobrasileiros: Relevância da palavra. Revista ABPN Ed. Especial - Caderno Temático: Saberes Tradicionais, Uberlândia, v.9, p. 50-76, 2017.

SOARES, Lissandra Vieira; MACHADO, Paula Sandrine. "Escrevivências" como ferramenta metodológica na produção de conhecimento em Psicologia Social. Revista psicologia política, São Paulo, v. 17, n. 39, p. 203-219, 2017. Disponível em: <http://pepsic.bvsalud.org/scielo. php?script $=$ sci arttext\&pid=S1519-549X2017000200002\&lng $=$ pt\&nrm=iso $>$. Acesso em: 6 maio 2019.

TIATÃ [Vanessa Mesquita]. Desabafo poético com Tiatã. Justiça Poética, 28 jan. 2019. Disponível em: <https://www.youtube.com/watch?v=AoOw 6fGQF8\&amp;feature=youtu.be. $>$ Acesso em: 17 jul. 2019.

ZAMORA, Maria Helena Rodrigues Navas. Desigualdade Racial, racismo e seus efeitos. Fractal, Revista de Psicologia, Niterói, v. 24, n. 3, p. 563-578, 2012. 
CONTRIBUIÇÕES À REFLEXÃO AFROCÊNTRICA: APRENDIZAGENS MATRICENTRAIS EM PROCESSOS DE LONGA DURAÇÃO

Jefferson Olivatto da Silva Márcia Denise de Lima Dias Thais Rodrigues dos Santos

Nossa proposta tem por objetivo dialogar com a perspectiva afrocêntrica para compreendermos os processos matricentrais de cuidado à aflição comunitária que foram difundidos a partir da África. De um lado, temos as pesquisas de Frantz Fanon $(1968 ; 2008)$ e Wade Nobles $(2008 ; 2013)$ sobre os efeitos psicossociais do racismo na população negra; de outro, procuraremos enfatizar em que medida Cheick Anta Diop (2014) e Ifi Amadiume (1997) proporcionam reflexões afrocêntricas sobre a perpetuação do ensino matricental a partir da gênese da humanidade. Para tanto, precisamos considerar que há processos históricos de longa duração como argumentados por Elikia M'Bokolo (2009) sobre as dinâmicas em África, muito antes da colonização. Assim, levantamos nossa tese de que a diáspora africana também trouxe com seus povos uma educação silenciosa, que pode ser percebida na afirmação desses ensinamentos de cuidado e acolhimento à alteridade humana em religiões de matriz africana e em irmandades de benzedeiras. Para tanto, elencamos como exemplo um centro de Umbanda e uma irmandade de benzedeiras, na região do Centro-Oeste do Paraná.

Inicialmente, podemos mencionar que os efeitos psicossociais do racismo ultrapassam a violência física. Como Wade Nobles (2008) mencionou, a violência racial precisa ser vista enquanto violência para além da violência, já que busca eliminar saberes, práticas culturais, concepções afrocêntricas de humanidade e self, além de perpetuar esse tipo de interação na sociedade capitalista. Ora, se esse tipo de violência é estruturante e encontra-se no cotidiano das instituições sociais, então se explica o motivo pelo qual se torna imperceptível, homogêneo e em um contínuo de categorias emocionais e cognitivas excludentes. Como asseverou Fanon (1968, p. 29), a imediaticidade que podemos observar do contexto colonial foi a criação de mundos cindidos, "antes de mais nada o fato de pertencer ou não a tal espécie, a tal raça". Nesses termos, podemos acompanhar o sentido sublime e terrível sobre os efeitos posteriores à colonização que ecoaram pela voz do poeta cabo-verdiano, Ovídio Martins (apud MEDINA, 1987, p. 464): "Somos os flagelados do vento-leste! Os homens esqueceram-se de nos chamar irmãos. E as vozes solitárias que temos sempre escutado são apenas as vozes do mar que nos salgou o sangue [...]”.

Vale ressaltar que Elikia M’Bokolo (2009) aponta as dinâmicas sociais plurais às quais as diferentes populações africanas estabeleceram em tipos e direções distintas. Nesse sentido, para se pensar a historiografia africana como narrativa e problema, ou seja, além de narrar os acontecimentos, locais e atores e como fazer isso, direciona-se a visão sobre essa população. A história-problema aponta um caminho para, além dos debates entre narrativas de especialistas, o trabalho da memória coletiva dos povos africanos, por mais longe que consiga alcançar. Por isso, o primeiro aspecto a levarmos em consideração é o das populações africanas em sua diversidade, mas que são uníssonas a seus ancestrais, e que precisam trazer à tona o reconhecimento de suas produções, suas conquistas, o como aprenderam a cuidar enquanto comunidades ancestrais. O segundo aspecto é que a colonização foi desastrosa, desestruturante e cruel contra as populações africanas (bem como das outras colônias em outros continentes), mas não absoluta. Ora, o desprezo às produções e modo de ser, sentir e agir africano instaurou o etnocentrismo colonial, que ignorou a capacidade criadora e criativa de acolher e estabelecer vínculos responsáveis pela gênese da humanidade.

Nesses termos, devemos ter em mente que esse processo exploratório do humano surge posteriormente na história da humanidade e não em sua gênese. Vale lembrar que Cheick Anta Diop (2014) propôs outra concepção da origem humana em termos civilizatórios, a partir de dados arqueológicos, quer como as primeiras ossadas hominoides e hominídeas, atribuídas até anteriormente à Lucy, Australopithecus afarensis, entre aprox. 3,9 e 3 milhões de anos atrás; quer como o Ardipithecus kadabba, entre aprox. 5,2 e 5,8 milhões de anos atrás; e o Orrorin tugenensis, entre aprox. 6 e 5,8 milhões de anos atrás (AVPH, 2019). Outrossim, como esplendor civilizatório, Diop (2014) aponta o Egito para o surgimento e a expansão tecnológica (arquitetura, urbanização, política, registros, etc.) para o restante do globo.

Assim, entre esses dois momentos sócio-históricos, Diop (2014) assevera que a humanidade não surgiu da disputa ou da violência, mas, teria surgido pelo cuidado da prole e do bando em um território de fartura, em que o outro, diferente, era acolhido e se tornava membro. Essa hipótese toma em si o princípio 
matricentral de cuidado e intimidade que as nossas primeiras mães ancestrais teriam exercido e ensinado suas famílias e filhos a se organizarem. Mesmo o homem, nesse caso, não era excluído, mas defensor desta organização para o bemestar da comunidade. Essa hipótese corrobora o entendimento de vida organizada em um ambiente acolhedor e de fartura como era a região africana entre Chade até Etiópia, caracterizando o que Diop (2014) chamou de Berço Meridional. Além disso, o desenvolvimento dessa relação intersubjetiva de intimidade e integração comunitária possibilitaria a reprodução e a mobilidade de grupos, tanto em direção para o Oriente Médio quanto para o restante do continente africano.

Por outro lado, à medida que temos como princípio epistemológico o acolhimento, refletindo um ambiente acolhedor e de fartura, podemos acompanhar o caminho da humanidade, igualmente, para regiões mais inóspitas. A escassez de alimento, proteção ou água teria levado os agrupamentos a disputas entre si como recurso de sobrevivência. Com a manutenção da disputa, teriam ascendido sistemas de organização que valorizavam os rituais de virilidade e de força, culminando no nascimento de organizações patricentrais, denominadas por Diop (2014) como Berço Nórdico.

Com efeito, somos chamados para refletir com Amadiume (1997) a respeito de seu argumento de sistemas matricentrais e patricentrais concorrentes e disponíveis aos membros das comunidades. As sociedades teriam assim, em tese, disponíveis os dois sistemas operantes e decorrentes de fluxos migratórios, isto é, o desenvolvimento das relações sócio-históricas teve à sua disposição combinações e variantes dessas centralidades intersubjetivas. Inclusive, podemos considerar que enquanto uma se acentuava no cenário das comunidades, à outra era reservada uma posição de menor destaque nas práticas culturais e na identidade coletiva. Conquanto, mesmo em territórios do Berço Nórdico, o entendimento da importância da mulher e mãe se manteve crucial para a organização comunitária; haja vista as estatuetas de Vênus que datam desde 30.000 anos atrás.

Nos dois últimos milênios temos presenciado a amplitude de relações intersubjetivas patricentrais, acentuando-se em conflitos e demonstração de símbolos de virilidade como disputa, força e brutalidade. Como Joseph Campbell (1992) apresentou em “As Máscaras de Deus - Mitologia Primitiva”, as mitologias acompanharam essas ênfases, o que teria convergido na ideia de deuses masculinos possuírem adolescentes, e não jovens, que deram à luz semideuses. Diante dessas ações de violência contra as mulheres, não devemos nos perder em nosso raciocínio afrocêntrico, posto que as mulheres continuaram a parir, cuidar da prole e ensinar às que estavam mais próximas, as meninas, a aprendizagem e a importância do cuidado, do acolhimento e da intimidade para o bem-estar comunitário. Se tais relações intersubjetivas estavam dispostas tangencialmente aos rituais de virilidade e pseudocriação, nas palavras de Obioma Nnaemeka (2003), eram perpetuados pela prole de forma silenciosa e, em alguns casos, ocultas na forma de segredos. Assim foi que, diante de ondas migratórias pelo continente africano, e diante dos dois sistemas disponíveis, as comunidades encontraram formas de lidar com determinadas tensões identitárias.

A título de exemplo, à região central africana entre Angola e Moçambique, a antropóloga Richards Audrey (1956) chamou de cinturão matriarcal. Nessa região encontramos ritos parecidos com os do Chisungu, dos Babemba (DA SILVA, 2016), quando ocorre a iniciação secreta da menina. Em um processo migratório interno tardio, no século XVII, grupos da região central da República Democrática do Congo teriam migrado para a Zâmbia e estabelecido novos postos tributários. Esses grupos dominavam a região e se casavam com filhas dos chefes locais. Com efeito, teria sido a causa pela qual o culto aos antepassados locais (inquices) de domínio feminino fosse deslocado, para que o culto aos chefes masculinos e estrangeiros, mipashi, ocupassem a posição central do cotidiano permanecendo sob o domínio masculino, bakabilo (DA SILVA, 2016). No entanto, além da importância do Chisungu, o culto dos inquices foi perpetuado de forma silenciosa enquanto ensinamento matricentral - mesmo que desprezado. Além disso, essa região foi palco de centenas de milhares de pessoas vendidas legalmente para fazendeiros e comerciantes brasileiros até 1888 . Por sua vez, seus descendentes trouxeram consigo na experiência comunitária e de longa duração os dois sistemas civilizatórios africanos, matricentral e patricentral.

Com Fanon (2008, p. 134), afirmamos uma postura afrocêntrica em termos psicossociais, visto que o autor relembra que "nem Freud, nem Adler, nem mesmo o cósmico Jung em suas pesquisas pensaram nos negros", e ainda mais ao postular que "o complexo de Édipo longe está de surgir entre os negros". Em seu trabalho posterior, "Condenados da Terra”, Fanon (1968) nos lembra que 
a colonização foi patogênica em seu sentido de produção de violência geradora de sofrimentos físicos e mentais para as sociedades locais e, igualmente, para os agentes coloniais. Vale lembrar que a ocupação do norte da África pela França teve início em 1830, até o início da Frente de Libertação Nacional (FLN), em 1954. Esse período colonial estruturou um cotidiano exploratório e de silenciamento das populações locais como em outras colônias.

Ao atender os argelinos da Frente de Libertação Nacional e os soldados que os torturaram e executaram, Fanon (1968) pôde observar o quanto essa violência produziu perturbações mentais em ambos. Por isso, não podemos entender que essa violência tenha dois lados ao se referir ao torturador e o torturado; mas que, o outro lado foi causado pela exploração colonial, gerando riquezas e narrativas de autonomia e humanismo distantes e distintos de sua raiz psicossocial e econômica colonial. Embora o momento de luta por libertação, tenha gerado um alvo direto e outro causador dentre as alternativas disponíveis das interações, frisamos que ser não negro dispensa situações em que o indivíduo se sente coagido por sua condição de ser não negro, isto é, apenas pensa em ser; já o negro que em busca de uma subjetividade coesa realiza-se no silenciamento de sua negritude, no ser outro não negro. No entanto, esse passa a ser um caminho desintegrador, sempre frustrante, pois quanto mais se esforça, mais procura realizar o desejo capitalista do outro não negro, sua exploração aniquilante (FANON, 2008).

Wade Nobles (2013) nos lembra que esse processo diaspórico da violência para além da violência teria retirado do cenário cotidiano um ambiente para ser, pertencer e se tornar negro. Como resultado, teria ocorrido o que ele chama de desencarrilhamento, usando a metáfora da linha férrea como o trilho no qual o desenvolvimento psíquico precisa estar, inclusive negros. Se, para Nobles (2013), o desencarrilhamento é resultado desse processo de longa duração da escravidão, devemos relembrar a potência que subjaz o enegrecer de Petronilha Gonçalves da Silva (2011). Em outras palavras, o enegrecimento da educação, além de foco de resistência, é foco de afirmação da existência negra, similar ao quilombismo de Abdias do Nascimento (1989), e relembrado por Nobles (2013). Trazer a experiência da negritude é engendrar um ambiente psicossocial em que crianças, jovens, adultos e idosos se reconectem com a afirmação de seu pertencimento e reconhecimento, isto é, a plenitude de sua ancestralidade africana e a projeção de seus descendentes como cidadãos de direito e de fato. À medida que se reconstroem redes de apoio negros, na forma de coletivos como terreiros e irmandades em que a ancestralidade é experimentada enquanto estruturante e atualizada em movimentos, gestos, cânticos - isto é, axé -, é reatualizada a capacidade integradora matricentral de cuidado e acolhimento das aflições comunitárias.

Explicamos que, historicamente, as circunstâncias e desdobramentos das relações intersubjetivas dispuseram práticas sociais na afirmação de identidades coletivas patricentrais e matricentrais, ou inclusive mescladas. Por outro lado, foi a supremacia de práticas sociais patricentrais que tornaram a intimidade uma narrativa romântica para que o apreço à violência justificasse qualquer ato de domínio e exploração aceitável para uma consciência neutra - no caso de acontecer a esquiva aos elementos de sofrimento inoculados pela parcialidade das epistemologias não negras.

Ainda, à medida que se tem no cenário epistemológico o desvelamento das repetições patricentrais, estas que distanciam o foco da intimidade como elemento fundante da sociedade, mais coerente se pode dialogar com Carol Gilligan (1993) que questiona a postura de Lawrence Kohlberg, e com ele Weber, Freud e Piaget, sobre o desenvolvimento moral. Tendo sido assistente de Kohlberg, a autora pôde conduzir uma pesquisa com acadêmicas mulheres a respeito do aborto e desnudar que a questão está no parâmetro masculino (ou patricentral) de concepção moral (GILLIGAN, 1993).Esta concepção seria distante e fragmentada em prol de uma noção universal de ética, enquanto a mulher teria, por sua condição cognitiva e emocional, barreiras para esse tal patamar. No entanto, Gilligan (1993), inspirada nos estudos da psicanalista e feminista Nancy Chodorow (1978), concebeu que a mulher teria à sua disposição a experiência estruturante de proximidade com a mãe para integrarse nessa relação íntima. Assim, por sua capacidade de intimidade e proximidade, as preocupações morais não se deslocariam para um campo etéreo ou universal, mas para perto daqueles que estão a seu redor, pelos vínculos de intimidade. Podemos assim relembrar que essa reflexão reforça o que anteriormente Amadiume (1997) atestava enquanto sistemas disponíveis no cenário social. Por isso, a reflexão que nos possibilita Gilligan (1993) reforça o princípio primevo de criação e reprodução da humanidade a partir da experiência matricêntrica.

Nesse modo, podemos dar um passo adiante na reflexão sobre o desencarrilhamento de Nobles (2013), posto que o enegrecer poderia instituir 
afirmativamente o ser, pertencer e tornar-se negro. Tal processo caracterizaria a capacidade comunitária de parir um sentido compartilhado de ser coletivo. Nas comunidades de terreiro, por exemplo, a proximidade/pertencimento das pessoas negras transcende questões meramente econômicas, como asseverou Woortman (1987), mas segue o legado e a herança de ancestralidade, os laços de generosidade, de auxílio mútuo frente às dificuldades apresentadas no cotidiano como doenças, problemas familiares diversos, sobretudo, fala de uma demanda pelo acolhimento matricentral.

A coletividade nos terreiros e irmandades remonta a histórias das mulheres negras na organização e a responsabilidade por esses espaços. Se acusa que, muito antes das palavras de ordem e libertação de mulheres, ditas, universais (não-ameríndia e negra) pelo exercício de cidadania e trabalho, foram as mulheres negras que estiveram na resistência coletiva à escravização/colonização, com corpos e mentes violentados forçosamente dos seus pressupostos civilizatórios e epistemológicos, na tentativa de enquadrá-los ao modo eurocentrado (CARNEIRO, 2003; WERNECK, 2010). Em resposta, a coletividade negra forjou a resistência a partir da ancestralidade, da cultura, da comunidade. Nessa perspectiva, este ensaio traz fragmentos de duas pesquisas, sendo uma relacionada às práticas de benzedeiras (DIAS, 2019) e a outra sobre uma comunidade de terreiro (SANTOS, 2018), ambas do interior do Paraná, com vistas ao diálogo com a perspectiva afrocêntrica, para compreendermos os processos matricentrais de cuidado à aflição comunitária que foram difundidos a partir da África.

\section{O Terreiro Mamãe Oxum e Pai Ogum}

O terreiro Mamãe Oxum e Pai Ogum, situado em Irati-PR, desde o seu surgimento em 2010 é chefiado pela mãe de santo Dulce. Ela é a autoridade maior dentro do seu terreiro, assim como a sua mãe de santo, Dilma, cumpre tal papel no seu terreiro em Curitiba. Essas relações hierárquicas estão relacionadas à senioridade, correspondentes ao respeito à experiência (sabedoria) ancestral de anciãs e anciãos da comunidade. As pessoas ingressantes ao terreiro são recebidas por toda família de santo e são designadas pela mãe de santo para suas respectivas funções na comunidade, por isso é fundamental a participação em tais tarefas junto às pessoas mais velhas do culto, de forma que o aprendizado siga as regras da matriarca do santo, a Mãe Dulce.
Em resposta ao inatingível do psiquismo negro pelo etnocentrismo não negro, podemos lembrar com Fanon (2008, p.126) que esse enegrecer é a proposição comunitária de:

Apesar de tudo, recuso com todas as minhas forças esta amputação. Sinto-me uma alma tão vasta quanto o mundo, verdadeiramente uma alma profunda como o mais profundo dos rios, meu peito tendo uma potência de expansão infinita. Eu sou dádiva, mas me recomendam a humildade dos enfermos [...]”.

Assim, mesmo que com o enegrecimento ancestral de Mãe Dulce tenha sido repassado pela Mãe Dilma e pelo falecido Pai Luís, a vivência de sua filiação deu o molde para que o seu terreiro reflita sua experiência de acolhimento. De outra maneira, o tornar-se negro não se traduz em um único caminho, mas, diante da alteridade desdobra-se na generosidade da resposta às aflições comunitárias. Tal constituição subjetiva na cosmovisão afrocêntrica é construída, também, pelos arquétipos ancestrais ligados aos orixás regentes de cada ori (cabeça). No caso da Mãe Dulce, trata-se do orixá Oxum. Como a memória coletiva consegue dar o sentido comunitário para a eficácia dessa reestruturação intersubjetiva e ancestral, a comunidade explica a função primordial da Mãe Dulce, contando que, logo que todos os orixás chegaram à terra, organizaram reuniões restritas, exclusivamente, masculinas. Oxum, aborrecida por não poder atuar nas reuniões e nas deliberações, resolve se vingar, tornando estéreis todas as mulheres, secando as fontes, deixando assim a terra improdutiva. Mas à medida que Oxum retoma sua participação ativa e plena na comunidade a fecundidade do cosmos é retomada. Oxum é chamada de "Yialodê", título dado à pessoa que ocupa o lugar mais importante entre as mulheres da cidade (ARAÚJO, 2017), assim como é o cargo da Mãe Dulce no terreiro.

As relações da Mãe Dulce com a comunidade ressaltam a intimidade ancestral, sobretudo do cuidado maternal, pois ela é responsável pela proteção espiritual de cada filho. Essa dimensão diz respeito não só ao que ocorre dentro do terreiro, mas à vida pessoal nos aspectos familiares, de saúde, afetivos, de trabalho e estudo, entre outros. A Mãe Dulce se intitula como mãe coruja, e afirma: "gosto de saber como estão meus filhos e, fico muito braba quando eles estão precisando de alguma coisa e não me avisam, ao contrário pedem ajuda de terceiros" (SANTOS, 2018). Ela acrescenta que o crescimento espiritual depende do curso da vida em 
geral, "às vezes acontece uma coisa lá fora, por exemplo, brigas no relacionamento e a mãe não sabe, não espere para contar, venha que a mãe aconselha, passa uns banhos e limpeza para ir acalmando" (SANTOS, 2018).

$\mathrm{Na}$ lógica da matricentralidade, a maternidade, portanto, descreve a natureza das responsabilidades comunitárias envolvidas na criação dos filhos e no cuidado dos outros, ou seja, é exercido tanto por homens como por mulheres (DIOP, 2014). No terreiro de religiões afro-brasileiras, a matricentralidade é encontrada nas relações da matriarca ou do patriarca com seus filhos de santo, a partir do cuidado na transmissão das tradições do sagrado que constrói a ligação coletiva com a ancestralidade. A importância do exercício do cuidado matricental nessas lideranças comunitárias se evidencia com a lembrança de um filho-de-santo, cuja memória do falecido avô de santo, Luís, é tido pela comunidade como guardião da ancestralidade, visto que ele "tinha uma sabedoria sem limites, contava os mitos e tirava qualquer dúvida com uma bondade incrível, para ele não existia pergunta boba, falava sem cansar, a partir da sua grande experiência" (Pai pequeno F.). Por isso, devemos entender que a generosidade é autocriadora a partir do acolhimento da alteridade, pela capacidade de responder ao cuidado comunitário pela proximidade ancestral.

Na pesquisa de Cristina Tramonte (2001) a respeito dos processos de aprendizagens interculturais no contexto das famílias de santo, a Yalorixá Teresa afirma que a tarefa das mães-de-santo, ao colocarem um médium para desenvolver, exige cuidado como se fosse um bebê: dar-lhe toda a atenção até que ele vai se cuidando, se formando e não precise mais de tanto zelo. Lembra que na parte espiritual, da mesma forma que precisa de palavras amorosas, quando necessário é preciso uma palmadinha (TRAMONTE, 2001).

Nessa perspectiva são construídas relações pautadas na matricentralidade - de cuidado, afeto, confiança, compromisso, respeito e proximidade - (DIOP, 2014), o que garante as aprendizagens no grupo do terreiro (DA SILVA, 2016; 2019). Um dos pais pequenos do terreiro, cargo hierárquico abaixo da mãede-santo, relata que inicialmente se agrupou com amigas(os) que também não tinham experiências com as práticas relativas ao santo e realizavam trabalhos religiosos em uma garagem da residência de uma delas. Na época, desconheciam fundamentos, careciam de uma liderança e um acompanhamento adequado para a realização dos cultos. Mais tarde, a experiência no terreiro Mamãe Oxum e Pai
Ogum serviu de fronteira para suas aprendizagens na construção umbandista, em contraste com as outras práticas por ele realizadas anteriormente.

Essas aprendizagens são formadas por saberes tradicionais e saberes reatualizados, transmitidos entre os integrantes do grupo consciente ou inconscientemente. Este compartilhamento de saberes gera aprendizados coletivos, que por sua vez serão transmitidos ou modificados pelo grupo de acordo com a demanda encontrada, gerando um novo sinal que o grupo toma para si. Cada grupo apresenta uma bagagem cultural, mas na fronteira só se busca o que é operativo para servir ao contraste (CUNHA, 2009).

A importância de vislumbrar esses valores na vivência umbandista se encontra no destaque aos saberes tradicionais que lhe dão forma, mas que historicamente foram invisibilizados pela epistemologia eurocêntrica. Reconhecer a complexidade do universo simbólico afro-brasileiro umbandista nos dá acesso a conhecimentos e suas manifestações comunitárias, que desconstroem o imaginário colonial racista, principalmente sobre uma África estereotipada e seus desdobramentos no Brasil, como aponta Nilma Lino Gomes (2002).

O corpo imbuído pela ancestralidade africana identifica uma corporeidade diaspórica, como afirma Azoilda Trindade (2005). Tal processo de consciência desse corpo, para além das conformações que lhes são conferidas pelo racismo, pelo machismo e pela colonialidade, retoma sua potencialidade de fala, de acordo com Fanon (2008, p. 33): "Falar é existir absolutamente para o outro".

\section{Irmandade das Benzedeiras}

Inserido nesta perspectiva de generosidade matricentral, incluímos os cuidados comunitários presentes na prática do ofício das benzedeiras no território brasileiro (OLIVEIRA, 1984). As práticas do ofício do benzimento possuem traços de aprendizagens matricentrais que demonstram a resistência e a generosidade dessas mulheres onde residem, cuidando, acolhendo, tratando e aconselhando mesmo os não negros pertencentes às suas comunidades.

Mesmo diante do desprezo hegemônico, do racismo estrutural e institucional religioso, as benzedeiras formam irmandades de cuidado com o outro e autocuidado, transmitindo seus saberes tradicionais matricentrais, pois “a solidariedade africana 
não é uma solidariedade científica, sendo esta tão eficaz quanto desprovida de calor humano" (DIOP, 2014, p. 174). As aprendizagens são vivenciadas e transmitidas através do ofício, de mulheres para aprendizes, no decorrer do tempo, e possuem fortes traços do sincretismo religioso ocorrido no território brasileiro entre religiões de matriz africana, a pajelança e a igreja católica.

No perímetro urbano do município de Foz do Jordão, no Paraná, no ano de 2018 havia vinte e cinco mulheres desenvolvendo o ofício do benzimento (DIAS, 2019). Essas mulheres instituíram, no decorrer do tempo, suas próprias regras de atendimento e transmissão do dom, pautadas sobretudo na reciprocidade ternária (MAUSS, 2011), a qual zela pelo bem comum. A reciprocidade ternária pressupõe ações de reciprocidades indiretas em contraposição às binárias que seriam diretas. As relações que se fundam em tais estruturas de reciprocidade ternárias geram valores materiais ou instrumentais imateriais (conhecimentos, informações, saberes), além de produzirem também valores afetivos (proximidade, amizade) e valores éticos (confiança, equidade, justiça, responsabilidade).

Existe um elo entre comunidade, doenças e benzedeiras que ultrapassa o que a ciência trata como cura, como cita Alain Caillé (2014, p. 43): "é evidente que não se pode curar alguém apenas com ciência e técnica”. São as relações, as trocas, as vivências que determinam esses laços dos quais cada indivíduo concebe a cura. Através das vivências comunitárias dessas mulheres e das diversas relações que as permeiam, tornam-se visíveis os processos de aprendizagem relativos ao ofício do benzimento. Aprendizagens comunitárias mantidas no acolhimento de aflições, isto é, na resposta espiritual à angústia daqueles que as procuram por gerações.

O conhecimento das benzedeiras acerca das ervas, chás, rezas, simpatias, parto e garrafadas provém da intimidade de seu aprendizado com suas anciãs, do compartilhar seu cotidiano. Nesse acolhimento das aflições, suas casas se tornam um portal pelo qual transmite-se a generosidade ancestral que se perpetua em uma rede de apoio familiar, comunitário e de irmandade.

As benzedeiras dominam o território da casa. Esse território, por sua vez, se subdivide entre os espaços ocupados para atendimento e espaço comum familiar, dentro do qual as benzedeiras são autoridades que organizam, coordenam e curam. A notoriedade de sua generosidade é espalhada por essas respostas às alteridades comunitárias, assim como pelos diferentes vínculos de suas consulentes.
Logo, o processo psicoeducativo do benzimento pôde ser compreendido por intermédio da interdependência da dádiva, reciprocidade, matricentralidade e ancestralidade. As benzedeiras evidenciam, através de suas práticas, que a perpetuação de determinados saberes de uma forma silenciada caracteriza os desdobramentos de resistências diante do desprezo patriarcal, capitalista e racista. Por isso, esse processo contínuo de produção de bem-estar comunitário pela prática de benzimento, pela experiência comunitária no entorno das ações desse grupo de benzedeiras e benzedores (cujo dom não pode ser transferido), por meio da irmandade e da generosidade, transmitem e perpetuam os saberes ancestrais de acolhimento e cuidado comunitário. Apresentam, por suas atitudes de cuidado coletivo, práticas culturais imemoriais, orquestrando na relação familiar a perpetuação do aprendizado que se produz e reproduz no reconhecimento diário da comunidade. Posto que, a seu turno, a experiência do benzimento, do curar e ser curado - a generosidade do acolhimento da alteridade - como resposta às aflições comunitárias reencarilha o pertencimento negro por essas atitudes negras ancestrais, mesmo que silenciada nas instituições sociais.

\section{Considerações finais}

Procuramos demonstrar que as aprendizagens negras sobre o cuidado comunitário, a partir da África, potencializaram a capacidade humana em agregar e cuidar de si enquanto comunidade. Esses ensinamentos matricentrais de acolhimento à alteridade foram difundidos pela expansão humana. Mesmo com toda a violência colonial, que ao longo dos séculos buscou despersonificar a humanidade negra, ela não foi suficiente para fazer compreender a potencialidade de sua generosidade ancestral.

Embora a diáspora ainda seja traumática, à medida que o negro procura realizar-se pelo desejo de um outro não negro, ou sobreviver à exploração e à violência para além da violência, como Nobles (2008) retratou pelo desencarrilhamento, propusemos levar a cabo aquilo que o autor já havia anunciado. Em sua leitura de Abdias do Nascimento (1989), Nobles (2008) considerou o enegrecimento em sua correspondência ao ser, pertencer e se tornar negro. Ora, esse processo em nossa perspectiva retrataria a ancestralidade 
matricentral do cuidado e acolhimento ao qual se referiu Diop (2014) no Berço Meridional. Mesmo que universal, Amadiume (1997) nos demonstrou que durante os longos processos sócio-históricos se mantiveram disponíveis nos cenários africanos os sistemas matricentral e patricentral. Conquanto, no Brasil, similarmente encontramos essas aprendizagens matricentrais que traduzem a generosidade do cuidado comunitário em terreiro de umbanda e irmandade de benzedeiras no Centro-Oeste do Paraná.

Logo, temos disponíveis exemplos em que o enegrecimento se faz presente nas respostas negras às aflições comunitárias, que afirmam o acolhimento para a autocriação e abundância do humano em sua relação íntima de pertencimento ancestral.

\section{Referências}

AMADIUME, Ifi. Reinventing Africa - matriarchy, religion and culture. Londres, Nova Iorque: Zed Books, 1997.

ARAÚJO, Juliana Leandro de. Obínrin: Yabás, suas joias e adornos contemporâneos: coleção inspirada nos principais orixás femininas. 2017. 71f. Trabalho de Conclusão de Curso (Graduação inspirada nos principais orixás femininas. 2017.71f. Trabalho de Conclusão de Curso (Graduação
em Design de Produto) - Universidade Estadual Paulista Júlio de Mesquita Filho, Bauru, SP, 2017.

AVPH - ATLAS VIRTUAL DE PRÉ-HISTÓRIA. USP, 2019. Disponível em: http://www.avph.com. br/orrorintugenensis.htm. Acesso em: 2 jul. 2019.

CAILLÉ, Ailan. Dádiva, Care e Saúde. Sociologias, Porto Alegre, v. 16, n. 36, p. 42-59, mai./ago. 2014. Disponível em: http://www.scielo.br/pdf/soc/v16n36/1517-4522-soc-16-36-0042.pdf. Acesso em: 30 out. 2018.

CAMPBELL, Joseph. As máscaras de Deus - Mitologia Primitiva. Vol. 1. Rio de Janeiro: Palas Athena, 1992. CARNEIRO, Sueli. Enegrecer o feminismo: a situação da mulher negra na América Latina a partir de uma perspectiva de gênero. In: ASHOKA EMPREENDIMENTOS SOCIAIS; TAKANO CIDADANIA (Orgs.). Racismos contemporâneos. Rio de Janeiro: Takano, 2003. p. 49-58.

CHODOROW, Nancy. The reproduction of mothering. Berkeley: University of California Press, 1978. CUNHA, Manuela Carneiro da. Cultura com aspas e outros ensaios. São Paulo: COSACNAIFY, 2009.

DA SILVA, Jefferson Olivatto da. Aprendizagens comunitárias africanas de longa duração e em larga escala segundo a expansão banta. Revista Relegens Thréskeia, Curitiba, v. 05, n. 1, p. 84-107, jun. 2016. Disponível em: https://revistas.ufpr.br/relegens/article/view/45660. Acesso em: 05 jul. 2019.

Comportamentos sociais de longa duração em centros umbandistas do sul paranaense. In: HERTZ, Wendel. Umbanda, cultura e comunidade: olhares e encruzilhadas. Londrina: Syntagma, 2019. p. 180-198. Disponível em: http://www.syntagmaeditores.com.br/Livraria/ Book?id=1061. Acesso em: 13 ago. 2019.

DA SILVA, Petronilha Gonçalves. Entre Brasil e África: construindo conhecimentos e militância. Belo Horizonte: Mazza, 2011.

DIAS, Márcia Denise de Lima. Benzedeiras: a educação de resistência femininas de mulheres negras pelas ervas. 102f. Dissertação (Mestrado em Educação) - Universidade Estadual do Centro-Oeste - UNICENTRO, Guarapuava, 2019.
DIOP, Cheikh Anta. A unidade cultural da África negra. Esferas do patriarcado e do matriarcado na Antiguidade Clássica. Luanda, Angola: Edições Mulemba; Ramada, Portugal: Edições Pedago, 2014.

FANON, Frantz. Os condenados da terra. Rio de Janeiro: Civilização Brasileira, 1968.

_. Pele negra, máscaras brancas. Salvador: EDUFBA, 2008.

GILLIGAN, Carol. In a difference voice: psychological theory and women's development. Cambridge: Harvard University Press, 1993.

GOMES, Nilma Lino. Trajetórias escolares, corpo negro e cabelo crespo: reprodução de estereótipos ou ressignificação cultural? Revista Brasileira de Educação, Rio de Janeiro, n. 21, p. 40-51, ou ressignificação cultural? Revista Brasileira de Educação, Rio de Janeiro, n. 21 , p. 40-51,
dez. 2002 . Disponível em: http://www.scielo.br/ scielo.php?script=sci_arttext\&pid=S141324782002000300004\&lng=en\&nrm=iso. Acesso em: 13 jun. 2019.

MARTINS, Ovídio de Souza. As cabras eninaram-nos a comer pedras para não perecermos. In: MEDINA, Cremilda de Araújo. Sonha Mamana África. São Paulo: Epopeia, 1987. p. 463-478.

MAUSS, Marcel. Sociologia e antropologia. São Paulo. CosacNaify, 2003. Disponível em: https://edisciplinas.usp.br/pluginfile.php/3012986/mod_resource/content/0/ Mauss_Marcel_ Sociologia_e_antropologia_2003.pdf. Acesso em: 10 abr. 2017.

M’BOKOLO, Elikia. África negra - história e civilizações. Tomo I (até o século XVIII). Salvador: EDUFBA; São Paulo: Casa das Áfricas, 2009.

NASCIMENTO, Abdias. Brazil mixture or massacre: essays of genocide of a black people. Dover: Majority Press, 1989.

NNAEMEKA, Obioma. Nego-Feminism: theorizing, practicing, and pruning Africa's way. Signs: Journal of Women in Culture and Society, v. 29, n. 2, p. 357-385, 2003.

NOBLES, Wade. Shattered consciousness and fractured identity: The lingering Psychological Effects of the Transatlantic Slave Trade Experience. In: Trans-Atlantic Slave Trade Commission Report I. Chicago: Jacob H. Carruthers Center for Inner City Studies, Northeastern Illinois University, 2008.

. Natural/man-made disaster and the derailment of the African worldview. Journal of Black Psychology, v. 39, n. 3, p. 252-256, 2013.

OLIVEIRA, Elda Rizzo de. O que é medicina popular. São Paulo: Brasiliense, 1984.

RICHARDS, Andrey. Chisungu: a girl's initiation ceremony among the Bemba of Northern Rhodesia. London: Longman: 1956.

SANTOS, Thais Rodrigues dos. Constelações de aprendizagem nas práticas da umbanda no terreiro Mãe Oxum e Pai Ogum. 139f. Dissertação (Mestrado em Educação) - Universidade Estadual do Centro-Oeste - UNICENTRO, Guarapuava, 2018.

TRAMONTE, Cristiana. Com a bandeira de Oxalá: trajetórias, práticas e concepções das religiões afro-brasileiras na Grande Florianópolis. 2001. Tese (Doutorado Interdisciplinar em Ciências Humanas) - Universidade Federal de Santa Catarina, Florianópolis, 2001.

TRINDADE, Azoilda Loretto. A formação da imagem da mulher negra na mídia. 282f. Tese (Tese de Doutorado). Universidade Federal do Rio de Janeiro, Rio de Janeir, 2005.

WERNECK, Jurema. Nossos passos vêm de longe! Movimentos de Mulheres Negras e Estratégias Políticas contra o sexismo e o racismo. Revista da ABPN, v.1, n.1, p. 07-17, mar./jun. de 2010.

WOORTMANN, Klaas. A família das mulheres. Rio de Janeiro: Tempo Universitário, 1987. 
URBANIZAÇÃO E RESISTÊNCIA NA ÁFRICA CONTEMPORÂNEA: ITINERÁRIOS DA OCUPAÇÃO URBANA E A COLONIZAÇÃO EM CABO VERDE

Rutte Tavares Cardoso Andrade

O processo de urbanização e de expansão urbana assumem contornos específicos no contexto da África Contemporânea, tendo em vista que grande parte das cidades africanas, como a cidade da Praia, capital de Cabo Verde, foi erguida dentro de um contexto de dominação e de exploração colonial. As cidades não foram concebidas e/ou planejadas para acolher o povo africano, e sim para abrigar as elites que compunham a administração colonial. A configuração geográfica e arquitetônica das cidades africanas demonstra uma cultura de hierarquização e de segregação social e espacial. As elites dominantes do colonialismo viviam em áreas planejadas e urbanizadas com infraestruturas, bens e serviços importantes dentro da cidade, ao passo que os(as) escravizados(as) e seus descendentes eram relegados para os espaços concebidos como suburbanos, dentro do contexto do sistema de dominação colonial. Os(as) africanos(as), corpos negros na condição do não-ser no sistema de dominação colonial eurocêntrico, não eram considerados dignos(as) de viver no centro urbano, pela condição de sub-humanos ou seres inferiores (FANON, 2006).

O presente artigo é o resultado parcial de uma pesquisa de campo sobre o processo de ocupação do espaço urbano no contexto da África, a partir de observação in loco realizada na cidade da Praia, capital de Cabo verde, sob o olhar da contemporaneidade, situando o contexto histórico no qual se desenvolveu esse processo. A ocupação do espaço urbano na informalidade habitacional está presente na história da cidade da Praia, capital de Cabo Verde, e representa um aspecto marcante da sua paisagem cotidiana desde o período colonial. Apesar do esforço das instituições de matriz colonial em punir e disciplinar as práticas de informalidade habitacional, a partir da imposição de regulamentações e de normas higiênico-sanitárias, isso não significou o fim deste tipo de ocupação do espaço urbano. Elas continuam presentes no cenário urbano da cidade da Praia e nem sempre seguindo as regulamentações traçadas pelo Estado. Deste modo, existe um conjunto específico de práticas culturais de matriz civilizatória africana que tiveram importância em épocas anteriores, com um peso social significativo na formação e configuração das cidades africanas.

Existe uma forte tradição de ocupação de espaço e informalidade habitacional, que remonta ao período colonial, no início da formação da cidade da Praia, em Cabo Verde. Na cidade da Praia existem heranças dos aspectos que remontam ao período escravagista e colonial. A análise desta pesquisa será conduzida a partir da seguinte questão: em que medida as experiências, saberes e práticas sociais de ocupações urbanas informais que remontam desde o período escravista e colonial, têm sido mantidas, adaptadas e/ou transformadas no processo de ocupação do espaço na cidade da Praia? Nesse sentido, a partir da epistemologia afrocêntrica, importa questionar o modelo de urbanização vigente na África e, mais especificamente, em Cabo Verde. No âmbito do quadro apresentado nesta pesquisa, busca-se, de forma reflexiva, compreender o cotidiano de ocupação do espaço urbano na informalidade habitacional na África Ocidental, a partir da cidade da Praia, em Cabo Verde. Para isso, precisamos remontar aos contextos históricos anteriores, nos quais se vem desenvolvendo essa prática social, bem como analisar as experiências dos atores sociais relacionadas às suas histórias de vida e resistência, no esforço de ter acesso à casa própria e viver na cidade.

Definimos um grupo de interlocutores(as) e no interior deste selecionamos seis, sendo dois homens e quatro mulheres cabo-verdianas(os), provenientes do interior das ilhas de Santiago e do Fogo, atualmente moradoras(es) do bairro de Jamaica ${ }^{87}$, na cidade da Praia, em Cabo Verde. A escolha por utilizar um maior número de mulheres nesta amostragem esteve pautada pelo interesse em compreender e contrastar o papel social das mulheres africanas, observando sua agência e protagonismo na formação da cidade, além de uma releitura da $87 \quad$ Jamaica é um dos bairros mais recentes da cidade da Praia, capital de Cabo Verde. É um subúrbio jovem, situado entre os bairros de Achada Grande Frente e Achada Mato, numa ladeira árida, com pouca vegetação e sujeita a enxurradas e desabamentos de terras em tempos de chuvas intensas, representando riscos à vida dos moradores da comunidade. Com uma área de cerca de $0,37 \mathrm{Km} 2$, Jamaica situa-se também nas proximidades da antiga instalação do aeroporto da Praia, hoje funcionando como sede do Serviço Nacional de Proteção Civil 2010), esse bairro possú́ una populaç̃o de 227 habitantes, com tendência para un crescimento rápido, uma vez), esse bairro possula uma população de 227 habitantes, com tendència para um crescimento rapido, uma vez que, com grande frequência, a comunidade é ocupada por novos assentamentos "clandestinos" para repro-
duzir a linguagem da autarquia local e da mídia cabo-verdiana. Os assentamentos situam-se nas encostas e ribeiduzir a linguagem da autarquia local e da mídia cabo-verdiana. Os assentamentos situam-se nas encostas e ribeiras, sem as mínimas condições de habitabilidade, quais sejam portas e janelas seguras, cômodos independentes,
telhado compatível com o clima quente do arquipélago de Cabo Verde, e banheiros sanitários condignos. Grande telhado compatível com o clima quente do arquipélago de Cabo Verde, e banheiros sanitários condignos. Grande parte das habitações são construídas com blocos de concreto, lata, plásticos e papelão, sem nenhuma segurança. nal africano de construção de habitação que ainda existe no interior das ilhas de Cabo Verde (ANDRADE, 2018). 
Deste modo, a representação da cultura africana na formação do espaço

ancestralidade africana, no contexto social com forte influência do patriarcado, atravessado pelo processo de escravização e colonização. Nesta pesquisa, pautamos pela abordagem metodológica afrocêntrica, de Molefi Kete Asante (2009, p. 94), enfatizando a proposta do "mulherismo africana" enquanto paradigma interpretativo da identidade africana. Trata-se de uma epistemologia pan-africana e afrocentrada, que realça o papel da agência em caracterizar as mulheres africanas como protagonistas na resistência para recuperar, reconstruir e criar a integridade cultural africana, no continente e na diáspora. Assim, os princípios ancestrais de reciprocidade, equilíbrio, harmonia, justiça, liberdade e ordem devem fazer parte também da epistemologia do "mulherismo africana", à semelhança da teoria afrocêntrica (ANDRADE, 2018).

\section{Sistema de Dominação Colonial e Urbanização em Cabo verde}

Nos últimos cinco séculos, as sociedades ocidentais produziram processos de dominação sobre o continente africano que resultaram no colonialismo europeu na África, no escravismo criminoso nas Américas e no mercantilismo e capitalismo na Europa (RODNEY, 1972. Nesse sistema de imposição de modelo civilizatório, ideologias foram produzidas, sendo uma delas o eurocentrismo, resultando na hegemonia cultural europeia sobre africanos(as) no continente e na diáspora. Esse embate entre as culturas tem como base as lutas políticas, econômicas, sociais e culturais entre os povos e descendentes de povos desses dois continentes.

No entanto, a cultura europeia se impôs como um modelo dotado de caráter universal, estruturada por um pensamento científico e consagrando a Grécia como o berço da civilização. Qualquer análise mais cuidadosa da história da humanidade pode constatar que a Grécia não tem essa dimensão que é dada no ocidente. A força da hegemonia cultural ocidental levou a um apagamento e exclusão das civilizações africanas no mundoocidental, e das culturas delas resultante nas Américas (ASANTE, 2009). Em Cabo Verde, o sistema de dominação colonial determinou uma disputa de poder político em torno das culturas, o que levou à sub-representação da cultura endógena, concebida como folclórica, e uma supervalorização da cultura europeia, resultando mesmo assim em um constante movimento de resistência e afirmação dos padrões e sistema cultural africanos. urbano da cidade da Praia é consequência dessa resistência cultural. Em função da cultura africana ser vista sempre como oposição à cultura hegemônica é que existe a necessidade de defini-la, e de elaborar conceitos para sua representação. Para uma definição histórica de cultura, faz-se necessário reconhecer que os seres humanos são coletivos, vivem e formam coletividades humanas, a exemplo das cidades. As culturas africanas, heterogêneas na sua composição, transportam conhecimentos milenares, ricos e complexos, transmitidos de geração a geração, ressignificados, nas estratégias de resistências, e atualizados no cotidiano do povo africano, no continente e na diáspora. Essa matriz civilizatória africana está subjacente ao modus vivendi do povo africano, sobretudo na disputa do espaço urbano e nas tentativas de construção de suas habitações, na contramão da legalidade estabelecida pela instituição pública de matriz colonial.

Dentro da cultura hegemônica ocidental, as definições de cultura e sua aplicação ao conhecimento ficam dificultadas pela ideologia eurocêntrica, pois estas funcionam como máscara aos processos de dominação e realização da naturalização da hegemonia ocidental. A cultura de cada povo passa a ser vista pela possibilidade em registrar e compreender a experiência humana como processo civilizatório e não apenas na experiência humana em si e no seu legado.

Como faz notar Molefi Asante (2009), na Antiguidade, as sociedades africanas tiveram um grande acúmulo de experiências civilizatórias na região do vale do Rio Nilo, através de povos conhecidos na histórica como etíopes, núbios e egípcios. As culturas desses povos constituem um legado comum que se expandiu e diversificou através de todo o continente africano ao longo dos tempos históricos que se sucederam. A essa base comum das sociedades antigas do vale do Rio Nilo denominou-se como africanidade e às culturas produzidas, como a diversidade da africanidade (DIOP, 1981; OBENGA, 1990. ASANTE, 2009). As culturas africanas na diáspora e no continente, apesar da diversidade, possuem um eixo comum. A cultura africana na atualidade é definida como uma diversidade de culturas desenvolvidas a partir daquela emergente do vale do Rio Nilo, conhecida como cultura Kemética (egípcia). Existe uma unidade cultural na diversidade africana (DIOP, 1990).

A cidade da Praia, capital de Cabo Verde, foi fruto do projeto colonial; e foi transposta às ideologias e princípios culturais inerentes à dinâmica civilizatória 
europeia ${ }^{88}$. Esse projeto colonial expressa na profunda segregação e disparidade sociais, resultantes do materialismo, individualismo, xenofobia, patriarcado, racismo estrutural, propriedade privada de terra, entre outros (DIOP, 1981. Muitas cidades africanas erguidas durante e depois das independências são expressão da cultura europeia, no esforço de excluir e invisibilizar a cultura africana. Esforço esse que se traduz, muitas vezes, na resistência do povo africano, em busca do direito à cidade e à identidade cultural. No caso da cidade da Praia, o movimento mais visível é o da insubordinação, no que respeita à lei da urbanização, resultante da discrepância entre as necessidades e prioridades do povo africano e do pequeno grupo hegemônico.

Podemos pensar que a cidade seja a expressão máxima da cultura, apresentando seus edifícios, moradias, monumentos, as expressões da arte, os lugares das suas manifestações, bem como os espaços de produção e transmissão de conhecimentos nas escolas, universidades e museus, tendo também os escritórios, locais de comércio, em suma, a história acumulada no tempo. Assim, a cidade expressa as relações de poder e de "cosmossensação" (OYEWUMI, 1997) do povo africano, que em uma utopia de democracia representa todos os grupos humanos da sociedade, expressando também a cultura cabo-verdiana.

\section{Urbanização na África Contemporânea: o Caso de Cabo verde}

A cidade da Praia, capital de Cabo Verde, abriga as principais instituições públicas e privadas do país. No contexto cabo-verdiano, a cidade da Praia se apresenta como o principal destino para a procura de trabalho e formação acadêmica por parte das pessoas de baixa renda provenientes do meio rural da ilha de Santiago, onde se encontra localizada, e das outras ilhas que compõem o arquipélago de Cabo Verde, sobretudo ilhas periféricas, como Maio, Fogo e Brava. Nesse sentido, a vinda para a cidade da Praia, capital do país, nem sempre traduz o imaginário desses migrantes que chegam repletos de necessidades e

$88 \quad$ O berço do Norte, confinado na Grécia e Roma, é caracterizado pela família patriarcal, pelas cidades-estados (houve entre estas duas cidades, disse Fustel de Coulanges, algo mais intransitável do que uma montanha); é fácil ver, no contato com o mundo do sul, que os nortistas ampliaram sua concepção de estado, elevando-se à ideia de estado territorial e imperio. As caracteristicas particulares destas cidades- estado, fora das quais o homem era um fora da lei,
desenvolveu um patriotismo interno, bem como a xenofobia. Individualismo, solidão moral e material, desgosto pela desenvolveu um patriotismo interno, bem como a xenofobia. Individualismo, solidão moral e material, desgosto pela existência, tudo isto é objeto da literatura moderna, a qual, mesmo nos aspectos filosóficos não é nada mais do que a
expressão da tragédia do modo de vida dos ancestrais arianos, todos atributos deste berço. Um ideal de guerra, violência expressão da tragédia do modo de vida dos ancestrais arianos, todos atributos deste berçco. Um ideal de guerra, violência,
crime e conquistas herdados da vida nômade, que tem como consequência o sentimento de culpa e pecado original crime e conquistas herdados da vida nômade, que tem como consequência o sentimento de culpa e pecado original, o expectativas, mas acabam se frustrando com os problemas estruturais, específicos das cidades concebidas a partir do projeto colonial, para atender as demandas políticas e econômicas, específicas do sistema hegemônico capitalista. A maior frustração refere-se à violência física e simbólica com que os novos moradores da cidade vivenciam, nomeadamente, problemas da habitação condigna, acesso à água potável e a vários outros produtos indispensáveis à sua subsistência e sobrevivência na cidade grande.

A tradição de ocupação de espaço e informalidade habitacional remonta ao período colonial, no início da formação da cidade da Praia. Os estudos indicam que a ocupação do espaço urbano e suas configurações iniciais caracterizaram-se pela presença de homens, posteriormente, pelos seus descendentes, que se reuniam em áreas não planejadas da cidade, construindo suas casas na informalidade. As áreas urbanas onde construíam as suas casas eram marcadas por práticas de sua cultura de origem, ainda que em contexto diferente e em condições sociais quase sempre adversas.

Desde o início da formação da cidade da Praia, a ordenação do espaço urbano tem se baseado em concepções ocidentais de pensamento, assumindo configuração e imagem de urbanização imposta pela elite colonial. Após a independência nacional, ocorrida em 1975, essa prática de exclusão e de segregação continuou a ser reproduzida pela nova elite dominante cabo-verdiana. Esse modelo de urbanização não se coaduna com a lógica de ocupação do espaço urbano das pessoas de baixa renda, que se estrutura tanto pela forma particular determinada pela cultura africana, como pela condição de dominação e exploração a que os africanos foram submetidos durante a vigência do escravismo em Cabo Verde (ÉVORA, 2009).

A ocupação do espaço na informalidade habitacional, na Praia, apesar de constituir elemento vital para o funcionamento da cidade, foi recorrentemente conotada de contribuir para práticas ilícitas e "costumes incivilizados". Tal "incivilidade" foi quase sempre associada aos usos e costumes africanos. Desse modo, foram implementados mecanismos para coibir homens e mulheres de ascendência africana à construção de casas em áreas não urbanizadas da cidade. À medida que o processo de urbanização da cidade da Praia foi se modernizando, aboliram-se costumes e práticas de construção genuinamente africanas, tais 
como casas de pedra e barro com coberturas de palha, tradição essa considerada "incivilizada" e fora do padrão ocidental europeu.

Perante essas circunstâncias, o processo de ocupação do espaço urbano na informalidade habitacional passou a representar um fator de conflito entre as pessoas de baixa renda e o poder público, já que o espaço urbano representava o fator de inclusão e exclusão e, simultaneamente, de hierarquização social. Inclusão porque, embora a cidade da Praia fosse uma sociedade caracterizada por profundas desigualdades e exclusões sociais que implicavam uma multiplicidade de formas de conflitos e de ação social, tinha a ocupação do espaço na informalidade como representativo de uma das principais formas de territorialização negra.

Desse modo, transformar e reinventar os papéis que lhe estavam atribuídos consecutivamente na estrutura social da sociedade escravista-colonial e, posteriormente, nas pós-coloniais, tornou-se um modo dessa maioria silenciada, desafiar a ordem social estabelecida pelo poder público. Foram desenvolvidas, ao longo do tempo, as identidades ou seja, aquelas criadas por pessoas que se encontram em posição e condições estigmatizadas ou desvalorizadas pela lógica da dominação, construindo a estratégia de resistência e subsistência, com base em princípios diferentes dos que permeiam as instituições ou até mesmo opostos a elas.

Conforme Semedo (1998), a estrutura urbana que a cidade da Praia adquiriu com o tempo, pela habitação informal, diz respeito tanto à resistência de pessoas de baixa renda quanto à permanência de um conjunto diferenciado de ocupações, nos mais diversos bairros da cidade, ao longo do tempo, que carregam a marca e o estigma da contravenção e da legalidade na estruturação do espaço urbano. Consequentemente, os efeitos foram nefastos sobre a forma como são reconhecidas socialmente as suas contribuições e as suas participações na construção social e cultural da cidade africana num contexto de sistema de dominação colonial.

Demostrando alguma aproximação entre as práticas socioculturais de urbanização na África e na diáspora, autores de referência em estudos sobre o urbanismo africano asseguram que a tradição de autonomia das mulheres que se dedicam à construção de casas, assim como seu papel social relevante, não é uma prática circunscrita apenas à experiência da diáspora. Antes disso, alguns autores apontam que as práticas através das quais as(os) africanos(as) buscam construir as suas casas têm paralelo com as soluções adotadas em regiões do continente africano intimamente ligadas à ancestralidade africana (VERGER; BASTIDE, 1992).

No caso específico de Cabo Verde, o esforço dos governos para promover habitação e trabalho para todos tem se revelado ineficaz, visto que a maioria das pessoas vive em assentamentos informais, com todas as suas consequências e/ou implicações sociais, ou seja, uma urbanização que não atende às necessidades de povo africano. Assim, o fenômeno da expansão urbana em Cabo Verde particularmente, e no contexto africano em geral, constitui um dos maiores problemas do desenvolvimento em África, visto que grande parte das pessoas nas periferias urbanas tem dificuldade no acesso aos serviços básicos, como a saúde, educação, água potável, saneamento, eletricidade, transporte, entre outros. Nesse sentido, a questão da informalidade habitacional tornase um fenômeno crucial para o desenvolvimento das cidades africanas.

\section{Itinerários Ocupacionais e Experiências Vividas}

O trabalho de campo foi realizado entre 2016 e 2017, com o objetivo de conhecer e analisar o cotidiano das pessoas de baixa renda, além de compreender o processo de ocupação do espaço na informalidade habitacional no bairro de Jamaica, na cidade da Praia, em Cabo Verde. Através da observação direta, adentramos os espaços físicos e simbólicos de Jamaica, participamos do cotidiano deste contexto que permitiu nos familiarizarmos com determinados cenários de ocupação do espaço, assim como com a informalidade no meio social. As pessoas que moram no bairro conversam, interagem, trocam ideias e dão risadas, estabelecendo um tipo de relação social que dispensa as formalidades que em outros contextos, ou outro tipo de contatos e modos de entrevistar, seriam quase impossíveis.

Durante as incursões no bairro da Jamaica, realizamos entrevista e diálogos informais com seis interlocutores(as), dentre os quais estão os fundadores da Jamaica. O encontro e a convivência com os moradores do bairro constituíram momentos privilegiados, nos quais eles(as) puderam partilhar o sentido e os significados das suas experiências de ocupação do espaço e a construção da habitação na periferia da cidade da Praia. Foi uma oportunidade em que puderam formular e partilhar os modos pelos quais atribuem, respeitando as suas vivências, experiências culturais e resistências dentro do bairro. 
Das narrativas expressas, podemos captar que a ocupação do espaço na informalidade habitacional em Cabo Verde constitui uma das formas mais imediatas de obtenção de moradia própria para as pessoas de baixa renda. $\mathrm{Na}$ invenção e criação de estratégias alternativas de obtenção de casa própria fazem parte as práticas de manutenção de si e de seus agregados familiares. A construção de moradia no bairro surgiu como alternativa mais viável, seja pelo acesso ao terreno, seja por ser uma forma mais imediata para o acesso à casa própria. É notável o drama da falta de condições econômicas para o acesso ou a compra do terreno socialmente desejável. Essa narrativa traz a reflexão sobre o urbanismo no continente africano, caracterizado pelos princípios de sistema cultural, como a coletividade, $u b u n t u$, solidariedade e comunidade, unidade, restituição, importância da natureza, entre outros. É fundamental a compreensão do solo urbano como um bem coletivo. As práticas africanas de solo coletivo são ainda muito presentes nos modus vivendis africano, como é o caso da cidade da Praia, em Cabo Verde. No bairro de Jamaica, a maioria dos nossos interlocutores teve acesso ao terreno através de apoios dos(as) amigos(as), solidariedades e partilha. $\mathrm{Na}$ ausência de condições condizentes com o perfil exigido para a compra de terreno em bairros urbanizados, a construção da casa própria em Jamaica representa uma estratégia fundamental para as pessoas de baixa renda. Este fato é recorrente nas histórias de vida da maioria dos nossos interlocutores, pois, a construção de suas casas, implicou verdadeiramente numa escolha deliberada.

Uma das nossas interlocutoras fez a seguinte afirmação: "minha família sempre foi pobre, nunca tivemos terras para agriculturas. Gente preta como nós tem que lutar para sobreviver no campo. A vida nunca foi fácil para gente”. Ainda que de modo implícito, essa narrativa coloca a questão étnico-racial na estruturação da trama de relações sociais na cidade da Praia, e relaciona a relevância social existente entre as dimensões sócio-ocupacionais (espacial) do espaço urbano na informalidade habitacional. Ademais, a narrativa evidencia os desafios que historicamente se colocam ao povo africano, na resistência no acesso à casa próprio e ao direito à cidade, no contexto social atravessado pelo processo de colonização e racismo estrutural.

Os dados empíricos trazem à tona o protagonismo social das mulheres cabo-verdiana. Nesse caso, na configuração e formação da cidade da Praia, pois, assim como Dona Antônia, Dona Nilda, mesmo sendo casada, geriu todo o processo de construção de moradia no bairro de Jamaica, aliado a outras responsabilidades como a educação dos filhos e o trabalho doméstico, para complementar a renda familiar. Historicamente, a mulher cabo-verdiana tem tido um papel social de destaque, no contexto de Cabo Verde. Esse protagonismo da mulher africana está expresso na obra de Cheik Anta Diop (1989), que explicita historicamente a matrilinearidade das sociedades africanas.

Outro fator importante que se evidencia nas narrativas do nosso personagem Rasta, sobre o seu percurso de vida e trajetórias ocupacionais, diz respeito ao fato de que o aceso ao terreno, no bairro de Jamaica, foi capaz de mobilizar saberes adquiridos em outros momentos ou circunstâncias de suas vidas, seja no que tange à construção de casas, seja no que se refere às tradições da família. Conforme Gabriel Buchu, para construir a sua casa, seguiu as técnicas de construção de habitação que se usava no Senegal. São saberes ancestrais adquiridos com os avós e pais, que tinham profundo conhecimento das técnicas de construção de habitações ecológicas, (considerando o cuidado e respeito pela natureza) que também são usadas, principalmente no interior das ilhas de Cabo Verde.

Os princípios de coletividade, união, e solidariedades emanam nas práticas de construção de habitação, relacionados à sua trajetória de vida em Jamaica e são também partilhados em outras formas de relações sociais, sobretudo nas diferentes instâncias de socialização. O nosso interlocutor confirma alguns princípios do sistema cultural africano como comunidade, sociabilidade e irmandade, afirmando que "o lugar onde trabalho é também minha comunidade e as pessoas são minhas famílias. Morar em Jamaica é estar na minha comunidade com as minhas famílias", sintetiza ele, se referindo a esse aspecto. Podemos inferir de tudo isso os valores e práticas civilizatórias africanas, presentes na ocupação do espaço na informalidade habitacional, na cidade da Praia. Esse é um dos aportes a serem considerados na interpretação dos conflitos urbanos na cidade da Praia, caracterizada por assimetrias entre a resistência do povo africano em preservar a identidade cultural, e pela luta das instituições de matriz colonial para imprimir nas novas formas de habitar o lugar, um espírito mais moderno de cidade, desde os materiais que se utilizam, ao modo como isto ocorre. 


\section{Trajetos e Percurso na Ocupação do Espaço Urbano}

A partir de uma análise comparativa, envolvendo seis histórias de vida, observamos que a migração para a cidade da Praia constitui a estratégia para procurar outras oportunidades de vida e acesso à moradia. Todos se encontram, neste momento, com a moradia própria em Jamaica. Ainda assim, apesar dos elementos comuns às experiências de vida, é possível constatar diferenças específicas em suas trajetórias, que não podem ser desconsiderados nesse processo interpretativo. $\mathrm{O}$ nosso primeiro interlocutor e fundador do bairro de Jamaica apresenta uma longa história de permanência na cidade da Praia. Ele trabalhou no mercado de Sucupira (o maior centro comercial do país, situado na cidade da Praia), nas construções de habitações, pelos bairros da cidade, no aeroporto e, na altura da realização da pesquisa, ele trabalhava em uma empresa de comunicação. Enquanto Dona Antônia permanece na mesma condição de mulher, doméstica por vários anos, sem obter avanços e mudanças na sua casa, Rasta conseguiu construir duas casas para as suas duas esposas: "tenho duas famílias para cuidar, por isso tenho que me esforçar para oferecer uma casa condignas para elas".

Entretanto, percebemos que as razões para a ocupação do espaço nas áreas não urbanizados da cidade justificam-se, simultaneamente, por fatores inerentes ao percurso de cada um(a) e de uma circunstância social mais ampla. Ou seja, não obstante as trajetórias de vidas analisadas apresentarem aspetos comuns, como a migração do interior e das ilhas periféricas, origem social humilde, entrada precoce no mercado de trabalho ou abandono escolar, cada um(a) dos(as) nossos(as) personagens possui um percurso de vida único. Entretanto, a diferença nesses percursos é que determina as condições de habitação, melhorias ou estagnação na construção.

A diferença nas condições de casas construídas, pelos(as) moradores(as) de baixa renda na cidade de Praia é outra questão importante que vale destacar. Elas variam, dependendo do tipo e da qualidade de material a que tiveram acesso, das condições econômicas, famílias e amigos. Por outro lado, verificamos também que a qualidade e as características das moradias variam de acordo com algumas categorias, como a idade e as responsabilidades familiares, o número de filhos, a chefia familiar, os números de dependentes e agregados familiares, bem como as parcerias nas despesas do lar.
Nesse sentido, os rendimentos de alguns desses moradores(as), por exemplo, permitem a eles(as) ir mais longe e melhorar as qualidades de suas moradias, assim como ter acesso aos serviços básicos, como a energia elétrica, fazendo com que almejem, acima de tudo, a reprodução social de suas famílias e o alcance de outros bens, como por exemplo, comprar um carro. Os investimentos na educação e formação superior dos(as) filhos(as), a ampliação de moradia com a construção na vertical, acesso aos aparelhos de tecnologia, como a televisão, implementar negócios no bairro, são indicadores disso. Nas narrativas dos(as) nossos(as) personagens, fica presente esse desejo de ir além da satisfação do acesso à moradia própria. Identificar as experiências de Rasta, Buchu e Dona Nilda, e dos(as) moradores(as) de Jamaica com boas casas, leva-nos a refletir sobre as estratégias de resistência do povo africano face ao sistema de dominação hegemônica, excludente da sua essência e materialistas e segregacionista na sua origem, as casas informais muitas vezes rotulados de clandestinas, pobres e precarizadas, reagem às contingências do mundo cotidiano.

Reportando-nos aos conceitos de informalidade e precariedade das habitações, não percebemos que informalidade como sinônimo de marginalidade, exclusão social, ou pobreza. Na cidade da Praia, a informalidade habitacional pode também ser uma estratégia bem-sucedida de obtenção da casa própria. Aqui as culturas africanas, heterogêneas na sua composição, transportam conhecimentos milenares, ricos e complexos, transmitidos de geração a geração, ressignificados. Os moradores apresentam como grande motivação para a construção de habitação no espaço não urbanizado o fato de garantir o acesso à casa própria. Ao mesmo tempo, os obstáculos que as(os) moradoras(es) encontram no dia a dia influenciam as representações que elas fazem do bairro no qual vivem e de suas casas. Casa própria é a grande motivação para suportar os desafios e as vicissitudes encontradas no bairro de Jamaica, na cidade da Praia.

Entretanto, a perspectiva de análise apresentada não é consensual entre os estudos sobre o tema. Para alguns pesquisadores, dentre eles Tavares (2006) e Nascimento (2009), existem aspectos ambivalentes da ocupação do espaço na informalidade, na medida em que morar nesses bairros informais pode ser uma condição social tanto provisória como definitiva. Tavares (2006) defende que essas condições sociais tornam permanentes as circunstâncias em que alguns(as) 
moradores(as) encontram-se inseridos(as) no mercado de trabalho, num contexto de desregulamentação e flexibilidade, principalmente para os(as) moradores(as) mais novos(as), e mais escolarizados(as). Desse modo, a ocupação do espaço na informalidade configura-se como a única alternativa plausível para assegurar a casa própria e melhorar as condições de vida, sem o compromisso como o pagamento de aluguel. Por outro lado, as incertezas e as instabilidades no acesso ao espaço para construir habitação; e a esperança de ter casa própria fazem com que as pessoas de baixa renda construam as suas casas como provisórias.

Perante essas situações, as pessoas expostas a constrangimentos de diversas origens, longe de se comportarem como puros reflexos deles, possuem capacidades de invenção suficiente para modificar e transformar os determinismos estruturais que os cercam (CUNHA JÚNIOR, 2015). Para Henrique Cunha Júnior (2015), as pessoas de baixa renda agem livremente dentro das circunstâncias impostas pelas suas condições sociais, históricas e culturais. Tais ações, não são simples reprodução, mas traduzem antes um sentido prático pelo qual as pessoas agem, escolhendo livremente entre alternativas, dentro dos limites impostos pela circunstancias. Entretanto, as(os) moradoras(es) buscam influir também na produção de uma nova imagem, mais positivada e menos estigmatizada para a sociedade mais ampla, sendo que o bairro de Jamaica é um lugar diversificado, heterogêneo composto por distintos grupos sociais. Trata-se de um lugar com moradores e pessoas dignas, trabalhadores e famílias decentes. E, desse modo, procuram se afastar de outra imagem como costumam ser representados os locais mais pobres, quando homogeneizados e identificados apenas como espaços de concentração de pobreza, criminalidades e violência urbana e, deste modo, territorialmente estigmatizados.

As relações do trabalho existentes entre os moradores da periferia em Jamaica indicam que as necessidades habitacionais dos personagens entrevistados resultam do fato de grande parte desses agentes se encontrarem fora do mercado de trabalho, embora desenvolvam, frequentemente, atividades de pequeno comércio na residência. Essas referências às relações de trabalho podem dar conta da fragilidade da situação econômica que predomina nessa população, condicionando o acesso à moradia e também ao processo de consumo que caracteriza a reprodução cotidiana. Portanto, existem fatores que agem conjuntamente, provocando a fragmentação dos laços comunitários, se admitirmos a existência de correlação entre a vida de trabalho e a vida social através do estudo das práticas sociais que podem influir na constituição de um espaço, atribuindo ou não as particularidades a um bairro - maior ou menos funcionalidade das redes de vizinhança.

A pesquisa mostra-nos que o bairro de Jamaica é atravessado pelo fenômeno de desemprego, o qual tende a provocar uma erosão dos sistemas de apoio e proteção que incidem nas redes de relação sociais, de reciprocidade e ajuda mútua que emergiam entre os moradores, como mecanismo de amenização da escassez de salário. Elas se referem a desemprego, mas nem sempre representam a causa das mudanças na função de proteção social exercidas tradicionalmente pelas famílias - e a sua inserção na comunidade ou vizinhança. As redes de reciprocidade alimentam as expectativas de recebimento de bens e serviços e de retribuí-los, o que exige custos materiais, tempo, dedicação e disponibilidade, trazendo dificuldade de retribuição em situação de pobreza, e causando rupturas nas redes de vizinhança.

Essas redes se manifestam em plano interfamiliar, no qual as relações de confiança são atribuídas a vizinhos e amigos, envolvendo distintos graus de reciprocidade e interação entre as unidades residenciais, nas situações em que compartilham relações familiares. Entre os moradores, as relações primárias contemplam diferentes formas de vínculo para a obtenção de recursos não monetários, envolvendo o intercâmbio de favores e serviços dos mais diversos, como o cuidado dos filhos, ou monetários, como empréstimo financeiro. $\mathrm{O}$ acesso ao serviço também indica que as características dos ciclos de periferização e os seus moradores se refletem nos aspectos da dinâmica urbana como um conjunto no qual o acesso à cidade é visto a partir do seu papel de consumo - sistemas de saúde, transportes, abastecimentos de água, saneamento, educação, entre outros - percebendo-se que a sua organização tende à descentralização, o que contribuiria para uma gradativa substituição da busca de favores entre vizinhos. Deste modo, do ponto de vista interfamiliar, residir no bairro de Jamaica levou os moradores ao afastamento das famílias de origem, residentes no meio rural ou bairro distante, e à convivência com situações de fragilização da rede familiar como âmbito de exercícios da solidariedade.

Os moradores pobres situados próximos do centro também experimentam mudanças nas formas de convivência, que são percebidas de forma sutil através 
dos estereótipos atribuídos aos moradores dos bairros considerados "clandestinos", problemas decorrentes do "efeito do lugar", como um taxista que se recusa a levar os passageiros, entre outras situações. Os jovens demonstram que esses desafios apenas tendem a ser superados através das participações em instituições existentes, ou introduzidas no bairro, possibilitando uma ressignificação de práticas comunitárias.

\section{Cidades Africanas: a Cidade Abrindo Caminhos e Mobilizando} Saberes Milenares

Conforme as trajetórias de nossos interlocutores(as), o caminho percorrido para se estabelecer no trabalho, em um primeiro instante, decorre em sintonia com o saber fazer, aprendido no Senegal com todos os interlocutores. Conforme o nosso interlocutor nos explicou, a cidade se erguia e se espraiava em diferentes direções, e o pulsante setor de construção civil recrutava a mão de obra jovem e ansiosa por trabalho. As dinâmicas de ocupação quanto às relações sociais, forjadas em Jamaica, aproximam-se tanto do que se refere a estratégias adotadas na construção e manutenção de habitação e nas práticas coletivas de sobrevivências, quanto da constituição, ampliação e/ou dissolução das redes familiares e amizades, o que observamos em diferentes oportunidades. Efetivamente, a ocupação do bairro de Jamaica, à semelhança dos vários bairros da cidade da Praia, só foi possível graças a conhecimentos na construção de casas de madeira, barracos e blocos de concretos, tão comuns entre os moradores do interior da ilha de Santiago e das ilhas periféricas que migraram para a cidade. As pessoas que, no início de 2003, começaram a construção de casas no bairro moravam em Achada Grande Frente, com todas as limitações de emprego e oportunidade no mercado de trabalho.

Conquistar um espaço para construir moradia significa para muitas(os) moradoras(es) uma fase que representa a melhoria na vida e dignidade. As experiências da Dona Antônia e da Dona Nilda, assim como outras(os) moradoras(es) dos bairros pobres como Jamaica, mostram a trajetória percorrida por elas(es), além das redes e relações comunitárias estabelecidas através delas, até construírem as suas habitações. Um aspecto evidenciado nas entrevistas e conversas que aparecem em outras experiências analisadas refere-se aos programas de apoio a jovens e crianças nos bairros da periferia da cidade da Praia e que determinam significativamente o rumo que eles seguem no futuro.

O percurso de migrantes, que tiveram de atravessar fronteiras marítimas e terrestres para alcançar a cidade, seus percursos na cidade, independentemente de terem trazido-as suas famílias, as experiências dos seus filhos, netos e até vizinhos para recomporem as suas redes sociais, além das estratégias socioculturais de inserção na cidade. A experiência do campo mostrou-nos que, diferentemente do que imaginávamos inicialmente, no bairro de Jamaica existem pessoas oriundas de várias comunidades do interior da ilha de Santiago, assim como das ilhas periféricas, como Maio e Fogo, e, em menor escala, de países como Senegal e Guiné-Bissau, que faziam incidir sobre os bairros da cidade da Praia, de maneira geral, marcas importantes em sua constituição.

Deste modo, no contexto da África contemporânea, atravessado pelas práticas e dinâmica civilizatória europeia, reproduzidas pelos Estados africanos e Organizações não Governamentais, a "periferia urbana" é resultado de um processo que constitui uma relação de poder. Nesse sentido, o território é concebido, segundo Milton Santos (1988), como uma estrutura múltipla, complexa e diversa, considerando a sua estrutura histórica e social, partilhado de apropriação, transmissão social e cultural. O espaço urbano nos países africanos de influência colonial, sua organização - centralidade e periferia - relações e práticas, sociais e culturais, são o reflexo do processo de demarcação do território, que se traduz em formas, comportamentos, estigmas e identificações sociais e simbólicas no espaço. O território de um grupo social transcende à espacialidade delimitada em marcos geográficos. Trata-se de lugar onde o grupo constrói a sua relação cotidiana de apoios, trocas e pertencimento a um espaço, a uma coletividade.

Para Milton Santos (IDEM), o território é o processo que envolve, ao mesmo tempo, a dimensão simbólica e cultural, por meio de uma identidade territorial atribuída a um grupo social como forma de controle simbólico sobre o espaço onde vive, sendo também uma forma de apropriação e uma dimensão mais concreta do caráter político e disciplinar. É a apropriação e ordenação do espaço, como forma de domínio e disciplinarização do espaço (SANTOS, 1988). Existem diferentes formas de ocupação e reprodução do espaço dentro da cidade. O vivido como lugar com o qual as pessoas se identificavam; os processos históricos e sociais, de apropriação e deslocamentos do espaço vivenciados pelo grupo, nos deslocamentos 
para diferentes bairros; e a forma como os grupos constroem o território e seu pertencimento. Assim, Santos (1980) assegura a importância do espaço urbano não só como paisagem geográfica, mas, sobretudo, enquanto um construto social, como produtor e produto de diferentes modos de vida.

Apesar de contribuírem para a formação da cidade, a trajetória histórica da formação e crescimento bairro foi trilhada em recorrentes envolvimentos e confrontos com os poderes públicos. Na tentativa de organização espacial da antiga cidade, as pessoas de baixa renda que construíram as suas casas no bairro repetidamente são acusadas de contribuir para "enfeiar" a cidade ou colaborar para a permanência de hábitos considerados "incivilizados", que travavam o advento da modernidade. A concepção de modernidade, assim como a visão de urbanidade que orientaram os seus projetos de modernização, considerava o abandono das tradições, centradas no modelo civilizatório africano, como imprescindível para as cidades africanas.

As descrições trazidas a partir dos(as) nossos(as) entrevistados(as) ressaltaram a história social atual da ocupação do espaço na informalidade habitacional no bairro da Jamaica, na cidade da Praia, em Cabo Verde. A partir delas, demonstramos empiricamente como esses espaços mesclam práticas de ocupação de espaço na informalidade habitacional, ligadas aos novos hábitos de produção de espaço como tendências globais da cultura ocidental hegemônica. Como o são a ocupação de espaço com outros materiais, como os blocos de concreto, portas de alumínio, modelos americanos, construção horizontal, e como usos de materiais referentes a tradições culturais africanas que buscam seus recursos simbólicos centrados nos princípios estruturantes do sistema cultural africano.

Outro elemento que merece ser destacado é o fato de que a construção de moradias na informalidade habitacional mobiliza conhecimentos e saberes adquiridos em outros momentos de seus percursos de vida, sejam eles de caráter ocupacional ou de tradição familiar. Como observado através das narrativas de Buchu, para construir a sua moradia, este recorreu às experiências e aprendizados de construção de moradias adquiridos com os seus ancestrais ainda no Senegal. A partir dessas evidências, defendemos que esses agentes, quando necessário, mobilizam saberes e valores culturais adquiridos dentro do grupo de pertença, experiências herdadas de conhecimentos ancestrais, potencializando-os como estratégias para o acesso a moradias. Isso demonstra que essas pessoas têm conseguido converter o conjunto de roteiro de saberes, valores e competências em favor criativo e capacidade de intervenção.

A necessidade de habitação, não correspondida pela promoção legal e a perspectiva de melhorar as condições de habitabilidade, levam a população a recorrer ao loteamento ilegal e espontâneo. Infringindo as normas urbanísticas, os residentes constroem as habitações na medida das suas capacidades financeiras e de acordo com o modelo por si idealizado. Esse recurso ao setor espontâneo/informal de solos não pode ser visto à margem do processo de atribuição de terrenos pelo poder público. O principal desafio do urbanismo africano na atualidade, que leve em conta e parta deste paradigma da afrocentricidade, é o de produzir cidades que representem e respeitem a diversidade étnica de todos os membros destas nações e assumam os compromissos políticos de realmente conseguir apresentar os interesses dos mais variados grupos. Outro elemento importante, é a preocupação com os espaços de feiras e mercados. Esses espaços representam, de um lado, uma âncora na tradição e, de outro, o da produção de oportunidades de trabalho e de integração entre os negócios das populações rurais e urbanas.

As práticas de ocupações do espaço urbano na informalidade habitacional tiveramimportância em épocas anteriores, com um peso social significativo no processo de configuração da sociedade cabo-verdiana. Apesar disso, foram combatidas pelas políticas higiênico-sanitárias de urbanização e organização da municipalidade e pelas políticas de indústria imobiliária, configuradas em modelos ocidentais modernos, marcados pelo neoliberalismo econômico, pela competitividade e pela segregação espacial. E com consequências nefastas no aprofundamento das desigualdades sociais, na marginalização das pessoas de baixa renda e na configuração da pobreza e miséria que afetam as populações das periferias urbanas.

\section{Considerações Finais}

Em jeito de conclusão, através de estratégias de resistência forjadas em contextos de extremas desigualdades nas relações de poder, as cidades africanas mesclam práticas de ocupações urbanas na informalidade habitacional, congregam práticas resultantes das experiências históricas e culturas africanas. Muitas dessas 
estratégias não são tão novas, reinventadas nas práticas e experiências cotidianas dos moradores, o que abre a possibilidade para uma constante coabitabilidade de saberes, experiências e técnicas ancestrais africanas com a de novos hábitos e práticas culturais urbanos ocidentais, impostos pelo poder público. Contudo, quisemos enfatizar e iluminar algumas das profundas assimetrias existentes entre as categorias sociais urbanas. Aquelas que marcam o grande contraste e oposição entre o modo de habitar e viver da elite e o das pessoas de baixa renda, enquanto produtos e reproduções do capitalismo, num continente ainda marcado pelo racismo estrutural, colonialismo e da globalização hegemônica. Entendemos que, no contexto africano, tais problemas podem ser melhor equacionados a partir da consideração das experiências e de uma maior valorização do sistema cultural africano, tomando africanas(os) como sujeitos históricos, agentes e protagonistas da sua própria existência.

\section{Referências}

AGUESSY, Honorat. Visões e percepções tradicionais. In: SOW, Alpha et.al, Introdução a Cultura Africana. Lisboa: Edições 70, 1980. p.95-136.

ANDRADE, Rutte. Diálogos encruzilhados: afrocentricidade, mulherismo africana, e possibilidades epistemológicas emancipatórias. In: COSTA, Geranilde; OLIVEIRA, Evaldo Ribeiro (Org.). Experiências em Ensino, Pesquisa e Extensão na Unilab: Caminhos e Perspectiva. v. 3. Fortaleza: Imprece, 2018.

ASANTE, Molefi Kete. Afrocentricidade: notas sobre uma posição disciplina. In: NASCIMENTO Elisa L. (Org.). Afrocentricidade. Uma abordagem epistemológica Inovadora. São Paulo: Selo Negro, 2009, p. 93-110.

CUNHA JUNIOR, Henrique. Africanidade e Afrodescendência. Notas de aula da disciplina de pós-graduação. Fortaleza-CE, 2015.

DIOP, Cheikh Anta. Civilisation ou Barbarie. Paris: Présence africaine, 1981.

FANON, Frantz. Os Condenados da Terra. Juiz de Fora:UFJF, 2006.

NASCIMENTO, Judite Medina do. N. O crescimento urbano e a estrutura funcional da cidade da Praia. 2003. Dissertação (Mestrado em Geografia Humana) - Faculdade de Letras, Universidade de Lisboa, Lisboa, 2003.

La croissance et le Système de Gestion et de Planification de laVille de Praia (Rep. Du Cap-Vert). 2009. Thèse (Doctorat) - Département de Géographie, Faculté de Lettres et Sciences Humaines, Université de Rouen, Rouen, 2009. 358p.

OBENGA, Theóphile. La philosophie africaine de la période pharaonique. Paris: L'Harmattan, 1990. OYEWUMI, OYERONKE. The invention of women: making an African sense of Western gender discourses. Minneapolis, MN: University of Minnesota Press, 1997.
PERLMAN, Janice. Marginality from Myth to Reality. In: PERLMAN, Janice. Favela: four decades of living on the edge. New York: Oxford University Press, 2010a.

The Mystery of Mobility. In: PERLMAN, Janice. Favela: four decades of living on the edge. New York: Oxford University Press, 2010b.

RODNEY, Walter. How Europe Underdeveloped Africa. London: Bogle-L'Ouverture Publications, 1972.

SANTOS, Milton. A cidade nos países subdesenvolvidos. Rio de Janeiro: Civilização Brasileira, 1965.

SANTOS, Milton. Metamorfoses do espaço habitado. São Paulo: Hucitec, 1988.

SANTOS, Milton. Sociedade e espaço: a formação social como teoria e como método. Boletim Paulista de Geografia, São Paulo, n.54, 1977.

SEMEDO, José Maria. Um arquipélago do Sahel. In: Arquivo Histórico Nacional de Cabo Verde. Descobertas das Ilhas de Cabo Verde. AHN PRAIA-SÉPIA PARIS, 1998.

TAVARES, C. A política de solos na política urbana: a sua relevância para a cidade da Praia Cabo Verde. 2006. Dissertação (Mestrado em Gestão do Território) - Faculdade de Ciências Sociais e Humanas, Universidade Nova, Lisboa, 2006.

ZALUAR, Alba. Integração perversa: pobreza e tráfico de drogas. Rio de Janeiro: FGV, 2004. 
SOBRE AS AUTORAS E OS AUTORES

\section{Alejandro De Oto}

Investigador de Consejo Nacional de Investigaciones Científicas y Técnicas (CONICET) y profesor en la Universidad Nacional de San Juan (UNSJ), Argentina.

E-mail: adeoto@gmail.com

\section{Alcione Correa Alves}

Mestrado e Doutorado em Letras, obtidos pela Universidade Federal do Rio Grande do Sul. Está professor adjunto III na Universidade Federal do Piauí, onde tem desenvolvido atividades docentes de ensino, extensão e pesquisa, em níveis de graduação e pós-graduação. Tem coordenado, desde 2010, o Projeto de Pesquisa Teseu, o labirinto e seu nome, dedicado ao tema das construções identitárias nas literaturas negras americanas. Isso implica, como atual objetivo de investigação (seu e do Projeto Teseu), perceber este corpus de pensamento negro em uma dupla dimensão de ficção e ensaio, de modo a evidenciar o quanto contribui à formulação de novos problemas, teóricos e epistemológicos, atinentes a uma Teoria Literária contemporânea em Nuestramérica (Abya Yalá).

E-mail: alcione@ufpi.edu.br

\section{Aline de Moura Rodrigues}

Estudante do Bacharelado em Ciências Sociais na Universidade Federal do Rio Grande do Sul. Atualmente Bolsista de Desenvolvimento Acadêmico por meio do Programa de Desenvolvimento Acadêmico Abdias do Nascimento (SECADI/CAPES), na condição de estudante-hóspede no Centro de Investigaciones Superiores en Antropología Social (Unidad CIESAS Sureste - San Cristóbal de Las Casas, México).

E-mail: linymourar@gmail.com

\section{Andréa Franco Lima e Silva}

Doutoranda do Programa de Pós-Graduação em Sociologia (UFPB) Mestre em Sociologia (UFMG), Graduação em Ciências Sociais (UFMG). E-mail: andreafls@gmail.com

\section{Deivison Faustino}

Professor Associado da Universidade Federal de São Paulo (UNIFESP) e integrante do Instituto Amma Psique e Negritude.

E-mail: deivison.faustino@unifesp.br

Página: http://deivisonnkosi.kilombagem.net.br

\section{Dyana Helena de Souza}

Bacharel em Serviço Social pela Universidade de Brasília (UnB). Bacharel em Saúde Coletiva pela Universidade de Brasília (UnB). Mestranda do Programa de Pós-Graduação em Saúde Coletiva pela Universidade de Brasilia (UnB). Integrante Grupo de Pesquisa Promoção e Equidade em Saúde, realizando estudos sobre a inserção da equidade racial na formação profissional nos cursos da área de saúde.

E-mail: dyana_4521@hotmail.com

\section{Fernanda Maiato}

Graduanda em Psicologia pela Universidade Federal do Rio Grande do Sul (UFRGS). Integrante do Coletivo Psicopreta.

E-mail: fernandamaiato.ch@gmail.com

\section{Jefferson Olivatto da Silva}

Professor Depto. Psicologia Social e Institucional (UEL), Programa de Pós-Graduação em Educação (UNICENTRO). Pós-doutor em História (UFPR), Pós-doutor em Educação (UFPR), Pós-doutorando em Serviço Social e Política Pública (UEL). Doutor em Ciências Sociais (UNESP/ Marília). Graduação em Filosofia (USC-Bauru) e Formação de Psicólogo (UNESP/Assis).

E-mail: jeffolivattosilva@uel.br 


\section{Károl Veiga Cabral}

Doutora em Antropologia pela Universitat de Rovira y Virgili. Pós Doutoranda pela Universidade Federal do Pará (UFPA).

E-mail: karolveigacabral@gmail.com

\section{Maíne Alves Prates}

Graduada em Psicologia pela Pontifícia Universidade Católica do Rio Grande do Sul (PUCRS). Mestranda no Programa de Pós-graduação em Psicologia Social e Institucional, Universidade Federal do Rio Grande do Sul (UFRGS).

E-mail: mainealvespratesn@gmail.com

\section{Márcia Denise de Lima Dias}

Suporte pedagógico da Secretaria Municipal de Educação de Mangueirinha/ PR. Mestre em Educação (UNICENTRO). Graduação em História (UNICENTRO/Guarapuava).

Email: mardias2020@gmail.com

\section{Marina Tremper}

Bacharel em Psicologia pela Universidade Federal de Pelotas (UFPel).

E-mail: marinatremper@gmail.com

\section{Míriam Cristiane Alves}

Doutora em Psicologia pela Pontifícia Universidade Católica do Rio Grande do Sul (PUCRS), Professora Adjunta do Curso de Psicologia da Universidade Federal de Pelotas (UFPel), Professora Colaboradora do Programa de Pós Graduação em Psicologia Social e Institucional da Universidade Federal do Rio Grande do Sul (UFRGS). Coordenadora do Núcleo de Estudos e Pesquisa É'LÉÉKO.

E-mail: oba.olorioba@gmail.com

\section{Mirian Teresa de Sá Leitão Martins}

Psicóloga e Mestre em Ciências Médicas PGCM/Uerj e Mestranda em Saúde Coletiva/UFF

E-mail: mirianteresad@yahoo.com.br

\section{Rafael Barcellos}

Graduando em Psicologia pela Universidade Federal do Rio Grande do Sul (UFRGS). Assistente em Administração na UFRGS. Pesquisador do Núcleo de Estudos e Pesquisa É'LÉÉKO. Integrante do Coletivo Psicopreta. E-mail: rafaelbarcellosp@gmail.com

\section{Rutte Tavares Cardoso Andrade}

Professora da Universidade da Integração Internacional da Lusofonia Afro-Brasileira (UNILAB). Colaboradora do Curso de Pós-Graduação em Pedagogia na Universidade de Santiago em Cabo Verde.

E-mail: rutteandrade@unilab.edu.br

\section{Tatiane Borchardt da Costa}

Graduada em Psicologia pela Universidade Federal de Pelotas (UFPel) Pesquisadora colaboradora do Núcleo de Estudos e Pesquisas É'LÉÉKO.

E-mail: tatianebdcpsi@gmail.com

\section{Thais Rodrigues dos Santos}

Psicóloga do Setor de Assistência Estudantil da Universidade Estadual do Centro-Oeste (UNICENTRO/Irati). Mestra em Educação (UNICENTRO). Graduação e Formação de Psicóloga (UNICENTRO/Irati).

E-mail: rodriguesdossantosthais@gmail.com 


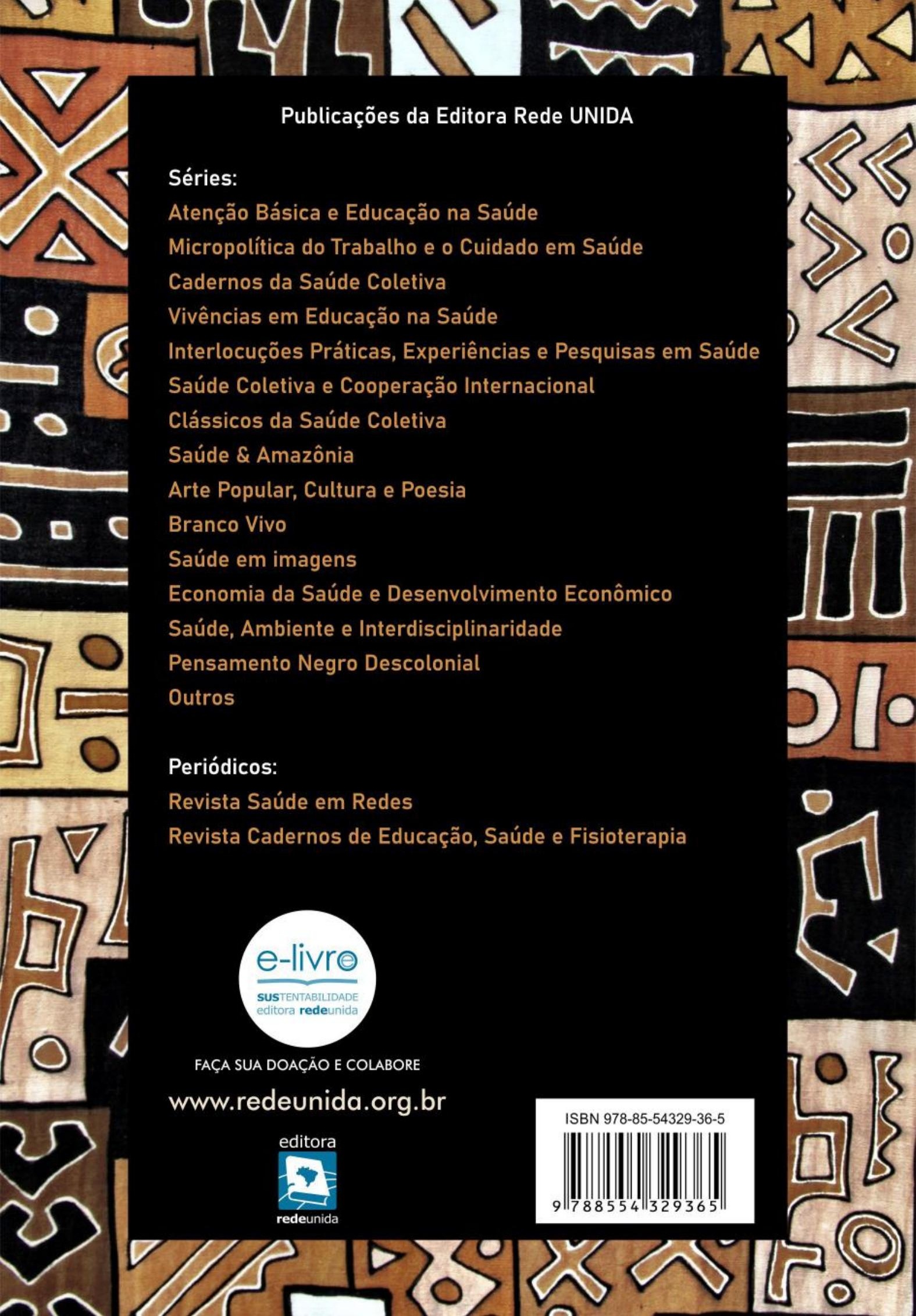

